UNIVERSIDADE DE SÃO PAULO

FACULDADE DE ECONOMIA ADMINISTRAÇÃO E CONTABILIDADE DE RIBEIRÃO PRETO DEPARTAMENTO DE ADMINISTRAÇÃO

PROGRAMA DE PÓS-GRADUAÇÃO EM ADMINISTRAÇÃO DE ORGANIZAÇÕES

LEONARDO AUGUSTO AMARAL TERRA

Dinâmica simbiótica: o problema estratégico visto sob a perspectiva da complexidade

Orientador: Prof. Dr. João Luiz Passador 
Prof. Dr. João Grandino Rodas

Reitor da Universidade de São Paulo

Prof. Dr. Rudinei Toneto Junior

Diretor da Faculdade de Economia, Administração e Contabilidade de Ribeirão Preto

Prof. Dr. André Lucirton Costa

Chefe do Departamento de Administração 


\section{DINÂMICA SIMBIÓTICA: O PROBLEMA ESTRATÉGICO VISTO SOB A PERSPECTIVA DA} COMPLEXIDADE

Versão corrigida da dissertação apresentada ao Programa de Pós- Graduação em Administração de Organizações da Faculdade de Economia, Administração e Contabilidade de Ribeirão Preto da Universidade de São Paulo, como requisito para obtenção do título de Mestre em Ciências obtido no Programa de Pós-Graduação em Administração de Organizações - Original disponível na FEARP.

Áreas de concentração: Estratégia e Desenvolvimento Organizacional.

Orientador: Prof. Dr. João Luiz Passador. 
AUTORIZO A REPRODUÇÃO E DIVULGAÇÃO TOTAL OU PARCIAL DESTE TRABALHO, POR QUALQUER MEIO CONVENCIONAL OU ELETRÔNICO, PARA FINS DE ESTUDO E PESQUISA, DESDE QUE CITADA A FONTE.

\section{FICHA CATALOGRÁFICA}

Faculdade de Economia Administração e Contabilidade de Ribeirão Preto

Terra, Leonardo Augusto Amaral

Dinâmica simbiótica: o problema estratégico visto sob a perspectiva da complexidade. / Leonardo Augusto Amaral Terra; orientador: João Luiz Passador. Ribeirão Preto, 2010.

190 p. : il. ; $30 \mathrm{~cm}$

Dissertação (Mestrado - Programa de Pós-Graduação em Administração de Organizações) - Universidade de São Paulo, 2010.

1. Estratégia; 2. Complexidade; 3. Acoplamentos; 4. Simbiose; 5. Sustentabilidade. 


\section{FOLHA DE APROVAÇÃO}

Leonardo Augusto Amaral Terra

Dinâmica simbiótica: o problema estratégico visto sob a perspectiva da complexidade

Versão corrigida da dissertação apresentada ao Programa de PósGraduação em Administração de Organizações da Faculdade de Economia, Administração e Contabilidade de Ribeirão Preto da Universidade de São Paulo, como requisito para obtenção do título de Mestre em Ciências obtido no Programa de Pós-Graduação em Administração de Organizações - Original disponível na FEARP.

Aprovado em:

BANCA EXAMINADORA

Prof. Dr.:

Instituição: Assinatura:

Prof. Dr.:

Instituição: Assinatura:

Prof. Dr.:

Instituição: Assinatura: 

Dedico este trabalho aos pioneiros do novo espírito científico, pelas batalhas que travaram para possibilitar uma nova compreensão acerca do mundo que nos cerca. 



\section{AGRADECIMENTOS}

Ao Professor Dr. João Luiz Passador pela orientação, pelas lições de vida, pela amizade e principalmente pelo apoio, quando decidi realizar meu esforço de pesquisa sobre uma temática pouco trivial dentro da Administração.

À minha mãe, Maria Cláudia Amaral Terra e ao meu pai José Tadeu Bichir Terra, por terem possibilitado minha formação e pela compreensão nesta fase tão intensa de minha vida.

À Fernanda Heloísa do Carmo pela compreensão quando eu não podia lhe dar a devida atenção, por demonstrar interesse quando eu falava sobre os assuntos envolvidos neste trabalho e pela ajuda imprescindível nos dias anteriores à conclusão do mesmo.

Aos professores Charbel José Chiappetta Jabbour e Gilberto Tadeu Shinyashiki, membros da banca de qualificação deste trabalho, pelas valiosas contribuições.

Aos meus colegas de mestrado que muito contribuíram e me motivaram com suas discussões e considerações a respeito desta obra, em especial ao amigo Christian Ganzert pelas conversas instigantes e pela disposição em ajudar com a indicação de literaturas que foram fundamentais para o desenvolvimento deste trabalho.

À professora Dra. Cláudia Souza Passador por me estimular a embarcar na aventura do mestrado.

À minha irmã, Fabíola Amaral Terra, pelo apoio dado durante a fase de qualificação.

Aos meus grandes amigos do NMC pela presença constante em minhas conquistas e momentos difíceis, em especial ao meu amigo Raoni Ciasca, pela ajuda na revisão do resumo em inglês deste trabalho.

Aos professores e funcionários da Universidade de São Paulo, sem os quais esta aventura não teria se constituído na maravilhosa experiência que se concretizou.

Às inúmeras bibliotecas e editoras ao redor do mundo que têm digitalizado e disponibilizado livremente o acesso a obras raras de seus acervos, promovendo a ampla divulgação do conhecimento. 

Às vezes, para enxergarmos mais longe, temos que olhar por cima dos muros que nos cercam.

Marcelo Gleiser, 2010 



\section{RESUMO}

TERRA, L. A. A. Dinâmica simbiótica: o problema estratégico visto sob a perspectiva da complexidade, 190 p. Dissertação (Mestrado) - Faculdade de Economia, Administração e Contabilidade de Ribeirão Preto, Universidade de São Paulo, Ribeirão Preto, 2010.

O cenário de grandes transformações do mundo atual fez com que autores consagrados, como C. K. Prahalad, Gary Hamel e Peter F. Drucker, reconhecessem que os modelos estratégicos vigentes estariam encontrando dificuldades para oferecer racionalidades adequadas para se lidar com o problema da mudança, nas sociedades e nas organizações de produção contemporâneas. Para parcela significativa da produção científica recente na área, a problemática em tela se deve, em grande medida, à fragmentação teórica e à especialização, decorrentes do uso intensivo de abordagens prescritivas nas Ciências Administrativas. Este cenário conduz à necessidade de se repensar os correntes arcabouços conceituais. Neste sentido, o presente esforço de pesquisa teve por objetivo desenvolver uma síntese dos aspectos internos e externos da dinâmica do problema estratégico, a partir de abordagens aderentes à teoria da Complexidade. Para tal, foi realizado um esforço de revisão conceitual, embasado em uma análise do problema, segundo a metodologia fenomenológica de Husserl. Os resultados foram submetidos a um procedimento analógico, realizado por meio de pesquisa bibliográfica em literaturas que tratam da complexidade em outros sistemas teóricos próprios, especialmente os da Biologia. Como resultado, identificou-se que as organizações são produto de acoplamentos entre dois ou mais sistemas distintos que, por sua vez, se acoplam ao sócio-sistema humano e estes, por sua vez, ao restante da dinâmica planetária. Em última análise, esta configuração nutre forte analogia com as dinâmicas baseadas na simbiose, encontradas nos estudos mais recentes da biologia que, ao que o estudo indica, podem se transformar em uma inspiradora, importante e útil analogia para o aperfeiçoamento dos arcabouços teóricos em gestão.

Palavras chave: 1. Estratégia; 2. Complexidade; 3. Acoplamentos; 4. Simbiose; 5. Sustentabilidade. 



\begin{abstract}
TERRA, L. A. A. Symbiotic dynamic: strategic problem seen from complexity perspective, 190 p. Master Degree Paper - School of Economics, Management and Accounting of Ribeirão Preto, University of São Paulo, Ribeirão Preto, 2010.
\end{abstract}

Major Changes in today's world has made renowned authors such as C. K. Prahalad, Gary Hamel and Peter F. Drucker recognized that the existing strategic models are not providing reasonable and adequate solutions to deal with the society changing problems and with the contemporary production organizations. For a significant portion of the recent scientific output in this area, the issue faced is due to, in most of it, the theoretical fragmentation and the specialization resulting from the intensive use of prescriptive approaches in Administrative Sciences. This scenario leads to the need of rethinking the current conceptual frameworks. This study, in particular, addresses the concepts related to the strategic problem of which we highlight the dynamics behind the problem, results of the aforementioned organizational changes that are characteristic of a contemporary society. For this, the present research effort aims to develop a summarized study of the internal and external aspects of dynamic strategic problems and, taking as a starting point the approaches inherent in the complexity theory. To achieve this, an effort was made to review the concept behind the problem analysis, according to Husserl's phenomenological methodology. The results were submitted to an analog procedure, bibliographical research on the literatures that deals with complexity in other theoretical systems, especially in biology. As a result, it was found that organizations are products of couplings between two or more separate systems, which will couple to the socio-human system, and these, to the rest of the planetary dynamics. As a last analysis, this configuration has strong analogy with the dynamics based on symbiosis, found in recent biology; this study suggests that it can become an inspiring, important and useful metaphor for the improvement of the theoretical frameworks in management.

Keywords: 1. Strategy; 2. Complexity; 3. Couplings; 4. Symbiosis; 5. Sustainability. 



\section{LISTA DE FIGURAS}

Figura 1-A inevitável transformação na indústria

Figura 2 - Sequência de apresentação dos capítulos e sua relação com os objetivos específicos do trabalho

Figura 3 - Dinâmica das interações dialéticas de Hegel.

Figura 4 - Laço de realimentação representando a pilotagem de um barco. 57

Figura 5 - Esquema básico da realimentação. 58

Figura 6 - Propriedades compartilhadas entre os níveis sistêmicos. 61

Figura 7 - Ciclo de apreensão do conhecimento segundo o pensamento sistêmico...... 62

Figura 8 - Dinâmica que origina as estratégias realizadas pela organização.......................... 71

Figura 9 - Estratégia como padrão e as implicações de seus extremos polares...................... 73

Figura 10 - Foco da estratégia como posição ou como perspectiva...................................... 76

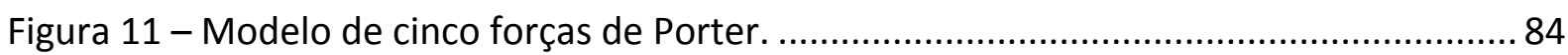

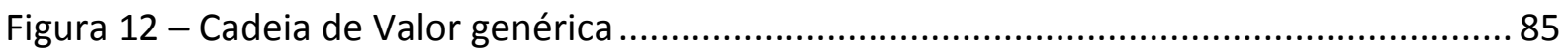

Figura 13 - A formação da estratégia como um único processo .......................................... 97

Figura 14 - Esboço da essência primeira do problema estratégico. ..................................... 110

Figura 15 - Dinâmica das interações para organizar a expressão dos conteúdos. ................ 117

Figura 16 - Rotas previstas para uma abordagemcom enfoque em pesos iguais (A) e para uma abordade com enfoque em pesos maiores para os dados mais recentes (B)....... 124

Figura 17 - Modelo básico para a cibernética e a teoria geral dos sistemas ....................... 125

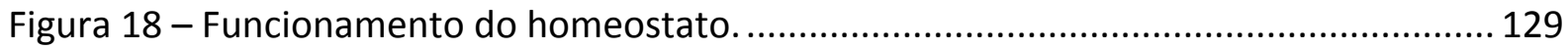

Figura 19 - Unidade autopoiética oriunda das reações sugeridas por Maturana................. 146

Figura 20 - Conversão da essência primeira de uma organização em um diagrama sintético

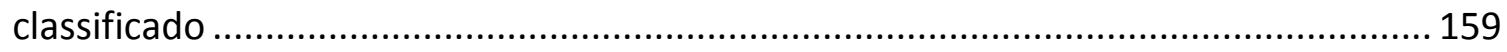

Figura 21 - Diagrama esquemático da dinâmica do problema estratégico......................... 166

Figura 22 - Laços de realimentação entre os sistemas externos e a estratégia das

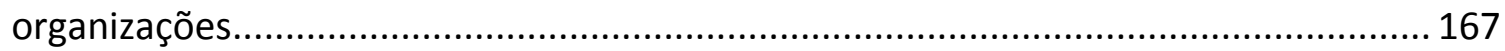

\section{LISTA DE QUADROS}

Quadro 1 - Critérios para reconhecer um sistema 55

Quadro 2 - Diferenças entre as abordagens do reducionismo cartesiano e do paradigma da complexidade 
Quadro 3 - Áreas de concordâncias acerca da estratégia

Quadro 4 - Escolas de pensamento estratégico propostas por Mintzberg, Ahlstrand e Lampel (1998)

Quadro 5 - Principais aspectos das dez escolas de pensamento estratégico, segundo Mintzberg, Ahlstrand e Lampel (1998) .95

Quadro 6 - Fundamentos epistemológicos da complexidade, adotados pelo presente esforço de pesquisa 103

Quadro 7 - Descrição dos componentes básicos de um sistema cibernético .124

Quadro 8-Mapeamento dos estados dados por transições de estado $x \rightarrow f(x)$ onde $f(x)=3 x$ 125

Quadro 9 - Principais características dos sistemas auto-organizantes .133

Quadro 10 - Princípios da Cibernética .134

Quadro 11 - Reação sugerida por Humberto R. Maturana para simular um sistema autopoiético .146

Quadro 12 - Variáveis do problema estratégico 168

\section{LISTA DE GRÁFICOS}

Gráfico 1 - Evolução de sistemas com e sem feedback, alimentados por uma entrada

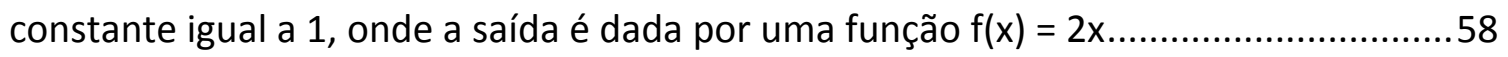

Gráfico 2 - Mapeamento do espaço de formação da estratégia. ...........................................96

Gráfico 3 - Escolha das trajetórias em um ponto de bifurcação ........................................139

Gráfico 4 - Bifurcações sucessivas em um sistema de não-equilíbrio..................................140

Gráfico 5 - Comparação atmosférica da Terra com seus dois vizinhos planetários..............154

\section{LISTA DE TABELAS}

Tabela 1 - Evolução de sistemas com e sem feedback, alimentados por uma entrada constante igual a 1 , onde a saída é dada por uma função $f(x)=2 x$. .58

Tabela 2 - Número de resultados retornados nas pesquisas realizadas nas bases de dados 


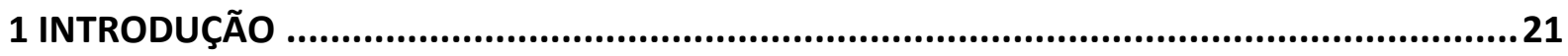

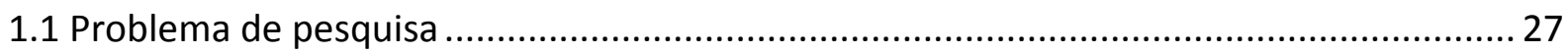

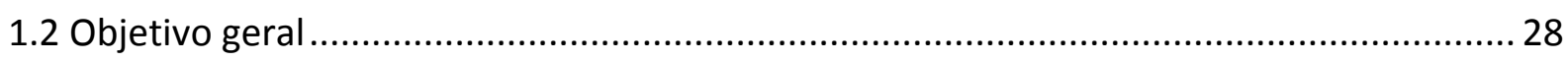

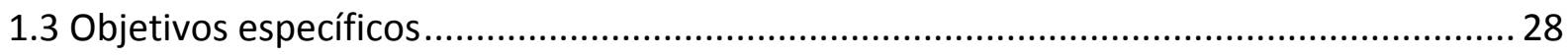

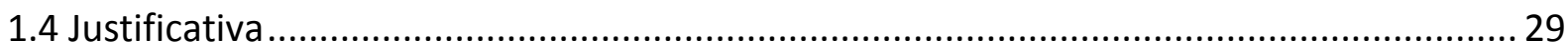

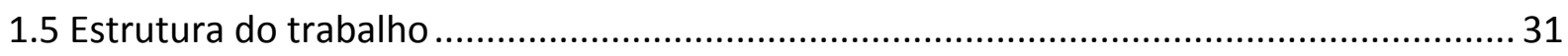

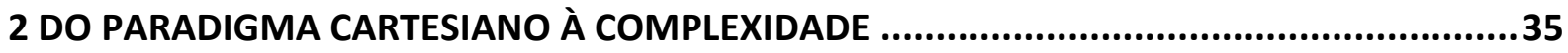

2.10 antigo embate entre a permanência e a mudança........................................................ 37

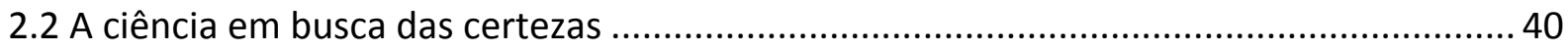

2.3 Os conflitos sociais como a manifestação de um mundo transitório................................. 43

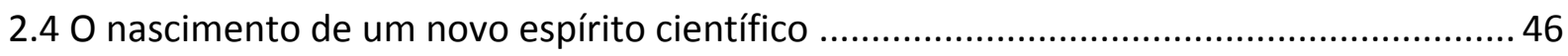

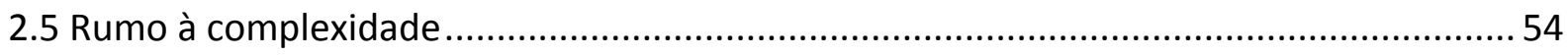

3 AS MÚLTIPLAS PERSPECTIVAS DA ESTRATÉGIA .....................................................67

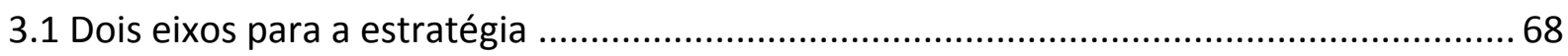

3.2 Mintzberg, Ahlstrand e Lampel e o processo estratégico .............................................. 78

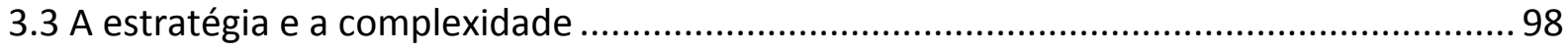

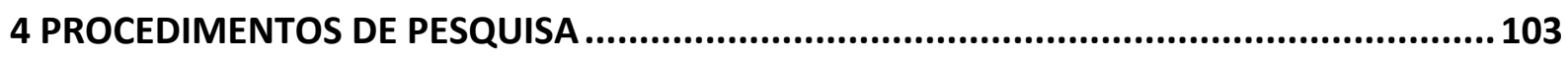

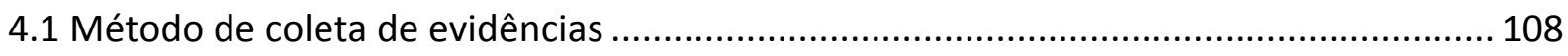

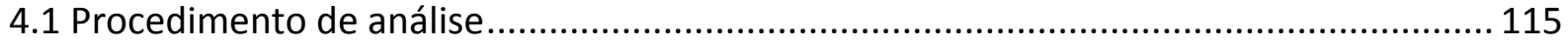

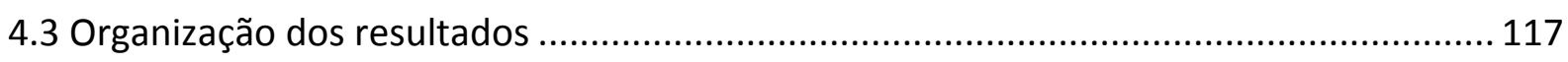

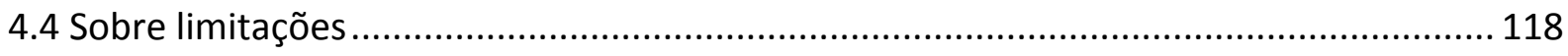

5 A DINÂMICA DOS ASPECTOS INTERNOS E EXTERNOS DA ORGANIZAÇÃO ...................... 121

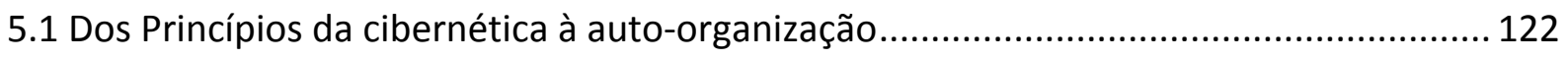

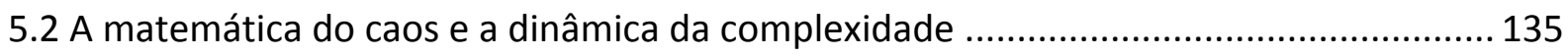

5.3 Máquinas produzidas pelo homem e máquinas vivas .............................................. 143

5.4 Simbiogênese: os acoplamentos dos sistemas vivos ................................................. 149

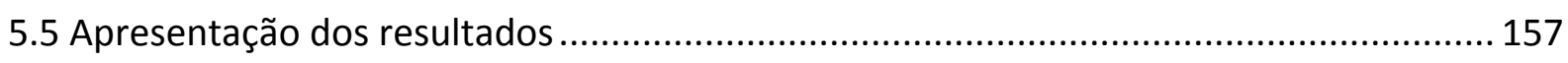

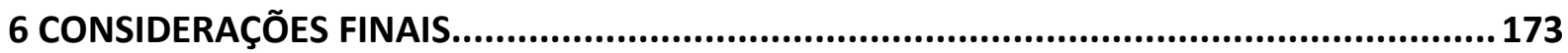

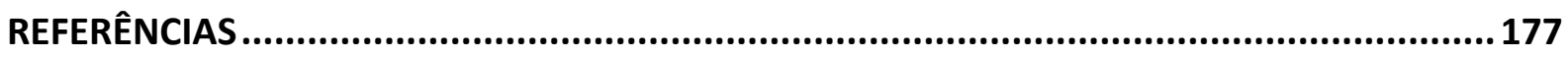





\section{INTRODUÇÃO}

Durante grande parte do século $X X$ as transformações naturais e sociais foram rotineiramente tratadas como parte de um grande fenômeno superficial, em um mundo essencialmente estável (CAPRA, 1983). Apesar dos avanços denunciadores que se desenvolviam nas ciências naturais, desde o início do século em questão, o interesse da ciência das organizações pelas tratativas baseadas em um universo regido pela instabilidade, só veio a ganhar força a partir da década de 1980. Drucker (2003) lembra que neste período as ações de grandes líderes mundiais como o presidente Estados Unidos da América Ronald Wilson Reagan, o secretário-geral do comitê central do partido comunista soviético Mikhail Serguéievich Gorbachev e a primeira ministra inglesa Margaret Hilda Thatcher, promoveram uma ruptura na dicotomia da ordem política, social e econômica, estabelecida após a segunda guerra mundial.

A realidade que emergiu durante este período criou uma nova dinâmica, onde os abatimentos bruscos se tornaram tão frequentes, que Peters $(1989$, p. 9) chegou a decretar que "previsibilidade [era] coisa do passado". O autor destacou que o aumento do número de variáveis decorrentes da globalização, do novo modelo especulativo dos mercados financeiros, da tecnologia e da própria visão da sociedade, estavam tornando o ambiente demasiadamente dinâmico e complexo para ser previsto. Foi diante deste cenário que autores como Zey-Ferrell (1981) identificaram que até mesmo as abordagens estruturalistas - inclusive as contingencialistas -, encontravam-se limitadas para lidar com os novos panoramas sociais vivenciados naquele período.

Durante a década de 1990, Prahalad e Hamel (1994) evidenciaram que o problema ainda persistia e que as crescentes pressões do mercado vinham se agravando por meio de rupturas sucessivas, como mercados aparecendo e desaparecendo a cada dia, pressões ambientais, mudanças repentinas nos interesses dos consumidores, dentre outros. Com base em percepção semelhante Drucker (1994) também afirmava que as transformações de nosso mundo estariam se acelerando e não seriam meros fenômenos de superfície, como se acreditava anteriormente. Assim como no oceano, a superfície aparentemente calma do dia 
a dia vinha mascarando a realidade conturbada das profundezas, permeada por eventos que alcançavam as entranhas da sociedade, alimentando significativas transformações nos ambientes organizacionais (DRUCKER, 1994). Para Prahalad e Hamel (1994) tal fenômeno tornava as decisões, a serem tomadas pelos níveis mais altos da organização, mais complexas, o que evidenciava as deficiências dos modelos clássicos.

Esta “[...] vigorosa expansão da literatura que se verificou a partir dos anos 1980 trouxe avanços importantes [...]" (FARIA, 2005, p. 63). Contudo, mesmo diante destas significativas transformações, vividas neste período, e das importantes contribuições que delas surgiram, até os dias de hoje a lógica profunda da estratégia "[...] baseia-se em pressupostos deterministas de causa e efeito [...]", onde o equilíbrio dinâmico é aceito "[...] como base razoável para a formulação das ações executivas." (PASCALE, 2002, p. 112)

Com base em percepção semelhante, Hurtado (2006) evidencia que existe uma crise de relevância nas concepções acerca da estratégia. $O$ autor afirma que mesmo o muito que já se falou, nesta área, a respeito da complexidade, encontra-se de fato pouco estruturado sob as perspectivas da mesma. Isso porque a estratégia, que deveria unificar as ações da organização frente ao meio, se encontra estruturada sobre um paradigma fragmentador. Uma percepção semelhante também pode ser vista na obra de Mintzberg, Ahlstrand e Lampel (1998) que ilustram o problema por meio da clássica fábula dos cegos que tentam descrever um elefante. Para tal, os autores colocam os pesquisadores da área da estratégia no papel dos cegos e o processo estratégico como um grande elefante, ainda por descobrir. Eles concluem que "como ninguém teve a visão para enxergar a fera toda, cada um tocou alguma parte e 'seguiu em total ignorância' a respeito das demais." ${ }^{1}$ (MINTZBERG; AHLSTRAND; LAMPEL, 1998, p. 3, tradução nossa).

Para Jaspers (1976), esta fragmentação da análise dos problemas - vista até os dias de hoje nas descrições acerca do problema estratégico - é a fonte de grande parte dos problemas dos modelos de gestão. Sob esta concepção, os modelos construídos a partir da fragmentação dos processos não podem contemplar as relações necessárias para a completa descrição da dinâmica dos fenômenos relacionados à transitoriedade do ambiente, no qual as organizações se encontram inseridas (CAPRA, 1983; FARIA, 2005).

\footnotetext{
${ }^{1}$ Do Inglês: "Since no one has had the vision to see the entire beast, everyone has grabbed hold of some part or other and 'railed on in utter ignorance' about the rest.
} 
Diante da problemática da fragmentação a posição de autores como Stacey (1995) se destaca. Para a autora "os sistemas humanos são movidos por ciclos de feedback, em que estão presentes a liberdade de escolha e as restrições, e o estado ocupado pelo sistema é o resultado de seus pormenores históricos." ${ }^{2}$ (1995, p. 480, tradução nossa)

Como exemplo da problemática levantada por Stacey (1995), pode-se tomar a situação atual de nossas relações com o meio ambiente.

Historicamente nenhum indivíduo, tribo ou nação pôde alterar o clima global, destruir milhares de espécies ou alterar o equilíbrio químico da atmosfera. Contudo isto está acontecendo hoje, com nossas ações individuais sendo mediadas e amplificadas por meio da crescente rede de instituições globais. ${ }^{3}$ (SENGE et al., 2008, p. 3, tradução nossa)

Este cenário ilustrado por Senge (2008, p. 3), demonstra claramente as dificuldades encontradas pelas organizações contemporâneas para lidar com a capacidade de amplificação produzida pelos laços de realimentação, em nossas relações com o planeta. Esta problemática tem levado o ser humano a se defrontar "[...] com toda uma série de problemas globais que estão danificando a biosfera e a vida humana de uma maneira alarmante, e que pode logo se tornar irreversível." (CAPRA, 2006, p. 23; SACHS, 2008)

Um outro exemplo desta dificuldade dos modelos clássicos, pode ser ilustrado pela recente crise financeira ocorrida no final do ano de 2008. Esta crise também foi provocada e agravada, em grande parte, pelo desprezo das organizações com relação aos impactos de suas próprias ações sobre o ambiente econômico (DELL'ARICCIA; IGAN; LAEVEN, 2008). A ruptura desta crise também trouxe à tona uma antiga preocupação, referente à importância dada pelos modelos de gestão baseados em estruturas ordenadas de controle, às previsões de futuro. Lethbridge (2008) listou diversas previsões equivocadas, feitas neste período, como os erros nas estimativas para os IPOs, para o preço do petróleo e até mesmo as previsões do guru financeiro e apresentador da CNBC Jim Cramer, que poucos dias antes da crise irromper afirmou que a economia americana já havia atingido o fundo do poço e aquele era o momento ideal para se investir.

\footnotetext{
${ }^{2}$ Do inglês: "Human systems are driven by feedback loops in which both free choice and constraint are present and the state systems occupy is the result of their detailed histories."

3 Do inglês: "Historically, no individual, tribe, or nation could alter the global climate, destroy thousands of species, or shift the chemical balance of the atmosphere. Yet that is happening today, as our individual actions are mediated and magnified through the growing network of global institutions."
} 
Lethbridge (2008) destaca que estas previsões sucumbiram em um espaço de tempo tão curto, que impossibilitou que até mesmo organizações bem estruturadas, sob as perspectivas contemporâneas, apresentassem qualquer tipo de reação contingencial, frente ao turbilhão que se formaria. Diante deste contexto, estas rupturas se configuram em um problema real, com grandes implicações para as organizações. Isso porque, estes fenômenos mostram a dificuldade encontrada pelos modelos de gestão contemporâneos, quando estes se deparam com transformações significativas, provocadas por laços de realimentação.

De acordo com Prahalad e Hamel (1994) o aumento crescente da competitividade global, acaba por ampliar ainda mais esta dificuldade das abordagens tradicionais em atender às demandas do ambiente. Pode-se dizer, então, que apesar das abordagens estruturadas a partir da década de 1980 terem se estruturado sobre arcabouços teóricos competentes, os processos de gerenciamento estratégico nas organizações contemporâneas demonstram que, na prática, tais perspectivas ainda parecem não estar completamente preparadas para atender às demandas de um ambiente complexo, permeado por mudanças cada vez mais rápidas e imprevisíveis (HURTADO, 2006).

Esta constatação possui uma inquietante analogia com as descrições feitas por Drucker (1994), ao analisar as dificuldades encontradas pelos modelos de gestão da década de 1980 , ao lidar com os cenários conturbados aos quais foram submetidos. Transportando as conclusões do autor para os dias de hoje, pode-se dizer que os velhos mapas e bússolas da realidade continuam insuficientes para orientar as decisões dos gestores, diante dos cenários de complexidade crescente.

Prahalad e Hamel (1994) destacam que esta situação tem origem no fato de que "muitos dos pressupostos que foram incorporadas nos modelos de estratégia tradicionais podem estar incompletos e/ou desatualizados à medida que nos confrontamos com o novo ambiente competitivo." ${ }^{4}$ (PRAHALAD; HAMEL, 1994, p. 6, tradução nossa) Bertero, Caldas e Wood (1999) propõem que estas dificuldades são oriunda da própria natureza da profissão dos administradores, que "[...] sempre foram chamados a solucionar problemas organizacionais, sem que houvesse tempo para que se criasse um espaço teórico e reflexivo." (BERTERO; CALDAS; WOOD JR., 1999, p. 174). Nesta busca por soluções específicas, os modelos teóricos contemporâneos acabaram se concentrando nas questões

4 Do inglês: "Many of assumptions that were embedded in traditional strategy models may be incomplete and/or outdated as we approach the new competitive milieu." 
diretamente relacionadas com o problema que se pretendia verificar, o que levou os modelos de gestão estratégica vigentes a serem construídos de forma a contornar as mudanças ambientais e não a proporcionar uma ampla compreensão acerca das mesmas (HURTADO, 2006). Em síntese, pode-se dizer que os administradores “[...] sempre procuraram equacionar o problema das mudanças, mas jamais se preocuparam com o problema da mudança" propriamente dito (BAUER, 1999, p. 122).

Nota-se com isso, uma concordância de que a dominância das abordagens reducionistas, permanece limitando o completo entendimento das relações que constituem o problema da estratégia nas organizações. Isso leva os executivos a erguerem as fundações de suas decisões sobre terrenos cársticos ${ }^{5}$, já que aspectos importantes dos cenários não são completamente definidos ou entendidos, em decorrência da fragmentação de seus conceitos.

Em última análise, esses problemas precisam ser vistos, exatamente, como
diferentes facetas de uma única crise, que é, em grande medida, uma crise de
percepção. Ela deriva do fato de que a maioria de nós, e em especial nossas
grandes instituições sociais, concordam com os conceitos de uma visão de mundo
obsoleta, uma percepção da realidade inadequada para lidarmos com nosso
mundo superpovoado e globalmente interligado. (CAPRA, 2006, p. 23)

Diante da evolução deste cenário Prahalad e Hamel (1994) destacaram a urgência para que as perspectivas acerca da estratégia sejam repensadas radicalmente - ver figura 1. Partindo do pressuposto de que uma "autocrítica saudável é um pré-requisito para o progresso" ${ }^{6}$, os autores argumentam em favor da busca por um novo paradigma no qual a disciplina da estratégia possa se amparar (PRAHALAD; HAMEL, 1994, p. 6, tradução nossa). Eles propuseram, então, que o cenário contemporâneo exige uma busca por uma ampla variedade de abordagens distintas, que passem, tanto pelo tratamento de assuntos pouco ou nada explorados pela área, como também por novas metodologias de pesquisa, que se diferenciem das abordagens fragmentadoras, adotadas pelos estudos tradicionais.

\footnotetext{
${ }^{5}$ Os solos cársticos são solos calcários que, devido à infiltração de água e à presença de áreas cavernosas, podem estar sujeitos a abatimentos bruscos sem sinais prévios denunciadores.

"Do inglês: "Healthy self-criticism is a precondition for progress."
} 


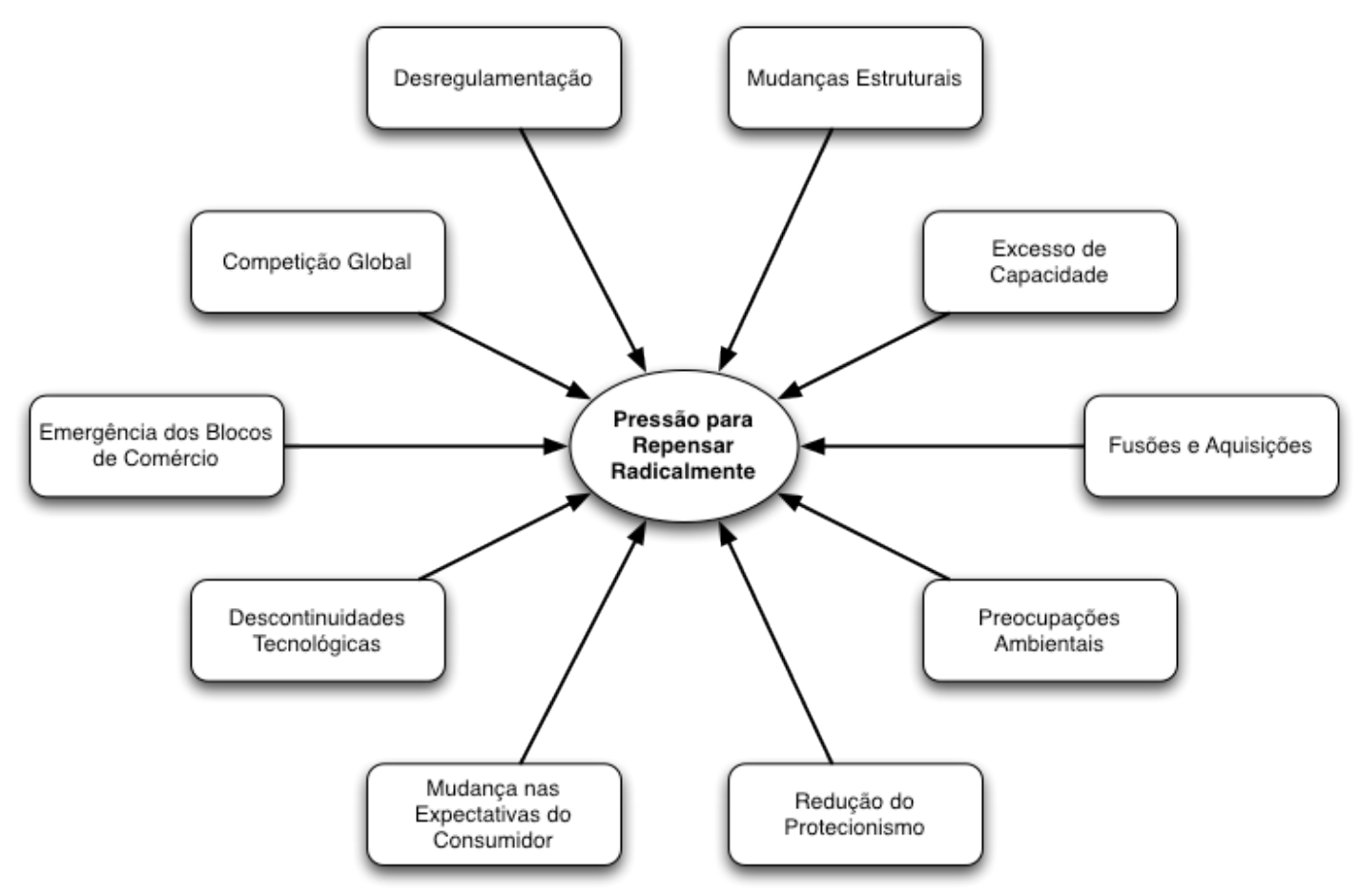

Figura 1 - A inevitável transformação na indústria. Fonte: Prahalad e Hamel (1994, p. 7, tradução nossa)

Portanto, o cenário de grandes transformações do mundo contemporâneo, aponta para a necessidade de se repensar, a partir de novas lentes, diversos aspectos referentes às transformações internas e externas da organização, onde reside a essência por trás da formação da estratégia. Neste sentido, Mintzberg, Ahlstrand e Lampel (1998) concordam com Prahalad e Hamel (1994) de que novas visões para o problema são bem vindas. Para os autores é preciso ir além do que já foi estudado sobre o problema e, acima de tudo, é preciso "[...] saber como este animal chamado formação de estratégia [...] realmente vive sua vida." ${ }^{7}$ (MINTZBERG; AHLSTRAND; LAMPEL, 1998, p. 373, tradução nossa)

Sem uma consciência clara acerca das maneiras com as quais interagem com o ambiente externo, as organizações podem produzir significativas alterações no cenário. Suas ações podem desencadear transformações com a capacidade de provocar elevados custos políticos, ambientais, sociais e financeiros, com reflexos desastrosos sobre a sociedade e, por consequência, sobre elas próprias. Isso amplifica a importância de se adotar novas óticas que permitam compreender os laços que ligam a organização ao meio e como a estratégia pode agir para harmonizar esta relação no longo prazo.

\footnotetext{
${ }^{7}$ Do inglês: "[...]to know how this beast called strategy formation [...] really lives its life."
} 
Neste sentido, Stacey (1995) afirma que a ciência da complexidade é aquela que possui a carga conceitual para romper com a fragmentação e permitir a compreensão das interações entre organização e ambiente, estratégia emergente e deliberada. A autora ainda destaca que para atingir este objetivo, os estudos na área de estratégia "[...] não devem se concentrar nas explicações e sim em hipóteses sobre todos os sistemas, suas dinâmicas, na condição sob a qual eles apresentam diferentes tipos de dinâmicas e nos relacionamentos entre a dinâmica e o sucesso inovador." ${ }^{8}$ (STACEY, 1995, p. 493, tradução nossa)

Logo, uma descrição detalhada da dinâmica de relações que envolve aspectos internos e externos da organização, é fundamental para compreender a relação da estratégia com o ambiente complexo que fomenta sua formação e vice-versa. Este cenário requer dos pesquisadores de estratégia "[...] não somente questionamentos de ordem epistemológica e metodológica, mas também de ordem ontológica." (FARIA, 2005, p. 63) Destarte, uma nova síntese capaz de descrever as relações internas e externas do problema estratégico, obtida por meio de uma metodologia estruturada sobre alicerces do pensamento complexo, se faz fundamental para permitir a unificação das concepções já existentes e garantir a ascensão de novas abordagens acerca de como a estratégia "vive sua vida", assim como propõem Mintzberg, Ahlstrand e Lampel (1998).

\subsection{PROBLEMA DE PESQUISA}

O cenário delineado ilustra a necessidade de uma avaliação dos aspectos ontológicos do próprio problema estratégico, por meio de uma abordagem epistemológica e metodológica compatível com as perspectivas da complexidade e da incerteza. Cabe então, questionar quais as variáveis e como se configura a dinâmica dos aspectos internos e

\footnotetext{
${ }^{8}$ Do inglês: “[...] will have to focus on explanation instead, on hypotheses about whole systems, their dynamics, the condition under which they will display different kinds of dynamic, and relationship between the dynamic and innovative success."
} 
externos do problema estratégico, quando o tratamos sob o olhar do paradigma da complexidade?

\subsection{OBJETIVO GERAL}

O presente esforço de pesquisa tem por objetivo sintetizar a dinâmica que governa os aspectos internos e externos do problema estratégico, assim como suas variáveis, tendo por base uma abordagem ontológica, epistemológica e metodológica compatível com os paradigmas científicos contemporâneos acerca da complexidade.

\subsection{OBJETIVOS ESPECÍFICOS}

- Organizar um quadro conceitual sobre as distinções entre o paradigma cartesiano e os paradigmas emergentes ligados à incerteza e à complexidade.

- Identificar as perspectivas contemporâneas acerca do problema estratégico e as concepções, processos e variáveis a ele relacionados.

- Elaborar procedimentos metodológicos adequados aos objetivos da pesquisa.

- Analisar as perspectivas referentes à complexidade que possuam relações com a dinâmica básica do problema estratégico

- Analisar os arranjos elementares das organizações sociais humanas que as especifique como sistema particular. 


\subsection{JUSTIFICATIVA}

No decorrer do tempo, a insuficiência dos modelos tradicionais de administração estratégica - baseados na previsibilidade dos cenários - ao lidar com as transformações do ambiente, acabou por reduzir a importância da estratégia, enquanto conceitos como implementação, execução e eficiência assumiram um papel central nas organizações (PRAHALAD; HAMEL, 1994). Tal processo removeu grande parte do espaço reflexivo da tomada de decisão, em pró de uma abordagem pragmática, estruturada no conceito de estratégia como padrão de comportamento organizacional.

Uma vez que Whittington (2004) lembra que a estratégia promove impactos sobre toda a sociedade, então as reflexões acerca dos impactos da mesma sobre o meio não só são cruciais para garantir a sobrevivência das organizações, como para maximizar o bem estar social. Sob esta perspectiva, as dificuldades dos modelos contemporâneos de gestão em prever os impactos de suas próprias ações sobre o meio é preocupante, já que agentes individuais podem disparar transformações que implicam em elevados custos políticos, ambientais, sociais e financeiros. Percebe-se a magnitude desta problemática em estimativas sobre as consequências da crise financeira de 2008, realizadas pelo Fundo Monetário Internacional (FMI), para o qual esta crise deverá produzir perdas, vinculadas a ativos financeiros, superiores a 4 trilhões de dólares, até 2010 (INTERNATIONAL MONETARY FUND, 2009).

Mas a questão financeira é apenas a ponta do Iceberg, dados do Departamento do Trabalho dos Estados Unidos mostram que de maio de 2008 a maio de 2009 o índice de desemprego naquele país cresceu mais de 70\% (BEREAU OF LABOR STATISTICS, 2009). Números semelhantes também foram sendo relatados por todo o mundo. $O$ desemprego extrapola as perdas para o nível social. A redução da renda familiar e o impacto sobre o psicológico dos desempregados atingem de forma significativa os núcleos familiares, "[...] que em casos extremos podem [até] resultar em violência" ${ }^{9}$. (FINEMAN, 1987, p. 160) Tais ocorrências podem provocar significativos impactos de longo prazo sobre os mais jovens.

\footnotetext{
${ }^{9}$ Do Inglês: “[...], which in extreme cases might result in violence."
} 
A queda na renda e o desespero também podem levar os indivíduos a atentarem contra o patrimônio ou até mesmo contra a vida de outrem (BRITT, 1997). As restrições ao consumo, provocadas por este fenômeno, também acabam por gerar um novo ciclo de perdas econômicas, que se proliferam produzindo rupturas sucessivas, capazes de perpetuar os impactos sociais e econômicos de um evento como este por longos períodos.

Questões como o aquecimento global também se encontram vinculadas às ações dos agentes e são ainda mais preocupantes do que uma crise, como a de 2008. As ações humanas e organizacionais, provocam significativas transformações no ambiente, “[...] aumentam o nível de dióxido de carbono na atmosfera, alteram a biogeoquímica do ciclo do hidrogênio e continuam modificando a cobertura e o uso da terra [...]"10 (VITOUSEK, 1994, p. 1861).

Uma vez que o ambiente como um todo é fruto destas interações, percebe-se então, uma crise de relevância acerca do conhecimento em estratégia, pois este não contempla os pressupostos capazes de levar as organizações a perceberem o real valor do ambiente no qual se encontram inseridas. Neste sentido, Thiollent (1983) destaca que uma reflexão epistemológica é responsabilidade de todo pesquisador e estes devem levar em consideração a base teórica e social a ser tratada diante da tecnologia que se propõem a desenvolver. Percepção semelhante já era levantada por Zey-Ferrell (1981), para quem uma nova ciência das organizações precisa emergir, trazendo consigo elementos que permitam compreender, também, os aspectos históricos e sociais, relacionados às organizações.

Em uma rede interligada, como nossa sociedade, as abordagens estruturadas de forma fragmentada e baseadas em uma perspectiva linear de causa e efeito, não contemplam os impactos transformadores das ações dos agentes sobre o próprio ambiente que os cercam. Esta percepção aponta para uma urgente necessidade de ruptura com o ideal clássico de causalidade linear, presente no fragmentado ambiente tradicional de gestão. Destarte, “[...] a complexidade, a dinâmica e a abertura teriam de tornar-se as palavras-chave do novo paradigma da ciência das organizações." (HASELHOFF, 1981, p. 31) Em um cenário permeado por intensas correlações, não seria razoável imaginar uma ciência das organizações onde a complexidade não se fizesse presente como fundamento epistemológico.

10 Do Inglês: "[...] increasing concentrations of carbon dioxide in the atmosphere; alterations in the biogeochemistry of the global nitrogen cycle; and ongoing land use/land cover change." 
Somente a partir de uma compreensão da dinâmica complexa que envolve próprio problema, é que o desenvolvimento da tecnologia estratégica pode ser capaz de auxiliar os gestores a compreenderem o caráter transitório do ambiente contemporâneo e, também, os reflexos de suas próprias ações sobre o ambiente e a organização. Diante de um contexto onde as organizações possuem forte impacto sobre os aspectos sociais e ambientais, justifica-se um estudo que busque a compreensão da dinâmica por trás dos aspectos internos e externos do problema estratégico, sob a ótica dos paradigmas científicos emergentes. Somente tendo por base uma síntese da complexidade emergente destas interações, é possível construir as bases de uma organização socialmente e ambientalmente sustentável.

\subsection{ESTRUTURA DO TRABALHO}

A primeira seção deste trabalho de pesquisa consiste na presente introdução. Ela é dividida em uma apresentação e mais cinco capítulos, onde são apresentados o problema de pesquisa, os objetivos da pesquisa, a justificativa para a elaboração deste esforço e a presente estrutura do trabalho. Além desta introdução, este trabalho é composto por mais cinco seções, cuja sequência e a relação com os objetivos específicos são apresentadas na figura 2.

Na seção denominada de "Do paradigma cartesiano à complexidade" o leitor será introduzido aos aspectos principais da ciência tradicional, aos conceitos acerca da complexidade e às suas respectivas implicações para as abordagens ontológica, epistemológica e metodológica, adotadas durante este esforço de pesquisa. Esta seção foi dividida em uma apresentação e mais cinco capítulos. Os quatro primeiros capítulos trazem um breve levantamento histórico/conceitual acerca das principais perspectivas epistemológicas presentes no pensamento contemporâneo. O último capítulo apresenta os 
principais aspectos da complexidade e um quadro síntese, comparando este paradigma com o paradigma cartesiano.

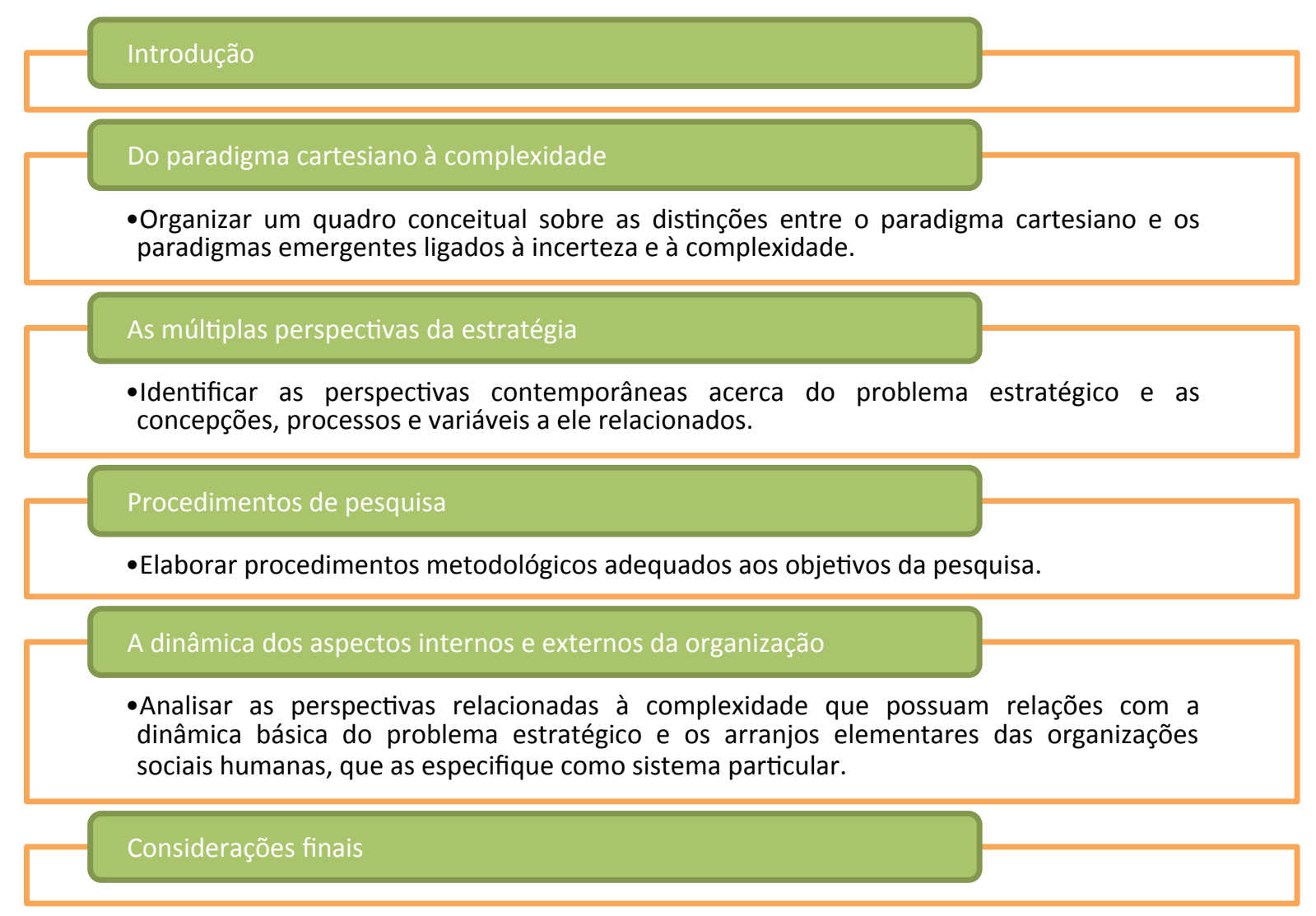

Figura 2 - Sequência de apresentação dos capítulos e sua relação com os objetivos específicos do trabalho Fonte: Elaborada pelo autor

A seção designada de "As múltiplas perspectivas da estratégia" tem por objetivo demonstrar a evolução dos conceitos acerca da estratégia, no mundo dos negócios, e a forma com a qual as principais vertentes, desenvolvidas no século $\mathrm{XX}$, abordam o problema do planejamento e da emergência estratégica. Este capítulo contempla uma apresentação e mais três capítulos, onde são feitas explanações sobre as perspectivas acerca do problema, desde as organizações militares da antiguidade até as escolas de administração estratégica, abordadas por Mintzberg, Ahlstrand e Lampel (1998). Ao final são avaliados os reflexos dos novos paradigmas científicos, mostrados na seção anterior, sobre as concepções acerca da estratégia.

A seção nomeada de "Procedimentos de pesquisa" aborda o método adotado para se atingir o objetivo deste trabalho. Esta seção é dividida em quatro capítulos que contemplam os detalhes que caracterizam os procedimentos de coleta e análise de dados utilizados e 
discutem o esforço de organização do mesmo. Nesta seção, a essência primeira do problema estratégico é exposta pela primeira vez, em sua forma pura e ainda não estruturada. Por fim, o último capítulo expõe as limitações decorrentes da abordagem adotada e as restrições encontradas no decorrer do desenvolvimento do trabalho.

Na seção "A dinâmica dos aspectos internos e externos da organização" são tratadas as bases conceituais, utilizadas para organizar o diagrama correspondente à essência primeira do problema estratégico, por meio de transposições por analogia. Seguindo os ideais de religação da complexidade, também optou-se por apresentar, neste capítulo, boa parte das conclusões do presente esforço de pesquisa.

Por fim, este trabalho apresenta suas considerações finais que, em última instância, são uma síntese dos aspectos mais importantes da descrição encontrada, associada a uma análise acerca de suas implicações.

É importante ressaltar que as possibilidades de expressão por meio do papel, ainda não alcançaram as perspectivas da complexidade, o que acabou por forçar este trabalho a adotar um fluxo linear de seções. Porém, houve um esforço, no decorrer da concepção das seções, com o objetivo de possibilitar que estas tivessem tanto uma identidade individual, como uma configuração que as identificasse com o todo do trabalho, capaz de nutrir, ao mesmo tempo, uma sensação de dependência e independência umas das outras. 



\section{DO PARADIGMA CARTESIANO À COMPLEXIDADE}

O termo paradigma foi cunhado por Kuhn (1996), com o objetivo de definir uma estrutura de acepção da realidade que serve de pano de fundo para a produção de teorias acerca da natureza dos fenômenos. Historicamente estes paradigmas ascenderam a partir da racionalização ou até mesmo da mitificação a respeito dos fatos que nos cercam (CAPRA, 1983; ANDERY et al., 1996; BAPTISTA; CAMPOS, 2007).

Como o conhecimento humano tem origem na experiência cotidiana, a própria construção do pensamento carrega em seu cerne os conflitos vivenciados pelos indivíduos, diante do momento histórico ao qual pertencem. Pode-se dizer, então, que as reflexões e teorizações acerca dos fenômenos acabam por servir aos interesses relacionados às próprias “[...] alterações nas condições materiais da vida humana" (ANDERY et al., 1996, p. 13). Destarte, "a tentativa de elaborar um pensamento racional tem marcas próprias [...]" inerentes ao momento histórico do qual faz parte (COPLESTON, 1993; ANDERY et al., 1996, p. 20).

A evolução do pensamento humano no decorrer da história está intimamente ligada ao próprio surgimento e desenvolvimento do pensamento científico e os paradigmas por ele instituídos (ANDERY et al., 1996). Neste contexto, Kuhn (1996) lembra que a própria ciência, é um paradigma desenvolvido a partir de uma dinâmica de constante apreciação dos padrões, estruturada sobre as perspectivas dogmáticas e pragmáticas que se instauraram em um determinado momento histórico.

Uma vez que a "ciência é mais do que um corpo de conhecimento, é um modo de pensar." (SAGAN, 2006, p. 43), ela carrega em seu cerne certo grau de arbitrariedade, oriunda da concepção de realidade e dos interesses dos grupos sociais responsáveis por sua consolidação (KUHN, 1996). Diante desta constatação, a ciência nada mais é do que um reflexo da percepção daqueles grupos que a formulam. Desse modo, pode-se dizer que "[...] as teorias científicas não são o reflexo puro e simples das realidades objetivas, mas coprodutos das estruturas do espírito humano e das condições socioculturais do conhecimento." (MORIN, 2007b, p. 55) 
Quando se parte do pressuposto de Bachelard (1975, p. 177, tradução nossa), para quem o espírito humano possui "[...] uma estrutura variável desde o instante em que o conhecimento tem uma história” ${ }^{11}$, a própria natureza histórica do pensamento adquire uma influência significativa sobre a arbitrariedade dos pensadores de cada período e vice-versa. Dentro deste contexto, o pensamento, assim como seus derivados, têm um intrincado relacionamento com o momento ao qual o indivíduo pertence, transformando o ser ao passo que se transforma (BACHELARD, 1975). Como o conhecimento acaba por servir aos interesses e percepções de grupos específicos, este ciclo transformador seria extensível à própria sociedade, uma vez que esta é, na verdade, um conjunto de inter-relações entre indivíduos submetidos a esta dinâmica.

Devido à profunda ligação entre a ciência e a história, os embates acerca do permanente e do transitório acabaram por permear a essência do pensamento humano e, por consequência, da própria ciência. Estes embates remetem ao infinito dos debates históricos entre dominantes e dominados. Em um conflito, seja ele social, econômico, ou intelectual, os dominantes defendem e almejam a estabilidade de seu status quo, enquanto os dominados almejam a emergência de seus interesses (BACHELARD, 1975; CAPRA, 1983; ANDERY et al., 1996). Nestas condições, se estabelece uma alternância entre a predominância dos pontos de vista estruturados sobre tal conflito, sendo que a influência de um determinado paradigma é dada a partir do equilíbrio de forças entre estas perspectivas antagônicas, determinadas pela realidade histórica na qual o homem se encontra inserido(BACHELARD, 1975; CAPRA, 1983; ANDERY et al., 1996).

O surgimento de novos padrões, fatos ou teorias pode, então, conduzir a mudanças na percepção humana acerca da realidade, mudanças essas que podem impactar diretamente nos pilares dos modelos de apreensão da realidade, de forma a provocar rupturas nos paradigmas vigentes. Sob as perspectivas da ciência, Kuhn (1996) denominou este tipo de ruptura de "revoluções científicas".

Uma revolução científica não decorre, portanto, de processos lineares de acumulação, mas de um evento abrupto e não estruturado, algo como um poderoso insight, após o que o cientista se vê como que remetido a um outro mundo, distinto daquele regido pelo paradigma ultrapassado. (BAUER, 1999, p. 22)

\footnotetext{
${ }^{11}$ Do Francês: “[...] une structure variable dês l'intant ou la connaissance a une histoire”
} 
Destarte, as revoluções científicas são capazes de desencadear crises no próprio pensamento, com consequências sobre a própria sociedade que o materializa e vice-versa (BACHELARD, 1975; KUHN, 1996). A percepção de que a ciência está sujeita ao momento histórico e é passível de revoluções em sua estrutura, possui reflexos significativos sobre o ideal de busca pela verdade absoluta. Neste cenário a "ciência nunca oferece respostas certas. Uma teoria científica pode, no máximo, ganhar aceitação universal, ou quase universal na comunidade científica, como a melhor explicação disponível naquele momento"12 (DEVLIN, 1996, p. 348, tradução nossa)

Uma vez que os homens elaboram seus constructos para apreender a realidade dentro de um contexto de constante interação entre história e pensamento, até mesmo os paradigmas podem se tornar limitados, quando os desafios e perspectivas impostos pelo meio divergem dos esperados e estudados no período anterior. O reconhecimento de cada momento histórico se torna, então, parte fundamental para compreensão das arbitrariedades contidas nos axiomas de cada período. Desse modo, os questionamentos acerca dos eventos que conduziram o pensamento humano ao atual contexto, são de suma importância para a compreensão dos pontos de vista adotados pela ciência da administração. Compreensão essa, que se mostra fundamental para a construção de uma postura de pesquisa, compatível com as necessidades inerentes ao estudo das interações sistêmicas contemporâneas.

\subsection{O ANTIGO EMBATE ENTRE A PERMANÊNCIA E A MUDANÇA}

\footnotetext{
${ }^{12}$ Do inglês: "Science never provides 'right' answers. At most a scientific theory might gain universal or almost
} universal acceptance among the scientific community as 'the best explanation available at the time'." 
“Para começar do início, o que chamamos hoje de 'ciência cartesiana' teve seu princípio com os antigos gregos." ${ }^{13}$ (DEVLIN, 1996, p. 344, tradução nossa) Entre os séculos VI a.C. e V a.C. as tentativas de definir a natureza da realidade deram passos importantes dentro da filosofia ocidental. Nesta época os filósofos Parmênides de Eléa e Heráclito de Éfeso deixaram a base do que seriam as teses antagônicas acerca da permanência e da transitoriedade da realidade. Estes filósofos teriam "inspirado uma grande variedade de ideias diferentes" ${ }^{14}$ e talvez tenham sido os filósofos pré-socráticos de maior impacto sobre a cultura ocidental (KONDER, 1990; OSBORNE, 2005, p. 80, tradução nossa).

No século VI a.C. o jônio Heráclito de Éfeso foi um dos primeiros pensadores ocidentais a encarar a transitoriedade como algo inerente à própria natureza humana (KONDER, 1990; OSBORNE, 2005). Uma das maiores contribuições de Heráclito, para o pensamento moderno, vem de sua afirmação de que "tudo existia em constante mudança, que o conflito é o pai e o rei de todas as coisas" (KONDER, 1990, p. 8). Para Heráclito a realidade se daria pelo vir-a-ser.

Tal convicção fica evidente quando o filósofo conclui que "vida ou morte, sono ou vigília, juventude ou velhice são realidades que se transformam umas nas outras". (KONDER, 1990, p. 8; OSBORNE, 2005). Assim, a existência dependeria da própria contradição, onde o universo estaria pautado por um fluxo contínuo de transformações, oriundas do conflito entre perspectivas antagônicas que gravitam em torno de uma identidade permanentemente reconhecível do ser. Destarte, a própria transformação só poderia existir em função se seu antagônico, a permanência.

Seus famosos fragmentos B91, B12 e B49a - também chamados de fragmentos do rio - destacam esta perspectiva, quando este afirma que "[...] não é possível a um homem se banhar no mesmo rio por duas vezes [...]"15 (OSBORNE, 2005, p. 90, tradução nossa), o que induz à conclusão, encontrada em seu fragmento B12, de que tanto o rio como o homem haveriam mudado quando este retornasse para o segundo banho (OSBORNE, 2005). Nota-se em tal metáfora que mesmo com o homem e o rio tendo mudado, estes permanecem reconhecíveis um ao outro. Para Heráclito existiria, então, uma permanência da identidade do ser, permeada por um fluxo de transformações contínuas, ocorridas em diversos graus.

\footnotetext{
${ }^{13}$ Do Inglês: "To Begin at the beginning, what is nowadays often referred to as 'Cartesian science' has its most identifiable beginning with the ancient Greek."

${ }^{14}$ Do Inglês: "[...] inspired such a wide range of different ideas [...]".

${ }^{15}$ Do Inglês: "[...] is not possible to step twice into the same river [...]".
} 
Dentre as ideias de Heráclito de Éfeso se encontram, também, questões ontológicas que remetem a questionamentos da fenomenologia moderna, como seu fragmento B5, em que este afirma que "a água do mar é pura para o peixe e impura para humanos; a estrada é a mesma nas duas direções; as ações de cortar, queimar e infligir dor são boas em caso de cirurgia e ruins em caso de tortura"16 (OSBORNE, 2005, p. 83, tradução nossa). A partir destas colocações Heráclito propunha questionamentos sobre a influência exercida pelo próprio ser a respeito da construção da realidade que o cerca.

Em uma perspectiva antagônica à de Heráclito - que defendia ser a transformação algo presente e fundamental para a compreensão da dinâmica da realidade - o filósofo eleático Parmênides defendia, por volta do século $V$ a.C., a ideia de que a realidade seria essencialmente estática e que as mudanças percebidas no ambiente seriam fruto de uma mera ilusão do vir-a-ser (SPINELLI, 2003; HUSSEY, 2005). Em seu manuscrito DK 28, no qual ele discute a natureza da realidade, Parmênides deixa clara sua posição acerca do tema, ao afirmar de forma direta e enfática que "a realidade é completa única e imutável” ${ }^{17}$ (HUSSEY, 2005 , p. 129, tradução nossa). Dentro desta perspectiva - que se convencionou chamar de metafísica - Parmênides deixou como principais contribuições de sua obra "[...] a distinção entre conhecimento e opinião; a aplicação da lógica na descoberta da natureza da realidade; e a afirmação da prática, da eficácia empírica das 'opiniões' sistematizadas." ${ }^{18}$ (HUSSEY, 2005, p. 136, tradução nossa).

Mesmo com o apoio posterior de pensadores importantes, as concepções abstratas de Heráclito the renderam a alcunha de Obscuro e suas ideias acabaram deixadas em segundo plano (KONDER, 1990; OSBORNE, 2005). No embate entre o ser metafísico de Parmênides e o vir-a-ser dialético de Heráclito, "a perplexidade natural do homem diante da mudança [...]" e o interesse na manutenção do status quo das classes dominantes, acabaram conduzindo à predominância das ideias metafísicas de Parmênides (KONDER, 1990; ANDERY et al., 1996; BAUER, 1999, p. 124).

\footnotetext{
${ }^{16}$ Do Inglês: "sea water is pure for fish and impure for humans; the road up and the road down is one and the same; the actions of cutting, burning and inflicting pain are good when performed in a case of surgery, and bad in a case of torture".

${ }^{17}$ Do Inglês: "Reality is complete, unique, unchanging"

${ }^{18}$ Do Inglês: "[...] the distinction between knowledge and opinion; the application of logic in the discovery of the nature of reality; and the assertion of the practical, empirical effectiveness of systematized 'opinions'."
} 


\subsection{A CIÊNCIA EM BUSCA DAS CERTEZAS}

Durante a idade média os conceitos metafísicos enfrentaram a fúria religiosa do período e ficaram esquecidos até que "[...] na terceira década do século XIII emergiram os primeiros sinais de uma nova metafísica." ${ }^{19}$ (MARRONE, 2004, p. 204, tradução nossa). Nesta época Robert Grosseteste e William of Auvergne se empenharam na propagação dos ideais neo-platonistas. Grosseteste deu um novo significado às noções aristotélicas sobre o conhecimento verdadeiro e estabeleceu o ideal empírico da busca pela verdade, em antagonismo com o divino (CROMBIE, 1950; MARRONE, 2004). Este renascimento dos ideais metafísicos foi pilar para que, no século XVII, René Descartes pudesse forjar as bases do que denominamos hoje de ciência (CAPRA, 1983; GAUKROGER, 2005).

Descartes foi um filósofo cuja obra remete a uma busca incessante pelas certezas e pela verdade científica. O filósofo buscava construir um juízo sólido com base na obtenção das essências absolutas, nas unidades mais simples de um determinado fenômeno. Para tal, afirmava que "[...] não há nada de tão múltiplo ou de tão espalhado que não possamos, por meio da enumeração de que tratamos, encerrar em determinados limites e reduzir a alguns pontos essenciais." (DESCARTES, 2007, p. 54)

Desse modo, o ideal de busca pelo conhecimento de Descartes (2007), passa por estudar o mais simples para, através das relações causais entre estas partes, realizar a construção de um todo. Em outras palavras, no método cartesiano as partes são analisadas individualmente, isoladas de seu contexto, para depois se construir um todo coerente, através da análise individual de cada relação causal que compõe o fenômeno. Desse modo, Descartes (2007) via na simplicidade as coisas primeiras, o cerne do fenômeno.

Descartes ainda afirmava que a experiência comum seria um agente infalível da busca pelo conhecimento, no qual se nega o abstrato, em detrimento desta experiência (BACHELARD, 1983, p. 14). Portanto, para ele não importa se a experiência é obtida através da percepção individual. A percepção do ser, acerca da realidade, se constituiria em um sinal claro da existência do objeto. Ele entendia que o sujeito se relacionava diretamente com

\footnotetext{
${ }^{19}$ Do Inglês: "[...] third decade of the thirteenth century there emerge the first signs of a new metaphysics."
} 
suas ideias e, desta forma, possuía um retrato perfeito do mundo, dos fatos e dos objetos que o compunham (CAPRA, 1983; GAUKROGER, 2005; DESCARTES, 2007).

Muitos dos ideais de Descartes vinham seu encantamento pelos relógios que foi transformado em sua referência acerca da constituição da natureza. O universo cartesiano possui uma característica mecânica, com uma natureza possível de ser apreendida pelo conhecimento humano (CAPRA, 1983; GAUKROGER, 2005; DESCARTES, 2007). Diante desta concepção Descartes atribuía ao sujeito as responsabilidades pelas imprecisões e incertezas do conhecimento, já que para ele o objeto seria sempre conhecível e determinável. Então o sujeito, quando desprovido de um juízo sólido, é que seria transformado em ruído e possibilidades (MORIN, 2007c).

Portanto, a natureza, como vista por Descartes, seria simples e permanente em sua essência. Diante desta concepção de mundo, era de se esperar que Descartes (2007) desenvolvesse um encantamento pela matemática, sua simplicidade e sua ordem. Ele considerava que a matemática e a geometria eram os caminhos para a construção de um conhecimento verdadeiro, já que estas seriam isentas de incerteza e tratariam, através da dedução, de um objeto tão puro e simples que não dependeriam de "[...] nenhuma suposição que a experiência possa deixar duvidosa [...]" (DESCARTES, 2007, p. 10).

Este ideal de ciência, foi coroado ainda no século XVII por Sir Isaac Newton, um cientista que foi particularmente influenciado por Descartes (DEVLIN, 1996). Os esforços de Newton culminaram com os três volumes de sua obra denominada "Princípios Matemáticos da Filosofia Natural"20. Esta importante contribuição, publicada em 1687, descrevia as 3 leis para o movimento dos corpos, a partir de uma coerente e robusta base matemática (NEWTON, 1846). Apesar de sua missão, considerada complexa para o período, o cálculo diferencial de Isaac Newton conseguia prever, com alta precisão para a época, a dinâmica dos corpos. Isso teve um grande impacto no meio científico, pois consolidou a ideia de um universo mecânico, causal, determinista e regido por leis matemáticas, conforme previra Descartes (CAPRA, 1983; BAUER, 1999).

O sucesso do paradigma cartesiano, em ciências tidas como de forte caráter realista, como a física e a matemática, o levou a ser extrapolado para as mais diversas áreas do conhecimento (CAPRA, 1983; BAUER, 1999; GAUKROGER, 2005; CAPRA, 2006). Rapidamente

\footnotetext{
${ }^{20}$ Do Latim: “Philosophiae Naturalis Principia Mathematica”.
} 
as engrenagens do relógio foram substituídas nas mais diversas áreas do pensamento, inclusive nas ciências sociais, onde os indivíduos e grupos sociais passaram a ser tratados como engrenagens sociais. Assim, a máscara cartesiana que tratava a natureza como algo permanente, se tornou a principal referência para os constructos da realidade durante os séculos que se seguiram (CAPRA, 1983; CASANOVA, 2006).

No século XIX, a essência mecânica e fragmentadora deste paradigma se estruturou, principalmente, segundo a concepção do pensamento empirista do positivismo do filósofo Isidore Auguste Marie François Xavier Comte (MILLER, 1987). O positivismo se estrutura, em grande parte, nos preceitos ontológicos e epistemológicos do pensamento cartesiano e do empirismo de Francis Bacon (RIBEIRO JR., 1982, p. 13).

$\mathrm{Na}$ concepção de Comte a ciência, trata-se de uma extrapolação de formulações gerais a partir de observações de fenômenos particulares. Tal processo se desenvolveria por meio da "[...] observação dos fatos, adivinhando-lhes por indução as leis da coexistência e da sucessão, e deduzindo dessas leis, por via da consequência e correlação, fatos novos que escaparam da observação direta, mas que a experiência verificou." (RIBEIRO JR., 1982, p. 17)

\begin{abstract}
O positivismo é, portanto, uma filosofia determinista que professa, de um lado, o experimentalismo sistemático e, de outro, considera anticientífico todo o estudo das causas finais. Assim admite que o espírito humano é capaz de atingir verdades positivas ou de ordem experimental, mas não resolve as questões metafísicas, não verificadas pela observação e pela experiência. (RIBEIRO JR., 1982, p. 15)
\end{abstract}

Comte também era um defensor da fragmentação do conhecimento que o autor constantemente extrapolava para o ambiente social, por meio do ideal de especialização sistemática das funções (RIBEIRO JR., 1982). Estas ideias levaram a uma profunda revolução na própria concepção da sociedade. A fragmentação e o universo estático acabaram por nutrir um relacionamento íntimo com a própria revolução industrial, pois sustentavam a divisão especializada do trabalho e o foco na engenharia, tão pertinentes a este processo histórico.

Com as disciplinas "as ligações e solidariedades deste objeto com outros objetos tratados por outras disciplinas [passaram] a ser negligenciadas, assim como as ligações e solidariedades deste objeto com o universo do qual faz parte." (MORIN, 2007b, p. 40) Os pensadores foram então, conduzidos a uma especialização que "[...] levou a uma maior precisão no conhecimento dos fenômenos", mas "[...] chegou a afetar o conhecimento 
profundo da própria realidade que pretendia compreender e mudar. Escondeu 'causas', calou 'efeitos', suplantou 'fins'." (CASANOVA, 2006, p. 16)

Diante das concepções cartesianas e positivistas, "a noção de um universo orgânico, vivo e espiritual foi substituída pela noção de um mundo como uma máquina, e a máquina do mundo tornou-se a metáfora dominante da era moderna." (CAPRA, 2006, p. 34) Mesmo quando esta concepção se mostrava incompatível com a realidade observada, as inconsistências eram atribuídas a erros do observador, já que esta forma da apreensão da realidade era extremamente pertinente para atender aos anseios humanistas, da nova burguesia que ascendia naquele período. Assim os séculos seguintes a Descartes acabaram por tecer e consolidar a ideia de uma realidade social estática, permeada por mudanças ilusórias, o que levou o pensamento predominante, até o século $X X$, a se tornar praticamente um sinônimo do corpo de conhecimento construído através do paradigma cartesiano.

\subsection{OS CONFLITOS SOCIAIS COMO A MANIFESTAÇÃO DE UM MUNDO TRANSITÓRIO}

Assim como a metafísica, os movimentos gregos em torno da concepção da mudança e da dialética também sofreram com a repressão da teologia da idade média. Depois vários séculos, sufocada pelos mitos medievais e pelos paradigmas metafísicos, a dialética grega e o vir-a-ser de Heráclito voltaram a ganhar força no século XVIII, quando as reviravoltas sociais, promovidas pela revolução francesa, deram uma nova perspectiva as transformações sociais.

Uma das figuras que lançou um novo olhar para a dialética foi o alemão Immanuel Kant. Ele retomou o conceito aristotélico de consciência como "[...] a consciência de um ser que interfere ativamente na realidade" (KONDER, 1990, p. 21). Seguindo os passos de Kant, Georg Wilhelm Friedrich Hegel lançou, ainda no século XVIII, as concepções básicas do que 
viria a ser a dialética moderna. Em meio às suas angústias a respeito do trabalho e sua relação com a revolução industrial, o filósofo reafirmou o conceito de contradição da realidade de Heráclito em uma concepção que tornava a reunir o ser e o pensamento (HEGEL, 1999).

Hegel (1999) se utilizava da premissa de que a transformação se desenvolve a partir da oposição dos contrários, cuja interação promove uma nova síntese da realidade que contempla partes dos opostos originais, associadas a novos aspectos produzidos pela interação dos mesmos - ver figura 3. O resultado desta interação seria responsável pela formação de uma nova contradição a ser contestada em um processo de infinitas interações.

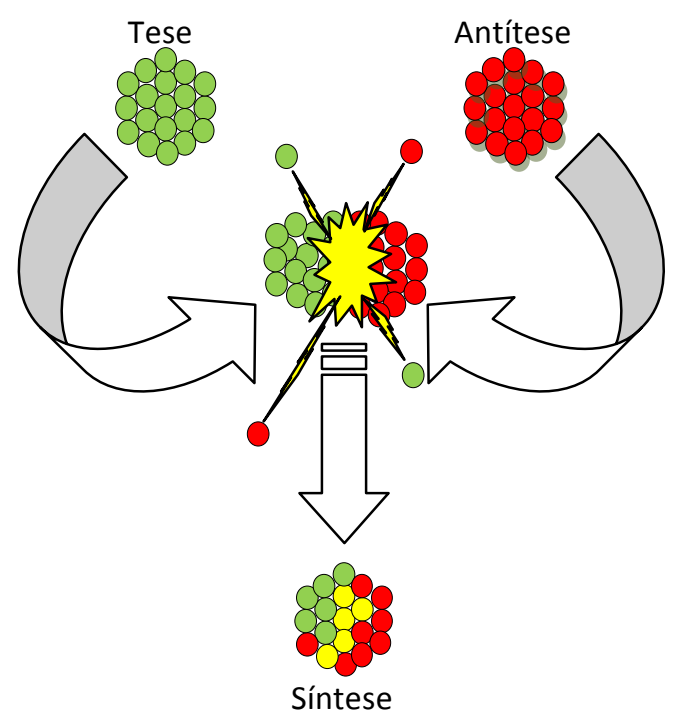

Figura 3 - Dinâmica das interações dialéticas de Hegel Fonte: Elaborada pelo autor

As concepções de Hegel (1999) conduziram à percepção de que a sociedade, como um todo, seria essencialmente transformadora, ao passo que o ser é espiritual. Tal capacidade transformadora remete ao infinito dos conflitos históricos. Nesta acepção moderna, a dialética significa, portanto, "[...] o modo de pensarmos as contradições da realidade, o modo de compreendermos a realidade como essencialmente contraditória e em permanente transformação." (KONDER, 1990, p. 8) Destarte, os fragmentos B91, B12 e B49a e as constatações de Heráclito acerca das oposições dos contrários, podem ser usadas como metáforas fortes para muitas das concepções da dialética moderna.

Diante de uma percepção superficial das dinâmicas sociais, que se encontravam ofuscadas pela ascensão da metafísica, a dialética precisava encontrar um espaço para 
prosperar. Esta contribuição veio por meio das rupturas provocadas pela revolução francesa. Este importante evento contribuiu para expor, aos filósofos iluministas, a natureza dinâmica das mudanças históricas e sociais. Alguns pensadores, como Denis Diderot e Jean-Jacques Rousseau, realizaram, cada qual à sua maneira, reflexões sobre a mudança social e a ordem imposta naquele momento, trazendo importantes contribuições para formulação das concepções acerca do caráter transitório da sociedade (KONDER, 1990).

A nova dialética teve seu ápice nas mãos de Karl Heinrich Marx. Marx foi discípulo de Hegel e em suas discussões sobre o trabalho, ele inverteu o conceito da dialética hegeliana. Marx propôs substituição da visão espiritualista de Hegel por uma perspectiva materialista do sujeito histórico, que mais tarde seria a base da doutrina comunista moderna. Esta nova dialética se originou de um momento histórico, permeado pelas angústias acerca da natureza do trabalho e das relações de dominância que dele derivam (KONDER, 1990; CASANOVA, 2006). Ela reafirmava o caráter ligado às aflições históricas das lutas de classe do período iluminista, tal como o pensamento cartesiano afirmou o humanismo renascentista e a consolidação da classe burguesa.

Marx redefiniu a dialética como sendo um método que vai do concreto ao abstrato, conceito que foi posteriormente aprimorado por Friedrich Engels, que reincorporou a concepção hegeliana de que o pensamento está submetido às leis da natureza e da sociedade (KONDER, 1990; CASANOVA, 2006). Juntos Marx e Engels concluíram "[...] que toda a história transcorrida até então tinha sido uma história de lutas de classes [...] que estaria assumindo formas cada vez mais complexas" (KONDER, 1990, p. 32; MARX; ENGELS, 2001)

Estruturados em sua percepção acerca do potencial transformador da sociedade, Marx e Engels (2001, p. 55) identificaram que para a burguesia existe "[...] uma necessidade [de] penetrar por toda parte, estabelecer-se por toda parte, criar relações por toda parte." Com base nesta concepção, os autores perceberam o potencial transformador daquele momento histórico e anteciparam, por meio de sua nova concepção epistemológica, fenômenos como o nascimento de novas necessidade, a busca por produtos e produção intelectual em locais longínquos, a submissão do campo à cidade, a redução na dispersão dos meios de produção e o domínio das classes chamadas pelos autores de burguesa, tanto no âmbito político como no âmbito econômico. 
Os pensadores dialéticos tinham a compreensão de que há a mudança mas também há a permanência, de que "a totalidade é mais do que a soma das partes que a constituem." Eles percebiam que ao tomar um banho no mesmo rio, o homem e o rio seriam os mesmos, mas transformados (KONDER, 1990, p. 37). A partir da concepção de uma sociedade conflituosa, Marx e Engels talvez tenham sido os primeiros a identificar e descrever o provável trajeto de fenômenos sociais complexos, como a globalização (ALENCAR, 2001). No entanto, até o final do século XIX, até mesmo os esforços destes pensadores importantes, como Marx, Hagel e Engels, não haviam sido suficientes para provocar uma ruptura com a permanência e o determinismo do paradigma cartesiano (CAPRA, 1983; KONDER, 1990).

\subsection{O NASCIMENTO DE UM NOVO ESPÍRITO CIENTÍFICO}

“Em fins do século [XIX], acreditava-se ainda no caráter empiricamente unificado de nosso conhecimento do real." (BACHELARD, 1983, p. 13) Ainda que se mostrasse significativamente limitada, para possibilitar uma ampla compreensão dos fenômenos naturais, sociais e organizacionais, as abordagens cartesianas prevaleceram como a principal alternativa para explicação dos mesmos. Tal condição levou à descrições dos fenômenos que, segundo Bachelard (1975, p. 107, tradução nossa), seriam incapazes de ligar "[...] todos os aspectos do fenômeno com o mesmo rigor." ${ }^{21}$ Porém, no início do século XX as ciências naturais realizaram descobertas de profundo impacto ontológico e epistemológico, que pulverizariam alguns dos pilares do paradigma cartesiano (CAPRA, 1983; BAUER, 1999).

Nesta época, Lord Rayleigh e Sir James Jeans encontraram um paradoxo cuja solução desencadearia uma ruptura que traria de volta a incerteza ao universo da ciência. Estes dois cientistas estudavam a irradiação de energia de um corpo aquecido, quando se depararam com uma questão intrigante. Na visão da física clássica um objeto deveria emitir radiação

\footnotetext{
${ }^{21}$ Do Francês: “[...] tous les aspects du phénomène avec la même rigueur."
} 
eletromagnética igualmente em todas as frequências. Como as frequências possíveis são infinitas, então estes cientistas concluíram que um corpo aquecido deveria emitir uma quantidade infinita de energia. Tal conclusão se constituía em uma clara aberração empírica já que, segundo a mecânica clássica, a emissão infinita de energia levaria ao decaimento no nível de energia do elétron, levando-o a se precipitar sobre o núcleo. Mediante esta condição, o átomo deveria ser instável o que impossibilitaria a existência do próprio universo, como o conhecemos (HAWKING, 1988).

Foi o físico alemão Max Planck quem resolveu a incoerência da irradiação eletromagnética de um corpo aquecido. Para tal, Planck postulou que as "[...] ondas não [poderiam] ser emitidas em uma razão arbitrária, mas apenas em determinadas quantidades que chamou de quanta." (HAWKING, 1988, p. 86) Em outras palavras, a emissão de energia por um corpo aquecido se daria de forma discreta e não de forma contínua, como previra a visão clássica. Planck foi além, e demonstrou que os quanta emitidos seriam proporcionais à frequência, sendo assim, seriam maiores tanto quanto fossem maiores as frequências irradiadas (HAWKING, 1988). Portanto, a emissão de radiação eletromagnética, em uma determinada frequência, só poderia ocorrer se houvesse energia disponível para tal. Desse modo, a partir de uma determinada frequência a energia necessária para irradiar um determinado comprimento de onda seria maior do que a disponível. Assim, seria impossível que houvesse qualquer tipo de irradiação em frequências que estivessem além do limite de energia disponível.

Em 1926 o postulado quântico de Planck levou o alemão Werner Heisenberg, a se deparar com uma questão que abalaria as estruturas dos paradigmas científicos vigentes (CAPRA, 1983; HAWKING, 1988, 2001). Heisenberg objetivava prever a posição e a velocidade futura de uma partícula subatômica e, conforme os preceitos da física clássica, necessitava medir a velocidade e a posição inicial desta partícula. Para efetuar sua mensuração, Heisenberg construiu um microscópio de raios gama, que realizaria a medição a partir da forma com a qual os fótons irradiados sobre uma partícula se dispersassem ao interagir com a mesma (BOHR, 1928; CHIBENI, 2005).

Para que a medição do estado futuro de uma partícula fosse precisa, era necessário que esta interação, entre o instrumento de medição e o objeto, se desse com o mínimo possível de alterações em seu estado. No mundo macroscópico os procedimentos de medição implicam em perturbações desprezíveis nas condições do objeto, o que colabora 
para a precisão das mesmas. Porém Heisenberg descobriu que no mundo subatômico, a interação entre o instrumento de medição e o objeto implica em uma incerteza acerca das dimensões medidas (BOHR, 1928; CHIBENI, 2005).

A abordagem experimental adotada por Heisenberg, tem sua precisão ligada a dois fatores. O primeiro consiste em uma limitação na precisão com a qual poderíamos mensurar as coordenadas da partícula. Neste experimento, “[...] não somos capazes de determinar a posição da partícula de maneira mais precisa do que através da distância entre as cristas das ondas" irradiadas sobre a mesma. Assim, a precisão na obtenção das coordenadas da partícula, estaria diretamente ligada ao comprimento de onda utilizado pelo instrumento de medida (BOHR, 1928; BUNGE, 1987; HAWKING, 1988, p. 87; CHIBENI, 2005). O segundo fator consiste em que ao emitir uma onda eletromagnética contra uma partícula, cria-se um momento oriundo desta interação. Este momento altera a velocidade da partícula de maneira proporcional à quantidade de energia fornecida pela mesma e é imprevisível, uma vez que o fóton atinge a partícula espalhado de forma indeterminada dentro de seu ângulo de incidência.

Nestes sistemas a imprecisão na medição é amplificada, um pequeno erro pode ser propagado por futuras interações de grande incerteza, levando à perda significativa de capacidade de previsão do futuro. Assim, a precisão na estimativa futura do momento diminui, conforme é aumentada a quantidade de energia fornecida para o sistema. Desse modo, as medições no experimento de Heisenberg seriam tanto mais precisas quanto menores as quantidades de energia e os comprimentos de onda utilizados no mesmo (BOHR, 1928; HAWKING, 1988; CHIBENI, 2005).

Heisenberg percebeu, então, o quão inquietante era o postulado de Max Planck. De acordo com o postulado quântico não se pode emitir ondas eletromagnéticas a esmo, é preciso pelo menos um quantum para se obter uma determinada frequência, sendo que quanto maior a frequência, maior será a energia necessária. Destarte, é impossível determinar com precisão arbitrária a velocidade e a posição futura de uma partícula, uma vez que, para aumentar a precisão na mensuração das coordenadas, seria necessário aumentar a frequência utilizada e, com isso, a quantidade de energia fornecida ao sistema o que, por consequência, diminuiria a precisão na mensuração do momento linear da partícula. 
Portanto, o aumento da precisão na medição de uma variável, impacta produzindo aumento da incerteza sobre a outra, o que provoca uma ruptura com o causal. Sob esta concepção, a hipótese quântica se coloca de forma a configurar uma incerteza dos entes subatômicos (CHIBENI, 2005). Em decorrência desta particularidade, a descrição deste fenômeno ficou conhecida como princípio da incerteza de Heisenberg (BOHR, 1928; FEYNMAN; LEIGHTON; SANDS, 1966; HAWKING, 1988, 2001; CHIBENI, 2005). Em 1927 Heisenberg publicou os resultados desta perturbadora observação na Zeitschrift für Physik. Em seu artigo o autor descrevia que, apesar de desprezível no mundo macroscópico, as limitações experimentais levavam a grandes impactos no mundo subatômico (BUNGE, 1987).

Foi Niels Bohr quem construiu a interpretação que seria dominante na descrição da natureza da incerteza quântica - conhecida como interpretação de Copenhague (BUNGE, 1987). Na concepção de Bohr "[...] o postulado quântico implica que qualquer observação dos fenômenos atômicos irá envolver uma interação com o agente de observação que não pode ser negligenciada." ${ }^{22}$ (BOHR, 1928, p. 580, tradução nossa). Assim, a concepção da física atômica do autor, faz ruir a distinção entre objeto e a observação, proposta pela abordagem cartesiana. Para Bohr (1928, p. 580, tradução nossa) o problema da mecânica quântica "[...] atribui a qualquer processo atômico uma descontinuidade essencial, em vez da individualidade, completamente estranha às teorias clássicas [... $]^{\prime 23}$.

Nas palavras de Bunge (1987, p. 74) a interpretação de Copenhague mostra uma realidade onde:

[...] o que existe é uma unidade selada (composta de modo misterioso) pelo observador, seus meios de observação (instrumental) e o objeto de observação. A distinção entre os três componentes desse sistema não é inequívoca e objetiva, ficando ao arbítrio do sujeito, que pode incorporar o objeto ao aparelho ou considerar este último como um prolongamento de si mesmo. Portanto toda afirmação acerca de um micro-objeto deve referir-se também ao modo de observálo (BUNGE, 1987, p. 74).

$\mathrm{Na}$ interpretação de Copenhague, o ato de medir se torna um componente fundamental e indissociável do objeto, na compreensão do fenômeno quântico. Sob este ponto de vista, a observação é um componente capaz de perturbar a própria condição do

\footnotetext{
${ }^{22}$ Do inglês: "[...] The quantum postulate implies that any observation of atomic phenomena will involve an interaction with the agency of observation not to be neglected."

${ }^{23}$ Do inglês: "[...] attributes to any atomic process an essential discontinuity, or rather individuality, completely foreign to the classical theories [...]".
} 
objeto a que se propõem medir. Tal conjunção entre a observação e o objeto é amparada pelas próprias formulações matemáticas de Schrödinger, onde a potencialidade de um objeto só é revelada a partir do colapso da função de onda que, em última análise, decorre da observação (HAWKING, 1988; CHIBENI, 2005).

De acordo com a interpretação de Copenhague o problema quântico impõe limites ao conhecimento humano e dá ao instrumento de medição uma importância impar na construção da própria realidade experimental do mundo subatômico (HAWKING, 1988; CHIBENI, 2005). Portanto, esta ideia, de que é impossível projetar um equipamento para determinar simultaneamente o momento e a posição de uma partícula, é o pilar onde se estrutura a interpretação de Copenhague. Nesta concepção determinista, a problemática da física quântica remete a um questionamento de ordem epistemológica, já que nela, os limites para a compreensão do fenômeno estariam diretamente ligados à nossa própria incapacidade de conhecê-lo. Assim a física quântica estaria invariavelmente sujeita a uma problemática instrumental (FEYNMAN; LEIGHTON; SANDS, 1966).

Tomando por base a interpretação de Copenhague, Crema (1989, p. 43) afirma que "a espantosa constatação da Física subatômica, que exige uma total revisão da teoria do conhecimento tradicional, é a de que o observador influencia o fenômeno observado. Invalidando o ideal mítico de neutralidade na pesquisa científica [...]".

[...] É o ato de observação, em si, o que determina a transformação daquilo que é possível naquilo que é percebido como real; é ele quem seleciona entre uma infinidade de eventos possíveis, o evento real que ocorreu. Em suma, o observador modifica o fenômeno observado: não existe realidade observável independente da mente do observador. Constata-se uma unidade indissociável observadorobservado; e, mais significativamente ainda, reintroduz-se o sujeito no processo de observação científica [...]. (BAUER, 1999, p. 37)

Contudo, as discussões acerca do problema quântico ainda são controversas. Ilya Prigogine (1996), laureado com o prêmio Nobel de química em 1977 por seus trabalhos sobre as estruturas dissipativas, ressalta que, para os adeptos da interpretação de Copenhague, a indeterminação do problema quântico decorre da descontinuidade provocada pelo colapso da função de onda. No momento da observação, o estado do sistema quântico salta das múltiplas possibilidades, dadas pela amplitude da função de onda descrita pela equação de Schrödinger, para uma única possibilidade observada. Porém, Prigogine (1996) argumenta que a concepção do colapso da função de onda se configura em um paradoxo. Para o autor o observador não pode ser fundamental para a consolidação da 
realidade no mundo quântico pois, tendo o universo se iniciado em uma singularidade, seria necessário que alguém o tivesse medido em seus estágios iniciais - para que sua potencialidade se convertesse na atualidade que o compõe.

Uma das abordagens que dá conta deste questionamento é a escola do 'multiverso', proposta por Hugh Everett III em 1957. A escola do 'multiverso' prega que as possibilidades dadas pela função de onda - que descreve o comportamento incerto das partículas subatômicas - decorre da existência simultânea da partícula em um 'multiverso', composto por uma infinidade de universos paralelos emaranhados, os quais seríamos incapazes de observar. Assim, pela proposta da escola do 'multiverso' também seria impossível conhecer o estado da partícula a partir dos instrumentos contemporâneos, pois este estaria sujeito às interferências múltiplas e desconhecidas destes universos paralelos, os quais nossos utensílios não estariam preparados para medir (OSTERMANN; PRADO, 2005; MATTHEWS, 2008).

Nota-se similaridades de ordem epistemológicas entre a interpretação de Copenhague e interpretação do 'multiverso' já que ambas se referem a um problema de medição que impossibilitaria ao homem apreender a realidade livre da incerteza. Porém, cabe ressaltar que, apesar de ousada e eficaz ao lidar com o problema do observador, a interpretação do 'multiverso' se mostra menos coerente do que a interpretação de Copenhague, de acordo com o princípio lógico da navalha de Occam ${ }^{24}$.

Em uma abordagem mais elegante e, também, independente de pressupostos acerca da relação entre o observador e o objeto, Prigogine (1996) apresentou, em seu revolucionário trabalho sobre as estruturas dissipativas, uma formulação de características muito distintas das tentativas deterministas de explicar a mecânica quântica. Nela o autor também reconhece que a mecânica quântica trata-se de um problema de medida, assim como as proposições de outras escolas de pensamento da área. Contudo, no lugar de se utilizar de uma descrição clássica, o autor se utiliza de uma descrição estatística, que em muito faz lembrar as soluções adotadas pela termodinâmica.

\footnotetext{
${ }^{24}$ A navalha de Occam é um princípio lógico desenvolvido pelo frade inglês William de Occam no século XIV que defendia a simplicidade e a intuição como base primeira do conhecimento. Curiosamente este princípio se tornou um dos alicerces da ciência cartesiana e heurística. Sua principal implicação é que diante de duas ou mais explicações equivalentes para um fenômeno a melhor dentre elas é aquela que exige o menor número de premissas e entes para se sustentar (GLEISER, 2010).
} 
A abordagem de Prigogine (1996) consiste na incorporação das ressonâncias de Poincaré na descrição estatística da mecânica quântica. Basicamente o autor substituiu a função de onda $\Psi$, baseada nas amplitudes de probabilidade, pela própria probabilidade $\rho$ de uma medição. Sob esta concepção, os objetos quânticos deixam de ser tratados individualmente, como nas formulações clássicas, e passam a ser tratados como um conjunto de entes conjugados, que quando medidos individualmente oferecem valores aleatórios, mas quando medidos conjuntamente apresentam uma distribuição conforme a curva da função de onda (PRIGOGINE, 1996; CHIBENI, 2005).

Um aspecto importante da descrição de Prigogine (1996), é que "as partículas subatômicas não têm significado enquanto entidades isoladas, mas podem ser entendidas somente como interconexões, ou correlações, entre vários processos de observação e medida." (CAPRA, 2006, p. 41) Neste caso, os fenômenos quânticos não seriam mais descritos em termos de função de onda. Sob esta concepção, não há a figura do colapso da função de onda, onde a observação se faz fundamental para consolidação do estado quântico:

[...], mas o instrumento de medida deve satisfazer a um critério preciso: deve apresentar uma simetria temporal quebrada. [...] A condição necessária para nossa comunicação com o mundo físico, bem como para nossas comunicações com os outros humanos, é uma flecha comum do tempo, uma definição comum da distinção entre passado e futuro. (PRIGOGINE, 1996, p. 56)

A representação estatística da realidade quântica se dá, então, através de padrões de probabilidades de correlações que, em última instância, provocam uma ruptura da simetria temporal que impossibilita que se reverta determinados processos. Nesta condição se torna impossível conhecer a partir do presente, tanto o passado como o futuro com precisão. Sob esta concepção "as dificuldades epistemológicas da mecânica quântica estão, portanto, intimamente vinculadas ao problema do caos." (PRIGOGINE, 2002, p. 66)

Apesar desta descrição do fenômeno quântico não oferecer uma explicação do problema quântico, ela é tratada como uma das mais coerentes e bem estruturadas pela física moderna, pois em suas descrições matemáticas há uma independência dos aspectos relativos à natureza do objeto e às limitações experimentais. Isso a torna mais segura, uma vez que não envolve os problemas conceituais e filosóficos encontrados nas descrições deterministas e possibilita que se evite o problema da medição de duas grandezas conjugadas - momento e posição (CHIBENI, 2005). 
Gleiser (2010) ainda destaca que as assimetrias, como a assimetria do tempo proposta pela descrição estatística da física quântica, têm se confirmado não só no mundo subatômico, como também em outras descrições fundamentais do universo, como na expansão do cosmo, no desequilíbrio entre partículas e antipartículas e, até mesmo, na própria origem da vida. Destarte, a concepção de uma natureza imperfeita e criativa, como a da descrição estatística da física quântica, se mostra coerente com muitas das descobertas recentes da física moderna. Para o autor estas evidências tornam as assimetrias e, por consequência o problema do caos, componentes fundamentais a serem incorporados nos mais diversos aspectos das descrições da realidade.

Fica claro diante das variadas interpretações acerca do problema quântico, principalmente da descrição estatística, que este provocou uma ruptura com os princípios estritamente cartesianos e abriu espaço para uma nova abordagem epistemológica que teria impactos significativos sobre outras áreas do conhecimento (CAPRA, 1983; HAWKING, 1988). Conforme lembra Capra (1983) as descobertas do mundo quântico instituíram limites para o uso da visão clássica na descrição da realidade e com isso abriram uma perspectiva para os estudos da complexidade, uma vez que adicionou a interação entre a medição, os fatos e os resultados probabilísticos deste processo, na pauta do conhecimento científico.

A busca por uma compreensão maior acerca das incertezas, abriu as portas para novas formas de construção do conhecimento, onde o estático e o dinâmico, podem ser, na verdade, partes de uma única realidade que se estrutura a partir da interação entre os fatos e a forma com a qual os observadores os apreendem (CAPRA, 1983). Em outras palavras, a crise de percepção provocada pelo postulado quântico levou as ciências a vislumbrarem toda uma nova era de ideias, não no sentido de negar o permanente dos fatos, mas de adicionar um caráter integrativo e dinâmico à realidade. Esta nova realidade remete a uma volta ao ideal da mudança, já que o comportamento do ser subatômico não pode ser descrito em termos deterministas, devido aos limites impostos à capacidade de se conhecer o seu estado presente, sem que para isso se adicione incertezas com relação aos seus estados futuros. Ao final, o aspecto mais marcante desta revolução se resume às palavras do grande llya Prigogine (1996, p. 193): "vivemos o fim das certezas."

Estas novas concepções trouxeram consigo uma série de implicações profundas para as percepções humanas acerca do conhecimento. A física quântica despertou a ciência para uma perspectiva ontológica em que não se trata o ser como um objeto e sim como um ente 
conjugado, cuja existência real depende de suas relações. Devido à interdependência, o problema quântico ilustra um universo que se revela ao ser humano com um caráter transitório, onde o passado e o futuro não podem ser conhecidos, livres da incerteza.

As revoluções de ordem ontológica, epistemológica e metodológica, trazidas por esta nova ciência, levaram à ascensão de uma nova visão da realidade que "[...] se baseia na consciência do estado de inter-relação e interdependência essencial de todos os fenômenos [...]"25 (CAPRA, 1983, p. 265, tradução nossa). Em última instância, o novo espírito científico reconhece que "[...] não há partes, em absoluto. Aquilo que denominamos parte é apenas um padrão numa teia inseparável de relações." (CAPRA, 2006, p. 47).

\subsection{RUMO À COMPLEXIDADE}

Como visto anteriormente, o início do século $\mathrm{XX}$ trouxe as incertezas $\mathrm{e}$ as interconexões à pauta do conhecimento científico. Em um universo regido pela incerteza, oriunda das relações que se fortalecem com o passar da história, nem as abordagens clássicas e nem as concepções do segundo princípio da termodinâmica - que indicam que o caminho natural dos acontecimentos é a destruição e a desordem -, vinham se mostrando capazes de descrever o comportamento das entidades naturalmente organizadas. Isso acabou por despertar o interesse do meio científico pelo fenômeno da organização em sistemas ricamente interconectados. (PRIGOGINE, 1996; BERTALANFFY, 2009).

O problema da organização ganhou evidência a partir dos estudos sobre a vida, mais especificamente dos trabalhos do biólogo Ludwig Von Bertalanffy, na década de 1950. Após estabelecer as ideias do pensamento processual, durante a década de 1930, Bertalanffy observou que os entidades constituídas por meio da interação entre agentes, produziam

${ }^{25}$ Do inglês: "[...] is based on awareness of the essential interrelatedness and interdependence of all phenomena $[\ldots]$ ". 
dinâmicas diferentes daquelas obtidas por meio do estudo de seus componentes separados. Com base nesta concepção, o autor propôs que a ciência deveria se preocupar com o movimento transformador e auto-organizante das relações complexas às quais os componentes dos sistemas encontrar-se-iam submetidos (CAPRA, 2006; CASANOVA, 2006; BERTALANFFY, 2009).

Bertalanffy adotou, então, o termo "sistema" para descrever este tipo de entidade composta por unidades interligadas, cuja organização seria o elemento chave de sua dinâmica - os critérios que permitem distinguir um sistema são dados no quadro 1. Esta concepção se tornou, então, o alicerce daquela que ficou conhecida como "Teoria dos Sistemas" (CAPRA, 1983; BUNGE, 1987; CAPRA, 2006).

\section{Critérios para reconhecer um sistema}

- Um sistema comporta-se como um todo, ou seja, "possui leis próprias enquanto totalidade."

- Um sistema muda de comportamento quando algum de seus componentes é retirado ou modificado.

Quadro 1 - Critérios para reconhecer um sistema Adaptado de: Bunge (1987, p. 90)

A ideia central por trás da Teoria dos Sistemas é que os sistemas só podem ser entendidos como totalidades integradas, cujas partes ou componentes se relacionam de tal forma que não podem ser reduzidos a unidades menores, sem que percam suas propriedades (CAPRA, 1983; BUNGE, 1987; CAPRA, 2006). Em outras palavras, "[...] o pensamento sistêmico concentra-se não em blocos de construção básicos, mas em princípios de organização básicos." (CAPRA, 2006, p. 41) Deste modo, pode-se dizer que para a teoria dos sistemas:

[...] a natureza é vista como uma teia interconexa de relações, na qual a identificação de padrões específicos como sendo "objetos" depende do observador humano e do processo de conhecimento. Essa teia de relações é descrita por intermédio de uma rede correspondente de conceitos e de modelos, todos igualmente importantes. (CAPRA, 2006, p. 49) 
A princípio, as concepções da teoria dos sistemas se basearam nos conceitos de uma disciplina estruturada sobre preceitos cartesianos, denominada de Cibernética (PIERCE, 1980; BAUER, 1999; MORIN, 2007c; BERTALANFFY, 2009). A palavra Cibernética vem do grego kybernetes, cujo significado é timoneiro. O objetivo central por trás desta disciplina era a construção de dispositivos de controle capazes de regular, por meio do processamento de informações e da comunicação, o comportamento de um determinado sistema, assim como os timoneiros fazem ao controlar um navio (PIERCE, 1980; CAPRA, 2006). Sua base reside nos esforços pioneiros de nomes como John Von Neumann e Norbert Wiener, cujas ideias se propagaram durante a segunda guerra mundial, a partir de seu uso como instrumento para construção de aparatos de guerra autogovernados (PIERCE, 1980; BAUER, 1999; MORIN, 2007c; BERTALANFFY, 2009).

Uma particularidade da Cibernética, que afeta todo o pensamento sistêmico, é que as explicações no âmbito cibernético são sempre negativas, diferente da explicação causal aplicada pelo pensamento cartesiano, que normalmente é de âmbito positivo. Sobre uma perspectiva causal a explicação se dá no sentido dos acontecimentos, busca-se uma relação direta entre causa e efeito. Em uma perspectiva cibernética volta-se às probabilidades de ocorrência entre diversas possibilidades. Dentre as alternativas possíveis, o pesquisador cibernético analisa porque uma alternativa foi seguida pelo sistema em detrimento de outra e com isso se estabelecem as restrições que levaram o fenômeno a se desenvolver daquela maneira (BATESON, 1967).

A contribuição da cibernética que seria uma base importante para grande parte do conhecimento sistêmico, é aquela que se refere aos laços de realimentação. A ideia dos laços de realimentação é o alicerce dos mecanismos de auto-regulação, responsáveis pela manutenção da estabilidade dinâmica em sistemas distantes do equilíbrio, assim como os seres vivos. Os laços de realimentação têm implicações importantes para o estudo dos sistemas, pois este tipo de recursividade é um componente fundamental para manutenção da ordem em sistemas dinâmicos ricamente interligados (BERTALANFFY, 2009).

Um exemplo de laço de realimentação pode ser encontrado na própria atividade de um timoneiro - ver figura 4. A atividade de um timoneiro é uma atividade contínua e circular onde, a princípio, o timoneiro avalia a rota da embarcação e ao constatar algum tipo de desvio o timoneiro esterça o navio para corrigir o desvio. Isso provoca uma mudança no curso da embarcação que impacta diretamente sobre a avaliação da rota e assim 
sucessivamente. $\mathrm{Na}$ linguagem cibernética este tipo de dispositivo “[...] que age continuamente, com base na informação para atingir um objetivo diante da mudança é chamado de servomecanismo." ${ }^{26}$ (PIERCE, 1980, p. 215, tradução nossa)

"Quando existe esta circularidade de ação entre as partes de um sistema dinâmico, pode-se afirmar que há realimentação (feedback)." (ASHBY, 1970, p. 63) Em um sistema composto por laços de realimentação "[...] uma causa inicial se propaga ao redor das articulações do laço, de modo que cada elemento tenha um efeito sobre o seguinte, até que o último "realimenta" (feeds back) o efeito sobre o primeiro elemento do ciclo." (CAPRA, 2006, p. 59)

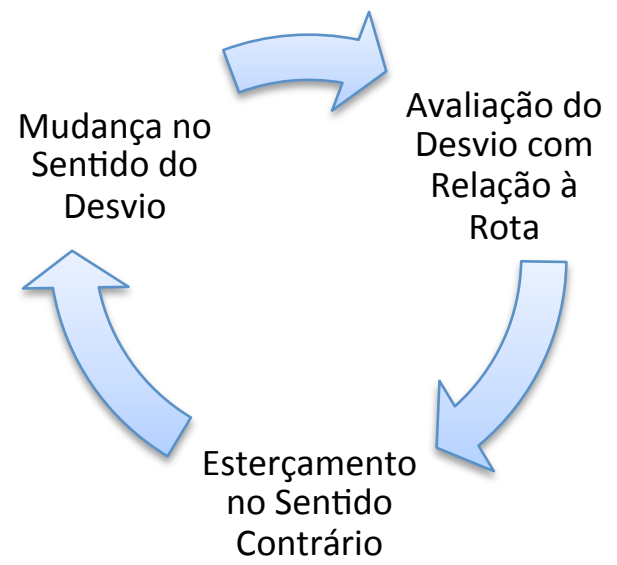

Figura 4 - Laço de realimentação representando a pilotagem de um barco. Fonte: Capra (2006, p. 60)

A concepção cibernética de laço de realimentação possui implicações importantes, ao passo que permite a compreensão da dinâmica das máquinas autogovernadas e rompe com os preceitos de causalidade linear, defendidos pelo ponto de vista cartesiano. Isso porque os sistemas que apresentam feedback podem incorporar não só sinais externos, mas também os resultados de sua própria saída - ver figura 5. Desse modo, este tipo de sistema apresenta uma causalidade recursiva, na qual as respostas atuam, também, como estímulos para novas interações.

\footnotetext{
${ }^{26}$ Do inglês: "[...] which acts continually on the basis of information to attain a specified goal in the face of changes is called a servo-mechanism."
} 


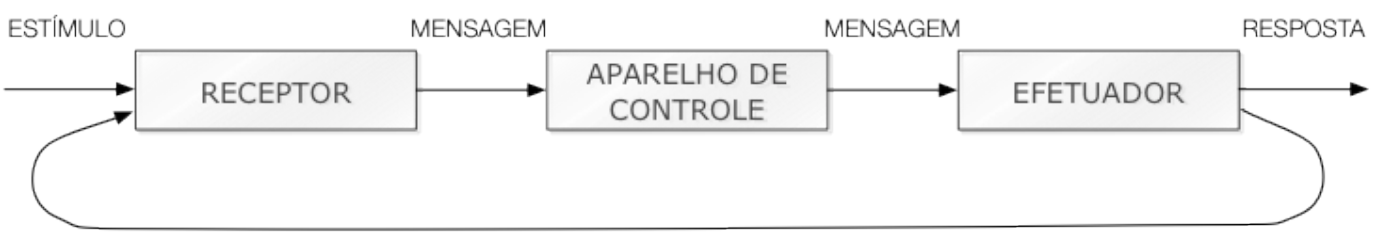

Figura 5 - Esquema básico da realimentação.

Fonte: Bertalanffy (2009, p. 209)

A não-linearidade em sistemas dotados de feedback pode ser encontrada mesmo em sistemas bastante simples. Como exemplo, pode-se tomar um sistema sem feedback, no qual a saída do aparelho de controle é dada por $f(x)=2 x$, onde $x$ é um estímulo recebido de valor 1 por período. Este sistema se apresenta com um comportamento linear, de acordo com os preceitos de causalidade cartesianos, onde a saída será sempre 2. Contudo, ao submeter à mesma função um sistema com o mesmo estímulo constante igual a 1 por período e dotá-lo de um feedback que adiciona sua própria saída ao estímulo, este apresentará como resultado um comportamento não-linear, cujo resultado diverge rapidamente do estado inicial - ver tabela 1 e gráfico 1.

\begin{tabular}{ccc}
\hline \multirow{2}{*}{ Período } & \multicolumn{3}{c}{ Saídas } \\
\cline { 2 - 3 } & Sistema com Feedback & Sistema sem Feedback \\
\hline 1 & 2 & 2 \\
\hline 2 & 6 & 2 \\
\hline 3 & 14 & 2 \\
\hline 4 & 30 & 2 \\
\hline 5 & 62 & 2 \\
\hline
\end{tabular}

Tabela 1 - Evolução de sistemas com e sem feedback, alimentados por uma entrada constante igual a 1, onde a saída é dada por uma função $f(x)=2 x$

Fonte: Elaborada pelo autor

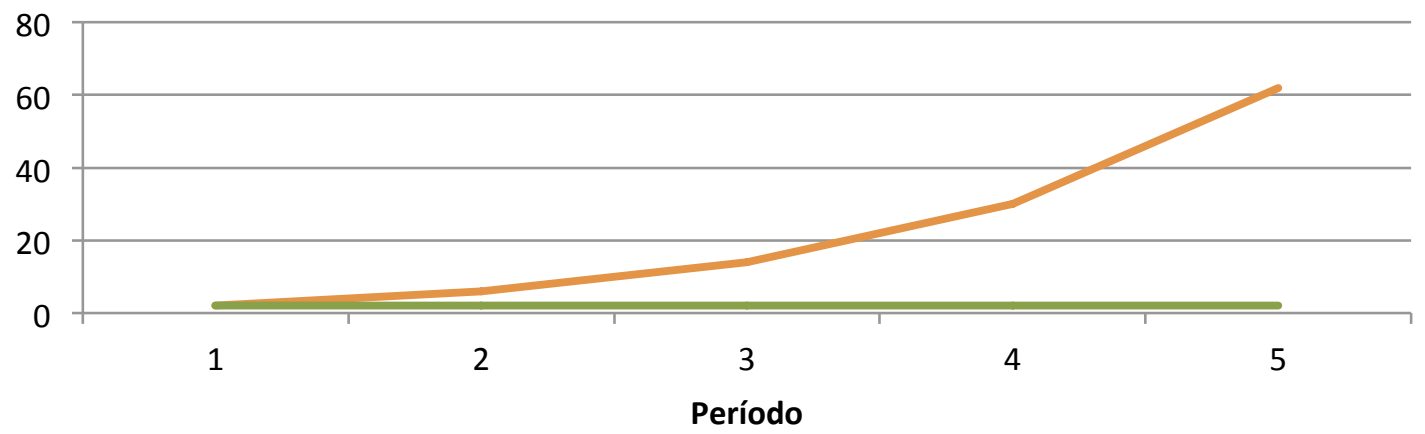

Sistema com Feedback $\quad$ Sistema sem Feedback

Gráfico 1 - Evolução de sistemas com e sem feedback, alimentados por uma entrada constante igual a 1, onde a saída é dada por uma função $f(x)=2 x$

Fonte: Elaborado pelo autor 
A principal implicação dos laços de alimentação, em termos epistemológicos, consiste no fato de que os sistemas com conexão em teia exigem uma modelagem matemática nãolinear que, em última instância, pode conduzir à incerteza e ao indeterminismo (CAPRA, 2006). Neste sentido, Bateson (1967) ilustra as implicações deste fenômeno, por meio de uma metáfora comparando a reação de uma bola de bilhar e de um cachorro a um chute. Conforme explana o autor, a resposta de uma bola de bilhar a um chute será linear, dada de acordo com a terceira lei do movimento de Newton, enquanto o comportamento do cachorro será proporcional à energia que este mesmo se prontificar a disponibilizar para tal. Portanto, o cachorro apresentará uma resposta não-linear que irá derivar, não só do estímulo externo, como de um conjunto de respostas do próprio sistema, ou seja, será uma resposta autogovernada. Assim, pode-se dizer que os laços de realimentação estabelecem uma relação de causalidade circular que está por trás do conceito de auto-regulação da cibernética. Neste cenário, a ruptura com determinismo se faz fundamental para unificar a criatividade humana com a natureza (PRIGOGINE, 1996).

"Quando os fenômenos do universo são vistos como interligados entre si, por transferência de energia e relações de causa e efeito, a imagem resultante é a de cadeias de causalidade complexamente ramificadas e interconectadas."27 (BATESON, 1967, p. 30, tradução nossa) Os sistemas com este formato são capazes de criar múltiplos laços de realimentação, que os tornam mais enredados e é desta perspectiva que surge o conceito de complexidade.

\footnotetext{
Um sistema complexo é definido como uma unidade pelas relações entre seus componentes que torna real o sistema como um todo, e suas propriedades como uma unidade são determinadas pela forma como esta unidade é definida, e não por propriedades particulares dos seus componentes.[...] Destarte, a mesma organização pode ser realizada em diferentes sistemas com diferentes tipos de componentes, desde que estes componentes tenham propriedades que lhes permitam realizar as relações necessárias. ${ }^{28}$ (VARELA; MATURANA; URIBE, 1974, p. 188, tradução nossa)
}

\footnotetext{
${ }^{27}$ Do inglês: "When the phenomena of the universe are seen as linked together by couse-and-effect and energy transfer, the resulting picture is of complexly branching and interconnecting chains of causation."

${ }^{28}$ Do inglês: "A complex system is defined as a unity by the relations between its components which realize the system as a whole, and its properties as a unity are determined by the way this unity is defined, and not by particular properties of its components. [...] Accordingly, the same organization may be realized in different systems with different kinds of components as long as these components have the properties which realize the required relations."
} 
Portanto, diante da complexidade "[...] a mudança sistêmica não é um fenômeno mecanicista, progressivo e linear onde causas e efeitos podem ser claramente isolados." ${ }^{29}$ (JAAFARI, 2003, p. 47, tradução nossa). Nos sistemas complexos as relações ganham uma dimensão tal que um sistema se torna permeado por um número demasiadamente grande de interações e interferências que definem o próprio comportamento do sistema como um todo (MORIN, 2007c). Mesmo com os sistemas complexos podendo ser governados por padrões relativamente simples, quando combinados estes sistemas podem "[...] gerar uma variedade infinita". (PASCALE, 2002, p. 123) Portanto, a compreensão dos sistemas complexos só faz sentido se estes forem tratados a partir de sua totalidade (ASHBY, 1970).

Neste ponto, é importante destacar que a concepção integrativa da complexidade implica em um problema epistemológico, semelhante ao encontrado na física quântica. Qualquer tentativa de se conhecer a dinâmica de um sistema acoplado ao restante do universo exige, ao mesmo tempo, o conhecimento deste sistema e do universo por inteiro, para que nenhuma relação escape ao observador. Nestas condições, a certeza exige, no mínimo, os conhecimentos e os poderes de cálculo ilimitados do intelecto superior proposto por Laplace (1829). Contudo, os limites para o processamento e transmissão de dados, impostos pela teoria da informação (SHANNON, 1948; PIERCE, 1980), e as novas teorias acerca da apropriação de informações por parte dos buracos negros (HAWKING, 1988), mostram que mesmo diante de uma abordagem determinista, a possibilidade de existência de tal ser é, no mínimo, pouco realista.

Desse modo, a complexidade deseja chegar a completude, mas ela não pode escapar às incertezas, já que a própria concepção de complexidade, assim como a física quântica, ilustra que um saber total não pode ser atingido (MORIN, 2007c). Portanto “ [...] a complexidade não irá trazer certezas sobre o que é incerto; ela pode apenas propor-se a reconhecer a incerteza, e a dialogar com ela." (BAUER, 1999, p. 19) Pode-se dizer, então, que “[...] o desafio da complexidade reside no duplo desafio da religação e da incerteza. [...] É preciso aprender a fazer com que as certezas interajam com a incerteza." (MORIN, 2007b, p. 63) Mas não se pode esquecer que "[...] a complexidade não se reduz à incerteza, é a incerteza no seio de sistemas ricamente organizados." (MORIN, 2007c, p. 35)

\footnotetext{
${ }^{29}$ Do inglês: "The science of complexity has shown that systemic change is not a mechanistic, progressive, and linear phenomenon whose causes and effects can be clearly isolated"
} 
Os sistemas complexos podem contemplar diversos subsistemas que possuem uma dinâmica com propriedades emergentes, referentes ao vínculo entre seus subsistemas, que por sua vez contêm as propriedades oriundas das conexões de seus respectivos subsistemas e assim sucessivamente. Esta propriedade possibilita que fenômenos de diversas áreas do conhecimento, pertençam a diferentes níveis sistêmicos, onde os níveis mais complexos compreendem as propriedades de seus subsistemas, adicionadas de particularidades de suas próprias estruturas de acoplamento - ver figura 6 - (CAPRA, 1983; BUNGE, 1987; BAUER, 1999).

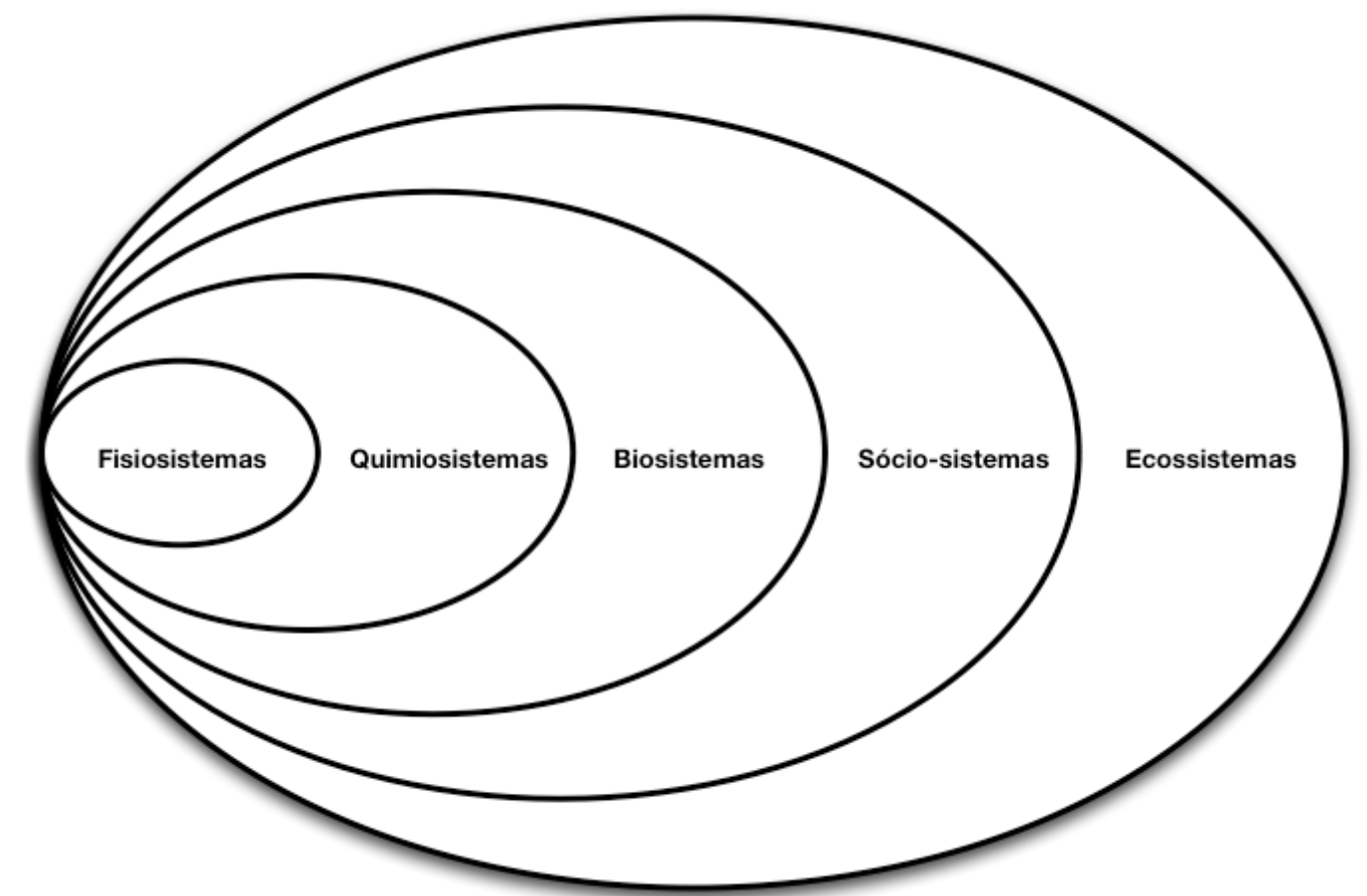

Figura 6 - Propriedades compartilhadas entre os níveis sistêmicos Adaptada de: Capra (1983), Bunge (1987) e Morin (2007c)

Conforme destaca Morin (2007b, p. 18) este aspecto da complexidade é especialmente inquietante diante de uma ciência construída a partir do reducionismo cartesiano, pois a "[...] separação e fragmentação das disciplinas é incapaz de captar 'o que está tecido em conjunto', isto é, o complexo, segundo o sentido original do termo." Isso porque os:

[...] níveis diferentes correspondem a campos diferentes de conhecimento. Suas técnicas e suas dissertações são diferenciados e eles não se tocam em seus limites, onde são articulados separadamente. Dispomos apenas de alguns meios bastante 
limitados para falar sobre estas articulações porque elas surgem entremeadas nos diferentes campos do conhecimento científico e, portanto, não podemos ter acesso direto a eles. (ATLAN, 2001, p. 117)

Portanto, o pensamento a partir da complexidade exige uma ruptura com o ideal das disciplinas. Diante da complexidade, as barreiras entre as ciências, impostas pela fragmentação do pensamento cartesiano, precisam ser rompidas através de uma reforma no próprio pensamento científico (CAPRA, 2006; CASANOVA, 2006). Mas é importante ressaltar que a ideia central do ponto de vista da complexidade não consiste na negação do que foi produzido pelas disciplinas, "se todas as coisas são causadas e causantes, ajudadas e ajudantes, mediatas e imediatas e mantidas por uma ligação material e insensível que as sujeitam, torna-se impossível conceber as partes sem conceber o todo e tampouco o todo sem conceber as partes." (MORIN, 2007b, p. 22)

Desse modo, a complexidade se mostra muito ligada aos ideais sistêmicos, propostos por Bertalanffy (2009). De acordo com este ponto de vista, o conhecimento deve ser apreendido em um ciclo que iria da parte ao todo e do todo à parte, a partir do estudo entre as interações dinâmicas dos fenômenos - ver figura 7. Sob as concepções sistêmicas, a construção do conhecimento deve se valer de elementos da reflexão teórica, experimental e empírica, em estágios que vão do plano dos fragmentos ao plano da totalidade, com o objetivo de distinguir os níveis de escala e generalização ligados ao fenômeno (CASANOVA, 2006; BERTALANFFY, 2009).

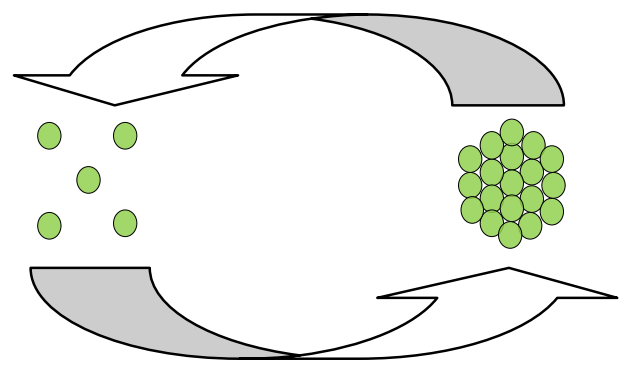

Figura 7 - Ciclo de apreensão do conhecimento segundo o pensamento sistêmico Adaptada de: Morin (2007a, p. 259)

Em síntese, pode-se dizer que, para Bertalanffy:

“[...] a chave para uma teoria abrangente dos sistemas vivos está na síntese dessas duas abordagens muito diferentes: o estudo da substância (ou estrutura) e o estudo da forma (ou padrão). No estudo da estrutura, medimos ou pesamos coisas. 
Os padrões, no entanto, não podem ser medidos nem pesados; eles devem ser mapeados." (CAPRA, 2006, p. 77)

No ser humano, o mapeamento dos padrões é controlada pelo hemisfério direito do cérebro que tem como mecanismo de apreensão da realidade a intuição. Já os sentidos, utilizados pelo empirismo das abordagens cartesianas, se prendem ao detalhamento da substância e ao formalismo - vinculados ao hemisfério esquerdo do cérebro. Enquanto a propriedade das partes é apreendida por meio das atividades do hemisfério cerebral esquerdo que, por meio da sensação e da cognição, é capaz de apreender a existência do objeto, descrevê-lo e classificá-lo, a síntese da totalidade é dada pela intuição que, de forma inconsciente, percebe o quadro completo a partir das possibilidades que se apresentam (JUNG, 1971; CREMA, 1989). Tal percepção vai ao encontro do que defende Capra (2006), para quem a intuição é um componente chave para construção de um paradigma de caráter integrativo.

Desse modo, o pensamento sistêmico não pode ser tratado nem como holismo e nem como reducionismo, ao passo que não olha nem totalmente do alto e nem totalmente de baixo. Assim como uma abordagem exclusivamente sensorial e lógica - como o reducionismo - pode levar ao desconhecimento do todo, uma abordagem puramente intuitiva e sentimental - como a do holismo - pode levar a mística, já que é impossível organizar e definir o que é real nas construções do hemisfério direito, sem submeter seus resultados ao escrutínio do hemisfério esquerdo do cérebro humano (CREMA, 1989).

Pode-se dizer, então, que os ideais da complexidade apontam para uma concepção metodológica capaz de lidar com o problema da interligação, já que o cartesianismo leva a uma hipertrofia da importância dos aspectos do hemisfério esquerdo do cérebro, enquanto o holismo, por sua vez, leva a uma hipertrofia da importância dos aspectos do hemisfério direito. Portanto, para a compreensão sistêmica é necessário que haja uma real integração entre as atividades de ambos os hemisférios cerebrais (CREMA, 1989), assim como prega o próprio ideal da complexidade. Destarte, para a compreensão a partir de uma perspectiva sistêmica é necessário compor métodos que se baseiem tanto nas sínteses da intuição, como também na dedução lógica, necessária para classificar e depurar os conteúdos destas apreensões intuitivas.

Por ser ao mesmo tempo integradora e desintegradora, a complexidade requer, ao mesmo tempo, uma postura intuitiva e racional. Ela exige tanto a intuição totalizante, o 
simbolismo e a capacidade de reconhecer padrões, do hemisfério direito do cérebro, como a atividade lógica e a capacidade de comparação e de classificação do hemisfério esquerdo. Assim, pode-se dizer que a complexidade é conciliadora, ela não favorece nenhum dos aspectos que compõem as habilidades mentais do ser humano, pelo contrario, exige métodos que consigam articular e usufruir de ambos os hemisférios cerebrais.

A complexidade precisa, então, combinar, de forma sintética, os relacionamentos entre a ordem e a desordem. Neste contexto "o pensamento complexo não recusa de modo algum a clareza, a ordem, o determinismo. Ele os considera insuficientes, sabe que não se pode programar a descoberta, o conhecimento nem a ação." (MORIN, 2007c, p. 83) Em sua essência, a complexidade difere do paradigma reducionista, que sustenta o ideal cartesiano de ciência, ao contemplar também as relações que eram deixadas à margem do conhecimento, neste ponto de vista. Foi desta diferença essencial que nasceu um novo paradigma para a ciência, cuja síntese, em comparação às abordagens reducionistas, pode ser vista no quadro 2.

\begin{tabular}{lcc} 
& & Paradigma \\
& Reducionismo & Complexidade \\
\hline Foco de estudo & Objetos & Relações \\
Sujeito/Objeto & Dissociáveis & Indissociáveis \\
Preceito & Desintegração & Integração $\Leftrightarrow$ Desintegração \\
Hemisfério cerebral dominante & Esquerdo & Direito $\Leftrightarrow$ Esquerdo \\
Conhecimento & Sensorial & Intuitivo \\
Inferência predominante & Indutiva & Dedutiva \\
Causalidade & Linear & Recursiva \\
Modelos & Lineares & Não-lineares \\
Linguagem & Formal/Matemática & Simbólica
\end{tabular}

Quadro 2 - Diferenças entre as abordagens do reducionismo cartesiano e do paradigma da complexidade Fonte: Elaborado pelo autor.

Destarte, o século $X X$ trouxe grandes avanços para o pensamento e a percepção humana acerca da realidade. Os três pilares das ciências até então (determinismo, separabilidade e prova absoluta):

[...] encontram-se hoje em estado de desintegração, não porque a desordem substituiu a ordem, mas porque começou-se a admitir que, mesmo no mundo físico em que a ordem reinava soberana, existia na realidade um jogo dialógico entre ordem e desordem simultaneamente complementar e antagônico. (MORIN, 2007b, p. 61) 
A compreensão da complexidade oferece, portanto, "[...] uma nova vida aos métodos experimentais e à construção de teorias de conjuntos e subconjuntos articulados." (CASANOVA, 2006, p. 36) 



\section{AS MÚLTIPLAS PERSPECTIVAS DA ESTRATÉGIA}

A palavra estratégia vem da palavra grega strategos, que designava o papel de um general no comando de seu exército (GHEMAWAT, 2000; QUINN, 2003). Tanto as escolas militares clássicas, representadas por Péricles e Alexandre, como as escolas da antiguidade oriental, representadas por Sun Tzu, possuíam uma abordagem da estratégia como um conjunto de artimanhas para subjugar os adversários, através do domínio sobre os cenários e os componentes do exército. Com o passar do tempo a estratégia passou a ser associada às habilidades inerentes ao cargo dos generais, como liderança, poder, oratória e as habilidades administrativas (TZU, 1983; GHEMAWAT, 2000; QUINN, 2003).

"O conceito de estratégia, a princípio utilizado apenas por organizações militares, foi posteriormente apropriado pelo ambiente de negócios [...]" (LOBATO et al., 2007, p. 15). Os fundamentos desta transposição foram plantados em 1912, quando a Harvard Business School introduziu em seu currículo uma disciplina denominada "Política de negócios", cujo objetivo era integrar as diversas áreas de conhecimento em administração. Durante a década de 1960, as abordagens militares, desenvolvidas na segunda guerra mundial, e a análise de cenários externos, foram adicionadas aos aspectos internos estudados pela "Política de Negócios". Este processo formalizou a presença da estratégia no cenário corporativo (ANSOFF; HAYES, 1981; MINTZBERG; AHLSTRAND; LAMPEL, 1998; HUNGER; WHEELEN, 2002; WRIGHT; KROLL; PARNELL, 2007).

Com o tempo, a questão tratada por esta nova linha de pesquisa, que Ansoff e Hayes (1981) denominaram de problema estratégico, ganhou três dimensões, representativas de seus aspectos principais: os problemas internos e externos, suscitados pela situação, os processos de solução destes problemas e as variáveis que os compõem. A partir disso, a disciplina evoluiu para integrar estas três dimensões e consolidar o que os pesquisadores da área passaram a denominar de "Administração Estratégica" (ANSOFF; HAYES, 1981; MINTZBERG; AHLSTRAND; LAMPEL, 1998; HUNGER; WHEELEN, 2002; WRIGHT; KROLL; PARNELL, 2007). Das três dimensões propostas por Ansoff e Hayes (1981), sem dúvida, uma 
das melhor exploradas pelas escolas contemporâneas de gestão é a que se refere aos processos utilizados para a solução dos problemas internos e externos.

Mintzberg, Ahlstrand e Lampel (1998) afirmam que durante as últimas décadas os mais diversos autores tocaram os aspectos mais profundos da estratégia, porém sem consolidar uma reflexão teórica capaz de descrever a essência por trás da mesma. Se apropriando de uma metáfora utilizada pelos autores, os pesquisadores da área da estratégia ainda estão tateando um grande elefante, a fim de conhecer suas partes, porém ainda estão impossibilitados de identificar os aspectos que definem este grande animal (MINTZBERG; AHLSTRAND; LAMPEL, 1998). Esta situação cria dificuldades dentro da própria área acadêmica, onde as dificuldades semânticas são enormes. "Há dezenas de definições para os conceitos principais e vários conceitos, introduzidos nos anos recentes, como visão estratégica, pensamento estratégico, estratégia emergente etc., sobre os quais há discordâncias." (BETHLEM, 2001, p. 18)

Autores como Lobato et al. (2007), Ghemawat (2000), Mintzberg (1987b) e Mintzberg, Ahlstrand e Lampel (1998) reconhecem a importância da multiplicidade de pontos de vistas e buscam investigar as diversas abordagens acerca do problema, em busca de elementos em comum que possam unificar os conceitos a respeito da estratégia. Neste sentido, os trabalhos que mais se destacam são os de Mintzberg, Ahlstrand e Lampel (1998) e Mintzberg e Lampel (1999), por sua profundidade e especificidade sobre o tema. Os autores construíram uma imagem do que denominaram de "fera da estratégia", a partir da compilação de mais de duas mil obras da literatura, e como resultado obtiveram o mais amplo retrato do processo estratégico.

\subsection{DOIS EIXOS PARA A ESTRATÉGIA}


Até hoje, o sentido militar do termo estratégia é o mais difundido nos meios populares. No Moderno Dicionário da Língua Portuguesa - Michaelis, a palavra estratégia é definida como: "1 Arte de conceber operações de guerra em planos de conjunto. 2 Ardil, manha, estratagema. 3 Arte de dirigir coisas complexas." Sentido semelhante é encontrado no le-dictionnaire que afirma que estratégia é "[...] a arte de combinar e coordenar as ações diferentes para alcançar um objetivo, principalmente para os militares, a arte de coordenar todas as forças de um país envolvido." ${ }^{30}$ Já no Cambridge Advanced Learner's Dictionary, encontra-se também uma definição de estratégia como um plano aplicável, tanto em situações políticas e de guerra, como para outras áreas como negócios ou esportes.

Além das definições de estratégia como um estratagema, adotada pelas escolas militares, e como plano, Minzberg (2003b) identificou, em seus esforços para conhecer as múltiplas facetas da estratégia, outros três significados para o termo. Segundo o autor a estratégia também pode ser tratada como uma posição, como uma perspectiva ou como um padrão de comportamento organizacional.

Wright, Kroll e Parnell (2007), Almeida (2001) e Hunguer e Wheelen (2002), são exemplos de autores da área que adotam a definição de estratégia como um plano. Nas perspectivas destes autores a estratégia consiste em um programa para guiar a organização por uma determinada rota que proporcione estabilidade e vantagem competitiva para o futuro da organização (MINTZBERG; AHLSTRAND; LAMPEL, 1998; HUNGER; WHEELEN, 2002). Porém, Mintzberg Ahlstrand e Lampel (1998) lembram que a realização bem sucedida de um conjunto de planos com foco no futuro depende, em última instância, de previsões que dificilmente possuem a precisão necessária para conduzir a organização em direção aos seus objetivos de longo prazo.

Neste sentido, Valle et al. (2007), ressalta que nestas condições o planejamento estratégico exige constante monitoramento e controle para permanecer aderente ao ambiente. Este processo contínuo de planejamento, monitoramento e controle das estratégias é o que autores como Wright, Kroll e Parnell (2007) denominam de “Administração Estratégica". Nas palavras dos autores, a "Administração Estratégica" incorpora o:

30 Do francês: “[...] art de combiner et de coordonner diverses actions pour atteindre un but et particulièrement pour le domaine militaire, art de coordonner toutes les forces d'un pays engag." 
“[...] processo contínuo de determinação da missão e objetivos da empresa no contexto de seu ambiente externo e de seus pontos fortes e fracos internos, formulação de estratégias apropriadas, implementação dessas estratégias e execução do controle para assegurar que as estratégias organizacionais sejam bem sucedidas quanto ao alcance dos objetivos." (WRIGHT; KROLL; PARNELL, 2007, p. 45)

Os defensores da estratégia como um plano argumentam que o processo de "Administração Estratégica" e seus ciclos bem estruturados de mensuração e controle, seriam suficiente para suprir as dificuldades inerentes ao planejamento de longo prazo, levantadas por Mintzberg Ahlstrand e Lampel (1998). Esta concepção de gestão contínua dos planos, seria capaz sustentar o planejamento diante das transformações do ambiente, já que contemplariam os aspectos dinâmicos necessários para os planos possam ser constantemente adaptados à situação. Em síntese, para o grupo de autores que adotam tal definição, a estratégia consiste em um plano com foco no futuro que, devido às dificuldades inerentes à transformação do ambiente, precisa ser administrado continuamente para se adaptar a novas realidades às quais as organizações podem se encontrar submetidas.

Apesar desta concepção ainda ser um ponto de vista fortemente enraizado nos meios de gestão, Mintzberg (1987a, 2003a) desenvolveu uma concepção de estratégia sustentada tanto na ideia do planejamento e controles deliberados, como em seu antagônico, a emergência de comportamentos espontâneos na própria operação das organizações. Em essência, Mintzberg (1987a, 2003a) defende que a "estratégia é um padrão, isto é, consistência no comportamento ao longo do tempo." ${ }^{31}$ (MINTZBERG; AHLSTRAND; LAMPEL, 1998, p. 9, tradução nossa)

Para os adeptos da definição de Mintzberg (1987a, 2003a), a estratégia não olha para o futuro e sim para o passado, já que ela se trata da consistência percebida naquilo que foi previamente realizado pela organização. Diante de tal concepção não importa se a estratégia foi deliberada a partir de um plano ou simplesmente deriva do comportamento organizacional. Portanto, "uma organização pode ter um padrão (ou estratégia realizada) sem saber que o tem."32 (MINTZBERG, 2003a, p. 67, tradução nossa)

Esta visão de estratégia como um padrão leva à percepção que uma organização pode ter estratégias que emergem de sua própria condição operacional. Nas estratégias emergentes "[...] os agentes agiriam improvisando em função das circunstâncias."

\footnotetext{
${ }^{31}$ Do inglês: "Strategy is a pattern, that is consistency in behavior over time.

32 Do inglês: "An organization can have a pattern (or realized strategy) without knowing it [...]."
} 
(MINTZBERG, 1987a; BETHLEM, 2001, p. 19) Com o passar do tempo estas "ações simplesmente se convertem em padrões" ${ }^{33}$ que, em última instância, se associam com as estratégias deliberadas e compõem a estratégia realizada pela organização - ver figura 8 (MINTZBERG, 2003a, p. 69, tradução nossa).

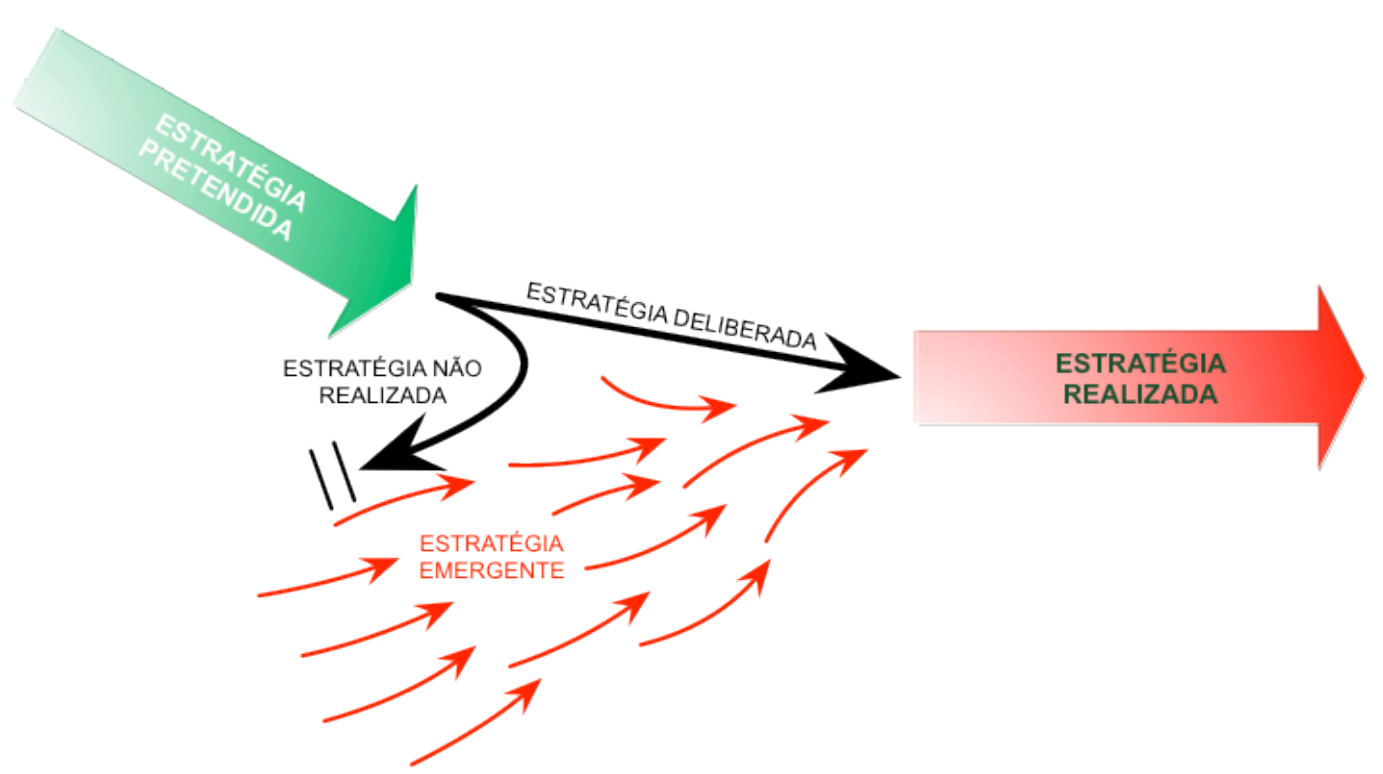

Figura 8 - Dinâmica que origina as estratégias realizadas pela organização. Fonte: Mintzberg (2003b, p. 14, tradução nossa).

As mudanças no ambiente interno e externo podem levar as estratégias pretendidas e deliberadas a não serem realizadas, enquanto padrões de comportamento emergem constituindo um padrão para a organização que é fruto tanto do que persiste da estratégia deliberada, como dos padrões de comportamento emergentes (MINTZBERG, 1987b, a; MINTZBERG; AHLSTRAND; LAMPEL, 1998; WRIGHT; KROLL; PARNELL, 2007). Mintzberg (2003a, p. 67, tradução nossa) ainda ressalta que, tendo por base esta concepção, "a definição formal de estratégia e sua origem militar não sobrevive, nós precisamos da palavra tanto para explicar ações passadas como para descrever o comportamento pretendido." ${ }^{34}$ Destarte, a estratégia como um padrão leva a uma condição onde, "o chamado planejamento estratégico deve ser reconhecido pelo que é: um meio, não para criar

\footnotetext{
33 Do inglês: "Actions simple converge into patterns."

${ }^{34}$ Do inglês: "Strategy's formal definition and its Greek military origins not withstanding, we need the word as much to explain past actions as to describe intended behavior."
} 
estratégia, mas para programar uma estratégia já criada - para trabalhar com suas implicações formalmente." ${ }^{35}$ (MINTZBERG, 2003a, p. 73, tradução nossa)

O reconhecimento das estratégias emergentes, como componente importante da estratégia, teve implicações importantes nos campos de estudo da estratégia, mais precisamente no que se refere ao estudo do problema da estratégia frente aos cenários submetidos a rápidas transformações. Autores como Hamel (2002) e Hunger e Wheelen (2002) adotaram tal definição, que passa pelo reconhecimento das estratégias emergentes e ressalta a importância para a organização de explorar o aprendizado e os aspectos comportamentais da mesma. Com isso, estes destacaram que a flexibilidade necessária para lidar com o ambiente contemporâneo requer o envolvimento dos colaboradores na construção da estratégia.

Cabe ressaltar que Mintzberg (2003a) não nega o planejamento como um fator importante do processo estratégico, mas incorpora a este o componente emergente da estratégia que, em última instância, tira parte do controle da organização das mãos do estrategista. Devido a isso, a estratégia vista como um padrão, claramente afeta idealização de controle sustentada pelas escolas de pensamento tradicionais. Isso contribuiu para desencadear um acirrado debate semântico e teórico em torno dos pontos de vista acerca da concepção de estratégia emergente.

Por um lado autores como Hamel (1996) se aproveitaram do conceito de estratégias emergentes e da evolução das empresas japonesas nas décadas de 1980 e 1990, para diminuir a importância do planejamento estratégico e do controle e transferir para o aprendizado organizacional a responsabilidade pela habilidade criativa e reativa das organizações. Nas palavras de Hamel (1996), o "planejamento diz respeito a programar, não sobre descobrir. Planejamento é para tecnocratas, não para sonhadores. Dar aos planejadores a responsabilidade pela estratégia é como pedir a um pedreiro para criar uma Pietà de Michelangelo." ${ }^{36}$ (HAMEL, 1996, p. 71, tradução nossa) Na concepção do autor as estratégias devem emergir a partir de novas pessoas que, como um novo código genético,

\footnotetext{
${ }^{35}$ Do inglês: "So-called strategic planning must be recognized for what it is: a means, not to create strategy, but to program a strategy already created - to work out its implications formally."

${ }^{36}$ Do inglês: "The essential problem in organizations today is a failure to distinguish planning from strategizing. Planning is about programming, not discovering. Planning is for technocrats, not dreamers. Giving planners responsibility for creating strategy is like asking a bricklayer to create a Michelangelo's Pietà."
} 
trazem novas ideias, novas conversas entre as partes e novos apegos por certas oportunidades.

Em um extremo oposto, autores como Porter $(1990,1996)$, defendem a concepção de controle das escolas tradicionais. Para o autor a aprendizagem é um mero mecanismo de redução de custos ou diferenciação. O autor claramente não reconhece os padrões operacionais como estratégia, tampouco reconhece o aprendizado organizacional como parte do processo estratégico das organizações.

Mintzberg (1987a, b, 2003c), obviamente, contesta tal perspectiva e também argumenta em favor da estratégia emergente, mas o faz através de uma postura, apesar de crítica, conciliadora entre os dois pontos de vista extremos. Em seu livro Strategy Safari, o autor, juntamente com Ahlstrand e Lampel, ressaltam que a prática mostra que a maioria das organizações teria como estratégia realizada um meio termo entre o pretendido e o emergente e deveria operar a partir de um balanço harmonioso entre capacidade de previsão e capacidade de adaptação da organização. Qualquer um dos extremos seria, então, prejudicial para as organizações, já que estratégias puramente deliberadas significariam aprendizado zero, enquanto estratégias puramente emergentes significariam controle zero - ver figura 9 (MINTZBERG; AHLSTRAND; LAMPEL, 1998).

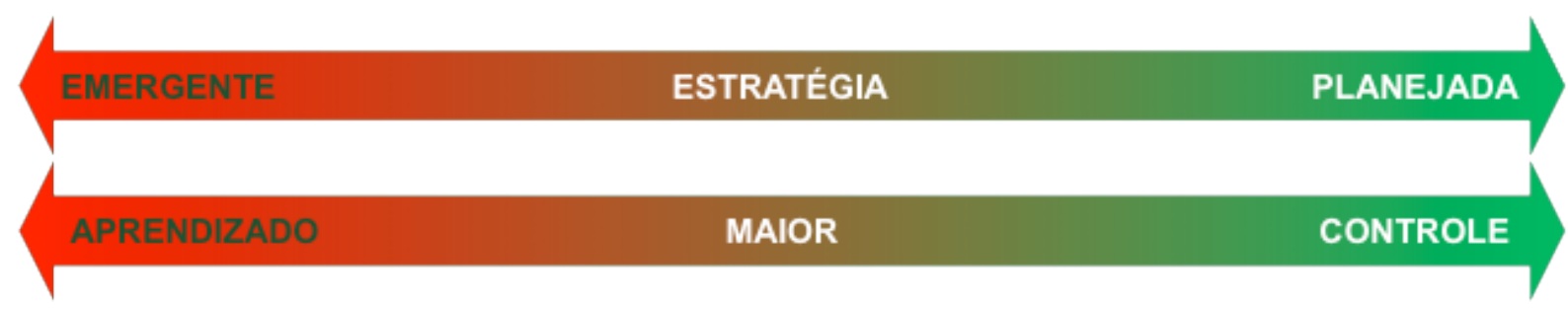

Figura 9 - Estratégia como padrão e as implicações de seus extremos polares. Fonte: Elaborada pelo autor.

Apesar do evidente caráter conciliador das abordagens de Henry Mintzberg, ele e Michael Porter travaram um acirrado debate acerca destas concepções de estratégia, por meio de seus livros e artigos. Os pontos altos deste debate ocorreram com a publicação do artigo What is strategy? De Michael Porter em 1996 e com a publicação do livro Strategy safari de Henry Mintzberg, Bruce Ahlstrand e Joseph Lampel, publicado em 1998.

Porter (1996) defende que a estratégia consiste na escolha deliberada de uma posição única e defensável por parte das organizações e para isso fez um ataque direcionado aos entusiastas da estratégia emergente. Neste artigo o autor sustenta a ideia que a 
estratégia é um componente essencial para o sucesso das organizações e, por isso, o aprendizado não deve emergir e sim ser fruto de um conjunto de metas cuidadosamente planejadas e deliberadas pelo estrategista, para possibilitar a redução de custos operacionais. Neste sentido, o autor argumenta que o aprendizado não pode ser estratégia, uma vez que é fruto da mesma. A dicotomia criada por Porter $(1990,1996,1999)$ entre a eficácia operacional e a estratégia como uma posição única, deliberada por meio de um plano, levou Porter (1996, p. 63, tradução nossa) à conclusão paradoxal de que "as corporações japonesas raramente possuem estratégias" ${ }^{37}$, já que normalmente estas copiam umas às outras.

Mintzberg, Ahlstrand e Lampel (1998) se aproveitaram desta constatação para dar um desfecho em seu favor para este embate. Os autores, destacaram que se a estratégia era algo essencial para a obtenção do sucesso, como afirmava Porter (1996), então as bem sucedidas empresas japonesas precisariam ter alguma forma de estratégia, já que claramente vinham tendo sucesso. Com base nesta observação, os autores declararam que o controle estratégico precisa “[...] alargar seu escopo para além do planejamento estratégico. Estratégias não precisam ser deliberadas para serem efetivas." ${ }^{38}$ (MINTZBERG; AHLSTRAND; LAMPEL, 1998, p. 54, tradução nossa)

Além do eixo entre planejamento e emergência estratégica - que, em última instância, se baseia na concepção de estratégia como padrão -, a estratégia orbita em torno de um segundo eixo, cujos antagônicos são o foco no ambiente externo e o foco no ambiente interno da organização. Um dos extremos deste eixo é dado pela concepção de estratégia como posição, já introduzida anteriormente. Esta concepção foi proposta no revolucionário livro Competitive Strategy de Michael Porter, publicado em 1980. Nesta obra o autor prescrevia um conjunto de instrumentos, baseados na concepção de estratégia como um plano maior para a organização, que traziam consigo algumas inovações importantes. Na concepção de Porter (1999) haveriam apenas três tipos de estratégias genéricas, as estratégias de liderança em custo, de diferenciação e de enfoque ou nicho. Para o autor a estratégia se consistiria em, deliberadamente, fortificar uma única posição dentre estas, através da construção de barreiras para protegê-la (PORTER, 1990, 1999).

\footnotetext{
${ }^{37}$ Do inglês: "Japanese companies rarely have strategies."

38 Do inglês: "[...] to broaden its scope beyond strategic planning. Strategies need not be deliberate to be effective."
} 
Markides (2002, p. 229) ressalta que o ideal de estratégia de Porter conduz a uma situação em que "estratégia envolve fazer escolhas difíceis em três dimensões: que clientes focalizar, que produtos oferecer e que atividades realizar." Sob esta a perspectiva a essência da estratégia está em fazer escolhas de posições com base em possibilidades de futuro acerca do mercado em que a empresa se encontra inserida. Em última instância, este ponto de vista conduz à necessidade do estrategista "[...] limitar o conjunto de circunstâncias que podem vir a ocorrer." (PORTER, 1996; 1999, p. 223; MARKIDES, 2002) Porter (1999) acredita, então, que por meio do planejamento e da escolha de uma posição sólida é possível dar conta das mudanças ambientais e reduzir os riscos das incertezas dos cenários aos quais as organizações se encontram submetidas.

Mintzberg, Ahlstrand e Lampel (1998) ressaltam que a concepção da estratégia como a escolha de uma posição teve impacto significativo no ambiente de negócios e acabou por se tornar a abordagem dominante até os dias de hoje. Porém, em um extremo antagônico à esta concepção, encontra-se um ponto de vista que enxerga a estratégia como uma perspectiva da própria organização. Esta percepção tem como defensores importantes Peter Ferdinand Drucker e Peter M. Senge. Diferentemente das concepções daqueles que observam a estratégia como a busca por uma posição, a ideia central desta concepção é a de que "qualquer tentativa para se basear ações e compromissos de hoje em previsões de eventos futuros é inútil." (DRUCKER, 1998, p. 151)

Neste ponto de vista a estratégia estaria ligada à maneira com a qual a organização desenvolve suas atividades e à forma com a qual seus executivos abordam os problemas. Deste modo, a estratégia como perspectiva se fundamenta em concepções próximas às da estratégia emergente. Nesta abordagem as estratégias, sejam elas deliberadas ou emergentes, devem se basear, essencialmente, no aprendizado e no comprometimento dos colaboradores (MINTZBERG, 1987b; DRUCKER, 1998; MINTZBERG; AHLSTRAND; LAMPEL, 1998; DRUCKER, 1999; SENGE, 2009).

Pode-se dizer, então, que enquanto a estratégia como posição significa se direcionar a mercados específicos, a estratégia como perspectiva significa fazer as coisas de maneiras específicas - ver figura 10. 


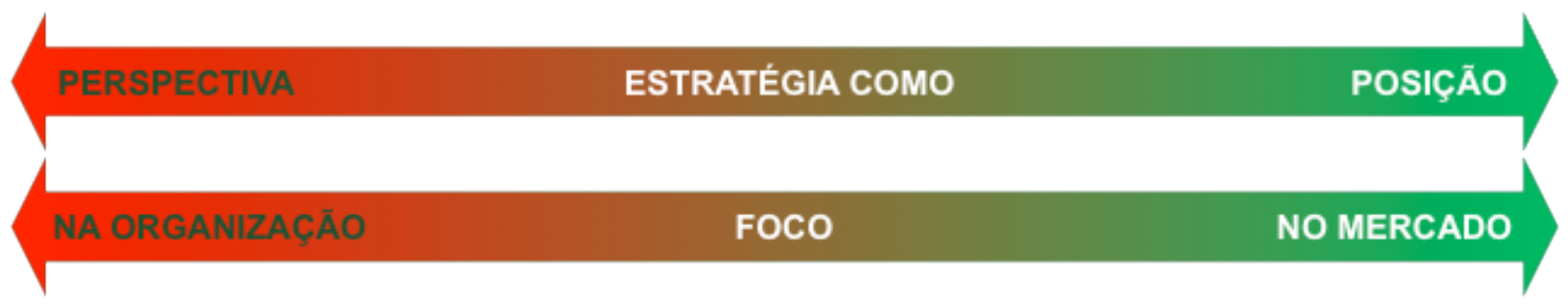

Figura 10 - Foco da estratégia como posição ou como perspectiva.

Fonte: Elaborada pelo autor.

Por fim, Mintzberg (1987b), aponta para uma última definição de estratégia, onde esta seria tratada como um estratagema, ou um truque. Esta concepção deriva da ideia de estratégia como um plano, contudo trata-se de um plano com particularidades, onde não se busca estabelecer um futuro pretendido e sim estabelecer formas para ludibriar os concorrentes. Esta concepção é uma das que remete mais claramente às antigas abordagens militares, como as de Tzu (1983), de tal forma que os concorrentes são concebidos como adversários a serem batidos.

\section{A fera da estratégia: áreas de concordância \\ (Adaptado de Chaffee, 1985: 89-90)}

- A estratégia trata tanto da organização como do ambiente. "Uma premissa básica do pensamento estratégico diz respeito à impossibilidade de separar organização e ambiente... A organização usa a estratégia para lidar com as mudanças nos ambientes."

- A essência da estratégia é complexa. "Como as mudanças trazem novas combinações de circunstâncias para a organização, a essência da estratégia permanece não-estruturada, nãoprogramada, não rotineira e não repetitiva..."

- A estratégia afeta o bem-estar geral da organização. “... decisões estratégicas... são consideradas importantes o suficiente para afetar o bem-estar geral da organização..."

- A estratégia envolve questões tanto de conteúdo como de processo. "O estudo da estratégia inclui as ações decididas, ou o conceito de estratégia, e também processos pelos quais as ações são decididas e implementadas."

- As estratégias não são puramente deliberadas. "Os teóricos... concordam que as estratégias pretendidas, emergentes e realizadas podem diferir entre si".

- As estratégias existem em níveis diferentes. “... as empresas têm... estratégia corporativa ("em que negócio deveremos estar) e estratégia de negócios ("como iremos competir em cada negócio?)"

- A estratégia envolve vários processos de pensamento. “... a estratégia envolve exercícios conceituais, assim como analíticos. Alguns autores enfatizam a dimensão analítica mais que as outras, mas a maioria afirma que o coração da formulação estratégica é o trabalho conceitual feito pelos líderes da organização".

Quadro 3 - Áreas de concordâncias acerca da estratégia. Fonte: Mintzberg Ahlstrand e Lampel (1998, p. 16, tradução nossa) 
Em um esforço para organizar os pontos em comum, abordados por estas cinco perspectivas acerca da estratégia, Mintzberg, Ahlstrand e Lampel (1998) adaptaram dos trabalhos de Chaffee (1985) uma compilação dos pontos de concordâncias a respeito da "fera da estratégia", que podem ser vistos no quadro 3. É importante ressaltar que estas áreas de concordância não oferecem uma definição sintética do termo estratégia, tampouco do problema estratégico. Porém, elas se constituem em uma contribuição importante para que se possa perceber os aspectos que devem estar contemplados em uma definição do tipo, já que fazem parte das feições capturadas pelos múltiplos pontos de vista obtidos nos estudos do problema no decorrer do tempo.

Quando abordada por meio destes múltiplos pontos de vista, a:

[...] estratégia não é apenas uma ideia sobre como lidar com um adversário, ou um conjunto de concorrentes em um mercado, como é tratado em muito da literatura ou de seu uso popular. Ela também destaca algumas questões fundamentais sobre as organizações como instrumentos de percepção e ação coletiva. ${ }^{39}$ (MINTZBERG, 2003b, p. 21, tradução nossa)

Os estudos de Minzberg (1987b) mostraram que a concepção de estratégia estaria, invariavelmente, concentrada sobre dois eixos principais, o da governança, baseado na dicotomia entre aprendizado e controle - ver figura 9 - e o do foco, cuja dicotomia envolve os aspectos internos e externos à organização - ver figura 10. Neste contexto o problema da estratégica estaria intimamente ligado à governança em sistemas complexos, ricamente interligados e perturbados por aspectos internos e externos. Estes eixos comuns exigem uma concepção onde a estratégia seja vista não como um ato puramente deliberado, mas como "um processo organizacional, de diversas formas inseparável da estrutura, do comportamento e cultura da empresa em que ocorre." ${ }^{40}$ (ANDREWS, 2003, p. 73, tradução nossa)

\footnotetext{
${ }^{39}$ Do inglês: "[...] strategy is not just a notion of how to deal with an enemy or a set of competitors or a market, as it is treated in so much of the literature and its popular usage. It also draws us into some of the most fundamental issues about organizations as instruments for collective perception and action."

${ }^{40}$ Do inglês: "Corporate strategy is an organization process, in many ways inseparable from the structure, behavior, and culture of the company in which takes place."
} 


\subsection{MINTZBERG, AHLSTRAND E LAMPEL E O PROCESSO ESTRATÉGICO}

Diante das múltiplas perspectivas acerca da estratégia Mintzberg, Ahlstrand e Lampel (1998) procuraram estudar as diversas facetas exploradas nas pesquisas a respeito do tema. Como mostrado no capítulo anterior, os autores entendem que a estratégia não pode ser percebida apenas como um plano administrável, ela exige uma ampliação das estruturas teóricas, que the permita ser tratada e entendida como um grande processo. Com base nesta concepção, os autores produziram um profundo levantamento sobre pontos de vista acerca da estratégia, que englobou tanto o eixo que envolve os aspectos internos e externos, como aquele que envolve a governança. Este esforço produziu uma síntese de dez escolas de pensamento, que foram agrupadas em um único "processo estratégico".

\begin{tabular}{|c|c|c|c|c|c|}
\hline & Escola & $\begin{array}{l}\text { Disciplinas base ou } \\
\text { relacionadas }\end{array}$ & $\begin{array}{c}\text { Mensagem } \\
\text { intrínseca }\end{array}$ & $\begin{array}{c}\text { Extremo } \\
\text { ilógico }\end{array}$ & $\begin{array}{l}\text { Principais } \\
\text { representantes }\end{array}$ \\
\hline \multirow{3}{*}{ 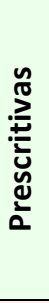 } & Design & Arquitetura (Metáfora) & Adequar & Fixação & $\begin{array}{c}\text { P. Selznick e K.R. } \\
\text { Andrews }\end{array}$ \\
\hline & Planejamento & $\begin{array}{c}\text { Planejamento urbano, } \\
\text { teoria dos sistemas e } \\
\text { cibernética }\end{array}$ & Formalizar & Ritualização & H. Igor Ansoff \\
\hline & Posicionamento & $\begin{array}{c}\text { Economia e história } \\
\text { militar }\end{array}$ & Analisar & Fortificação & $\begin{array}{c}\text { D. E. Schendel, K. J. } \\
\text { Hatten e Michael Porter }\end{array}$ \\
\hline \multirow{7}{*}{ 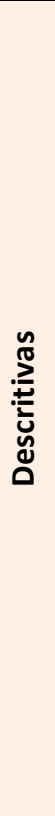 } & Empreendedora & Economia & Pressentir & idolatria & $\begin{array}{c}\text { J.A. Schumpeter e A.H. } \\
\text { Cole }\end{array}$ \\
\hline & Cognitiva & Psicologia & $\begin{array}{l}\text { Lidar ou } \\
\text { criar }\end{array}$ & Fantasia & $\begin{array}{l}\text { H.A. Simon e J. G. } \\
\text { March }\end{array}$ \\
\hline & Aprendizado & $\begin{array}{l}\text { Caos e psicologia } \\
\text { (aprendizado) }\end{array}$ & Aprender & Impulso & $\begin{array}{l}\text { C.E. Lindblom, R. M. } \\
\text { Cyert, J. G. March, K. E. } \\
\text { Weick, J.B. Quinn, C. K. } \\
\text { Prahalad, G. Hamel e P. } \\
\text { Senge }\end{array}$ \\
\hline & Poder & Ciência política & Agarrar & Intriga & $\begin{array}{l}\text { G. T. Allison, J. Pfeffer, } \\
\text { G. R. Salancik e W. G. } \\
\text { Astley }\end{array}$ \\
\hline & Cultural & Antropologia & Aglutinar & Excentricidade & $\begin{array}{c}\text { E. Rhenman, e R. } \\
\text { Normann }\end{array}$ \\
\hline & Ambiental & Biologia & Reagir & Submissão & $\begin{array}{l}\text { M. T. Hannan e J. } \\
\text { Freeman }\end{array}$ \\
\hline & Configuração & História & $\begin{array}{l}\text { Integrar, } \\
\text { transformar }\end{array}$ & Degeneração & $\begin{array}{l}\text { A. D. Chandler, H. } \\
\text { Mintzberg, D. Miller, R. } \\
\text { E. Miles e C. C. Snow }\end{array}$ \\
\hline
\end{tabular}


Três destas linhas de pensamento foram denominadas por Mintzberg, Ahlstrand e Lampel (1998) de "Escolas prescritivas". Em síntese, estas escolas partem da premissa que a estratégica pode ser deliberada, administrada e controlada a partir de um conjunto de boas práticas. As demais escolas foram denominadas pelos autores de "Escolas Descritivas". Estas se abstém de prescrever métodos para elaboração e controle das estratégias e se concentram em descrever os componentes do processo estratégico e suas implicações. Os principais representantes, disciplinas e mensagens de cada uma destas escolas podem ser encontrados no quadro 4.

\subsubsection{Escolas prescritivas}

\section{Escola do Design:}

A escola do Design teve um grande impulso a partir de 1965, quando os aspectos externos foram reconhecidos como importantes para as organizações. Suas concepções acerca da estratégia foram dominantes até a década de 1970 e, por seu pioneirismo, ela teve grande influência sobre as demais escolas prescritivas (MINTZBERG; AHLSTRAND; LAMPEL, 1998; MINTZBERG; LAMPEL, 1999).

Esta linha de pensamento "[...] vê a formação da estratégia como um meio de atingir o ajuste fundamental entre os pontos fortes e fracos internos, e as ameaças e oportunidades externas." ${ }^{41}$ (MINTZBERG; LAMPEL, 1999, p. 22, tradução nossa) Sob esta perspectiva não há preocupação com o conteúdo da estratégia. A produção de estratégias é um ato criativo do executivo principal, que deriva da capacidade do mesmo de prever o estado do cenário externo, a partir de um conjunto de estudos ambientais. Portanto, os defensores desta escola pressupõe que o ambiente pode ser entendido, tanto no presente como no futuro (MINTZBERG; AHLSTRAND; LAMPEL, 1998).

Este ponto de vista segue um preceito no qual a estrutura deve se adequar à estratégia o que cria uma clara distinção entre a formulação e a implementação da estratégia. Nele, a formulação precede, obrigatoriamente, a implementação e esta

\footnotetext{
${ }^{41}$ Do inglês: "[...] see strategy formation as achieving the essential fit between internal strengths and weakness
} and external threats and opportunities." 
dicotomia leva a uma condição na qual a estratégia deve ser implementada de acordo com o que foi concebida. Portanto, nesta linha de pensamento não há espaço para emergência estratégica ou para alterações das estratégias durante a implementação (MINTZBERG; AHLSTRAND; LAMPEL, 1998).

Desse modo, a escola do Design segue uma linha estreita entre a intuição inconsciente do estrategista e a análise formal do ambiente, que a distingue das demais escolas prescritivas. Ao adotar tal postura, esta perspectiva considera que estratégia deliberada pode apagar o aprendizado prévio da organização e as determinações do ambiente. Com isso ela se permite negar o incrementalismo, o que pode restringir a capacidade de ação da organização em condições de incerteza. (MINTZBERG; AHLSTRAND; LAMPEL, 1998).

\section{Escola do Planejamento:}

A escola do Planejamento originou-se praticamente junto com a escola do Design e predominou entre as décadas de 1970 e 1980. Seu tratado mais influente é o livro Corporate Strategy de 1965, escrito por Igor Ansoff (MINTZBERG; AHLSTRAND; LAMPEL, 1998; MINTZBERG; LAMPEL, 1999). Esta escola se abstém de avaliar como ocorre o processo de criação da estratégia e se concentra em formalizar o processo que organiza a criação da estratégia (MINTZBERG; AHLSTRAND; LAMPEL, 1998).

De acordo com autores desta linha de pensamento, como Ansoff, Declerck e Hayes (1981) a estratégia é tida como um plano que abrange a:

[...] análise racional das oportunidades oferecidas pelo meio, dos pontos fortes e fracos das empresas e da escolha de um modo de compatibilização (estratégia) entre os dois extremos, compatibilização esta que deveria satisfazer do melhor modo possível aos objetivos da empresa. (ANSOFF; HAYES, 1981, p. 15)

A escola do Planejamento aproveita-se dos modelos básicos da escola do Design e, assim como ela, esta concepção também depende de previsões de cenários que sejam, ao mesmo tempo, amplas para abranger o máximo de contingências e estreitas para serem gerenciáveis (MINTZBERG; AHLSTRAND; LAMPEL, 1998). Contudo, ela difere desta última no aspecto de que nela "[...] o processo não é apenas cerebral, mas formal, passível de decomposição em etapas distintas, delineadas por listas de verificação e apoiadas pelas 
técnicas." ${ }^{42}$ (MINTZBERG; LAMPEL, 1999, p. 22, tradução nossa) Em outras palavras, para os defensores desta escola, a estratégia é, “[...] no limite, praticamente mecanicamente programada"43 $^{43}$ (MINTZBERG; AHLSTRAND; LAMPEL, 1998, p. 57, tradução nossa) Por isso, ela exige que haja certo nível de estabilidade e capacidade preditiva acerca do curso do ambiente (MINTZBERG; AHLSTRAND; LAMPEL, 1998).

O processo analítico de planejamento e programação das estratégias tira muita da importância dos gerentes intermediários e até mesmo os altos executivos, já que diante desta concepção o processo de formulação é determinado por uma metodologia bem definida. Isso conduz a um desligamento entre quem planeja e os detalhes inerentes a implementação. Deste modo, esta concepção depende do pressuposto de que os dados, tanto internos como externos, chegarão precisos e empacotados para possibilitar tanto o planejamento como a execução apropriados (MINTZBERG; AHLSTRAND; LAMPEL, 1998).

Devido a estas características, Kaplan e Norton (1997, p. 17) afirmam que "a estratégia planejada, embora iniciada com as melhores intenções e com os melhores conhecimentos e informações disponíveis, talvez tenha deixado de ser adequada ou válida dentro das circunstâncias atuais." Neste sentido, Hamel (1996) e Mintzberg, Ahlstrand e Lampel (1998) afirmam que a capacidade transformadora e adaptativa das organizações depende de processos baseados em indivíduos criativos, que acabam por ser limitados pelas metodologias impostas pelo planejamento.

Mesmo Ansoff e Hayes (1981) admitem que o pensamento fortemente analítico e cartesiano desta abordagem implica em limitações, já que o planejamento, por si só, não é provocador de ações e mudanças na organização. Para os autores, a obtenção de maior desempenho organizacional passa, também, por outras aptidões organizacionais como informação estratégica, sistemas, estruturas fluídas e administradores bem treinados. Com isso, pode-se dizer que mesmo os autores que estabeleceram as premissas do planejamento estratégico, identificaram as limitações nas concepções iniciais acerca da estratégia planejada e acabaram por antecipar certas premissas dos defensores das estratégias emergentes.

\footnotetext{
42 Do inglês: "[...] the process is not just cerebral but formal, decomposable into distinct steps, delineated by checklists, and supported by techniques (especially with regard to objectives, budgets, programs, and operating plans).

${ }^{43}$ Do inglês: "[...] at the limit almost mechanicaly programmed."
} 
Mesmo diante de suas limitações para lidar com o problema da mudança, esta escola de pensamento teve grande importância para os estudos acerca da estratégia, já que foi um dos primeiros processos propostos para resolver o problema estratégico (ANSOFF; HAYES, 1981). Mesmo diante de circunstâncias turbulentas, os métodos desta escola podem auxiliar a análise que precede a "caixa preta" da formulação da estratégia, assim como a catalisação e programação da mesma (MINTZBERG; AHLSTRAND; LAMPEL, 1998). Além disso, Mintzberg, Ahlstrand e Lampel (1998) e Burgelman e Grove (2007) ressaltam que planejamento se constitui em uma ferramenta comprovadamente eficaz para lidar com a coordenação de atividades em ambientes estáveis e, por isso, não pode ser negligenciado.

\section{Escola do Posicionamento:}

A escola do Posicionamento ganhou força no começo da década de 1980, por meio dos esforços de Michael Porter, e trata-se da linha de pensamento dominante no meio de gestão. (PRAHALAD; HAMEL, 1994; MINTZBERG; AHLSTRAND; LAMPEL, 1998). Ela se baseia em muitas das concepções das escolas do Design e do Planejamento, mas foi além do processo de formulação, no qual se baseavam estas escolas, e se aprofundou no processo de criação das estratégias. A ideia central por trás desta concepção é a instrumentalização da estratégia. Para tal, ela parte do pressuposto que tanto as estratégias, como as condições ambientais são generalizáveis (MINTZBERG; AHLSTRAND; LAMPEL, 1998).

Neste pondo de vista o estrategista é capaz de selecionar uma estratégia adequada para lidar com o ambiente externo, a partir de um conjunto de estratégias genéricas - a saber, liderança em custo, diferenciação e enfoque em determinado nicho (PORTER, 1999). Isso permite que a estratégia seja tratada como um processo controlado e consciente, onde a estrutura da indústria precede a estratégia que, por sua vez, precede a estrutura da organização (MINTZBERG; AHLSTRAND; LAMPEL, 1998). Pode-se dizer, então, que sob esta concepção o foco da estratégia se dá com maior ênfase no cenário externo, já que o cenário interno é um mero reflexo do mesmo.

A escola do posicionamento valoriza o papel dos analistas para as organizações, pois a instrumentalização, por ela propiciada, transforma o processo de formulação estratégica em um método de seleção analítica de estratégias genéricas, o que rompe com a ideia de concepção criativa, proposta pela escola do Design (MINTZBERG; AHLSTRAND; LAMPEL, 1998). Neste sentido, pode-se dizer que a escola do Posicionamento “[...] de fato está entre 
as mais deterministas entre todas as escolas de pensamento sobre formação de estratégias." $^{\text {"44 }}$ (MINTZBERG; AHLSTRAND; LAMPEL, 1998, p. 118, tradução nossa)

Esta escola também considera os mercados como essencialmente estáveis e duradouros, o que distancia o analista do mundo tangível. Nestas condições, a ação dos analistas pode ficar impossibilitada diante de uma possível fragmentação da indústria (PRAHALAD; HAMEL, 1994; MINTZBERG; AHLSTRAND; LAMPEL, 1998). Tal situação pode assumir condições ainda mais graves para as organizações, já que uma abordagem essencialmente analítica "[...] pode tornar o processo de criação de estratégias excessivamente deliberado e, assim, prejudicar o aprendizado estratégico." ${ }^{45}$ (MINTZBERG; AHLSTRAND; LAMPEL, 1998, p. 112, tradução nossa)

Um aspecto relevante da escola do Posicionamento é que Porter (1999) e seus seguidores, estruturaram uma parcela importante de sua argumentação e de suas metodologias em analogias entre a competição na indústria e um campo de batalha. Em decorrência disso, esta escola importou muitas das características das escolas militares clássicas. A própria concepção de estratégias genéricas apresenta um paralelo militar que pode encontrado em obras como as do general chinês Sun Tzu (TZU, 1983; MINTZBERG; AHLSTRAND; LAMPEL, 1998; MINTZBERG; LAMPEL, 1999).

Com base nestas premissas o autor prescreveu um conjunto de movimentos ofensivos e defensivos, baseados em forças competitivas, que poderiam afetar os concorrentes de diferentes maneiras e desencadear batalhas em determinados mercados. $\mathrm{O}$ preocupante desvio, em direção à competição, pode ser visto na obra pioneira de Porter (1999). Nela o autor argumenta que o enfoque competitivo se justifica, pois a cooperação nos mercados se defronta com uma condição análoga ao dilema do prisioneiro da teoria dos jogos, onde a busca por uma condição na qual a indústria como um todo ganhe, pode significar o sacrifício de lucros e parcelas de mercado. Para Porter (1999), tal condição exige que as empresas mantenham um enfoque no desempenho individual, onde a ideia de compromisso seria apenas uma forma de comunicar as intenções da empresa.

Para Ghoshal, Bertlett e Moran (2002) as abordagens de Porter - relacionadas à competição - levam as empresas a posições conflitantes com as da sociedade. Enquanto a

\footnotetext{
${ }^{44}$ Do inglês: "[...] is in fact among the most deterministic of all the schools of thought on strategy formation."

45 Do inglês: "[...] can render the strategy-making process excessively deliberate and so undermine strategylearning."
} 
maior competição é favorável para esta última, na concepção de Porter o propósito estratégico consiste em restringir esta competição. Destarte, para teoria estratégica de Porter "a destruição do bem estar social não é apenas um subproduto ocasional da estratégia; é o objetivo fundamental das empresas que buscam lucro [...]". (GHOSHAL; BERTLETT; MORAN, 2002, p. 22)

Mintzberg Ahlstrand e Lampel (1998, p. 112, tradução nossa) concordam com tal ponto de vista e afirmam que o problema desta escola de pensamento não é que ela esteja errada e sim que ela possui um foco estreito que a orienta para "[...] o econômico e, em especial, o quantificável [...]"46, deixando os aspectos humanos e sociais, assim como a perspectiva única, de lado. Portanto, este enfoque de origem militar, apresenta implicações significativas para os aspectos sociais das organizações, uma vez que a competitividade assume um papel crucial, sobrepujando a cooperação e outras formas de relacionamento entre as organizações e o ambiente que as cercam.

Mas há de se ressaltar que, apesar de suas limitações, esta linha de pensamento trouxe contribuições importantes, como o desenvolvimento daquela que seria uma das primeiras caracterizações dos componentes que constituem o problema estratégico. Grande parte deste esforço se deve à obra de Porter (1999), que descreveu os principais componentes dos aspectos internos e externos à organização.

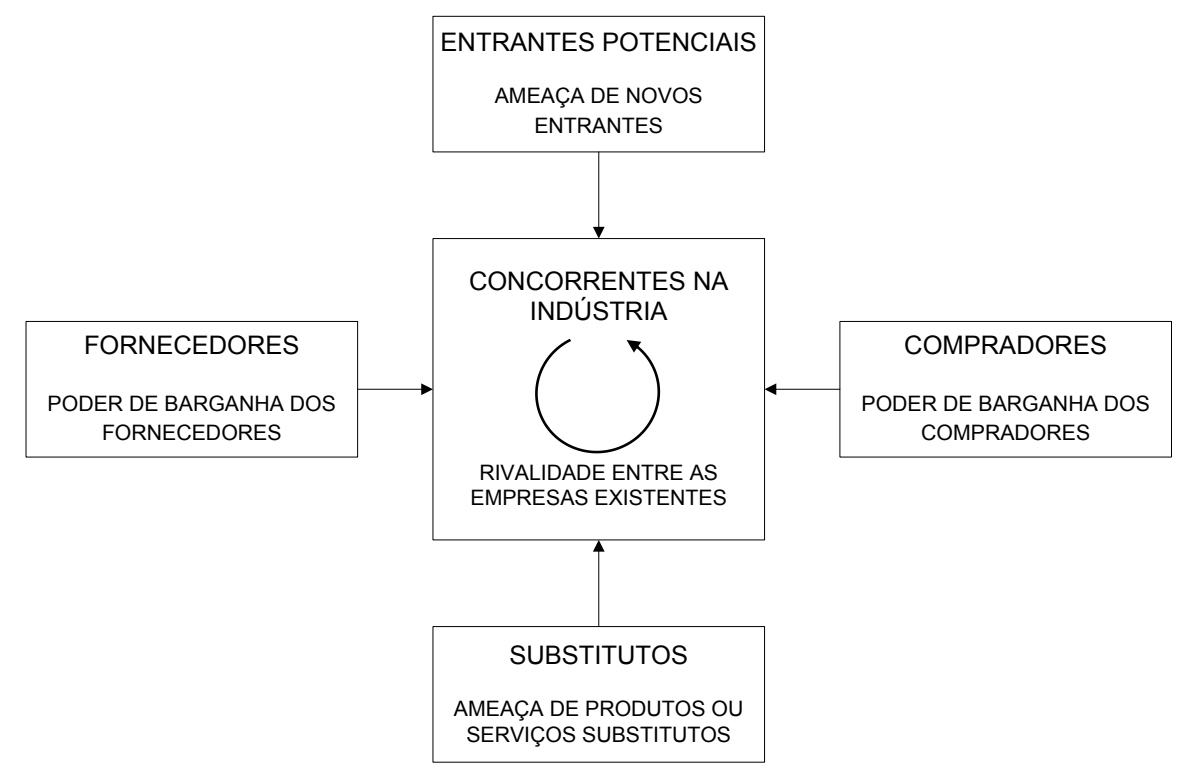

Figura 11 - Modelo de cinco forças de Porter.

Adaptado de: Porter (1990, p. 4; 1999, p. 23)

\footnotetext{
${ }^{46}$ Do inglês: "[...] the economic and especially the quantifiable [...]."
} 
Na esfera do cenário externo Porter (1999) construiu um modelo que ilustra os componentes do problema estratégico com foco na rivalidade da indústria. Este modelo ficou conhecido como modelo de cinco forças Porter. Nele a rivalidade da indústria é descrita por meio de dois eixos principais, em um destes eixos estão contempladas as pressões provocadas pela possibilidade de entrantes em potencial e pela pressão dos produtos substitutos e no outro eixo encontram-se contemplados o poder de barganha dos fornecedores e o poder de barganha dos compradores da indústria em questão - ver figura 11.

Já o cenário interno foi descrito pelo autor de forma independente do cenário externo, tendo por base a concepção cartesiana de que "a vantagem competitiva não pode ser compreendida observando-se a empresa como um todo. Ela tem sua origem nas inúmeras atividades distintas que uma empresa executa no projeto, na produção, no marketing, na entrega e no suporte de seu produto." (PORTER, 1990, p. 31) A partir deste ponto de vista, Porter descreveu os aspectos internos da organização em termos de suas unidades de execução, naquilo que denominou de cadeia de valor genérica - ver figura 12.

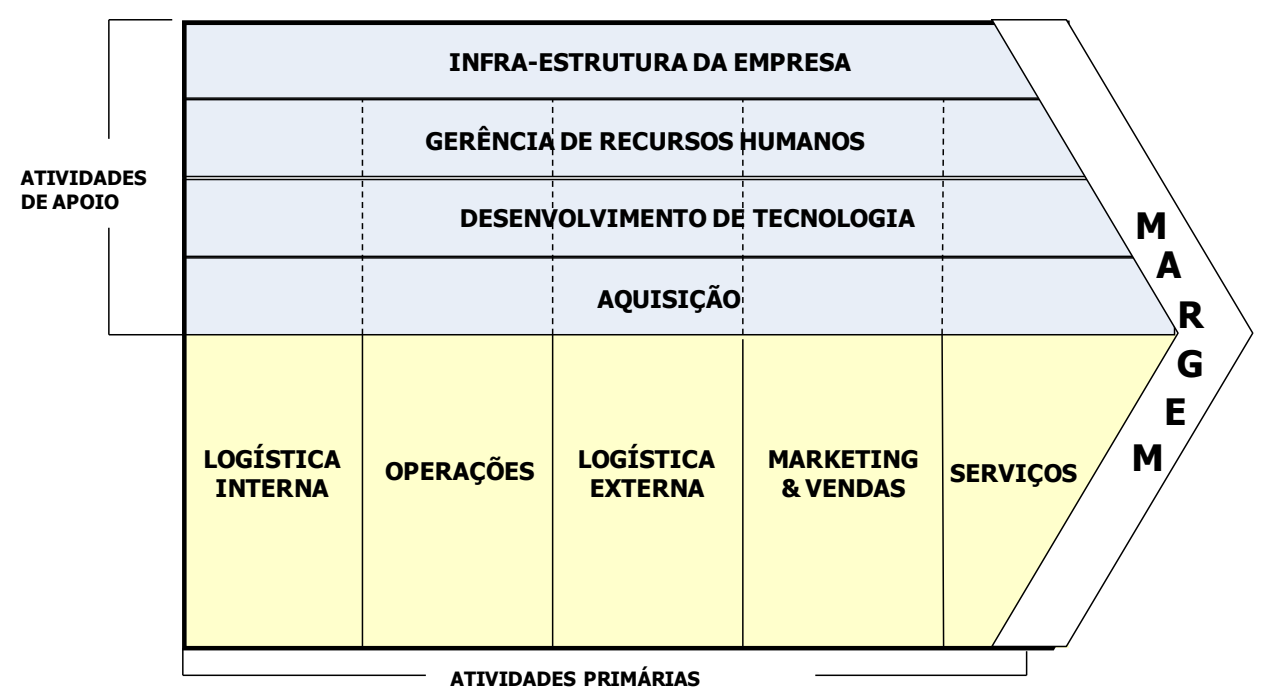

Figura 12 - Cadeia de Valor genérica

Fonte: Porter (1990, p. 34)

Mesmo com as descrições de Porter (1990) se tratando de concepções tipicamente reducionistas, focadas nos componentes do problema, o próprio autor percebeu que as inter-relações entre as unidades de negócios, o mercado e os concorrentes, assim como os elos que unem cada um dos fragmentos mostrados na cadeia de valor, se apresentavam 
como um elemento que pode promover benefícios às organizações. Porém, devido ao enfoque tipicamente cartesiano, os trabalhos do autor não deram conta das inter-relações informais e indiretas e, por isso, suas descrições, apesar de úteis pelo pioneirismo, se mostram insuficientes para descrever os aspectos dinâmicos, tão importantes para a compreensão da complexidade do problema estratégico.

\subsubsection{Escolas descritivas}

\section{Escola empreendedora}

Esta linha de pensamento nasceu com base nas ciências econômicas (MINTZBERG; AHLSTRAND; LAMPEL, 1998). “[...] Em oposição à escola do planejamento, seu processo [tem] raízes nos mistérios da intuição." ${ }^{47}$ (MINTZBERG; LAMPEL, 1999, p. 22, tradução nossa) Ela baseia o processo estratégico em uma visão individual que enfatiza as habilidades inatas do líder, como a intuição, o julgamento e a sabedoria. Isso promove uma visão da estratégia como uma perspectiva para a organização, que ao mesmo tempo é deliberada e emergente, ao passo que dão senso de direção à empresa, ao mesmo tempo que aceitam adaptações no decorrer do tempo.

Apesar de operar sob a ideia de uma perspectiva de longo prazo, nesta escola as ações são tratadas como revolucionárias, ou seja, de curta duração (apesar dos efeitos não o serem), diferente das escolas clássicas, onde as ações são de longa duração, dentro de uma perspectiva evolucionária (MINTZBERG; AHLSTRAND; LAMPEL, 1998). Nesta escola a estratégia se move em grandes saltos, com o objetivo de aproveitar oportunidades que nem sempre poderiam ser aproveitadas quando as informações necessárias estão disponíveis para uma tomada de decisão analítica (MINTZBERG; AHLSTRAND; LAMPEL, 1998).

Em comum acordo com a escola do Design, esta linha de pensamento identifica o centro do processo estratégico no executivo principal da organização. Contudo, nela as estratégias não são vistas como planos e sim como perspectivas amplas, oriundas de habilidades inatas de um líder criativo, capaz de controlar a implementação de suas visões.

\footnotetext{
${ }^{47}$ Do inglês: "[...] opposite from the planning school, it rooted that process in the mysteries of intuition."
} 
(MINTZBERG; AHLSTRAND; LAMPEL, 1998; MINTZBERG; LAMPEL, 1999). Para os adeptos desta visão, os componentes chave para a liderança estratégica são o amplo conhecimento sobre o assunto, a habilidade do líder em fazer com que os outros vejam as coisas de maneira diferente, assim como ele, e um sentimento genuíno a respeito do que o líder diz. Em síntese, nesta linha de pensamento, a “[...] liderança visionária é o estilo e a estratégia juntos." ${ }^{48}$ (MINTZBERG; AHLSTRAND; LAMPEL, 1998, p. 139, tradução nossa)

\section{Escola Cognitiva}

A escola Cognitiva ganhou destaque na década de 1980 e ainda se encontra em fase de amadurecimento, com uma ampla diversidade de visões que ainda permanecem pouco integradas (MINTZBERG; AHLSTRAND; LAMPEL, 1998; MINTZBERG; LAMPEL, 1999).

Os autores desta linha de pensamento entendem que o mundo é demasiadamente complexo para ser compreendido por nossa mente limitada. Neste cenário, "a tomada de decisão se torna menos racional e mais um esforço em vão para ser racional." ${ }^{49}$ (MINTZBERG; AHLSTRAND; LAMPEL, 1998, p. 151, tradução nossa) Para lidar com esta complexidade a escola cognitiva entende que o gerente necessita de um amplo repertório de molduras, que lhe permitam ver o mundo por vários ângulos. Neste contexto, ela vê na intuição, ou na inspiração, a chave para a síntese dos conhecimentos que o estrategista possui, mas não sabe como acessar diretamente (MINTZBERG; AHLSTRAND; LAMPEL, 1998).

Os estudos desta escola também apontam para um cenário onde os estrategistas se mostram como autodidatas. Eles se baseiam em suas experiências para realizar suas ações e estas, por sua vez, são usadas para modelar seu conhecimento e assim sucessivamente. Nesta concepção a estratégia é fruto de uma interpretação do mundo, derivada da concepção de realidade adotada pela linha de pensamento de seus criadores. Com base nesta premissa, este ponto de vista enfatiza a tarefa do gestor e defende a necessidade de que o estrategista se utilize de estruturas mentais para organizar o conhecimento, tornando o gerente um processador de informações (MINTZBERG; AHLSTRAND; LAMPEL, 1998).

Desse modo, enquanto as outras linhas de pensamento se preocupam com os requisitos necessários para se pensar e realizar a estratégia, esta escola procura entender os processos mentais que compõem a formulação estratégica, tanto no âmbito analítico

\footnotetext{
${ }^{48}$ Do inglês: "[...] visionary leadership is style and strategy coupled together."

49 Do inglês: "Decision making thus becomes not so much rational as a vain effort to be rational."
} 
quando no âmbito subjetivo do processo (MINTZBERG; LAMPEL, 1999). Em outras palavras, esta concepção se concentra em sondar o que se passa na mente do estrategista, pois ela entende que é destes processos que a estratégia emerge como uma perspectiva (MINTZBERG; AHLSTRAND; LAMPEL, 1998).

\section{Escola do Aprendizado}

A escola do Aprendizado deu seus primeiros passos no final da década de 1950, mas foi na década de 1980 que ela se tornou uma das protagonistas no cenário dos estudos acerca da estratégia (MINTZBERG; AHLSTRAND; LAMPEL, 1998). Esta perspectiva parte do pressuposto que a complexidade do ambiente impede o controle deliberado da estratégia. Em decorrência disso, autores desta linha de pensamento, como Hamel (1996), entendem que planejar não é estratégia. Na concepção de tais autores, a estratégia deve ser vista como um processo incremental e contínuo de aprendizado, onde a organização não é de todo obediente ao executivo principal.

“Nesta visão, as estratégias são emergentes, os estrategistas podem ser encontrados em toda a organização e as chamadas formulação e implementação se interligam." ${ }^{50}$ (MINTZBERG; LAMPEL, 1999, p. 25, tradução nossa) Com isso, esta escola entende que o sistema coletivo da organização possui uma mente própria, capaz de estabelecer padrões de comportamento organizacional. Em síntese, esta linha de pensamento entende que as:

\footnotetext{
estratégias inicialmente crescem como ervas daninhas em um jardim, lançando raízes em todas as espécies de lugares estranhos. Algumas proliferam e se tornam amplamente organizacionais, às vezes sem nem mesmo serem reconhecidas como tais ou serem gerenciadas de forma consciente. ${ }^{11}$ (MINTZBERG; AHLSTRAND; LAMPEL, 1998, p. 195, tradução nossa)
}

Assim, a escola do aprendizado defende as estratégias podem emergir tanto a partir de estrategistas individuais, que impelem a organização em direção a um determinado padrão comportamental, como por meio da emergência de padrões de conduta coletivos. Portanto, esta escola entende que o papel do executivo não é mais o de conceber e deliberar estratégias e sim o de gerenciar o aprendizado, com o objetivo de estabelecer um

\footnotetext{
${ }^{50}$ Do inglês: "In this view, strategies are emergent, strategists can be found through-out the organization, and so-called formulation and implementation intertwine."

51 Do inglês: "strategies grow initially like weeds in a garden, taking root in all kinds of strange places. Some proliferate, to become broadly organizational, sometimes without even being recognized as such, let alone being consciously managed to do so."
} 
conjunto de competências centrais para a organização. (MINTZBERG; AHLSTRAND; LAMPEL, 1998).

Hamel (1996) argumenta que, no extremo, a criatividade que emerge das pessoas, seria a essência da estratégia. Para o autor organização deve incentivar a busca por novas experiências, por novas perspectivas e por novas formas de ver determinados problemas. Neste sentido, Senge et al. (1935, p. 4, tradução nossa) destacam que "o aprendizado reativo é regido por uma carga de maneiras habituais de pensar e ver o mundo dentro de categorias familiares e confortáveis. ${ }^{\prime 52}$ Desse modo, para os defensores da escola do Aprendizado, a organização aprende por meio da experiência, a partir de feedback que, em última instância, pode promover a emergência de novos padrões de conduta. Contudo, a emergência de novos comportamentos, por si só, não se configura em aprendizado. O aprendizado deve incluir a reflexão e a compreensão da experiência passada, por parte dos agentes (MINTZBERG; AHLSTRAND; LAMPEL, 1998).

Ansoff, Declerck e Hayes (1981), reconhecem que para implementar mudanças em organizações complexas, a aprendizagem se trata de um caminho apropriado. Mas, na visão destes autores, a aprendizagem pode ser planejada e deliberada para atender aos objetivos maiores da organização. Baseados em uma concepção similar, Kaplan e Norton (1997) prescrevem que o aprendizado deve ser composto de um compartilhamento claro de uma visão estratégica bem estruturada, de um bom feedback e de uma boa capacidade de registro dos processos das equipes, quando estas são submetidas a um problema e o solucionam com sucesso.

Diferente das visões prescritivas, a escola do aprendizado vai muito além da ideia de aprendizado deliberado, proposta por Ansoff, Declerck e Hayes (1981) e Kaplan e Norton (1997). De acordo com Hamel (2002), os estrategistas devem se preocupar com as precondições para o surgimento da estratégia, em entender as condições, os princípios que originam a estratégia e, por consequência, as condutas que podem originá-la.

O extremo desta escola incorpora aspectos da teoria do caos, para os quais o aprendizado emerge a partir de perturbações. Sob esta perspectiva os gerentes devem abandonar a concepção de controle, adotada pelas escolas prescritivas, e assumir, não o

\footnotetext{
52 Do inglês: "Reactive learning is governed by downloading habitual ways of thinking, seeing the world within familiar and comfortable categories."
} 
papel de deliberar aprendizado, mas de inserir instabilidades nas organizações de forma a buscar um estado de revolução permanente (MINTZBERG; AHLSTRAND; LAMPEL, 1998).

Hamel (2002) concorda com esta afirmação de que a estratégia está na fronteira entre a ordem e o caos, assim como a vida. Nestas condições, o autor defende que a ordem nas organizações não pode vir detalhada de cima para baixo, ela precisa se estruturar em regras simples e profundas. Mintzberg, Ahlstrand e Lampel (1998, p. 199, tradução nossa) ainda destacam que as estratégias por meio de revoluções também podem contribuir para a definição de estratégias formais, uma vez que "[...] as organizações podem aprender reconhecendo padrões em seus próprios comportamentos, convertendo assim estratégias emergentes do passado em estratégias deliberadas para seu futuro." ${ }^{53}$

Via de regra, há uma concordância ampla de que "a organização que aprende é flexível e aberta" ${ }^{54}$, o que torna o aprendizado vital para o sucesso competitivo na economia global (HITT; IRELAND; HOSKISSON, 2003; JAAFARI, 2003, p. 50). Mas mesmo diante da evidente importância do aprendizado informal "na maioria das empresas o planejamento estratégico é um ritual impulsionado por uma agenda, não uma investigação do potencial para a revolução." 55 (HAMEL, 1996, p. 70) Ainda assim, "entre todas as escolas descritivas, a escola do aprendizado foi aquela que se transformou em uma onda legítima e desafiou as escolas prescritivas, sempre dominantes." ${ }^{56}$ (MINTZBERG; LAMPEL, 1999, p. 25, tradução nossa)

\section{Escola do Poder}

A origem da escola do Poder remete à década de 1970. Os seguidores desta linha de pensamento entendem as estratégias como posições emergentes, com objetivo de iludir e persuadir os interessados, tanto no âmbito interno, como externo à organização. Nesta concepção, as estratégias são um ato político, um processo de negociação e concessão entre indivíduos e organizações (MINTZBERG; AHLSTRAND; LAMPEL, 1998).

\footnotetext{
53 Do inglês: "[...] organizations may learn by recognizing patterns in their own behaviors, thereby converting emergent strategies out of the past into deliberate ones for their future".

${ }^{54}$ Do inglês: "Learning organization are flexible and open."

${ }^{55}$ Do inglês: "In the vast majority of companies, strategic planning is a calendar-driven ritual, not a exploration of the potential for revolution."

${ }^{56}$ Do inglês: "Of all the descriptive schools, the learning school grew into a veritable wave and challenged the always dominant prescriptive school."
} 
Esta escola se apresenta por meio de duas orientações distintas, a do poder macro e a do poder micro.

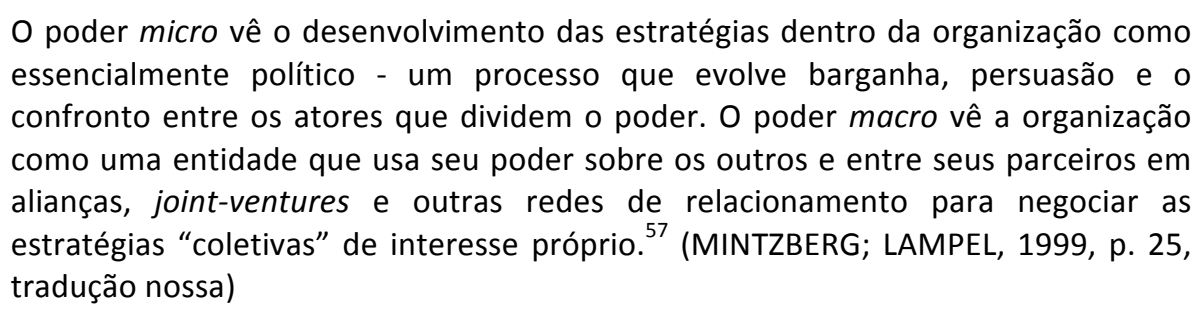

De acordo com as ideias que tratam do poder micro, a política pode ser útil para identificar indivíduos aptos para atuar em cargos de liderança, influenciar o debate entre diversos lados de um problema, estimular as mudanças necessárias à organização e abrir caminho para execução destas mudanças (MINTZBERG; AHLSTRAND; LAMPEL, 1998). Já as visões acerca do poder macro nutrem uma relação estreita com algumas ideias de Porter (1999), principalmente aquelas que propõem manobras visando obter vantagem competitiva por meio da comunicação das intenções da organização. Diante disso, pode-se dizer que esta escola nutre um relacionamento próximo com a escola do Posicionamento. Porém, no lugar de ser baseada em metas econômicas, nesta escola as estratégias são desenvolvidas por meio de intenções políticas que, em última análise, não podem ser tratadas de forma exclusivamente analítica (MINTZBERG; AHLSTRAND; LAMPEL, 1998).

Mintzberg, Ahlstrand e Lampel (1998, p. 241, tradução nossa) destacam que "quanto mais importante a estratégia e descentralizada a organização, mais provável dela ser acompanhada de manobras políticas." ${ }^{58}$ Diante de um ambiente permeado por redes de cooperação e alianças, os ideais desta escola também assumem grande importância, já que neste tipo de cenário as estratégias adquirem um caráter coletivo que, em última instância, depende de profundos processos de negociação (MINTZBERG; AHLSTRAND; LAMPEL, 1998).

\section{Escola Cultural}

A concepção da escola cultural ganhou força na década de 1980, quando o sucesso das organizações japonesas despertou o interesse pela cultura organizacional, como meio de

\footnotetext{
${ }^{57}$ Do inglês: "Micro power sees the development of strategies within the organization as essentially political - a process involving bargaining, persuasion, and confrontation among actor who divided the power. Macro power views the organization as an entity that uses it power over others and among its partners in alliances, jointventures, and other network relationships to negotiate "collective" strategies in its interest."

58 Do inglês: "The more significant the strategy and the more decentralized the organization, the more likely are these to be accompanied by politcal maneuvering."
} 
obtenção de vantagem competitiva. Esta escola vê a formulação da estratégia como um processo de interação social que dá à cultura o papel de mente da organização. Nesta concepção a estratégia assume a característica de perspectiva, baseada nas intenções coletivas da organização. Desse modo, esta escola apresenta uma abordagem inversa à da escola do Posicionamento, já que nesta o foco da estratégia se dá de dentro para fora da organização (MINTZBERG; AHLSTRAND; LAMPEL, 1998; MINTZBERG; LAMPEL, 1999).

A "cultura organizacional diz respeito ao conjunto complexo de ideologias, símbolos e valores centrais, que é compartilhado em toda a empresa e capaz de influenciar a forma pela qual ela conduz os seus negócios." (HITT; IRELAND; HOSKISSON, 2003, p. 36) Ela atua como um filtro perceptivo que delineia o conjunto de decisões dos indivíduos e faz com que a organização opte por metodologias diferentes e abordagens diferentes que levam a tomadas de decisão distintas (MINTZBERG; AHLSTRAND; LAMPEL, 1998).

Para esta escola, "a empresa é um pacote de recursos, tangíveis e intangíveis. O que torna este pacote um sistema único é uma rede de interpretações comuns. São elas que mantêm, renovam e moldam estes recursos." ${ }^{59}$ (MINTZBERG; AHLSTRAND; LAMPEL, 1998, p. 277-278) Neste sentido, Mintzberg, Ahlstrand e Lampel (1998) lembram que a cultura nutre uma forte relação com a parte material da organização, uma vez que os valores, produtos e estruturas, que esta produz, são criados e geridos de acordo com a mesma. Em síntese, ela "[...] representa a força vital da organização, a alma do seu corpo físico." 60 (MINTZBERG; AHLSTRAND; LAMPEL, 1998, p. 266)

Esta escola nutre um forte relacionamento com a escola do aprendizado, onde a cultura pode se desenvolver a partir do processo de aprendizado estratégico. Normalmente este tipo de desenvolvimento se dá por meio de interações sociais tácitas, apesar de poder derivar, em alguns casos, de processos de doutrinação formal. A cultura organizacional também se forma a partir da interação constante com a cultura no meio social que a cerca. (MINTZBERG; AHLSTRAND; LAMPEL, 1998). Deste modo, “[...] nesta escola a formação estratégica se torna a administração da cognição coletiva." 61 (MINTZBERG; AHLSTRAND; LAMPEL, 1998, p. 283)

\footnotetext{
${ }^{59}$ Do inglês: "The firm is thus a bundle of resources, both tangible and intangible. What weaves this bundle into a single system is a web of shared interpretations. That is what maintains, renews, and shapes these resources."

${ }^{60}$ Do inglês: "[...] culture represents the life force of the organization, the soul of its physical body."

${ }^{61}$ Do inglês: "In this school, strategy formation becomes the management of collective cognition."
} 
Uma vez que aspectos materiais podem ser reproduzidos e copiados com certa facilidade, a cultura se configura na principal barreira imposta pelas organizações para evitar a imitação. Deste modo, as dificuldades da própria empresa em delimitar sua cultura acabam por ser sua principal garantia de manutenção de vantagem estratégica. Uma cultura rica distingue a empresa das demais e pode promover perspectivas estratégicas estáveis que levam a vantagens competitivas para a organização. Contudo, a estabilidade promovida por uma cultura rica atua como um bloqueio ao aprendizado e à mudança, uma vez que a crença estabelecida a respeito do que funcionou no passado pode encorajar a resistência a novas abordagens (MINTZBERG; AHLSTRAND; LAMPEL, 1998).

\section{Escola Ambiental}

Esta escola coloca o ambiente como o agente central na formação da estratégia. Nela a organização luta por recursos com outras organizações, em um sistema similar aos nichos ecológicos adotados pela biologia. Desse modo, a estratégia é tratada por meio de uma visão ecológica, onde a organização deve se adaptar ao meio para não ser eliminada por ele (MINTZBERG; AHLSTRAND; LAMPEL, 1998). Neste sentido, ela entende que "a evolução oferece uma receita poderosa e eficaz para a resolução de problemas e para a criação de estratégias em um ambiente imprevisível." (BEINHOCKER, 2002, p. 154)

Apesar de seu foco competitivo, a escola Ambiental difere da escola do Posicionamento, pois nela, a estratégia se desenvolve com base nas deficiências da organização frente ao meio e não na fortificação de posições de mercado (MINTZBERG; AHLSTRAND; LAMPEL, 1998). Esta linha de pensamento vê nos graus de liberdade de ação da empresa, frente às contingências do meio, o componente fundamental para garantir a perenidade da organização. (MINTZBERG; LAMPEL, 1999)

Neste contexto, “[...] o pensamento coletivo é a morte da diversidade estratégica. Não apenas a diversidade demográfica (idade, sexo, raça, nacionalidade etc), mas uma diversidade de experiências.[...] A diversidade deve ser vista como um investimento e cultivada ativamente." (BEINHOCKER, 2002, p. 150) Beinhocker (2002) propõe, então, que as organizações devem trocar a concepção do foco pela variedade. Para o autor, uso de múltiplas estratégias, capazes de evoluir com o passar do tempo, como ocorre na evolução das espécies, pode apresentar melhores resultados em cenários complexos do que 
estratégias de foco único, pois mantém uma série de possibilidades em aberto para a organização.

Contudo, esta escola padece de certos exageros. Diante dela a organização está sujeita, exclusivamente, a imperativos ambientais e as estratégias se desenvolvem por meio de um processo passivo (MINTZBERG; AHLSTRAND; LAMPEL, 1998). Até mesmo as concepções ecológicas contemporâneas, como a teoria de Gaia de Lovelock (2000), têm substituído a concepção de evolução determinada pelo meio para uma concepção de coevolução. Em uma concepção co-evolucionista, o ambiente é formado pelas próprias organizações. Portanto, estas não podem ser consideradas completamente passivas, uma vez que possuem tanto a capacidade de definir o ambiente como, por consequência, a si próprias (MINTZBERG; AHLSTRAND; LAMPEL, 1998).

\section{Escola da Configuração}

A escola da configuração consiste em uma abordagem integrativa, que vê a empresa como um agrupamento de características e comportamentos. Nela a estratégia é descrita por meio de sua estabilidade relativa e de um processo ocasional de transformação dos estados na organização (MINTZBERG; AHLSTRAND; LAMPEL, 1998).

$\mathrm{Na}$ concepção desta escola, a ação empreendedora leva a uma acomodação da organização diante do sucesso que, por sua vez, pode desencadear crises que originam novos ciclos empreendedores e assim sucessivamente. Desse modo, as organizações podem ser descritas em termos de características estáveis, que são interrompidas por períodos de instabilidade. Pode-se dizer então, que as organizações precisam conviver com ciclos de sucesso e fracasso, onde se faz necessário equilibrar os aspectos da mudança e da continuidade. Sob esta perspectiva, a chave da estratégia é manter a estabilidade, mas sem negligenciar a periódica necessidade de mudanças (MINTZBERG; AHLSTRAND; LAMPEL, 1998).

Para conciliar situações tão antagônicas a escola da configuração combina literaturas prescritivas e descritivas, com o objetivo de entender o processo estratégico como uma configuração específica entre diferentes constructos, desenvolvidos pela literatura das demais linhas de pensamento. Contudo sua abordagem trata a organização de forma simplista e opera em extremos. Para ela a empresa em mudança se encontra em desequilíbrio indesejável (MINTZBERG; AHLSTRAND; LAMPEL, 1998; MINTZBERG; LAMPEL, 
1999). Portanto, esta escola renega a mudança incremental, já que esta estaria em desacordo com o ideal de busca pelo equilíbrio, adotado pelos adeptos deste ponto de vista.

\subsubsection{O processo estratégico}

Na concepção de Mintzberg, Ahlstrand e Lampel (1998) e Mintzberg e Lampel (1999),

a dez escolas de pensamento encontradas por meio de seus esforços, compõem, a sua maneira, partes importantes do processo estratégico nas organizações. Juntos, estes dez pontos de vista abrangem a estratégia como plano, padrão, perspectiva e posição e, também, diversos dos processos necessários para lidar com partes importantes do problema - ver quadro 5.

\begin{tabular}{|c|c|c|c|c|}
\hline Escola & Estratégia & Processo básico & Mudança & Agente central \\
\hline Design & $\begin{array}{c}\text { Perspectiva } \\
\text { planejada, única }\end{array}$ & $\begin{array}{l}\text { Cerebral, simples, } \\
\text { deliberado e } \\
\text { informal }\end{array}$ & Ocasional em saltos & $\begin{array}{l}\text { Executivo } \\
\text { Principal }\end{array}$ \\
\hline Planejamento & $\begin{array}{c}\text { Planos } \\
\text { decompostos }\end{array}$ & $\begin{array}{l}\text { Formal, } \\
\text { decomposto, } \\
\text { deliberado }\end{array}$ & Periódica, incremental & Planejadores \\
\hline Posicionamento & $\begin{array}{l}\text { Posições genéricas } \\
\text { planejadas }\end{array}$ & Analítico, deliberado & Pequenas e frequentes & Analistas \\
\hline Empreendedora & $\begin{array}{l}\text { Perspectiva } \\
\text { pessoal única }\end{array}$ & $\begin{array}{l}\text { Visionário, intuitivo } \\
\text { e deliberado }\end{array}$ & $\begin{array}{l}\text { Oportunista e } \\
\text { revolucionária }\end{array}$ & Líder \\
\hline Cognitiva & Perspectiva mental & Mental, emergente & $\begin{array}{c}\text { Enfrenta resistência } \\
\text { mental }\end{array}$ & $\begin{array}{c}\text { Mente do } \\
\text { estrategista }\end{array}$ \\
\hline Aprendizado & Padrão, única & $\begin{array}{c}\text { Emergente, } \\
\text { informal, confuso }\end{array}$ & $\begin{array}{l}\text { Contínua, incremental e } \\
\text { ocasional em saltos }\end{array}$ & $\begin{array}{c}\text { Aqueles dispostos } \\
\text { a aprender }\end{array}$ \\
\hline Poder & $\begin{array}{l}\text { Padrão e posição } \\
\text { política }\end{array}$ & $\begin{array}{l}\text { Agressivo, } \\
\text { emergente e } \\
\text { deliberado } \\
\end{array}$ & Pequenas e frequentes & $\begin{array}{l}\text { Pessoas com } \\
\text { poder e } \\
\text { organização }\end{array}$ \\
\hline Cultural & $\begin{array}{l}\text { Perspectiva } \\
\text { coletiva única }\end{array}$ & $\begin{array}{l}\text { Ideológico, forçado, } \\
\text { coletivo, deliberado }\end{array}$ & $\begin{array}{l}\text { Enfrenta resistência } \\
\text { ideológica }\end{array}$ & Coletividade \\
\hline Ambiental & $\begin{array}{l}\text { Posições } \\
\text { específicas }\end{array}$ & $\begin{array}{l}\text { Passivo, imposto, } \\
\text { emergente }\end{array}$ & $\begin{array}{l}\text { Raras, em saltos e } \\
\text { graduais }\end{array}$ & Ambiente \\
\hline Configuração & $\begin{array}{c}\text { Posição, } \\
\text { Perspectiva, plano } \\
\text { e padrão }\end{array}$ & $\begin{array}{l}\text { Interativo, baseado } \\
\text { em todos os } \\
\text { anteriores }\end{array}$ & $\begin{array}{c}\text { Ocasional, revolucionária } \\
\text { e, em alguns casos, } \\
\text { incremental }\end{array}$ & $\begin{array}{l}\text { Todos os } \\
\text { anteriores }\end{array}$ \\
\hline
\end{tabular}

Quadro 5 - Principais aspectos das dez escolas de pensamento estratégico, segundo Mintzberg, Ahlstrand e Lampel (1998)

Fonte: Mintzberg, Ahlstrand e Lampel (1998, p. 356-357, tradução nossa) 
Com base nestas perspectivas, Mintzberg, Ahlstrand e Lampel (1998, p. 372-373, tradução nossa) constataram a estratégia é um amplo processo arbitrário que abrange:

[...] uma visão intuitiva e um aprendizado intuitivo; ela abarca transformação e também perpetuação; envolve cognição individual e interação social, cooperação e também conflito; ela precisa incluir análise antes e programação depois, bem como negociação durante; e tudo isso em resposta àquele que pode ser um ambiente exigente. $^{62}$

Mintzberg, Ahlstrand e Lampel (1998) e Mintzberg e Lampel (1999) realizaram, então, um mapeamento, em duas dimensões, sobre como cada uma das abordagens se distribui com relação aos processos internos e às condições externas às organizações - ver gráfico 2. A partir deste mapeamento fica evidente que cada escola lida com aspectos específicos destas duas dimensões.

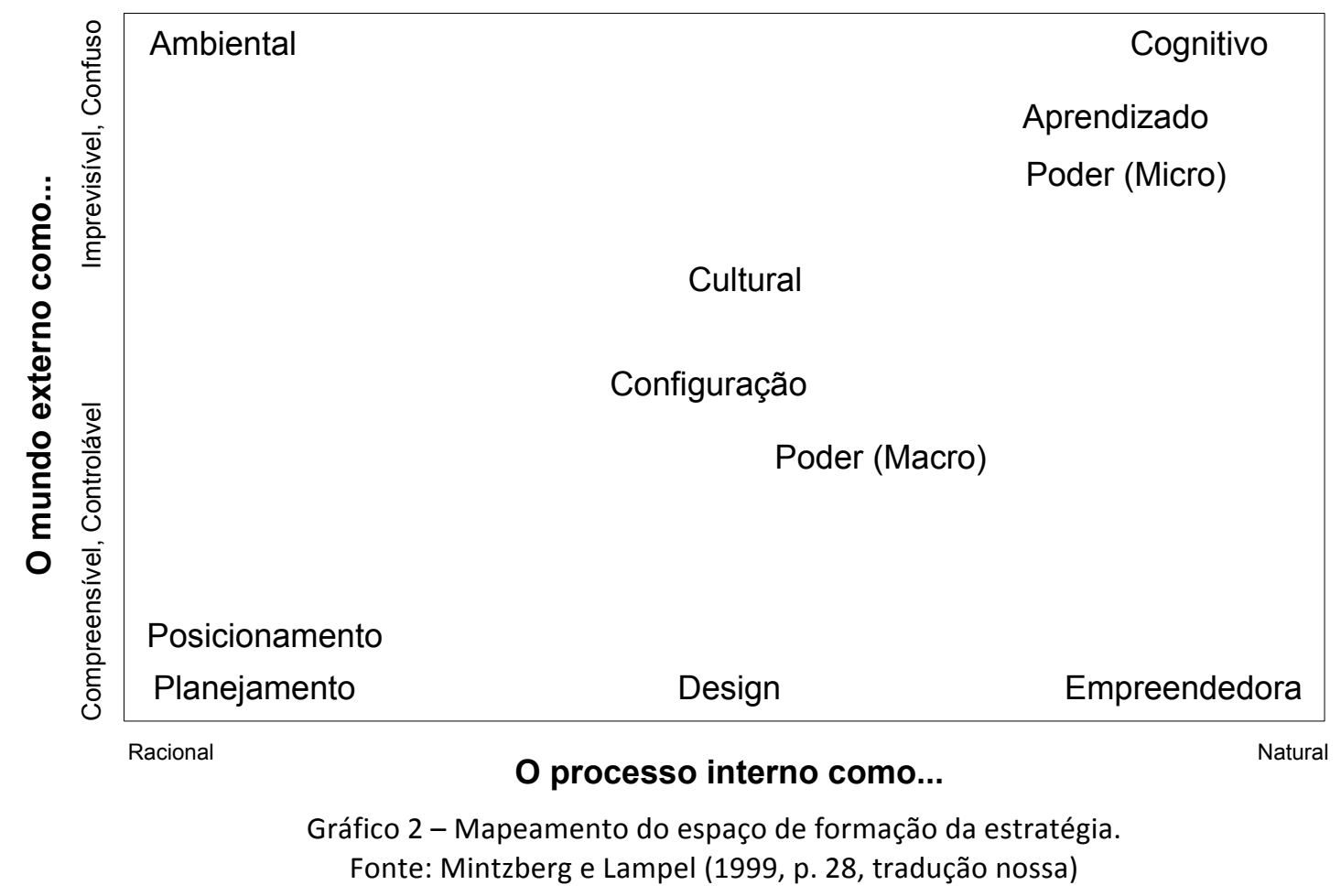

Mintzberg e Lampel (1999) constataram, então, que mesmo diante das enormes contribuições dadas por cada uma destas escolas, elas não podem contemplar, por si só, todos os aspectos do processo estratégico. Os autores alegam que para construir uma

\footnotetext{
${ }^{62}$ Do inglês: “[...] intuitive visioning, and emergent learning; it is about transformation as well as perpetuation; it must involve individual cognition and social interaction, cooperation as well as conflict; it hás to incude analyzing before and programming after as well as negotiating during; and all of this must be in response to what can be a demanding environment."
} 
imagem robusta deste processo "[...] temos que ir além das limitações de cada escola: precisamos saber como a formação da estratégia, que combina todas essas escolas e mais outros fatores, realmente funciona." ${ }^{63}$ (MINTZBERG; LAMPEL, 1999, p. 29) Com base neste princípio Mintzberg, Ahlstrand e Lampel (1998) e Mintzberg e Lampel (1999) propuseram uma imagem integrativa do processo, onde a escola Cognitiva representa a "caixa preta" da formulação da estratégia e seus princípios ocupam o centro do processo de formação das estratégia, enquanto as demais escolas ocupam seu lugar ao redor da mesma - ver figura 13.

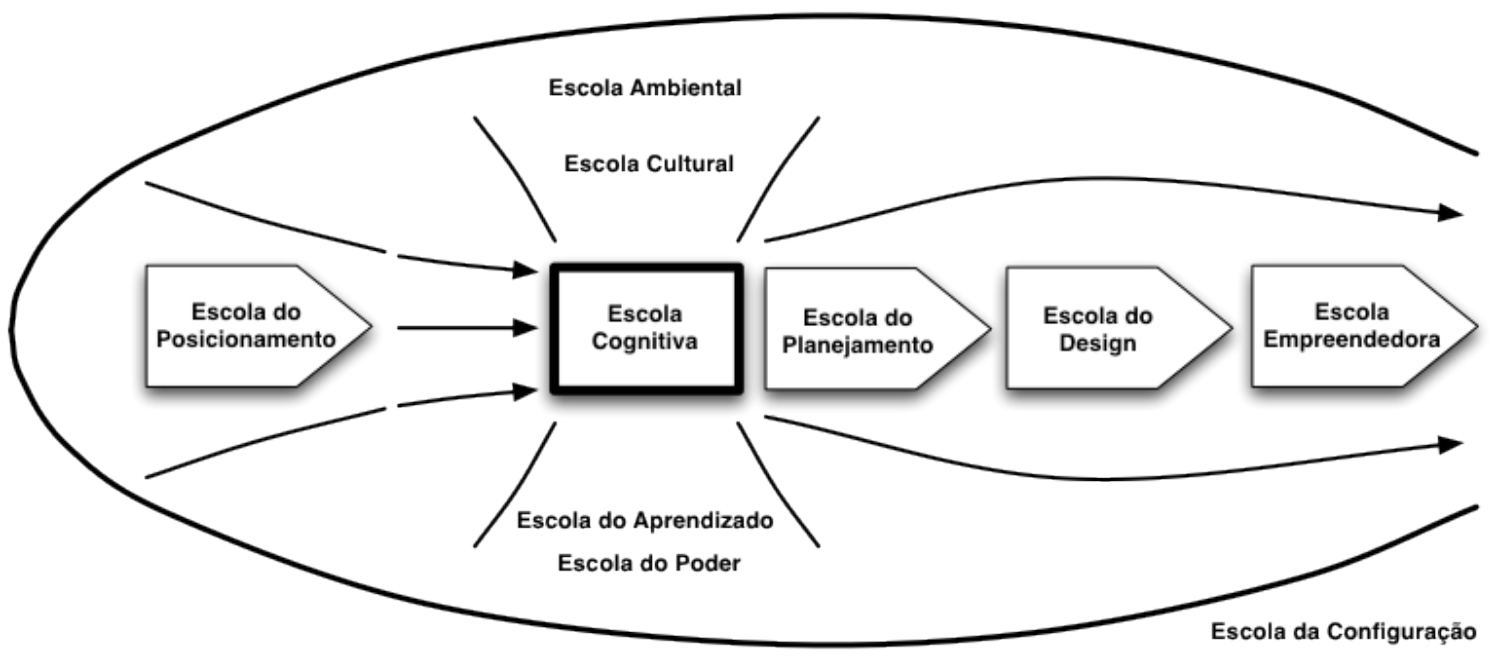

Figura 13 - A formação da estratégia como um único processo Fonte: Mintzberg e Lampel (1999, p. 27, tradução nossa)

Neste modelo proposto por Mintzberg, Ahlstrand e Lampel (1998) e Mintzberg e Lampel (1999), a escola do posicionamento se ocupa de alimentar a formulação da estratégia, por meio de análises, dados históricos e de mercado. As escolas que se seguem Planejamento, Design e Empreendedora - visam programar a visão de futuro da organização. Enquanto a escola do Planejamento olha para o futuro próximo, a escola do Design busca uma perspectiva mais distante e a Empreendedora estabelece uma visão única de futuro, além daquela programada pelas primeiras.

As escolas Ambiental, Cultural, do Aprendizado e do Poder, abordam o problema por sobre a "caixa preta", contemplando aspectos ambientais e suas implicações para a cognição dos tomadores de decisão, ou por baixo dela, se apegando a detalhes do processo de formação de estratégias. Por fim a escola da configuração abrange todo o processo com foco

63 Do inglês: "[...] we have to get beyond the narrowness of each school: we need to know how strategy formation, which combines all these schools and more, really works." 
na estrutura e fora dela (MINTZBERG; AHLSTRAND; LAMPEL, 1998; MINTZBERG; LAMPEL, 1999).

Esta concepção do processo se apresenta com grande valia para os objetivos deste esforço de pesquisa, uma vez que o processo estratégico é uma das dimensões do problema estratégico, propriamente dito. Portanto, qualquer descrição acerca do mesmo acaba por contemplar, mesmo que de forma superficial, algum aspecto do processo. Tal tipo de contribuição também é importante, pois os mecanismos utilizados pelas organizações, para responder às transformações às quais se encontram submetidas, também podem ser utilizados para validar possíveis descrições dos aspectos internos e externos e das variáveis do problema.

\subsection{A ESTRATÉGIA E A COMPLEXIDADE}

Durante o século XX o pensamento predominante foi aquele de origem cartesiana (JASPERS, 1976; CAPRA, 1983; KUHN, 1996). Foi mediante este paradigma que Frederick Taylor deu início aos seus experimentos que deram origem àquilo que foi denominado de administração científica (MILLER, 1987; BATEMAN; SNELL, 1998, 2006). Como era de se esperar, Taylor levou a concepção do homem máquina à administração, onde os conceitos cartesianos de rendimento da termodinâmica de Carnot, foram transportados para as questões relacionadas ao rendimento do ser humano médio (BAUER, 1999).

Grande parte das abordagens clássicas de gestão seguiram os mesmos passos daquelas adotadas por Taylor. As concepções do casal Gilbreth e de Henry Ford, por exemplo, eram centradas na racionalização e fragmentação das tarefas, enquanto Henri Fayol dava ênfase na estrutura e no gerenciamento e Max Weber na configuração da organização em termos de unidades (CARAVANTES; PANNO; KLOECKNER, 2005). 
Como era de se esperar estas concepções cartesianas também acabaram presentes nas ideias de Alfred Chandler (CLEGG; CARTER; KORNBERGER, 2004). Conforme visto anteriormente, Chandler é o fundador da escola Design cujas ideias centrais repercutem por todo o pensamento estratégico prescritivo. Desse modo:

\begin{abstract}
da mesma maneira que Frederick Taylor havia transformado uma montagem complexa em algo que poderia ser repetido, decompondo-a em tarefas simples, a nova doutrina [da estratégia], o equivalente gerencial do Taylorismo, visava fazer da gerência de empresas complexas algo sistemático e previsível. Uma vez definida a estratégia, as estruturas e sistemas baniriam as idiossincrasias humanas problemáticas, permitindo, assim, que as empresas de grande porte, e diversificadas, fossem administradas como uma máquina. (GHOSHAL; BERTLETT; MORAN, 2002, p. 21)
\end{abstract}

Mesmo Ansoff e Hayes (1981) - autores clássicos da escola do planejamento reconhecem que esta abordagem cartesiana do planejamento estratégico se mostra limitada, por abranger apenas parte do problema. Os autores ressaltam que para atender às novas dimensões percebidas no contexto contemporâneo, as variáveis psicológicas, sociológicas e políticas, antes excluídas, vêm se mostrando importantes para o cenário de gestão. Diante deste contexto, Thiollent (1983, p. 81-82) constatou que "sendo a organização uma totalidade na qual se manifestam fenômenos de tomada de consciência, afetividade e criatividade, torna-se muito difícil e até equivocado o isolamento de variáveis."

Com o surgimento da teoria dos sistemas emergiram novas linhas de pensamento que visavam descrever os fenômenos sociais a partir de tecnologia sistêmica e até mesmo holística (CAPRA, 1983; MINTZBERG; AHLSTRAND; LAMPEL, 1998; JAAFARI, 2003). Desde então, diversos autores da área de estratégia trabalharam sobre os alicerces do caos, da complexidade e da teoria da evolução (MINTZBERG; AHLSTRAND; LAMPEL, 1998; MINTZBERG; LAMPEL, 1999).

Nas abordagens complexas, “a palavra estratégia se opõe à programa. [...] 0 programa não obriga a estar vigilante. Ele não obriga a inovar." (MORIN, 2007c, p. 81)

\footnotetext{
Um programa não passa de uma sequência de ações predeterminadas, ou seja, só pode ser bem-sucedido em ambientes com muita ordem e pouca desordem. Já uma estratégia é produzida pelo exame simultâneo das condições determinadas (ordem) e incertezas (desordem), e cria a ação. (BAUER, 1999, p. 54)
}

No sentido da complexidade, a estratégia se trata, então, de toda a ação empreendida por uma determinada forma de organização. Em condições estáveis os programas, conforme propostos pelo ideal da estratégia como plano, podem ser suficientes 
para dar conta das anomalias, mas em condições incertas somente a estratégia vista como ação, pode dar conta de garantir a perpetuidade da organização (MORIN, 2007c).

Portanto, na perspectiva da complexidade a estratégia assume uma definição que vai além dos dois eixos propostos por Mintzberg Ahlstrand e Lampel (1998). Nela estratégia envolve realização, abrange controle e emergência, pode olhar tanto para dentro como para fora da organização, pode se configurar como truque ou qualquer outro ato ou processo. Neste sentido, desponta a percepção de que a visão de estratégia como ação é sinérgica com a concepção de estratégia como padrão, ao passo que só pode ser reconhecida pelo que é realizado, ou seja, só pode ser identificada a partir de sua execução. Diante desta constatação, a afirmação de Hamel (1998), a respeito da incapacidade dos estudiosos de reconhecer uma estratégia antes que a vejam, se mostra uma realidade insuperável diante de uma compreensão complexa da mesma.

Desse modo, o grande problema da visão clássica, pode ser exatamente a ideia de um processo focado na construção de um plano. Diante da concepção de estratégia como ação, a visão linear de mundo, adotada pelas abordagens do planejamento, acaba por ser insuficiente para lidar com o problema da governança em ambientes instáveis e ricamente perturbados. Contudo, observa-se que, mesmo as tratativas contemporâneas de gestão que reconhecem na mudança algo inerente à natureza da sociedade -, ainda carregam elementos típicos da visão fragmentadora dos paradigmas de origem cartesiana, o que diminui sua eficácia na compreensão sistêmica da realidade organizacional (DRUCKER, 2003; HURTADO, 2006).

Os trabalhos de Hurtado (2006) e Faria (2005) dão indícios de que para construir uma síntese do complexo que envolve o problema estratégico, é necessário que haja uma reestruturação da própria postura da administração como ciência. É preciso abandonar o pensamento em unidades de análise ou casos/soluções isolados, como é praxe até mesmo nos estudos sistêmicos da área de gestão. Neste sentido, Nowotny (2005, p. 29, tradução nossa) argumenta que para a ascensão deste novo tipo de conhecimento é "[...] necessário um profundo entendimento teórico da complexidade, não como um fenômeno matemático e sim como um fenômeno social." ${ }^{64}$

64 Do Inglês: "A deeper theoretical understanding of complexity, not as a mathematical, but as a social phenomenon is required." 
De acordo com Faria (2005, p. 63) os pesquisadores da área de gestão "devem transcender disputas epistemológicas e reconhecer elementos causais tidos como "não empíricos" ou "invisíveis"”, incompatíveis com os paradigmas de origem positivista/cartesiana que dominam a ciência da administração desde seus primórdios. Os elementos "não empíricos" da realidade, exigem uma perspectiva capaz de transportar os conteúdos das interpretações individuais ao âmbito do familiar e imediatamente compreensível. Com isso, "um novo caminho torn[a]-se particularmente rico: a busca de 'interfaces'." (CASANOVA, 2006, p. 31).

Neste sentido, Nowotny (2005) ressalta que em um contexto complexo a interface entre as ciências naturais e as ciências humanas tem um papel estratégico na compreensão das interações sistêmicas entre a sociedade e a natureza.

\footnotetext{
É evidente que os seres humanos, ao contrário das moléculas, são capazes de imaginar, inventar, criar correlações, ou seja, são capazes de se propor os problemas que vivem. Não se pode sequer conceber, portanto, a ideia de uma redução do fenômeno humano a parâmetros físico-químicos; ao contrário, trata-se de perceber que as noções de acontecimento e de sua consequência (a evolução) são noções comuns a todas as ciências, naturais ou sociais, que se deparam com a questão das populações, ou seja, do ser e estar juntos. Assim, o que desponta é a perspectiva de uma articulação entre ciências distintas na medida em que estas se defrontam com problemas de natureza comum. (BAUER, 1999, p. 146)
}

Na década de 1980, Capra (1983) se baseou em uma abordagem multidisciplinar, muito bem estruturada, para construir uma visão que articulava preceitos da física quântica e da biologia com a nova realidade dos sistemas sociais e do pensamento humano. Suas voltas através do universo das ciências naturais, o levaram à transição das partes ao todo dos sócios-sistemas e permitiram que o autor propusesse uma nova perspectiva acerca das relações sociais. O trabalho do autor produziu previsões bem sucedidas de muitas das problemáticas vividas pela sociedade contemporânea, o que reforça o ponto de vista de que este tipo de tratativa se mostra apropriada para a construção do conhecimento no ambiente social.

Nas ciências das organizações Bauer (1999) se aproveitou de grande parte das ideias de Capra (1983) para desenvolver um entendimento inicial, também de caráter multidisciplinar, da dinâmica das mudanças dentro das organizações. Seu trabalho partiu de uma postura dialética e demonstrou que muitas das dinâmicas organizacionais poderiam ser enquadradas de acordo com preceitos da nova biologia e da nova matemática, como ordem pelo ruído, autopoiese e auto-organização. 
Apesar da evidente necessidade de emergência de uma nova concepção acerca da estratégia e dos esforços contemporâneos da área da gestão, para incorporar a mudança de forma adequada ao seu vocabulário, Stacey (1995) lembra que a ciência na área de gerenciamento ainda é tipicamente reducionista. Neste sentido, os cenários contemporâneos exigem aquilo que já havia sido identificado previamente por Mintzberg Ahlstrand e Lampel (1998), uma concepção acerca do problema que transcenda a "costura" das principais escolas de pensamento da área e explore os aspectos dinâmicos que regem a vida da estratégia, assim como Bauer (1999) desenvolveu com relação às dinâmicas internas da organização. 


\section{PROCEDIMENTOS DE PESQUISA}

Inicialmente, é importante ressaltar que o presente esforço de pesquisa foi alicerçado com o objetivo de descrever a dinâmica do problema estratégico, a partir das perspectivas ontológicas, epistemológicas e metodológicas da complexidade. Conforme mostrado no capítulo 2.5, a síntese da totalidade do fenômeno, obtida por meio da integração, consiste em um aspecto relevante para a construção do conhecimento complexo que, de acordo com Devlin (1996), exige o abandono do ideal cartesiano de ciência. Portanto, o presente esforço de pesquisa trata-se de uma pesquisa de natureza descritiva, cujos fundamentos epistemológicos e ontológicos - ver quadro 6 - diferem significativamente do paradigma adotado tradicionalmente pela ciência clássica - ver capítulo 2.5 .

\begin{tabular}{lc}
\hline \multicolumn{2}{c}{ Fundamentos epistemológicos da complexidade, adotados pelo presente esforço de pesquisa } \\
\hline Foco de estudo & Relações \\
Sujeito/Objeto & Indissociáveis \\
Preceito & Integração $\Leftrightarrow$ Desintegração \\
Hemisfério cerebral dominante & Direito $\Leftrightarrow$ Esquerdo \\
Conhecimento & Intuitivo \\
Inferência predominante & Dedutiva \\
Causalidade & Recursiva \\
Modelos & Não-lineares \\
Linguagem & Simbólica \\
\hline Quadro 6 - Fundamentos epistemológicos da complexidade, adotados pelo presente esforço de pesquisa
\end{tabular}

A principal diferença entre os métodos clássicos e o método de pesquisa adotado neste trabalho, se encontra na ideia de que "as propriedades das partes não são propriedades intrínsecas, mas só podem ser entendidas dentro do contexto do todo mais amplo." (CAPRA, 2006, p. 41) Devido a isso, o foco deste estudo não se deu na descrição dos objetos e sim na descrição da dinâmica das relações entre as unidades do problema. Este tipo de fundamentação exige um tipo de apreensão do conhecimento que não se manifesta por meio das abordagens empiristas, mas somente por meio da intuição - ver capítulo 2.5. 
Tal particularidade, associada ao caráter descritivo da pesquisa e à indissociabilidade entre sujeito e objeto, apregoada pelo novo espírito científico, conduziu este esforço de pesquisa à adoção do método de redução fenomenológica de Husserl, como base para a coleta e análise de evidências. Essencialmente, o método fenomenológico se trata de um método descritivo de natureza qualitativa, que utiliza meios não-experimentais para a construção do conhecimento (GILES, 1989; MOREIRA, 2002).

Os estudos acerca da fenomenologia tiveram sua origem na busca do matemático Edmund Husserl por um método que the permitisse chegar a "[...] uma ciência verdadeiramente fundamentada em bases últimas e absolutas." (ZITKOSKI, 1994, p. 17) Para tal, Husserl partiu da premissa que os fenômenos são "[...] as formas de estar consciente de algo e todos os seus constituintes [...]" (HUSSERL, 2001; MOREIRA, 2002, p. 64). Nesta concepção, os fenômenos não se tratam dos objetos em si e sim da forma com a qual estes são percebidos pela consciência do observador, forma esta que não se constitui em uma mera aparência e possui natureza própria (HUSSERL, 2001; MOREIRA, 2002). Portanto, podese dizer que a fenomenologia de Husserl busca "[...] a investigação direta e a descrição dos fenômenos como experimentos de consciência." (MOREIRA, 2002, p. 67)

A adoção desta abordagem levou Husserl (2001) à conclusão de que só é possível ter acesso às descrições dos fenômenos a partir do acesso direto aos conteúdos da consciência do observador. Deste modo, a descrição dos fenômenos não seria possível sem que antes fosse explicitado "[...] o funcionamento do fluxo intencional que abarca toda a vida consciente do ego e do cogito." (ZITKOSKI, 1994, p. 55; HUSSERL, 2001).

Husserl (2001) propôs, então, que o juízo fenomenológico deveria ser precedido de um processo de desconexão do pesquisador com suas perspectivas prévias acerca da existência de um universo externo, até a fonte última dos sentidos e valores possíveis a serem atribuídos a um objeto. Para tal o pesquisador precisa ignorar as concepções que possui do objeto, mesmo aquelas tidas como verdades evidentes. Husserl (2001) denominou este processo de epoché e para ele este é o único caminho para a fundamentação rigorosa, na qual a apodicidade - tida pelo autor não como a evidência, mas como a auto-evidência oferece o máximo grau de certeza. Portanto, a epoché, como subjetividade reduzida, é um critério essencial para os estudos da esfera fenomenológica (ZITKOSKI, 1994).

Merleau-Ponty (1999) destaca que o processo de busca pelo desligamento, proposto pela epoché, esbarra em sérias dificuldades práticas, já que a própria consciência do 
pesquisador atua como ruído na busca por uma evidência final. Para lidar com este problema o autor propõe que a evidência fenomenológica requer o reconhecimento da intencionalidade do ser, pois só assim é possível reconhecer a evidência em meio ao ruído provocado pelos conteúdos da consciência (MERLEAU-PONTY, 1999; MOREIRA, 2002). Tal perspectiva está de acordo com as concepções de Devlin (1996) para quem o observador não consegue lidar com uma situação prática de forma desconexa de suas experiências, já que a "[...] experiência prévia se trata de uma condição necessária para interpretarmos o mundo como um todo." ${ }^{65}$ (DEVLIN, 1996, p. 347, tradução nossa)

Neste contexto, a única forma de se alcançar os objetivos da fenomenologia, oriunda do pensamento de Husserl, seria através do reconhecimento da intencionalidade e dos limites da consciência do ser, que em última instância seria fruto da realidade social do observador. Então a fenomenologia carrega em seu cerne o reconhecimento da "intencionalidade da consciência” e, por consequência, o reconhecimento das dificuldades inerentes à busca pela neutralidade científica e pela verdade absoluta, uma vez que o homem passa a ser incluído como agente reflexivo no processo (HUSSERL, 2001; MOREIRA, 2002, p. 71).

Destarte, na perspectiva fenomenológica "a ciência não tem e não terá jamais o mesmo sentido de ser que o mundo percebido, pela simples razão de que ela é uma determinação ou uma explicação dele", dada sob a ótica do observador (MERLEAU-PONTY, 1999, p. 3). A fenomenologia reconhece na transitoriedade do ser a transitoriedade da própria realidade, uma vez que os limites na redutibilidade da intencionalidade, se colocam como fronteiras para o próprio alcance dos fatos por trás da realidade percebida.

Portanto, a fenomenologia de Husserl carrega em seu cerne um revolucionário caráter ontológico e epistemológico, onde os aspectos transitórios da consciência levam à transitoriedade do objeto reconhecido e a uma impossibilidade de se alcançar o conhecimento verdadeiro. Pode-se dizer, então, que a fenomenologia está em sintonia com os ideais do novo espírito científico, ao passo que reconhece que o conhecimento acerca do mundo social está limitado pela interpretação do sujeito, assim como o conhecimento do mundo natural encontra-se limitado pela interação entre objeto e observador.

\footnotetext{
${ }^{65}$ Do inglês: "[...] prior experiences are a necessary condition for us to interpret the world at all."
} 
Tal perspectiva difere radicalmente do pensamento cartesiano, que pregava uma consciência desprovida de intencionalidade, capaz de explicitar os fenômenos de forma clara e transparente e apregoava a possibilidade de uma ciência neutra e imparcial. O método fenomenológico, ao contrário, parte da premissa que existe um forte caráter de intencional na ciência.

Uma vez que a percepção sensorial se encontra permeada do ruído da consciência, o método fenomenológico assume uma postura onde o que se manifesta aos sentidos não pode ser tratado como uma expressão dos fatos, conforme proposto pelo método cartesiano. Para a fenomenologia de Husserl é somente na intuição que se encontra a representação direta e imediata do objeto. Assim, as lacunas de um ato de juízo intencional devem ser preenchidas por meio dela e não pelo que é percebido pelos sentidos. Em outras palavras, a evidência fenomenológica emerge a partir do preenchimento intuitivo de lacunas nos conteúdos da consciência. Em síntese, "no dinamismo da intencionalidade [...], a evidência desponta como um tipo especial de juízo." (ZITKOSKI, 1994, p. 22)

Neste sentido, Husserl (2001) concluiu que a intuição das essências, que denominou de intuição eidética, consiste no caminho para uma descrição rigorosamente fundamentada dos fenômenos. Para se atingir esta descrição o autor propôs um método de redução onde se busca distinguir, na intuição, os aspectos invariantes de um dado objeto. Este processo, denominado de redução eidética, se dá por meio da eliminação de qualquer característica que não seja fundamental para que o fenômeno seja reconhecido tal como o é (ZITKOSKI, 1994; HUSSERL, 2001).

Como exemplo se pode tomar uma xícara. Sua cor ou desenhos nela estampados, não modificam o objeto xícara em sua essência. Ao remover tais atributos ela ainda se revela ao observador como uma xícara. Porém, ao remover a imagem da asa, a xícara assume a essência de um copo. Portanto, o processo de redução eidética revela que características como cor ou desenhos não são componentes da essência primeira de uma xícara, enquanto a asa é um aspecto descritivo importante para que ela seja reconhecida como tal. É possível afirmar, então, que na evidência eidética a descrição do fenômeno é obtida por meio das relações internas e externas das essências dos fenômenos (GILES, 1989; ZITKOSKI, 1994; MERLEAU-PONTY, 1999; MOREIRA, 2002)

Conforme lembra Husserl (2001) intuição eidética se trata de uma síntese dos fenômenos que atinge todo o sentido possível a uma evidência e é esta característica que 
garante à fenomenologia a fundamentação rigorosa que lhe confere grau de ciência (ZITKOSKI, 1994). Sob a concepção fenomenológica a evidência se manifesta por meio do juízo do pesquisador. Portanto, o método fenomenológico liberta o pesquisador da preocupação de encontrar sentido e estruturar suas fontes e seus experimentos, já que os conteúdos de sua própria consciência, preenchidos por meio da intuição, se constituem em sua principal fonte de informação e, portanto, o objeto a ser estruturado para se tornar inteligível.

Neste ponto é importante ressaltar que a intuição não nega o aspecto racional do pesquisador. A intuição é o oposto polar dos sentidos, capaz de produzir totalizações às quais estes são incapazes de construir (JUNG, 1971). Uma vez que a intuição não se reflete em um antagônico da razão e sim dos sentidos, o juízo fenomenológico também não pode ser considerado oposto a esta. Portanto, assumir a fenomenologia como postura investigativa, não significa que o esforço para organizar e classificar os conteúdos da consciência dispense reflexões acerca do problema, mesmo porque, a própria necessidade de se reconhecer elementos comuns nos conteúdos da consciência, torna imperativa a presença de um espaço reflexivo para organizar e classificar os conteúdos da consciência de forma a torná-los inteligíveis. Tal conciliação também é fundamental para atender aos anseios da complexidade, cuja perspectiva é a base do presente esforço de pesquisa .

Como meio de descrever os conteúdos da consciência de forma acessível, este esforço de pesquisa buscou se utilizar de um método de análise que pudesse se manifestar por meio de um elo comum entre a evidência fenomenológica e os aspectos exigidos pela inferência dedutiva. Este elo comum teve como objetivo possibilitar a classificação e organização da descrição, de forma que esta pudesse ser compreendido e analisada diante de aspectos já familiares ao pesquisador. Neste cenário as analogias se destacaram, já que permitem transportar as similaridades entre os diversos níveis sistêmicos e possibilitam a compreensão simplificada dos fenômenos mais complexos, inerentes à totalidade, a partir de fenômenos já conhecidos.

De acordo com Husserl (2001) "todo elemento de nossa experiência cotidiana oculta uma transposição por analogia do sentido objetivo, originalmente criada, no novo caso, e contem uma antecipação do sentido desse último como o de um objeto análogo." Quando há a revelação de que o sentido apreendido por meio do análogo se trata de um sentido novo, isso remete a formulação da ideia de criação primeira. Portanto, na concepção 
fenomenológica as analogias ocorreriam por meio de uma percepção assimiladora que, em última instância, possibilitaria relacionar diretamente o objeto desconhecido a um grupo previamente conhecido de objetos (HUSSERL, 2001, p. 125).

De acordo com Genter et al. (2001) as metáforas se constituem em um processo oriundo do mesmo relacionamento entre as comunalidades entre objetos ocorrida em uma analogia, onde estas acabam por assumir características de analogias quando compartilham informações relacionais primárias. Devido a isso, as analogias podem ser consideradas como uma classe mais rigorosa de metáforas. Neste sentido Bateson (1967) trás uma contribuição importante ao afirmar que as metáforas rigorosas se apresentam como técnicas importadas dos processos dedutivos e formais da lógica matemática, adequadas para a análise de processos de origem cibernética - como os sistemas complexos.

Uma vez que as analogias são uma classe mais rigorosa de metáforas estas podem, então, ser utilizadas como elos de ligação entre o intuitivo e o racional, pois fazem parte da evidência fenomenológica e, também, das matérias primas para o processo lógico dedutivo. O processo analógico também se mostra capaz de organizar e classificar a auto-evidência, a partir de um conjunto icônico comum que pode auxiliar a discriminar os juízos que se tratam de uma síntese da totalidade, daqueles que não passam de mera mitificação. Destarte, a adoção deste método híbrido, capaz de acomodar tanto a evidência da intuição como a classificação e organização do conhecimento, supri grande parte das necessidades impostas pela perspectiva da complexidade. Em decorrência disso, esta postura investigativa foi a adotada no decorrer do presente esforço de pesquisa.

\subsection{MÉTODO DE COLETA DE EVIDÊNCIAS}

Seguindo o raciocínio anterior, a coleta de evidências deste esforço de pesquisa se deu em duas fases distintas. Em um primeiro momento foi utilizado o método 
fenomenológico de redução eidética para, a partir da intuição, elaborar um esquema sintético da essência primeira dos aspectos internos e externos do problema estratégico. Em uma segunda etapa, foi feita pesquisa bibliográfica em busca de fenômenos que pudessem ser usados como entidades análogas à evidência encontrada a partir do método fenomenológico. Os procedimentos detalhados de cada fase deste processo são tratados nos parágrafos que se seguem.

\section{Fase 1: Captura da essência do fenômeno.}

Esta etapa foi desenvolvido por meio do processo de redução eidética, proposta por Husserl (2001). A redução eidética consiste em um processo no qual se remove as relações do fenômeno com o meio externo, até o momento em que a remoção de quaisquer das relações restantes faça com que o fenômeno deixe de ser reconhecido como tal. Sob a concepção da fenomenologia de Husserl este é o momento em que o fenômeno se revela como uma potencialidade pura que, em última análise, é a generalidade essencial que Ihe permite ser reconhecido como tal (HUSSERL, 2001).

Tendo por base as condições sociais, ambientais e econômicas, expostas na introdução do presente esforço de pesquisa, a evidência primeira dos aspectos internos e externos do problema estratégico que surge a partir do esforço de redução eidética, se manifesta de acordo com o esboço mostrado na figura 14. Nele, os seres humanos estão representados pelos hexágonos em preto, cujas relações - dadas na mesma cor - se dão por meio da comunicação e de trocas materiais. Os círculos azuis representam a estrutura física das organizações, que se relacionam diretamente com os humanos que as compõem representados dentro dos respectivos círculos fronteiriços. Estas organizações - formadas pelas relações entre humanos e estrutura - se relacionam entre si e com outros humanos e entidades análogas, formando o ambiente econômico. Já as setas vermelhas correspondem às trocas realizadas entre a organização, os seres humanos e o sistema planetário - que contempla energia, elementos orgânicos e inorgânicos. 


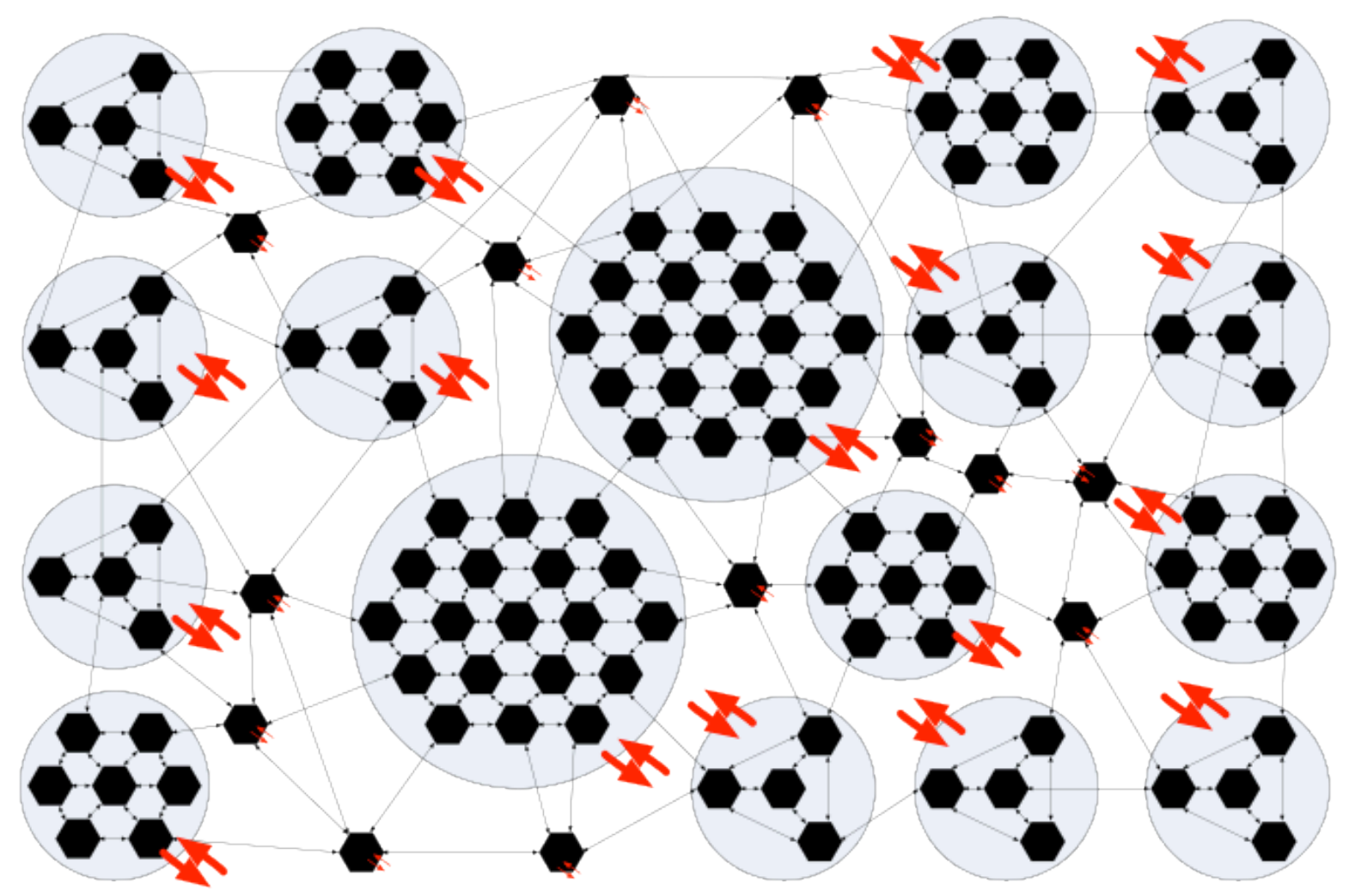

Figura 14 - Esboço da essência primeira do problema estratégico.

Fonte: Elaborada pelo autor

O esboço ilustrado na figura 14 se mostra como evidência primeira dos aspectos internos e externos do problema estratégico, pois a remoção de qualquer das relações indicadas, torna o sistema ilustrado incompatível com os aspectos essenciais das relações internas e externas às organizações. Se a organização e os humanos deixam de se relacionar com o sistema planetário, o sistema como conhecemos deixa de existir, pois não há mais transito de matéria e energia entre o sistema planetário, os indivíduos e as organizações. Esta dinâmica se mostra evidente e necessária para manutenção das organizações contemporâneas, assim como estas são. Se os humanos também deixam de se relacionar entre si e com a estrutura física da organização, tem-se espaço o mesmo tipo de desintegração, já que sem estas trocas as organizações e, até mesmo, o sistema econômico, deixam ser percebidos tal como o são. Portanto, qualquer das relações propostas é crucial para que o sistema que compõe o problema estratégico exista da forma com a qual ele é dado à consciência. Desse modo a figura 14 se mostra como a evidência primeira a ser submetida ao escrutínio e ao esforço organizador de uma etapa analítica.

É importante ressaltar que as discussões sobre as abordagens contemporâneas de gestão foram desenvolvidas posteriormente à confecção desta descrição da essência 
primeira do problema estratégico. Esta tática de estudo se baseou nos preceitos da fenomenologia, para a qual os estoques de conteúdo da consciência podem agir como ruído para a percepção acerca dos fenômenos observados. Por meio desta postura, esperava-se minimizar os impactos de concepções prévias sobre os conteúdos da consciência, nos quais se basearia a construção desta essência primeira.

\section{Fase 2: Pesquisa bibliográfica.}

O método de pesquisa adotado neste procedimento de pesquisa, requer meios estruturados para viabilizar a classificação e a reflexão crítica acerca da evidência encontrada, por meio de estruturas organizacionais análogas. Destarte era preciso ter uma plataforma teórica estabelecida que permitisse reconhecer concepções análogas para representar o problema. Para tal foi realizada uma pesquisa bibliográfica, baseada na evidência primeira encontrada por meio da redução eidética do problema estratégico e no levantamento bibliográfico efetuado no início deste esforço de pesquisa.

Neste ponto vale ressaltar a diferença entre a revisão bibliográfica e a pesquisa bibliográfica. Em um trabalho científico a bibliografia pode atuar tanto como fonte quanto como simples revisão da literatura, dependendo da abordagem utilizada (CERVO; BERVIAN, 2002). Neste sentido Lima e Mioto (2007) afirmam que:

[...] a revisão de literatura é apenas um pré-requisito para a realização de toda e qualquer pesquisa, ao passo que a pesquisa bibliográfica implica em um conjunto ordenado de procedimentos de busca por soluções, atento ao objeto de estudo, e que, por isso, não pode ser aleatório (LIMA; MIOTO, 2007).

Destarte, esta pesquisa abrangeu ambas as abordagens. Inicialmente foi feita uma revisão da literatura, estruturada por meio de buscas por autores consagrados da área da estratégia e obras acerca dos novos paradigmas científicos que se mostrassem acessíveis ao leitor da área de ciências sociais aplicadas. As buscas iniciais foram realizadas por meio das bases de dados PROQUEST, JSTOR e ISI Web of Knowledge e da biblioteca central do campus da USP de Ribeirão Preto. Este levantamento inicial foi desenvolvido não para atuar como fonte e sim para permitir o reconhecimento do problema e uma maior compreensão acerca da complexidade, da nova ciência e das perspectivas contemporâneas acerca da estratégia. Esta etapa do desenvolvimento do trabalho também destacou autores e conceitos 
representativos para o problema que, posteriormente, foram utilizados de base para formular a coleta de dados realizada por meio da pesquisa bibliográfica.

Após concluído o levantamento bibliográfico e a construção da evidência primeira do problema estratégico, foram seguidas as recomendações de Cooper e Schindler (2003) que sugerem que se estabeleça previamente as declarações de busca dos conteúdos, para serem usados como análogos na complementação e na descrição da evidência primeira. No entanto, se manteve certa liberdade para a realização de buscas derivadas das leituras obtidas pelos procedimentos iniciais, já que, conforme lembram Lima e Mioto (2007), as declarações de buscas não devem se tornar um engessamento para a estrutura da pesquisa, uma vez que a própria pesquisa bibliográfica tem um caráter dinâmico, no qual a construção de uma nova visão, proporcionada pela leitura, pode levar a uma nova necessidade de informações acerca da problemática estudada.

Os principais autores e conceitos tratados na etapa analógica foram levantados por meio de obras abordadas durante a etapa de levantamento bibliográfico. Neste sentido se destacaram os livros The turning point de Fritjof Capra e Strategy safari de Henry Mintzberg, Bruce Ahlstrand e Joseph Lampel. A primeira se constitui em uma obra que descreve a transição do antigo para o novo paradigma das ciências, por meio de exemplos e exposições acerca dos principais estágios desta revolução e dos aspectos gerais de diversos dos fenômenos que desencadearam estes eventos. Já a segunda é uma importante obra de compilação da área de estratégia, que descreve um bem concebido panorama acerca do processo estratégico, estruturado sobre dez escolas de pensamento e cinco definições distintas do termo estratégia.

A obra de Mintzberg, Alhstrand e Lampel (1998) recebeu especial atenção no desenvolvimento deste trabalho, com dois capítulos concentrados em duas definições e descrições. Isso porque, o esforço realizado por estes autores contempla a dimensão do problema estratégico que se refere ao seu processo. Sua obra, além de ser dotada de excepcional qualidade, é, portanto, complementar aos objetivos deste esforço de pesquisa, já que este busca descrever os aspectos internos e externos suscitados pela situação e, por consequência, as variáveis a eles relacionadas.

Na natureza, seja em uma cadeia alimentar, seja na cooperação entre células e organismos, se observa um padrão em rede, onde se vê a formação de uma teia interligada com subsistemas em rede compondo sistemas maiores (CAPRA, 2006). Uma vez que 
descrição da essência primeira do problema estratégico - mostrada na figura 14 -, se apresenta como um conjunto de interação em formato de rede, fica evidente que esta dinâmica relacional apresenta uma forte ligação icônica com o problema da vida. Este tipo de abordagem também possui forte afinidade com o novo espírito científico e se mostra entre os mais engajados com os ideais da complexidade, o que o torna apropriado para elaboração da síntese final deste objeto de pesquisa, a partir de um processo analógico.

Com a evolução do quadro do trabalho, três assuntos relacionados ao problema da auto-organização e da vida se destacaram como possíveis análogos a partes da evidência primeira, esboçada na figura 14. São elas: as características dos tecnosistemas desenvolvidos pelo homem, propostas inicialmente por diversos autores da cibernética, as características das máquinas autônomas, propostas pelas teorias acerca dos sistemas autorreferentes de Humberto R. Maturana e Francisco J. Varela e as concepções acerca dos sistemas simbióticos, cujos trabalhos mais importantes são atribuídos a Lynn Margulis e James Lovelock.

O foco do presente esforço de pesquisa foi, então, direcionado para as obras chave de cada uma destas teorias que, na maioria dos casos, remetem aos pioneiros de cada uma destas concepções. Porém, em alguns casos a teoria apresentou avanços em múltiplos passos, ou foi compilada de forma competente por autores posteriores aos pioneiros. Muitas destas obras de compilação acabaram por se tornar referências em suas respectivas áreas e, nestes casos, optou-se por abordar tais compilações, em detrimento das obras dos precursores.

As características das máquinas alopoiéticas possuem fontes com possibilidades variadas. Desta forma foram abordadas pesquisas em bases de dados e em livros texto, por meio dos Thesaurus "Cybernetics machines" e "Principles of Cybernetics". A triagem inicial dos resultados - cujo número inicial pode ser vistos na tabela 2 - foi feita por meio do título, visando excluir aqueles artigos que se constituíam em aplicações ou assuntos de pouco interesse para descrever as máquinas do tipo alopoiéticas.

Em uma segunda etapa foram analisados os resumos das obras restantes. Os artigos aprovados neste estágio foram incorporados aos selecionados para leituras. Também foram pesquisados livros sobre o tema por meio das bases do Dedalus e Google Books. Dentre as obras sobre o assunto, se destacaram a obra Introdução à cibernética de W. Ross Ashby, pela excelente compilação e por se tratar de uma das obras consagradas acerca da auto- 
regulação, e a obra Teoria geral dos sistemas de Ludwig von Bertalanffy, pela pioneira abordagem orgânica das perspectivas cibernéticas.

As tratativas acerca das máquinas autopoiéticas e dos sistemas simbióticos ainda são recentes e seu escopo de aplicações ainda rende inúmeras controvérsias. Há discordância acerca dos limites até onde tais concepções podem ser aplicadas em seu formato original. De modo a evitar o uso destas concepções de forma distorcida em relação às suas proposições, o trabalho se concentrou nas obras elaboradas pelos pioneiros e pelos autores de destaque em cada uma das área, já citados anteriormente. Além disso, foi feita uma busca por artigos, por meio dos termos Gaia, Symbiotic Evolution e Autopoiesis. O método de triagem dos resultados - cujos números podem ser vistos na tabela 2 - foi o mesmo utilizado para os artigos referentes às máquinas alopoiéticas.

\begin{tabular}{lccc}
\hline \multirow{2}{*}{ Palavras Chave } & \multicolumn{3}{c}{ Bases de Dados } \\
\cline { 2 - 4 } & ISI Web of Knowledge & PROQUEST & JSTOR \\
\hline Cybernetics machines & 82 & 38 & 75 \\
\hline Principles of Cybernetics & 2 & 954 & 3204 \\
\hline Gaia & 1364 & 23236 & 3013 \\
\hline Symbiotic Evolution & 1901 & 78 & 377 \\
\hline Autopoiesis & 361 & 1361 & 14 \\
\hline
\end{tabular}

Tabela 2 - Número de resultados retornados nas pesquisas realizadas nas bases de dados Fonte: Elaborada pelo autor

Dentro do aspecto dinâmico da pesquisa teórica, é importante ressaltar que as pesquisas referentes às máquinas autopoiéticas despertaram a necessidade de pesquisas em mais uma área, importante para a compreensão acerca da dinâmica da mesma: a teoria dos sistemas dissipativos, elaborada por llya Prigogine. A teoria dos sistemas dissipativos é a base lógica e matemática que sustenta a ideia de auto-organização por trás das máquinas autopoiéticas e uma série de outros sistemas similares. Os estudos desta teoria se concentraram nos trabalhos de seu concebedor, o químico belga llya Prigogine

Além dos estudos colhidos por meio da pesquisa bibliográfica, muitos dos trabalhos obtidos na etapa de levantamento bibliográfico também foram incorporados na etapa analógica. Somando-se a etapa de levantamento bibliográfico e de pesquisa bibliográfica, foram angariados e avaliados, através de leitura diagonal, 139 livros e 339 artigos. Seguindo as recomendações de Lima e Mioto (2007) e Goldenberg (2007), houve uma preocupação com a organização e o fichamento do conteúdo que seria aproveitado. Dentre o material 
coletado e analisado, 78 livros e 82 artigos continham contribuições e compilações de conteúdo que se mostraram relevantes aos objetivos do estudo. Estes foram relidos e completa ou parcialmente fichados para consulta posterior em um documento dividido por assunto, gerenciado pelo software Endnote X3.

\subsection{PROCEDIMENTO DE ANÁLISE}

Conforme citado anteriormente, este trabalho se utilizou de um procedimento de inferência baseado em lógica dedutiva, por meio de transposições por analogias. "A analogia é um raciocínio que conclui de certas semelhanças observadas, outras semelhanças ainda não observadas" (PARRA FILHO; SANTOS, 2002, p. 82). Em outras palavras, os métodos baseados em analogias visam "[...] investigar coisas ou fatos e explicá-los segundo suas semelhanças e suas diferenças." (FACHIN, 2001, p. 37). Segundo Parra Filho e Santos (2002) as analogias levam a hipóteses, ou conclusões prováveis, portanto não podem ser tratadas como conclusões com elevado grau de certeza. Destarte, as conclusões de uma analogia se limitam aos análogos, à experiência e às consequências da conclusão. A transformação de uma analogia em uma teoria com maior grau de certeza depende, em última instância, de demonstrações, onde a semelhança entre os análogos se mostram bastante fortes.

Nagel (1979) divide as analogias em dois 2 tipos, as substantivas e as formais. As substantivas partem do pressuposto que um determinado sistema possui certas propriedades conhecidas e estas servem de modelo icônico para um novo sistema, não incorrendo, necessariamente, em uma transposição conceitual do sistema conhecido para o novo sistema. Este foi o tipo de analogia usada pelo físico James Clerk Maxwell, ao elaborar as leis do magnetismo. Já nas analogias formais o pesquisador se basearia em um conjunto abstrato e correlato de conceitos matemáticos, que nutrem similaridades entre si. Estes conceitos podem compor a descrição de um segundo fenômeno a partir de uma estrutura 
abstrata originária e correlata. Em resumo, pode-se dizer que na analogia substantiva existe uma similaridade icônica, enquanto na analogia formal existe uma similaridade conceitual entre os elementos estudados (NAGEL, 1979).

Neste ponto vale ressaltar que a complexidade "[...] não se dedica a descobrir analogias fenomênicas, mas a encontrar os princípios comuns organizacionais, os princípios de evolução destes princípios, os caracteres de sua diversificação." (MORIN, 2007c, p. 28) Conforme tratado no capítulo anterior, os estudos acerca do problema da vida se mostraram promissores para servirem como alicerces análogos à complexidade da descrição da essência primeira do problema estratégico, principalmente para estabelecer um conjunto de relações icônicas acerca de princípios organizacionais.

Devido a esta compatibilidade, o presente esforço de pesquisa se utilizou de analogias substantivas entre os sistemas vivos e a essência primeira do problema estratégico. Entretanto, Aktouf (1996) ressalta que tal tipo de analogia entre as áreas de biologia e da gestão, foi amplamente utilizado com o objetivo de legitimar comportamentos agressivos e dominadores, por parte dos detentores do controle, e até mesmo para justificar as desigualdades sociais inerentes ao capitalismo contemporâneo. O autor propôs, então, que para evitar os abusos das transposições, baseadas no comportamento animal e nas distorções do darwinismo, é preciso levar em conta a interdependência entre o indivíduo e os grupos que os cercam.

A interdependência, indicada por Aktouf (1996), já se mostrava presente na ilustração da essência primeira do problema estratégico, através dos laços de realimentação criados pela estrutura em teia. Para se evitar incorrer no mesmo tipo de desvio indicado pelo autor, este esforço de pesquisa seguiu rigidamente os princípios sistêmicos - de ir do todo as partes e das partes ao todo. A síntese da essência primeira do problema estratégico foi desmembrada em seus subsistemas e estes foram analisados por meio analogias entre as dinâmicas dos mesmos e as dinâmicas já conhecidas nos estudos da ciência da vida. Na sequência a totalidade sistêmica foi restabelecida, por meio do acoplamento de seus subsistemas, de forma que nenhuma das relações encontradas fosse perdida ou subtraída da descrição do fenômeno. Desse modo, foi possível garantir que nenhuma relação, apontada na essência primeira, pudesse ser destruída por conveniência no momento da construção de alguma das etapas analógicas. 


\subsection{ORGANIZAÇÃO DOS RESULTADOS}

O processo de reintegração, ocorrido na etapa analógica contribuiu de forma significativa para a organização dos resultados deste trabalho, principalmente a construção de uma concepção simplificada do problema estratégico. Mas por conta do ideal complexo, o presente esforço de pesquisa foi desenvolvido por meio de uma concepção de pesquisa em rede, onde uma leitura levava a outra, não necessariamente na mesma disciplina.

Ao final, o entrelaçamento e a multidisciplinaridade levaram à construção de "esqueletos" desordenados de conceitos a serem relacionados. O esforço para tornar estes conteúdos coerentes se deu por meio de um método interativo, no qual o "esqueleto" do trabalho foi sucessivamente tratado e organizado por meio de leituras sequenciais, até que o texto chegasse ao formato apresentado. A dinâmica deste processo encontra-se ilustrada na figura 15.

Etapa N

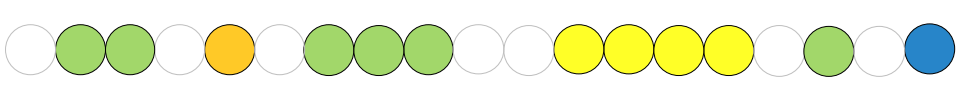

Etapa $\mathrm{N}+1$

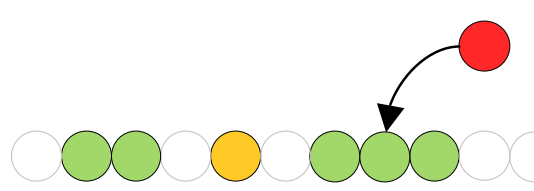

Etapa $\mathrm{N}+2$

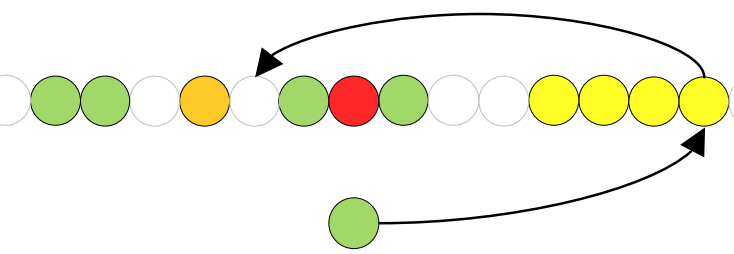

Resultado

Figura 15 - Dinâmica das interações para organizar a expressão dos conteúdos. Fonte: Elaborada pelo autor 


\subsection{SOBRE LIMITAÇÕES}

Devido a postura fenomenológica, adotada pelo presente trabalho, se fazem necessárias algumas considerações a respeito das escolhas e das limitações da mesma. A primeira ressalva importante, se deve à impossibilidade de separação entre sujeito e objeto. Tendo por base este pilar da fenomenologia, este esforço de pesquisa assume que, tanto os conteúdos pesquisados, como os conteúdos deles derivados, tratam-se de uma verdade momentânea, baseada em um constructo da realidade estruturado sob as perspectivas do autor, diante da realidade histórica da sociedade atual.

Diante disso, o presente esforço de pesquisa pretende delimitar o problema por meio de uma perspectiva que se enquadra em uma percepção temporária, baseada em fenômenos contemporâneos. Uma vez que os cenários históricos assumem uma condição transitória, é importante ressaltar que este esforço oferece uma inegável dificuldade de reprodução e não pode assumir um caráter de descrição final ou absoluta para o problema estratégico.

Mas é importante ressaltar que, mesmo diante destas dificuldades impostas pela abordagem fenomenológica, a importância de trabalhos concebidos a partir da ciência das possibilidades puras não pode ser negligenciada. Conforme lembra Husserl (2001), as próprias delimitações realizadas pela ciência tradicional se tratam, na verdade, de reduções originalmente eidéticas que são convertidas posteriormente em atividades empíricas. "Assim a ciência das possibilidades puras precede em si aquelas das realidades e as torna possíveis como ciência." (HUSSERL, 2001, p. 88) Isso destaca que as descrições oriundas da intuição são, na verdade, as hipóteses que fundamentam e precedem as descrições do tipo empíricas. Portanto, aquelas são subsídios para estas e não substitutas.

Neste aspecto Bateson (1967) ressalta que quando se estuda um ambiente determinado pelo contexto, a distinção entre os passos dedutivos e indutivos do processo de explicação se faz importante. Em decorrência disso, o presente esforço de pesquisa se concentrou em construir uma hipótese, baseada em uma postura lógica dedutiva, baseada nas possibilidades puras. Portanto ele abre espaço para novos estudos acerca do tema, 
inclusive de origem empírica. Assim, é até mesmo encorajado que os resultados deste esforço venham a ser testados, complementados e, até mesmo, contestados e substituídos por novas hipóteses e teorias acerca do problema.

Destarte, o presente esforço de pesquisa não visa substituir, ou negar os esforços anteriores, que tanto têm contribuído para a evolução das organizações contemporâneas, tampouco se colocar acima dos métodos empíricos. Pelo contrário, ele parte de uma postura conciliadora, cujo objetivo é encontrar um eixo comum que permita, não só a unificação destes esforços, como também a ascensão de novas ideias, posturas e investigações acerca do problema estratégico.

Por fim, uma última dificuldade importante deste estudo surgiu devido ao caráter multidisciplinar da pesquisa e às múltiplas origens disponíveis para busca de informações. Neste cenário o tempo se tornou um significativo fator limitador para que uma pesquisa que abarcasse todos os aspectos do fenômeno, pudesse ser exequível em um espaço temporal limitado. Abranger todo o conteúdo acerca da complexidade e transportá-lo para o ambiente da estratégico, é um esforço para muitas outras esferas possíveis de pesquisa. A ciência da complexidade também se trata de uma ciência em estágio embrionário, com muitos fenômenos e interações ainda por descobrir e investigar. De certo modo, este esforço de pesquisa consiste, então, em um primeiro passo, baseado nos primeiros passos de novas perspectivas emergentes de investigação. 



\section{A DINÂMICA DOS ASPECTOS INTERNOS E EXTERNOS DA ORGANIZAÇÃO}

Os estudos dos fenômenos a partir do reconhecimento dos mesmos como análogos às máquinas é algo que permeia o pensamento científico desde seus primórdios, quando Descartes comparou o universo ao relógio, que tanto o encantara (CAPRA, 1983). Contudo, Ashby (1970) ressalta que na perspectiva da cibernética - que permeia todo o conhecimento complexo - as máquinas são tratadas como todo e qualquer dispositivo dinâmico, cuja operação apresenta dois ou mais estágios distinguíveis entre si. Portanto, todos os sistemas dinâmicos estudados pela complexidade, independente de sua natureza, são tipos particulares de máquinas (ASHBY, 1970).

Em decorrência deste cenário, Pierce (1980) afirma que os estudos acerca dos sistemas e da complexidade seriam, então, áreas especiais da ciência da cibernética que, para o autor, abrange desde o que há de mais novo em termos de teoria da informação até as máquinas autônomas e complexas, como os organismos vivos. Portanto a Cibernética evoluiu, por meio destas concepções da nova biologia, para a complexidade.

Tal situação expande o alcance dos ideais mecanicistas da cibernética, até mesmo para os estudos acerca da dinâmica dos sistemas vivos, propostos por autores de grande impacto na nova ciência, como Varela (1979), Watson e Lovelock (1983), Maturana e Varela (1988, 1997), Margulis (1998) e Lovelock (2000). Os trabalhos destes autores se baseiam em princípios cibernéticos que mostram a vida como um tipo muito especial de máquina, com particularidades dinâmicas que às distinguem das máquinas causais cartesianas. Deste modo, a diferença entre o vivo e o não vivo não se encontra em seus componentes e sim nas regras de funcionamento que os definem como unidades distintas da concepção de máquina proposta por Descartes.

Enquanto o ideal de ciência cartesiana é reducionista e se preocupa com os componentes de uma máquina, a complexidade também se preocupa com as relações entre seus constituintes e a inter-relação da própria máquina com o componentes externos do sistema - ver capítulo 2.5. A complexidade se trata, portanto, de uma abordagem cuja base é mecanicista mas contempla certas particularidades onde mecanismos característicos, 
regidos por relações de causa e efeito autorreferentes e não-lineares, são capazes de sintetizar as regras de funcionamento de fenômenos que vão desde a essência dinâmica do organismo mais simples, até o complexo ecossistema planetário, inclusive os sócios-sistemas compostos pelo homem. Destarte, a diferença essencial entre o pensamento cartesiano e a perspectiva da complexidade, não reside no embate entre mecanicismo e organicismo, uma vez que o próprio organismo se trata de um tipo particular de máquina, que se configura como viva.

A discrepância entre o paradigma cartesiano e a complexidade reside, portanto, no jogo dialógico entre o reducionismo e o holismo, certezas e incertezas, linearidade e nãolinearidade. Assim, o organismo pode ser considerado como uma máquina "[...] no sentido em que este termo significa totalidade organizada, mas de um tipo diferente do das máquinas artificiais, a alternativa ao reducionismo não está num princípio vital, mas numa realidade organizacional viva." (MORIN, 2007c, p. 29) Então, pode-se dizer que o tipo de tratamento fenomênico que trata as entidades sistêmicas como máquinas, não é algo exclusivo do pensamento cartesiano e sim uma abordagem fundamental, até mesmo para os novos paradigmas científicos.

Portanto, a ciência da complexidade não nega os ideais mecanicistas do pensamento cartesiano, ela amplia tais concepções para um novo patamar qualitativo. Sob esta concepção, os sistemas vivos como as sociedades, os ecossistemas e os próprios organismos, podem ser entendidos como máquinas dotadas de particularidades, cuja dinâmica dependeria, em última análise, de sua relação com outras máquinas e, por consequência, da própria dinâmica da rede que os integra. Destarte, a descrição de um sistema análogo aos sistemas vivos, como a essência primeira do problema estratégico - ver capítulo 4.1 -, passa pela compreensão do mesmo como uma grande máquina que contempla particularidades essenciais das dinâmicas de outros tipos de máquinas, muitas delas já estudadas pela nova ciência. 
De acordo com Pierce (1980) a Cibernética tem como objetivo compreender a dinâmica que leva ao equilíbrio, em máquinas complexas e autogovernadas. Isso remete à concepção de governança em sistemas ricamente interligados e perturbados como aqueles com os quais lida a estratégia - ver capítulo 3.1. Já que a Cibernética se dedica a esclarecer problemas similares aos tratados pela disciplina da estratégia, os princípios e descrições da mesma se revelam com grande potencial para auxiliar na compreensão dos aspectos internos e externos da organização.

O problema básico da Cibernética pode ser exemplificado por meio de uma de suas primeiras aplicações: a construção de dispositivos de artilharia autônomos. Uma máquina deste tipo precisa agir com base em um conjunto de informações coletadas do ambiente, para antecipar o movimento do alvo e ajustar seu canhão para a posição prevista, o que nutre grande similaridade com os objetivos das escolas prescritivas de estratégia. Os desafios para a construção de tal dispositivo vão, desde determinar precisamente qual informação é útil para que o sistema possa prever as mudanças de rota do alvo, até o método com o qual estas informações são processadas pelo sistema.

Neste tipo de rastreamento os métodos de previsão lineares se mostram eficientes para prever o movimento de objetos que se movem por meio de rotas mais simples, como uma linha reta. Em casos como este, a precisão do dispositivo é maior tanto quanto forem maiores as quantidades de dados históricos disponíveis para avaliação. Contudo, no caso de rotas mais complexas, como um ziguezague, os dados mais antigos podem atrapalhar significativamente a previsão da rota do objeto (PIERCE, 1980). Neste cenário, apenas os dados mais recentes teriam alguma contribuição para prever a trajetória de um objeto, o que os tornariam mais importantes do que aqueles mais distantes no tempo.

A figura 16 demonstra esta diferença. Nela o caminho percorrido pelos alvos é dado pelas linhas pontilhadas. A trajetória prevista por meio de um modelo baseado em um grande volume de dados históricos é dada pela linha contínua na situação $A$, enquanto e a rota prevista por um modelo baseado em dados recentes é dada pelas linhas contínuas ilustradas na situação B.

Para que uma máquina de artilharia autônoma, possa acompanhar mudanças e se adequar a elas com maior eficiência, ela teria que se comportar de maneira dinâmica. Precisaria, no mínimo, identificar variações nos comportamentos dos dados e, nestas condições, atribuir pesos maiores para os dados mais recentes do que para os dados mais 
antigos. Nestas condições, Pierce (1980) ressalta que mesmo este tipo de modelo, dado a partir de uma regra que define quando considerar entre dois preditores lineares, onde um leva em consideração medições antigas e outro predições recentes, se comporta de maneira não-linear. A não-linearidade encontrada neste exemplo é uma das principais características dos sistemas cibernéticos.
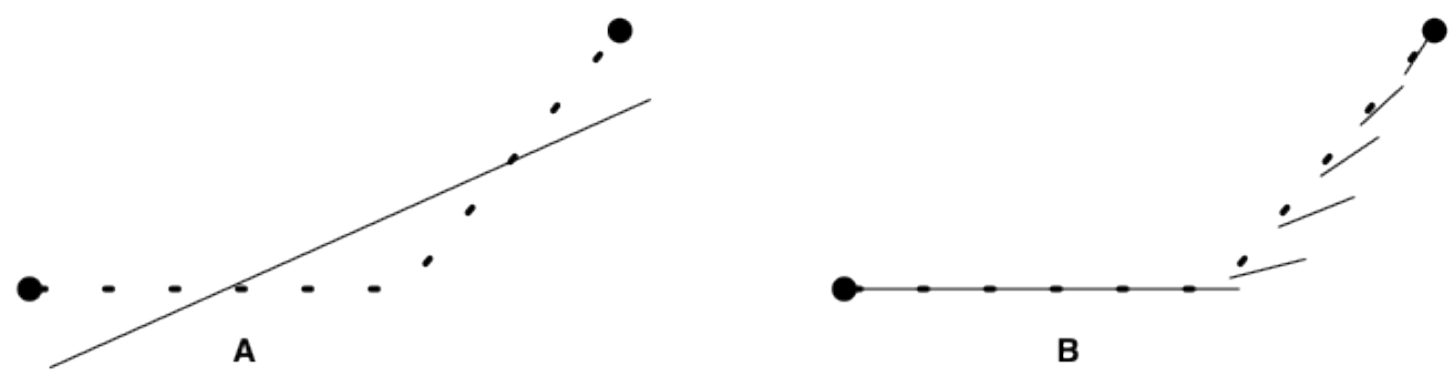

B

Figura 16 - Rotas previstas para uma abordagemcom enfoque em pesos iguais (A) e para uma abordade com enfoque em pesos maiores para os dados mais recentes (B).

Adaptado de: Pierce (1980, p. 212)

Este exemplo também ilustra o aspecto fundamental de qualquer máquina Cibernética. Assim como no caso do timoneiro, o movimento do canhão implica em um sistema que contempla entradas, saídas, um processador de informações e um laço de realimentação, provocado pela própria mudança na posição do sistema - ver figura 17. 0 quadro 7 descreve detalhadamente cada um dos componentes deste sistema básico.

Entrada ou input: é constituída por um ou mais destes três insumos: Matéria, energia e informação; Informação: é tudo o que possibilita reduzir a incerteza a respeito de algo.

Saída ou output: é o resultado do funcionamento do sistema, devolvido ao meio ambiente. Pode ser composta por energia, matéria e/ou informação.

Ambiente: input e output correspondem às interações entre ambiente e o sistema; assim ambiente e sistema são interdependentes.

Processamento: é o mecanismo de conversão do input em output, descreve a ação do sistema. Este mecanismo nem sempre é conhecido.

Retroalimentação ou feedback: corresponde ao uso que o sistema faz, sob forma de input, do output ou de parcela do mesmo. É por meio do feedback que o sistema pode verificar se os resultados estão ou não em conformidade com o previsto. 


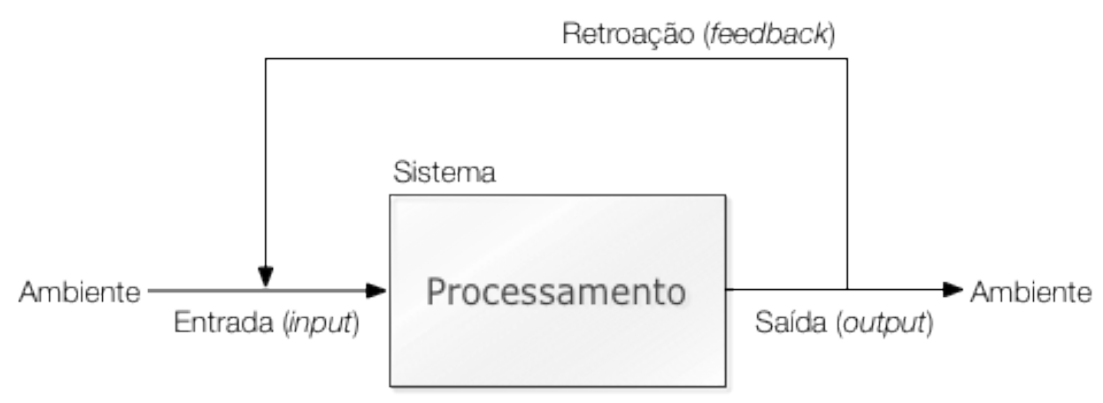

Figura 17 - Modelo básico para a cibernética e a teoria geral dos sistemas Fonte: Bauer (1999, p. 47)

A frequente ocorrência de laços de realimentação (feedback) é uma das mais importantes propriedades dos sistemas não-lineares (CAPRA, 2006).

Matematicamente, um laço de realimentação corresponde a um tipo especial de processo não-linear conhecido como iteração (palavra que em latim significa "repetição"), na qual uma função opera repetidamente sobre si mesma. Por exemplo, se a função consiste em multiplicar a variável $x$ por $3-$ isto é, $f(x)=3 x-a$ iteração consiste em multiplicações repetidas. (CAPRA, 2006, p. 107)

Os passos oriundos de uma iteração são chamados de mapeamentos e são representados por um conjunto de transições de estado do tipo $x \rightarrow y$ (ASHBY, 1970; CAPRA, 2006). O mapeamento dos estados do exemplo dado por Capra (2006) poderia ser, então, representado por $x \rightarrow f(x)$, onde $f(x)=3 x$. Nesta iteração o resultado seria uma dinâmica não-linear, similar à ilustrada no capítulo 2.5, cujas transições se encontram no quadro 8.

$$
\begin{gathered}
x \rightarrow 3 x \\
3 x \rightarrow 9 x \\
9 x \rightarrow 27 x
\end{gathered}
$$

etc.

Quadro 8 - Mapeamento dos estados dados por transições de estado $x \rightarrow f(x)$ onde $f(x)=3 x$ Fonte: Capra (CAPRA, 2006, p. 108)

Os laços de realimentação podem assumir tanto um papel de anular os processos de transformação do sistema - feedback negativo -, como um papel de auto-reforço do comportamento de mudança - feedback positivo (CAPRA, 2006). O exemplo do timoneiro ver capítulo 2.5 - ilustra uma situação de feedback negativo, onde o piloto do barco atua como um servomecanismo que age de forma a anular os desvios de rota provocados pelo 
ambiente. Já os comportamentos de pânico em bolsas de valores, se desenvolvem por meio de feedback positivo, onde a saída de um grupo de investidores do mercado pode desencadear um processo de retiradas sucessivas que se tornam cada vez maiores e mais abrangentes.

O conceito de laços de realimentação é a essência por trás da busca pelo equilíbrio em máquinas auto-governadas, que se dá a partir da ação de um dispositivo regulador, atuando por meio de feedback negativo (PIERCE, 1980; BAUER, 1999; CAPRA, 2006; BERTALANFFY, 2009). Apesar de fundamental para os dispositivos de controle, os laços de realimentação apresentam grandes desafios para a governança de qualquer tipo de sistema.

Nos sistemas lineares, pequenas mudanças produzem pequenos efeitos, e grandes efeitos se devem a grandes mudanças ou a uma soma de muitas pequenas mudanças. Em sistemas não-lineares, ao contrário, pequenas mudanças podem ter efeitos dramáticos, pois podem ser amplificadas repetidamente por meio de realimentação de auto-reforço. Esses processos de realimentação não-lineares constituem a base das instabilidades e da súbita emergência de novas formas de ordem, tão típicas da auto-organização. (CAPRA, 2006, p. 107)

Deste modo, os feedbacks, sejam eles positivos ou negativos, podem atingir magnitudes tais que podem tornar o sistema instável. Mesmo o feedback negativo, que normalmente tem por objetivo a regulação do sistema, "[...] em alguns casos pode fazer o comportamento divergir significativamente da meta desejada." ${ }^{\prime 66}$ (PIERCE, 1980, p. 227) Assim, o processamento de dados em um sistema com dinâmica não-linear precisa de cuidados para que as ações do dispositivo regulador não desencadeiem alterações de grande magnitude no sistema como um todo. Para enfrentar tal dificuldade, Pierce (1980) sugere que os sistemas de controle precisam incorporar algum tipo de amortecimento no feedback, para que ele seja intenso apenas quando se faz necessário e seja mais leve quando a leitura se aproxima do valor esperado.

Diante das possibilidades de mudanças a que se submetem, os dispositivos de controle da Cibernética também se encontram submetidos a uma lei, denominada lei da variedade necessária. De acordo com esta lei, o aumento da variedade de opções de resposta de um determinado agente, reduz a variedade de resultados possíveis para uma interação (ASHBY, 1970).

\footnotetext{
${ }^{66}$ Do inglês: "[...] can sometimes be to make the behavior diverge widely from desired goal."
} 
A lei da variedade necessária nutre uma forte relação com uma segunda lei da cibernética, a lei do conhecimento necessário. Esta última afirma que um sistema de controle precisa conhecer as variedades de ação que devem ser acionadas para lidar com cada tipo de perturbação. Portanto, ao consolidar estas duas importantes leis da Cibernética, conclui-se que a capacidade de ação, por si só, não garante que o dispositivo de controle saiba quando acionar uma determinada ação para lidar com um determinado problema. Neste caso, há de se ressaltar que por melhor que seja o conhecimento de um sistema, este ainda terá um número finito de alternativas e, portanto, ele ainda estará sujeito a ser surpreendido por possibilidades imprevistas. (HEYLIGHEN, 1992).

O "[...] padrão, ou previsibilidade de eventos em particular a partir de um amplo agregado de eventos é chamado de "redundância"."67 (BATESON, 1967, p. 31, tradução nossa) Destarte, garantir a redundância em um sistema significa garantir variedade e capacidade de uso da variedade. Por consequência, a redundância possui estreita relação com a capacidade do sistema de prever falhas e perturbações. Neste sentido, Bateson (1967) destaca que para maximizar a redundância é preciso fornecer subsídios para que o sistema reconheça brechas nas informações e consiga preencher, por meio de indução estatística, tais lacunas. Para isso, é preciso que o sistema contenha regras de redundância que lhe permitam identificar a informação enviada pelo transmissor, mesmo que esta venha incompleta.

Além do aspecto da não-linearidade, o modelo ilustrado na figura 17 mostra que as máquinas estudadas pela Cibernética diferem significativamente das máquinas determinadas, representadas pelo relógio de Descartes e pelas máquinas estudadas pela termodinâmica. Estas últimas apresentam trocas externas nulas, enquanto as primeiras envolvem ao menos uma entrada que pode ser uma fonte energética, material organizacional ou informacional externa (ASHBY, 1970; MORIN, 2007c). Em uma máquina aberta:

o estado estável mantém-se à distância do verdadeiro equilíbrio e portanto é capaz de produzir trabalho, como se dá o caso dos sistemas vivos, por oposição aos sistemas em equilíbrio. O sistema permanece constante em sua composição, a despeito de contínuos processos irreversíveis, importação e exportação, construção e demolição, estarem em ação. (BERTALANFFY, 2009, p. 186)

\footnotetext{
${ }^{67}$ Do inglês: "[...] pattern or predictability of particular events within a larger aggregate of events is technically
} called "redundance"”. 
A abertura de uma máquina é o fator que torna possível "[...] acoplar duas ou mais máquinas inteiras de modo a formar uma máquina; e qualquer máquina pode ser encarada como constituída pelo acoplamento de suas partes, por sua vez concebíveis como pequenas submáquinas." (ASHBY, 1970, p. 57) Os acoplamentos são uma propriedade importante para as concepções sistêmicas, uma vez que, devido a eles, "[...] a mesma organização pode ser definida como diferentes sistemas, com diferentes tipos de componentes, desde que estes componentes tenham as propriedades que permitam as relações requeridas." ${ }^{68}$ (VARELA; MATURANA; URIBE, 1974, p. 188)

Os resultados dos acoplamentos entre máquinas abertas dependem das propriedades de cada máquina e podem se dar de forma violenta ou não-violenta. No primeiro caso há uma agressão ao funcionamento interno de pelo menos uma das máquinas e, por isso, não costuma ser um tipo de acoplamento muito desejado nas máquinas construídas pelo homem. Já o segundo tipo de acoplamento ocorre de tal forma que as máquinas permanecem com seu funcionamento interno inalterado, ou seja, as partes são deixadas de lado, independentemente de sua acessibilidade estrutural, e são alteradas apenas as relações entre suas entradas e saídas (ASHBY, 1970).

Uma vez que permitem interações com o ambiente, os acoplamentos também são capazes de configurar laços de realimentação, onde as relações de causa e efeito podem não ser claramente isoláveis (ASHBY, 1970; MORIN, 2007c). Os laços de realimentação criados por tais conexões são uma propriedade comum às redes e fazem com que as interações se propagem por todo o sistema (CAPRA, 2006). Neste sentido, os acoplamentos assumem um papel central para a compreensão dos sistemas complexos, como os sistemas vivos e os sócio-sistemas.

O estudo cibernético das relações entre máquinas também assume especial importância para o problema da organização. Os laços de realimentação produzidos pelos acoplamentos entre sistemas, tiveram grande importância para explicar as dinâmicas que levam determinados tipos de mecanismos, dentre eles o seres vivos, a se manterem em dinâmicas estáveis, mesmo longe do equilíbrio (PIERCE, 1980; BAUER, 1999; CAPRA, 2006; BERTALANFFY, 2009). A dinâmica de auto-regulação utilizada por tais sistemas foi formulada em termos biológicos, dentro do conceito de homeostase (BERTALANFFY, 2009).

68 Do inglês: "[...] the same organization may be realized in different systems with different kinds of components as long as these components have the properties which realize the required relations." 
A idéia por trás da homeostase pode ser descrita por meio de um simples dispositivo auto-regulador, proposto por Ashby (1970). Este dispositivo, denominado homeostato, consiste em um conjunto de duas máquinas acopladas em um sistema de realimentação circular, onde as entradas de uma máquina são a saída da outra máquina e, vice-versa. Neste sistema, uma das máquinas veta todos os demais estados da outra, que não representem o estado programado como aceitável. Com isso, mesmo que o sistema da primeira máquina seja perturbado, ele vai variar aleatoriamente até que retorne ao estado programado, através do veto da outra máquina a todos os estados que venham a divergir do mesmo (ASHBY, 1970; PIERCE, 1980).

Uma versão simplificada do homeostato de Ashby (1970) pode ser ilustrada por meio de dois dispositivos A e B acoplados, onde A possui quatro indicadores capazes de representar as três cores primárias e B possui um relé e quatro seletores para cada uma das três cores primárias. A máquina $A$ envia o estado de seus indicadores para a máquina $B$ e altera aleatoriamente as cores de seus indicadores, a cada período de tempo $t$, enquanto estiver recebendo energia. A máquina $B$ opera como dispositivo regulador, de tal modo que enquanto a máquina $A$ apresentar uma combinação de cores diferente da programada em seus seletores, ela continua lhe fornecendo energia. Quando a máquina B identifica que a máquina A atingiu a configuração ajustada em seus reguladores, ela interrompe o fornecimento de energia para a mesma, o que paralisa os indicadores nas cores ajustadas nos reguladores da máquina $\mathrm{B}$ - ver figura 18.

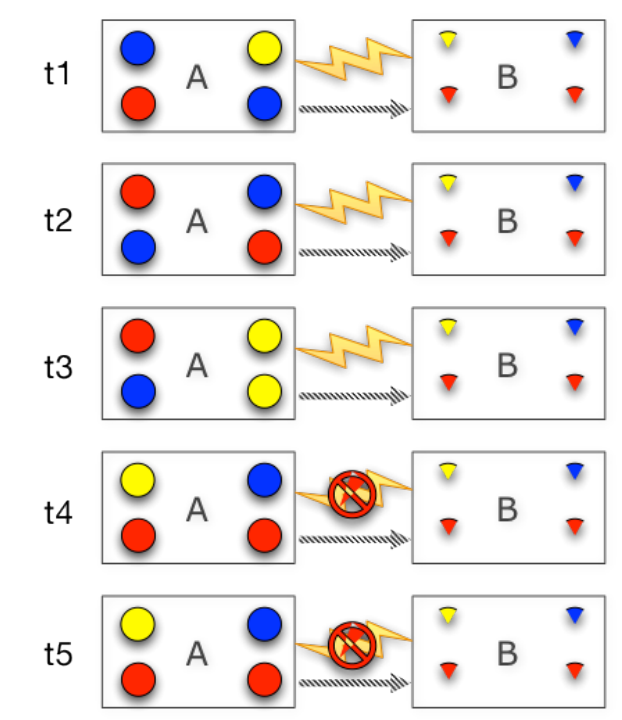

Figura 18 - Funcionamento do homeostato. Adaptado de: Ashby (1970) 
É importante notar que neste tipo de sistema as máquinas se afetam mutuamente por meio de um laço de realimentação circular, de tal forma que mesmo que uma fonte de energia externa perturbe temporariamente a máquina $A$ e ela recomece suas interações aleatórias, a máquina B volta a vetar os estados fora do programado, até que o sistema como um todo retorne ao estado programado.

Portanto, através de laços de realimentação, uma máquina homeostática consegue se manter operando dentro de limites de variações aceitáveis, mesmo em estados distantes do equilíbrio termodinâmico e sob pressão do ambiente (BERTALANFFY, 2009). Em termos gerais Glass e Mackey (1997, p. 22) sugerem que, em essência, a auto-regulação “[...] pode associar-se à noção de estados estacionários em matemática." Devido a esta característica, a homeostase pode explicar a manutenção da estabilidade de um sistema, mas não consegue esclarecer, por si só, a emergência de novos padrões de organização, tão comuns nos organismos vivos e sociais.

A explicação para esta característica começou a ser desvendada por meio dos esforços dos pesquisadores da área da inteligência artificial. Durante a década de 1940, Warren McCulloch e Walter Pitts desenvolveram o modelo matemático daquilo que seria o primeiro neurônio artificial. O dispositivo desenvolvido pelos pesquisadores consiste em um comutador binário, capaz de ser integrado em forma de rede e de assumir as posições ligado e desligado, de acordo com regras de comutação pré-estabelecidas (KHANNA, 1990; PRINCIPE; EULIANO; LEFEBVRE, 1999; CAPRA, 2006).

$\mathrm{Na}$ década de 50 , os cientistas começaram a construir efetivamente modelos dessas redes binárias, inclusive alguns com pequeninas lâmpadas que piscavam os nodos. Para seu grande espanto, descobriram que, depois de um breve tempo de bruxuleio aleatório, alguns padrões ordenados passavam a emergir na maioria das redes. Eles viram ondas de cintilação percorrerem a rede, ou observaram ciclos repetidos. Mesmo que o estado inicial da rede fosse escolhido ao acaso, depois de um certo tempo esses padrões ordenados emergiam espontaneamente, e foi essa emergência espontânea de ordem que se tornou conhecida como "autoorganização". (CAPRA, 2006, p. 79)

A auto-organização é uma propriedade inerente a qualquer sistema vivo (SKÅR, 2003; CAPRA, 2006). Neste contexto, “[...] a auto-organização parece se caracterizar pela criação quase espontânea de padrões globais ou semi-globais desenvolvidos a partir de interações 
locais entre componentes ou agentes, independentes e autônomos." ${ }^{69}$ (SKÅR, 2003, p. 1054, tradução nossa) Diante da concepção de ascensão de padrões ordenados, a ideia de autoorganização vai claramente de encontro com a segunda lei da termodinâmica.

“De acordo com o segundo princípio da termodinâmica, a tendência geral dos processos físicos segue o rumo da entropia crescente, isto é, estados de probabilidade crescente e ordem decrescente." (BERTALANFFY, 2009, p. 188) Conforme lembra Gleiser (2010), na natureza jamais se observou uma condição que contrariasse a segunda lei da termodinâmica. Uma vez que a tendência natural do universo é o caminho para a desordem e o equilíbrio, os sistemas auto-organizantes não podem ser sistemas fechados, como proposto pelos modelos termodinâmicos, eles precisam ser capazes de importar ordem do meio, para se manterem organizados em estados distantes do equilíbrio. Portanto, um sistema auto-organizado, como os sistemas vivos, “[...] só preserva ou aumenta a ordem interna mediante uma contribuição para a desordem do mundo externo [...]."(MARGULIS; SAGAN, 2002, p. 33)

Assim, a abertura dos sistemas é um requisito fundamental para que estes possam se auto-organizar e evoluir no decorrer do tempo (PRIGOGINE, 2002). Este tipo de sistema precisa de um fluxo contínuo de matéria e energia passando através do mesmo. Desse modo, pode-se dizer que as máquinas auto-organizadas são máquinas abertas, cuja dinâmica Ihes permite tirar proveito do ruído introduzido pelo meio, para sustentar seus próprios padrões de organização. Esta concepção de exportação de entropia a partir de trocas externas, foi denominada de ordem pelo ruído (BATESON, 1967; CAPRA, 2006).

Diante desta característica essencial dos sistemas auto-organizados, o conceito de redundância assume especial importância. Para lidar com o ruído e tirar proveito do mesmo, é preciso que este tipo de máquina cultive uma ampla variedade de ações. Só assim ela é capaz de lidar com as perturbações ambientais. Desse modo, a redundância se encontra intimamente ligada com a sobrevivência dos sistemas auto-organizados, dentre eles os sistemas vivos e aqueles deles derivados (HEYLIGHEN, 1992; PASCALE, 2002). Neste sentido, Atlan (1974) ressalta que:

\footnotetext{
${ }^{69}$ Do inglês: "[...] self-organization seems to be characterized by the almost spontaneous creation of global or semi-global patterns developed from local interactions among independent and autonomous components or agents. Creation and patterns are two basic components of self-organization."
} 
[...] desde que a sua redundância e a confiabilidade funcional inicial sejam grandes o suficiente para permitir um período observável de auto-organização, um sistema pode reagir a tensões ambientais aleatórias por meio de um aumento da complexidade e variedade, de modo que parece se adaptar mesmo a um novo ambiente. ${ }^{70}$ (ATLAN, 1974, p. 303, tradução nossa)

Os sistemas auto-organizáveis diferem significativamente daqueles que se utilizam de um programa externo para se manterem organizados. Eles não só são capazes de suportar as perturbações do meio, como continuam funcionando de maneira diferente após a mesma (ATLAN, 2001). Contudo, a emergência de uma nova ordem, provocada pelas perturbações externas, implica que a redundância, por si só, não é suficiente para a manutenção da autoorganização, no decorrer do tempo (ATLAN, 2001).

Diante de uma nova ordem emergente, o sistema pode sofrer uma alteração em suas regras de funcionamento. Nestas condições o sistema não precisa só lidar com o ruído, como também precisa ser capaz de utilizar a nova organização criada por meio desta interação. Em outras palavras, o sistema também depende que as novas conexões geradas por sua interação com o ambiente, se configurem de tal forma que Ihe permitam permanecer funcional (ATLAN, 2001). Com base nestas constatações Atlan (2001) conclui que:

[...] Há duas razões possíveis para os sistemas organizados não serem autoorganizantes: ou a sua redundância é muito pequena e fatores aleatório produzidos pelo ruído só podem destruí-los - mais rapidamente ou mais lentamente de acordo com a sua confiabilidade - ou, apesar da redundância inicial suficientemente grande, a sua confiabilidade não é alta o suficiente para permitir a autoorganização dos processos, para que este permaneça durando um período considerável de tempo. ${ }^{71}$ (ATLAN, 1974, p. 302, tradução nossa)

Desse modo a máquina auto-organizada difere da organização determinada. Conforme lembram Maturana e Varela (1997), os sistemas que contém esta particularidade são capazes de ajustar seus programas internos de forma independente de um operador externo e, assim, são dotados de um fechamento operacional e de certa intencionalidade, inerente à sua própria evolução. Portanto, um sistema auto-organizante é uma máquina aberta, que se fecha em sua estrutura, assim como os sistemas determinados. Este tipo de sistema se comporta de maneira autônoma e intencional em relação aos estímulos do

\footnotetext{
${ }^{70}$ Do inglês: "[...] provided that its initial redundancy and functional reliability are large enough to allow for an observable period of self-organization, a system can react to random environmental stresses by an increase in complexity and variety, so that it appears to adapt itself to its-even new-environment."

${ }^{71}$ Do inglês: “" [...] there are two possible reasons for organized systems not to be self-organizing: either their redundancy is too small and random noise-producing factors can only destroy them-faster or slower according to their reliability-or, in spite of an initial redundancy large enough, their reliability is not high enough to allow for self-organizing processes to take place during an appreciable period of time."
} 
ambiente e, portanto, envolve dinâmicas análogas a muitas das encontradas nos sóciossistemas humanos. De acordo com Capra (2006), as propriedades auto-organizantes de um sistema vivo ou se um sócio sistema implicam que tendo a intenção e a capacidade de fazêlo, este tipo de sistema pode até mesmo se desconectar de subsistemas que estão forçando rupturas danosas ao estado de estabilidade dinâmica.

Portanto, a auto-organização se caracteriza por apresentar alguns princípios que podem ser vistos no quadro 9. Com base nestes princípios é possível identificar que a estrutura em rede dos sócios-sistemas humanos, pode caracterizá-lo como um sistema autoorganizante. Capra (CAPRA, 2006) exemplifica estas propriedades ao afirmar que:

[...] uma comunidade que mantém uma rede ativa de comunicação aprenderá com os seus erros, pois as consequências de um erro se espalharão por toda a rede e retornarão para a fonte ao longo de laços de alimentação. Desse modo, a comunidade pode corrigir seus erros, regular a si mesma e organizar a si mesma. (CAPRA, 2006, p. 78)

\section{Principais características dos sistemas auto-organizantes}

1. Seus componentes estão interligados por uma rede de laços de feedback.

2. São máquinas abertas e fazem parte de seu ambiente.

3. Podem apresentar aumento de seu nível de ordem.

4. Apresentam um fluxo de energia que permite a eles se auto-organizar espontaneamente e manter uma estrutura em condições distantes do equilíbrio.

5. Podem criam estruturas originais e novos modos de comportamento.

6. Seus componentes são tão numerosos que não há nenhuma maneira de se estabelecer uma relação causal entre eles.

Quadro 9 - Principais características dos sistemas auto-organizantes Adaptado de: Sardar e Abrams (1999, p. 77)

Em síntese, pode-se dizer que as evoluções - já que não se trata de uma revolução propriamente dita - trazidas pela ciência da Cibernética foram notáveis e trouxeram um novo fôlego para a compreensão dos aspectos dinâmicos da natureza. Elas trazem em seu cerne uma nova concepção qualitativa do mundo que nos cerca, cujos princípios básicos que se encontram abordados no quadro 10 - apresentam propriedades intrínsecas a diversos fenômenos biológicos e sociais, pouco explicados pelos paradigmas anteriores. 


\section{Sete Princípios da Cibernética}

1. Retenção Seletiva: afirma que os sistemas com configurações mais estáveis tendem a ser retidos por serem mais difíceis de serem eliminados, enquanto as configurações mais instáveis são eliminadas com maior facilidade.

2. Crescimento Auto-catalítico: afirma que sistemas com configurações estáveis apresentam maior facilidade de se reproduzirem e, portanto, tendem a ter maior crescimento populacional.

3. Transição Assimétrica: Afirma que a probabilidade de uma configuração menos estável evoluir para uma mais estável é maior do que a de uma configuração mais estável evoluir para uma menos estável.

4. Variação Cega: É uma hipótese, amparada pelo princípio lógico da navalha de Occam, que afirma que as variações que sustentam a evolução dos sistemas vivos são randômicas.

5. Variedade Seletiva: Afirma que quanto maior a quantidade de variações produzidas por um determinado sistema, maior a chance de uma destas variedades se perpetuar.

6. Construção Recursiva do Sistema: Afirma que um sistema precisa se utilizar de blocos de construção mais estáveis (normalmente menores) para construir novas combinações de sistemas estáveis.

7. Conhecimento Incompleto: Este princípio se baseia no princípio da incerteza de Heisenberg e pressupõe que um sistema de controle, por melhor que seja, sempre possui um conhecimento incompleto e, portanto, está sujeito a ser surpreendido por incertezas.

Quadro 10 - Princípios da Cibernética

Adaptado de: Heylighen (1992)

A Cibernética permitiu que o homem e as organizações fossem extraídos de seu isolamento e passassem a ser entendidos como entes acoplados em um sistema maior. Nesta concepção as relações de causa e efeito se perdem diante dos laços de realimentação e o sentido natural dos fenômenos fica livre para ir além da morte termodinâmica e importar do meio a vida e a ordem, tão necessárias para o bem estar dos sistemas sociais humanos. Esta nova ciência, dá ao homem a possibilidade de se considerar parte do meio que o cerca e ver na sobrevivência do mesmo os subsídios para sua própria sobrevivência.

Contudo, a Cibernética também trás em seu cerne os problemas inerentes à descrição das interconexões que formam os laços de realimentação. Conforme visto no capítulo 2.5, tais tipos de sistemas exigem uma descrição matemática distinta daquela adotada pelas máquinas determinadas da física clássica. Eles precisam de uma estrutura matemática capaz de produzir descrições de dinâmicas não-lineares, onde os resultados se abrem em múltiplas possibilidades. Esta nova linguagem só viria a emergir na década de 1970, com o desenvolvimento da nova matemática do Caos. 


\subsection{A MATEMÁTICA DO CAOS E A DINÂMICA DA COMPLEXIDADE}

James Clerk Maxwell foi um dos pioneiros no uso de métodos estatísticos para entender as regularidades das complexas interações ocorridas entre as moléculas dos gases. Este conceito foi aplicado na termodinâmica para descrever quantidades médias em sistemas complexos. Contudo, esta concepção, assim como as equações newtonianas para o movimento, ainda era baseada em descrições lineares, estruturadas em princípios isoláveis de causa e efeito. Desse modo, mesmo diante das notáveis descrições estatísticas de Maxwell, a dinâmica da complexidade ainda carecia de uma descrição matemática própria, capaz de também oferecer descrições robustas para os sistemas não-lineares (CAPRA, 2006).

Foi a matemática do Caos que incorporou as sofisticadas concepções, baseadas nas relações e nos padrões, necessárias para descrição dos sistemas complexos. 0 desenvolvimento desta nova matemática foi impulsionado no decorrer da década de 1970, a partir das notáveis observações realizadas pelo meteorologista Edward Lorenz, em 1961.

Enquanto trabalhava em simulações computacionais para previsão do tempo, Lorenz testou um modelo de sistema climático, composto por três equações não-lineares acopladas. Após uma das mais importantes pausas para o café da história da ciência, Lorenz observou que pequenos arredondamentos que ele havia feito nas entradas do modelo, tinham produzido resultados completamente distintos em suas previsões climáticas. Com base nesta constatação Lorenz percebeu que os modelos de sistemas climáticos tinham resultados extremamente sensíveis às condições iniciais. Esta propriedade ficou conhecida como "Efeito Borboleta" (GLEICK, 1988; SARDAR; ABRAMS, 1999; CAPRA, 2006; MATTHEWS, 2008).

Neste tipo de sistema, "erros e incertezas se multiplicam, evoluindo em cascata através de uma cadeia de feições turbulentas [...]". ${ }^{72}$ (GLEICK, 1988, p. 20) A sensibilidade às condições iniciais faz com que a distância entre duas trajetórias, inicialmente próximas, aumente de forma exponencial com o passar do tempo. Aos sistemas com tais divergências foi dado o nome de sistemas caóticos (GLEICK, 1988; SARDAR; ABRAMS, 1999; PRIGOGINE,

\footnotetext{
72 Do inglês: "Errors and uncertainties multiply, cascading upward through a chain of turbulent features [...]".
} 
2002; CAPRA, 2006). Portanto, “[...] os sistemas caóticos são caracterizados por uma extrema sensibilidade às condições iniciais." (CAPRA, 2006, p. 115)

Um aspecto importante percebido na dinâmica dos sistemas caóticos é a presença daquilo que foi denominado de atrator. "Um atrator é um conjunto de pontos S tal que, para quase qualquer ponto na vizinhança de $S$, a dinâmica aproxima-se de $S$ à medida que $t$ se aproxima do infinito." (GLASS; MACKEY, 1997, p. 64) Em termos simplificados, um atrator é um ponto fixo no sistema de coordenadas, que atrai a trajetória de evolução do sistema em sua direção. Para surpresa dos pesquisadores da matemática do caos, eles "[...] descobriram que há um numero muito limitado de atratores diferentes. Suas formas podem ser classificadas topologicamente, e as propriedades dinâmicas gerais de um sistema podem ser deduzidas da forma de seu atrator." (CAPRA, 2006, p. 114)

Os matemáticos que se dedicaram às pesquisas desta área identificaram três tipos básicos de atratores, capazes de descrever as dinâmicas dos mais variados tipos de sistemas. Os atratores que definem a dinâmica dos sistemas que orbitam um ponto no espaço de coordenadas por meio de uma trajetória que forma um laço fechado, onde existem oscilações periódicas, foram denominados de "atratores periódicos". Aqueles que determinam a dinâmica de sistemas onde a evolução forma uma espiral em direção a um determinado ponto, foram denominados de "atratores puntiformes". Por fim, os atratores que causam uma dinâmica do sistema na qual os comportamentos nunca se repetem, mas formam um padrão complexo e não aleatório, onde os padrões quase se repetem, foram denominados de "atratores estranhos". Enquanto os atratores periódicos e puntiformes correspondem às descrições de sistemas com comportamento estável ou que caminham para a estabilidade, os atratores estranhos são aqueles que originam os sistemas caóticos e, portanto, as dinâmicas em torno do mesmo apresentam elevada sensibilidade às condições iniciais (GLEICK, 1988; GLASS; MACKEY, 1997; SARDAR; ABRAMS, 1999; CAPRA, 2006).

"Todas as trajetórias que começam dentro de uma certa região do espaço de fase levarão, mais cedo ou mais tarde, ao mesmo atrator. Essa região é denominada "bacia de atração" desse atrator." O espaço é separado em diversas bacias de atração, com seus respectivos atratores (CAPRA, 2006, p. 117). Uma implicação desta concepção, é que a análise de um sistema dinâmico deve se dar de forma qualitativa, a partir da identificação e da classificação dos atratores de um sistema e suas bacias de atração. O resultado desta 
análise é um quadro geral qualitativo do problema, denominado "retrato de fase" (CAPRA, 2006).

\begin{abstract}
Desse modo, vemos que o comportamento caótico, no novo sentido científico do termo, é muito diferente do movimento aleatório, errático. Com a ajuda de atratores estranhos, pode-se fazer uma distinção entre a mera aleatoriedade, ou "ruído", e o caos. O comportamento caótico é determinista e padronizado, e os atratores estranhos nos permitem transformar os dados aparentemente aleatórios em formas visíveis distintas. (CAPRA, 2006, p. 115)
\end{abstract}

Contudo, mesmo sob uma perspectiva determinista, a dinâmica dos sistemas caóticos apresenta implicações significativas, já que:

\begin{abstract}
até mesmo os computadores mais poderosos arredondam os seus cálculos após um certo numero de casas decimais, e, depois de um certo numero de iterações, até mesmo os mais diminutos erros arredondados terão se acumulado a ponto de produzirem uma incerteza suficiente para tornar impossíveis as previsões. (CAPRA, 2006, p. 109)
\end{abstract}

Diante desta compreensão determinista do caos, as predições das trajetórias em sistemas caóticos, estão limitadas a uma probabilidade que diminui gradualmente com o decorrer do tempo, até que estas trajetórias se percam. "A forma mais comum de medir [esta] força do caos é calcular a escala de tempo de Lyapunov, que captura a taxa pela qual os erros crescem ao longo do tempo." Este coeficiente permite determinar o horizonte temporal no qual é possível se ter algum nível de previsibilidade acerca das trajetórias em sistemas com comportamentos sensíveis às condições iniciais (PRIGOGINE, 2002; MATTHEWS, 2008, p. 124). Neste contexto, o indeterminismo “[...] não deve ser confundido com ausência de previsibilidade, que tornaria ilusória toda ação humana. É de limite à previsibilidade que se trata." (PRIGOGINE, 1996, p. 115)

Contudo, esta ainda era uma imagem determinista do caos, na qual "[...] a irreversibilidade devia-se às nossas aproximações e à nossa ignorância. Assim, éramos nós que introduzíamos a irreversibilidade numa natureza que por si é determinista e reversível no tempo." (PRIGOGINE, 2002, p. 29) Contudo, a concepção determinística do caos não se mostra suficiente para descrever certos aspectos referentes à auto-organização e o caráter criativo da natureza.

O passo mais importante no sentido de construir uma concepção capaz de compreender a auto-organização, foi dado pelo químico belga llya Prigogine, quando este descreveu as formulações matemáticas daquilo que denominou de estruturas dissipativas 
(PRIGOGINE, 1996; SARDAR; ABRAMS, 1999; PRIGOGINE, 2002). “De acordo com a teoria de Prigogine, as estruturas dissipativas não só se mantém num estado estável afastado do equilíbrio como podem até mesmo evoluir." (CAPRA, 2006, p. 82-83).

Prigogine (1996, p. 63) constatou que diferente dos sistemas fechados, onde a entropia "[...] aumenta de maneira monótona ao longo do tempo, até seu valor máximo correspondente ao equilíbrio termodinâmico", nos sistemas dissipativos há uma transferência de entropia nas fronteiras do sistema, capaz de conduzir o mesmo a novos níveis de ordem. Portanto, estes sistemas se nutrem de entropia negativa, para compensar o seu aumento de entropia interna e, assim, manterem-se em dinâmicas distantes da estabilidade. Apesar da aparente simplicidade, esta notável descoberta é a essência por trás sistemas auto-organizados, distantes do equilíbrio e dos sistemas vivos (PRIGOGINE, 1996).

O exemplo mais simples de estrutura dissipativa que podemos evocar por analogia é a cidade. Uma cidade é diferente do campo que a rodeia; as raízes dessa individualização estão nas relações que ela mantém com o campo adjacente: se estas fossem suprimidas a cidade desapareceria. (PRIGOGINE, 2002, p. 21-22)

Portanto, para se manterem em condições que Ihes permitam se auto-organizar, os sistemas dissipativos precisam ser atravessados por um fluxo constante de correlações, capazes de produzir propriedades emergentes. As correlações atravessam de um componente a outro do sistema, de tal forma que um determinado componente sempre transferirá ao seguinte parcelas de suas interações passadas. Neste contexto, as interações conservam uma memória do passado que enfraquece com o passar do tempo. "Pode-se até considerar que seja este o modo de envelhecer do sistema." (PRIGOGINE, 2002, p. 69)

Se tomarmos como objeto de comparação a sociedade humana e confrontarmos a sociedade da era neolítica com a atual, não é tanto o fato de que os homens tomados individualmente sejam diferentes, mais ou menos inteligentes: são antes as relações entre os indivíduos que sofrem uma mudança radical. Sem dúvida, também a nossa sociedade envelhece, mas mais rapidamente que a sociedade neolítica, porque os meios de comunicação se ampliaram e, portanto, a dinâmica das correlações sociais sofreu uma enorme aceleração. (PRIGOGINE, 2002, p. 70)

Estas redes de relação presentes nos sistemas dissipativos, possuem propriedades que Ihes conferem múltiplos laços de realimentação. Conforme visto anteriormente, este tipo de dinâmica provoca situações que só podem ser descritas por meio de equações nãolineares. Este tipo de descrição implica, portanto, em múltiplas soluções. Neste contexto a não-linearidade deste tipo de sistema requer que, em determinados momentos, o sistema 
se veja obrigado a "escolher" entre duas ou mais trajetórias possíveis (PRIGOGINE, 1996, 2002). Prigogine $(1996,2002)$ denominou estes momentos de pontos de bifurcação.

Nestas condições:

Atratores podem desaparecer ou converter-se uns nos outros, ou novos atratores podem aparecer subitamente. Diz-se que esses sistemas são estruturalmente instáveis, e os pontos críticos de instabilidade são denominados "pontos de bifurcação", pois são pontos na evolução do sistema, nos quais aparece subitamente um forqueamento, e o sistema se ramifica em uma nova direção. (CAPRA, 2006, p. 117)

De acordo com Prigogine $(1996,2002)$ esta propriedade inclui um elemento probabilístico que representa cada uma das possibilidades que o sistema pode seguir, diante de um destes entroncamentos. O gráfico 3 ilustra a dinâmica de um dado sistema dissipativos ao passar por esta condição. No gráfico o sistema atinge um ponto de bifurcação em um dado momento $\lambda_{c}$. Se as flutuações forem suprimidas do sistema, este permanecerá instável indefinidamente. Entretanto, se forem inseridas flutuações, mesmo que sutis, o sistema escolherá uma das possíveis ramificações nas trajetórias, que implicará em uma nova trajetória estável (PRIGOGINE, 1996, 2002). “Portanto, os sistemas não são estruturalmente estáveis nos pontos de bifurcação." (GLASS; MACKEY, 1997, p. 44).

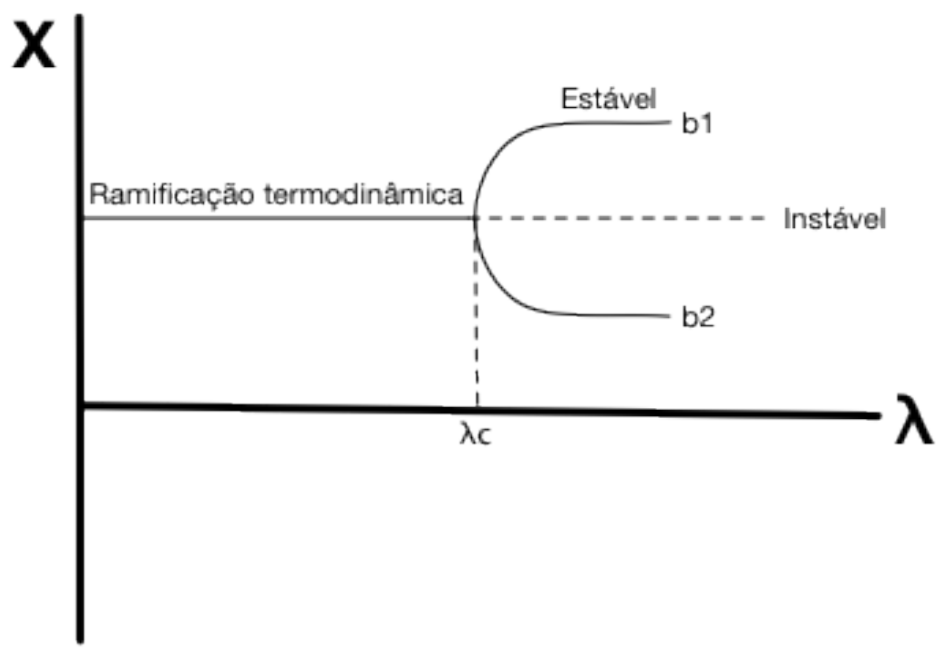

Gráfico 3 - Escolha das trajetórias em um ponto de bifurcação Fonte: Prigogine (1996, p. 72)

Matematicamente, um ponto de bifurcação representa uma dramática mudança da trajetória do sistema no espaço de fase. Um novo atrator pode aparecer subitamente, de nova direção de modo que o comportamento do sistema como um todo "se bifurca", ou se ramifica, numa nova direção. (CAPRA, 2006, p. 143) 
A partir de um ponto de bifurcação as estruturas dissipativas podem assumir novas propriedades oriundas da formação de elementos intermediários, assim como ocorre nos sistemas vivos. Consequentemente, os sistemas dissipativos apresentam a propriedade de se auto-organizar e adquirir novas características emergentes, a partir de flutuações ambientais (PRIGOGINE, 1996, 2002; SKÅR, 2003). Por meio desta teoria, Prigogine demonstrou, então, que estas rupturas, ocorridas nos pontos de bifurcação, culminam com novas formas de ordem que só são possíveis em sistemas abertos, afastados do equilíbrio termodinâmico (PRIGOGINE, 1996).

“Em geral, temos uma sucessão de bifurcações [...]. Este esquema faz coexistirem zonas deterministas (entre as bifurcações) e pontos de comportamento probabilista (os pontos de bifurcação)." - ver gráfico 4 (PRIGOGINE, 1996, p. 73). Portanto, "[...] até mesmo em nível macroscópico a nossa predição de futuro mistura determinismo e probabilidade. No ponto de bifurcação, a predição tem caráter probabilístico, ao passo que entre pontos de bifurcação podemos falar de leis deterministas." (PRIGOGINE, 2002, p. 28) Desse modo, pode-se dizer que "as bifurcações são uma fonte de quebra de simetria." (PRIGOGINE, 1996, p. 73)

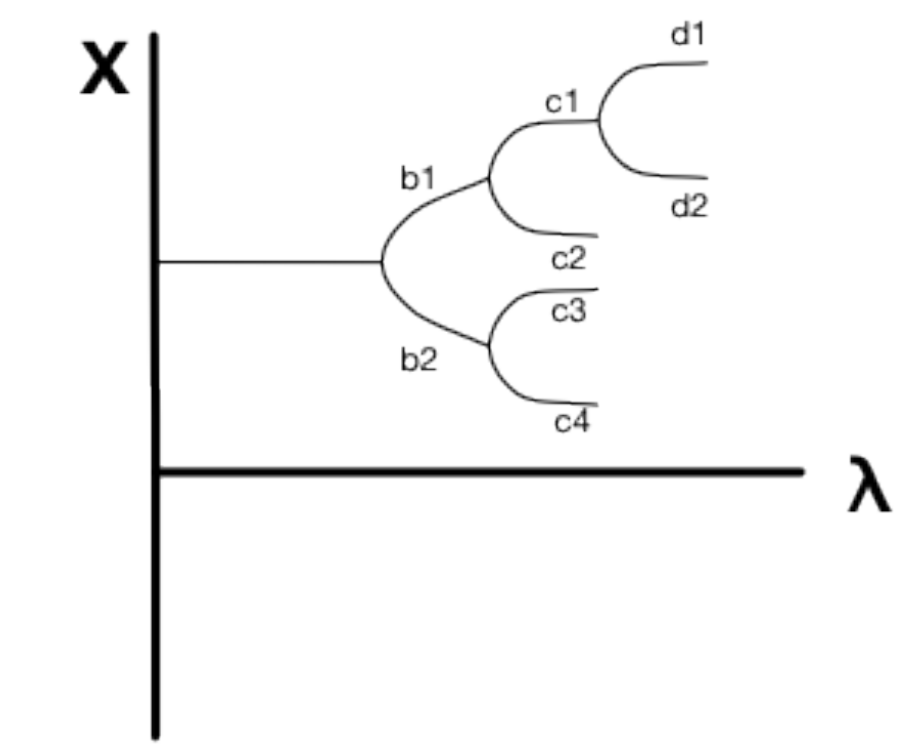

Gráfico 4 - Bifurcações sucessivas em um sistema de não-equilíbrio Fonte: Prigogine (1996, p. 73)

Portanto, as características do Caos em sistemas dissipativos remetem à noção de que se faz necessário descrever o sistema frente às suas probabilidades de evolução, onde a 
presença de uma seta do tempo se torna fundamental para relacionar a criatividade da vida à própria dinâmica de evolução do universo (PRIGOGINE, 2002). Diante desta, concepção é possível determinar por quais rupturas um sistema passou, por meio da posição atual do mesmo - tomando por base o gráfico 4, se sabemos que o sistema encontra-se em d2, então sabemos que passou por b1 e c1. Entretanto, não é possível saber com certeza qual caminho o sistema tomará em um ponto de bifurcação (PRIGOGINE, 1996).

Além disso, as estruturas dissipativas ainda estão sujeitas à problemática da sensibilidade às condições iniciais, devido às suas equações não-lineares. Estas duas características conjugadas - pontos de bifurcação e sensibilidade às condições iniciais tornam os sistemas dissipativos altamente imprevisíveis, mesmo em seus bolsões deterministas. Desse modo, qualquer aproximação torna impossível fazer qualquer previsão à longo prazo para estes sistemas, mesmo entre os pontos de bifurcação (CAPRA, 2006).

Portanto, mesmo o conhecimento das trajetórias do passado se perdem com o passar do tempo, tornando impossível que se conheça, a partir do presente, tanto os estados futuros como os estados passados de um determinado sistema dissipativo. Neste contexto, é importante ressaltar que, mesmo diante do caráter evolutivo do sistema, o conhecimento do passado deve ser tratado como limitado. O enfraquecimento das correlações ocorridas no sistema, implica em uma perda gradual de sua memória (PRIGOGINE, 1996).

Neste sentido também é importante ressaltar que, quando as mudanças organizacionais se dão por meio de uma única unidade, como uma célula ou uma única sociedade, o que existe é uma progressão a partir da ontogenia, que descreve o processo de desenvolvimento de uma unidade no decorrer do tempo. Assim sendo, uma organização social com identidade própria não esta sujeita à evolução e sim à ontogenia. Só se pode falar em evolução em sistemas, quando as alterações organizacionais se dão por meio de sucessão de unidades, ou seja, diferentes unidades progredindo uma da outra. No contexto da evolução, é impossível avaliar uma unidade presente, com base na evolução histórica. 0 desenvolvimento histórico é uma característica inerente à ontogenia. Neste sentido é a ontogenia que confere às sociedades o seu caráter histórico (MATURANA; VARELA, 1997).

Portando, "a introdução do caos obriga-nos a generalizar a noção de lei da natureza e nela introduzir os conceitos de probabilidade e de irreversibilidade." (PRIGOGINE, 2002, p. 11) Sob esta perspectiva: 
"[...] é do caos que surgem ao mesmo tempo ordem e desordem. Se a descrição fundamental se fizesse com leis dinâmicas estáveis, não teríamos entropia, mas tampouco coerência devida ao não-equilíbrio, nem nenhuma possibilidade de falarmos de estruturas biológicas e, portanto, um universo de que o homem estaria excluído." (PRIGOGINE, 2002, p. 80)

Neste ponto cabe ressaltar que trabalhos recentes, realizados por Vilar e Rubí (2001) e Reguera, Rubí e Vilar (2005), mostram que o universo é regido por bolsões de ordem e desordem que quando submetidos a uma linha evolutiva apontam para uma tendência geral que caminha para a desordem. Portanto, a ordem a partir do caos não contraria a segunda lei da termodinâmica, mas usufrui de uma particularidade possibilitada pela abertura dos sistemas.

Vilar e Rubí (2001) e Reguera, Rubí e Vilar (2005) demonstraram que a ordem se desenvolve em bolsões movidos por forças externas, em um universo que caminha para a degeneração, conforme prevê a segunda lei da termodinâmica. Deste modo, os sistemas dissipativos atuam em uma condição onde a degeneração não é constante e sim uma degeneração desafiada, invariavelmente, pela criatividade e a pela ordem emergente, oriunda da captura de entropia negativa do meio externo. Desse modo, mesmo com a ascensão constante de novas formas de ordem, o caminho natural para qualquer sistema, inclusive o universo como o conhecemos, é o da desordem e do equilíbrio termodinâmico. Em outras palavras, os autores constataram que qualquer sistema caminha invariavelmente para a morte, independentemente de suas capacidades de auto-organização.

Ao analisar os sócios-sistemas humanos, tendo por base as analogias mostradas por Prigogine (2002), percebe-se que estes apresentam características que lhes permitem ser entendidos como sistemas dissipativos. Nestas condições, pequenos fatores imperceptíveis podem fazer os sócios-sistemas escolherem um caminho ou outro, de forma irreversível. Com base em diversos exemplos de eventos sociais significativos, desencadeados por flutuações aparentemente insignificantes, Morin (2007b, p. 96) concluiu que "a história humana sempre nos mostrou bifurcações históricas, principalmente em épocas de guerra, fenômeno que se tornou muito frequente na história da humanidade." Neste sentido, Pascale (2002, p. 124) afirma que em nossa sociedade "a complexidade emergente não cria um futuro, mas muitos." Com base em concepção similar, Morin (2007b, p. 37) defende que "como o futuro é absolutamente incerto, é preciso pensar com e na incerteza, mas não a 
incerteza absoluta, porque sempre navegamos num oceano de incerteza por meio de arquipélagos de certezas locais."

\subsection{MÁQUINAS PRODUZIDAS PELO HOMEM E MÁQUINAS VIVAS}

Em 1960 Humberto R. Maturana foi motivado por um de seus alunos a dar uma resposta a uma pergunta ainda não respondida até então: "que classe de sistema é um ser vivo?" (MATURANA; VARELA, 1997, p. 11). Já naquela época a Cibernética dava conta de vários dos atributos fundamentais da vida. Conceitos como a Homeostase e a autoorganização emergiam para explicar sofisticados mecanismos de auto-organização e autoregulação, normalmente associados aos organismos vivos.

Conforme visto anteriormente, tais conceitos explicam importantes atributos da vida, mas também são propriedades emergentes em uma série de sistemas construídos pelo homem. Contudo, a vida apresenta particularidades distintivas, cujas dinâmicas ainda não haviam sido exploradas até então. Os organismos vivos se mantém em continua troca de seus componentes, se autorregulam e se consomem, ao mesmo tempo que se conservam em termos de identidade (BERTALANFFY, 2009). "Ilhas de ordem num oceano de caos, os organismos são muito superiores às máquinas construídas pelo homem. Ao contrário da máquina a vapor de James Watt, por exemplo, o corpo concentra a ordem. Ele se refaz continuamente." (MARGULIS; SAGAN, 2002, p. 31)

A máquina viva também apresenta uma capacidade funcional notável. Ela é composta por componentes frágeis e é capaz de se renovar e reparar constantemente, mantendo sua identidade, de tal modo que o conjunto é mais robusto e confiável do que seus frágeis constituintes. Já máquina organizada, produzida pelo homem, é o inverso. Ela pode ser projetada para ser muito confiável e sua confiabilidade é sempre menor do que a confiabilidade de suas peças, tomadas separadamente. Este tipo de máquina também 
precisa de intervenções externas para ser construída e reparada. Ao contrario da máquina viva, que é dotada de sua própria autonomia construtiva (MORIN, 2007c).

Assim sendo, a vida precisa de uma descrição dinâmica que contemple estas capacidades de autocriação e manutenção de identidade de entes distantes do equilíbrio termodinâmico. Maturana se concentrou, então, nesta propriedade da vida - como uma unidade autônoma, capaz criar a si própria - e, juntamente com Francisco J. Varela, iniciou o desenvolvimento de uma nova teoria para classificar o vivente. Os autores denominaram estes sistemas, capazes de se autocriar, de máquina autopoiética. Enquanto aqueles sistemas produzidos pelo homem foram batizados pelos mesmos de máquinas alopoiéticas (VARELA; MATURANA; URIBE, 1974; MATURANA; VARELA, 1997).

Conforme visto anteriormente, a máquina produzida pelo homem possui fronteiras que a definem, assim como a vida, mas tem por particularidade não participar de sua própria criação. Portanto, os "sistemas alopoiéticos são, por sua constituição, não autônomos na medida em que sua realização e permanência como unidades não estão relacionadas com o seu funcionamento." ${ }^{73}$ (VARELA; MATURANA; URIBE, 1974, p. 189, tradução nossa) Mesmo que sua configuração permita a auto-organização, as máquinas alopoiéticas não conseguem se ver livres de um operador, pois não conseguem se auto-reparar ou criar a si mesmas.

Por outro lado, o organismo vivo, descrito por Maturana e Varela (1997), possui um caráter individual e autônomo que o distingue do meio. Eles são dotados de identidade e uma capacidade de se auto-organizar, que lhes garante sua integridade, mesmo quando submetidos a perturbações externas (MATURANA; VARELA, 1997). Uma vez que, conforme ressalta Morin (2007c), estes sistemas só são lógicos enquanto sistemas abertos, então eles assumem uma dinâmica particular, na qual são ao mesmo tempo abertos para o meio e fechados em sua própria organização. Maturana e Varela (1997) denominam esta dinâmica de autopoiética. Desse modo, um ente autopoiético pode ser tratado como um tipo particular de sistema dissipativo onde, "de acordo com a segunda lei da termodinâmica, a auto-sustentação autopoiética só preserva ou aumenta a ordem interna mediante uma contribuição para a desordem do mundo externo [...]." (MARGULIS; SAGAN, 2002, p. 33)

Fica claro diante desta definição que um sistema autopoiético não possui entradas ou saídas no mesmo sentido da máquina cibernética. Ele é fechado em si mesmo e é tal

73 Do inglês: "Allopoietic systems are by constitution non-autonomous insofar as their realization and permanence as unities is not related to their operation." 
característica que garante sua unidade. Todavia, as perturbações do meio podem fazer com que o sistema autopoiético precise responder para manutenção de sua identidade e esta resposta pode produzir resíduos. Neste contexto, os resíduos são análogos às saídas, enquanto as perturbações o são com relação às entradas. Desse modo, as trocas realizadas pelas máquinas autopoiéticas são, na verdade, perturbações, e resíduos gerados pela máquina para neutralizá-los. Portanto, o produto principal de uma máquina autopoiética não é inerente à sua saída, como nas máquinas alopoiéticas, e sim a sua própria organização. Ou seja, as trocas realizadas por um sistema autopoiético possuem por finalidade a manutenção de sua própria identidade (MATURANA; VARELA, 1997).

Dado o determinismo estrutural, uma vez que o sistema surge, seu acontecer
consiste necessariamente numa história de interações recorrentes com os
elementos de um meio que surge com ele e o contém. Além disso, tal história de
interações recorrentes entre o sistema e o meio transcorre necessariamente como
uma derivação estrutural. Isto é, tanto a estrutura do sistema como a estrutura do
meio mudam necessariamente e de maneira espontânea de um modo congruente
e complementar enquanto o sistema conserva sua organização e coerência
operacional com o meio que lhe permite conservar sua organização. (MATURANA;
VARELA, 1997, p. 29-30)

Portanto, afirmam os autores, "[...] os seres vivos são entes históricos participes de um presente histórico em contínua transformação." Assim, não se deve "[...] tentar usar o presente (resultado da história) como argumento causal para explicar sua origem." (MATURANA; VARELA, 1997, p. 31)

Com objetivo de compreender melhor o tipo de dinâmica, presente nos sistemas autopoiéticos, Humberto R. Maturana propôs uma reação química que, para o autor, seria capaz de sintetizar um sistema autopoiético básico - ver quadro 11. Nesta reação, o autor propôs uma substância catalisadora $A$, capaz de formar uma substância $M$ a partir de duas unidades de uma substância $B$. Nela M poderia se unir a outro $M$ ou se desintegrar em duas unidades de B (MATURANA; VARELA, 1997). 


\section{Reação autopoiética sugerida por Humberto R. Maturana}

Sejam as partículas A, B e M e seja seu operar o seguinte:

1. $2 B+A \rightarrow M+A$

2. $\mathrm{M}+\mathrm{M} \rightarrow \mathrm{MM}$

$\mathrm{MM}+\mathrm{M} \rightarrow \mathrm{MMM}$

3. $\mathrm{M} \rightarrow 2 \mathrm{~B}$

4. MMMMMMM é permeável à passagem de $B$

5. A corrente de MS é flexível e móvel, e pode fechar-se sobre si mesma.

Quadro 11 - Reação sugerida por Humberto R. Maturana para simular um sistema autopoiético Fonte: Maturana e Varela (1997, p. 22)

Os resultados desta reação, simulados por computador, foram publicados por Varela, Maturana e Uribe (1974). Os autores constataram que a reação proposta por Maturana foi capaz de formar, espontaneamente, sistemas alopoiéticos, compostos por linhas do composto $\mathrm{M}$, e também sistemas compostos por um invólucro de Ms em torno do catalisador A - ver figura 19.

Nas unidades onde se formaram invólucros, quando este era rompido pela desintegração de algum elemento $\mathrm{M}$, o sistema compensava o dano preenchendo a lacuna com uma nova partícula M. Portanto, tais unidades se mostraram capazes de manter sua identidade a partir de um comportamento autorreferente, onde as características do catalisador, atuam como um atrator para a dinâmica do sistema (VARELA; MATURANA; URIBE, 1974). Os autores haviam criado, então, uma rede autopoiética simulada, mostrando que estas eram possíveis, mesmo a partir de regras extremamente simples.

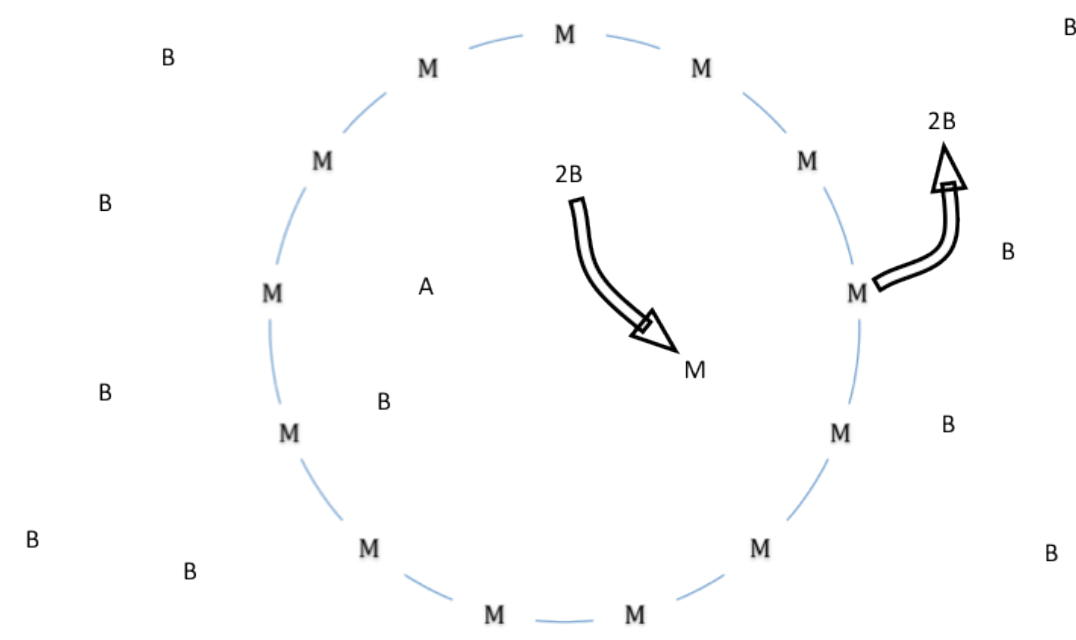

Figura 19 - Unidade autopoiética oriunda das reações sugeridas por Maturana. Fonte: Maturana e Varela (1997, p. 23) 
Com base nesta simulação Varela, Maturana e Uribe (1974) também perceberam uma importante característica dos sistemas autopoiéticos. Em configurações que apresentam este tipo de dinâmica, a taxa de desintegração dos componentes é um fator chave para a manutenção da dinâmica do sistema. Se a taxa de desintegração dos componentes for mais alta do que a taxa de reparo que o sistema autopoiético é capaz de realizar, então a estrutura da rede de interações autopoiéticas se desfaz. Isso "faz da desintegração um limitador muito poderoso do tamanho máximo para uma estrutura de contorno viável."74 (VARELA; MATURANA; URIBE, 1974, p. 194, tradução nossa)

Tal aspecto assume especial importância, pois esta característica dos sistemas autopoiéticos leva este tipo de dinâmica a operar dentro de um limite possível de compensações, que possui relação com suas dimensões e sua taxa de regeneração. Desse modo, em uma rede autopoiética, "[...] qualquer interferência física em seu funcionamento, fora de seu campo de compensações dará por resultado sua desintegração." (MATURANA; VARELA, 1997, p. 74)

Conforme ressaltam Margulis e Sagan (2002, p. 31), "sem o comportamento [autopoiético], os seres orgânicos não se sustentariam - não permaneceriam vivos." Destarte, é importante que uma organização autopoiética tenha um campo de compensação compatível com as variações esperadas, para evitar a ruptura de sua rede autopoiética e, por consequência, consiga evitar que o sistema atinja o equilíbrio termodinâmico - que em última instância significaria a morte do sistema. Contudo, por maior que seja o campo de compensação de uma determinada estrutura, Morin (2007c, p. 89) destaca que "toda organização, como todo fenômeno físico, organizacional e, claro, vivo, tende a se degradar e a degenerar."

Como uma característica emergente em sistemas autorreferentes, a autopoiese também assumiu uma grande importância nas descrições acerca da autonomia dos seres vivos, dentre elas aquelas que se referem a cognição humana. Neste sentido, Maturana e Varela (1988) perceberam que a dinâmica do sistema cognitivo humano atua de acordo com princípios da autopoiese. Esta teoria acerca do processo mental, ficou conhecida como teoria de Santiago. Nela, a mente consiste em um processo autorreferente, que se cria conforme a história de interações entre a máquina cognitiva e o meio que a cerca. Neste

\footnotetext{
${ }^{74}$ Do inglês: "makes the disintegration a very powerful controller of the maximum size for a viable boundary structure."
} 
contexto, Capra (2006) lembra que diante da teoria de Santiago a unidade, representada pelo cérebro, não é um requisito para que a mente ocorra, já que qualquer estrutura dissipativa em rede pode possibilitar a formação deste complexo processo. Logo, "[...] a mente se manifesta não apenas em organismos individuais, mas também em sistemas sociais e em ecossistemas." (CAPRA, 2006, p. 144)

Portanto, a dinâmica autopoiética extrapola o nível sistêmico dos seres vivos e se perpetua por meio dos sistemas dos quais estes fazem parte. Neste sentido, Maturana e Varela $(1988,1997)$ defendem que a definição de qualquer ente autopoiético como uma máquina viva, pode assumir um caráter perigoso. Por isso, os autores subdividem os sistemas autopoiéticos em diversos níveis, capazes de distinguir a vida em sua essência, daqueles sistemas que dela são compostos.

Para os autores o ser vivo é um sistema autopoiético compreendido no domínio molecular. As entidades autopoiéticas fora do domínio molecular, também podem conter características dinâmicas de sistemas autopoiéticos em uma ordem superior, mas não podem ser consideradas vivas, em sua essência. Como exemplo pode-se tomar as células. Estas são sistemas autopoiéticos de primeira ordem, enquanto sistemas como os organismos, são sistemas autopoiéticos de segunda ordem, uma vez que são agregados de células. Já as culturas, sociedades e organizações humanas, podem ser vistas como sistemas autopoiéticos de terceira ordem, uma vez que agregam um conjunto de sistemas autopoiéticos de segunda ordem e assim por diante (MATURANA; VARELA, 1997).

Esta distinção entre sistemas de diferentes ordens se faz importante, pois os sistemas de ordem maior, como organismos e sociedades, não se tratam, essencialmente, de seres vivos e sim de sistemas que compartilham a mesma dinâmica com os mesmos. Por serem sistemas compostos de acoplamentos de máquinas vivas e, em alguns casos, máquinas não vivas, estes podem conter dinâmicas emergentes que não sejam contempladas pela dinâmica autopoiética - ver capítulo 2.5. Portanto, limitar o entendimento de um sistema de ordem maior, ao entendimento de um sistema de ordem menor, pode ocultar características chave que os tornem particulares (MATURANA; VARELA, 1997).

Neste sentido, Varela (1979) sugere que, ao invés de utilizar o termo autopoiese, extrapolado para sistemas de ordem superior, seja usado o termo "clausura operacional"75.

${ }^{75}$ Do inglês: "operational closure" 
Para o autor a clausura operacional é que seria a dinâmica básica que caracterizaria a classe de sistema à qual pertencem as máquinas autopoiéticas. Porém, diferente dos sistemas autopoiéticos - termo que, segundo o autor, deveria ficar restrito ao uso dos entes autopoiéticos de primeira ordem - a clausura operacional especifica apenas o fechamento operacional de um sistema aberto e não os processos de autoprodução, contemplados pela autopoiese.

Tendo por base a concepção de que as interações que ocorrem nos sistemas sociais se dão no nível da comunicação, Luhmann (1995) notou que os sistemas sociais não estariam sujeitos apenas aos preceitos da clausura operacional, propostos por Varela (1979). De certa forma, o sistema social tem suas fronteiras definidas por seus próprios valores e laços de confiança, estabelecidos entre os indivíduos que o formam. Neste cenário a comunicação entre um grupo de indivíduos se autoproduz dando origem a laços de realimentação que formam um conjunto de valores que, apesar das transformações, permanecem relativamente estáveis no decorrer do tempo. Portanto, no domínio da comunicação, os sócios-sistemas contemplam a capacidade de autoprodução que os tornam, em essência, autopoiéticos, de acordo com as definições de Humberto R. Maturana (LUHMANN, 1995). Assim, é possível transportar as ideias da teoria de Santiago para definir os sistemas sociais como entes dotados de autonomia e capacidade cognitiva própria.

\subsection{SIMBIOGÊNESE: OS ACOPLAMENTOS DOS SISTEMAS VIVOS}

Um importante aspecto dinâmico dos sistemas vivos é que, mesmo se tratando de sistemas abertos, com estruturas organizacionais fechadas, os organismos vivos tendem a se acoplar a outros sistemas vivos, tanto por acoplamento violento como por acoplamento não-violento. Capra (1983, p. 278) ressalta que "quanto mais alguém estuda o mundo vivo, mais percebe de que a tendência para a associação, para o estabelecimento de conexões, 
para a vida dentro de outros e para cooperar, é uma característica essencial dos organismos vivos." $^{\prime 76}$

\begin{abstract}
Abelhas e formigas, por exemplo, são incapazes de sobreviver isoladas, mas, em grande número, elas agem quase como células de um organismo complexo com uma inteligência coletiva e capacidade de adaptação muito superiores àquelas de cada um de seus membros. Semelhantes coordenações estreitas de atividades também ocorrem entre espécies diferentes, o que é conhecido como simbiose, e, mais uma vez, os sistemas vivos resultantes têm características de organismos isolados. (CAPRA, 2006, p. 44)
\end{abstract}

A simbiose é uma das mais notáveis formas de associação encontradas na natureza. "A simbiose, como o casamento, significa a vida em comum, nos bons e nos maus momentos; mas, enquanto o casamento é feito entre duas pessoas diferentes, a simbiose ocorre entre dois ou mais tipos diferentes de seres vivos." (MARGULIS; SAGAN, 2002, p. 132)

O estudo da simbiose tomou uma nova direção para a comunidade científica, a partir dos trabalhos da bióloga Lynn Margulis. Enquanto realizava um amplo estudo acerca das organelas, Margulis (1998) notou que as mitocôndrias ${ }^{77}$ se assemelhavam a uma estrutura bacteriana, dotada de suas próprias capacidades reprodutivas e de seu próprio DNA. Com base nesta constatação, Margulis (1998) concluiu que a mitocôndria se trata de um organismo dotado de sua própria autopoiese, que nutre um relacionamento tão próximo com as primeiras células procariontes ${ }^{78}$, que a vida de ambos se tornou impossível sem a presença um do outro.

Nesta sofisticada relação, os organismos dotados de tais organelas se tornaram mais eficientes ao processar o oxigênio e armazenar a energia dele derivada, enquanto o simbionte maior, ofereceu proteção e capacidade de locomoção a estas pequenas formas de vida que nele habitam. Margulis (2001) percebeu, então, que as organelas são subsistemas autônomos das células, que foram incorporados a partir de um acoplamento violento que a autora denomina de endosimbiose. Este processo pode ser visto em muitas formas de vida modernas. Ele pode ser hereditário, passar de geração para geração e se estabelecer a partir de uma forte relação e necessidade mútua entre os simbiontes.

Parcerias menos próximas, mas com profundas implicações, também podem ser vistas nas associações entre fungos e bactérias, para a formação dos liquens. Nelas, cada

\footnotetext{
${ }^{76}$ Do inglês: "The more one studies the living world the more one comes realize that tendency to associate, stablish links, live inside one another and cooperate is an essential characteristic of living organisms."

${ }^{77}$ As mitocôndrias são as pequenas usinas de força responsáveis por processar a respiração celular.

${ }^{78}$ Células procariontes são aquelas que não são dotadas de membranas isolando seu DNA.
} 
indivíduo sente a presença um do outro e estes estabelecem laços firmes e dependentes da história das relações entre ambos. Estas parcerias simbióticas entre reinos diferentes, podem desencadear resultados ainda mais profundos, como a transferências de genes fúngicos e bacterianos para o DNA das plantas, que ocorrem até os dias de hoje. Estes são exemplos extremos do tipo de aliança cruzada que constitui a vida na terra e o equilíbrio global (MARGULIS; SAGAN, 2002).

A partir destas observações Margulis e Sagan (2002) propuseram que:

a vida é o estranho fruto novo de indivíduos que evoluíram por simbiose, Nadando, conjugando-se, barganhando e dominando, as bactérias que viviam em estreita associação durante a era proterozóica deram origem a uma miríade de quimeras seres mistos, dos quais representamos uma fração minúscula de uma prole em expansão. Através de fusões corporais, esses seres díspares inventaram o sexo meiótico, a morte programada e uma complexa multicelularidade. (MARGULIS; SAGAN, 2002, p. 154)

Esta nova visão da evolução, trouxe a percepção de que a variedade incorporada pelos seres vivos microscópicos nem sempre foi obtida por acidente, como na visão Darwinista, e sim por meio da interação e aquisição de características através da simbiose. De acordo com os adeptos desta concepção, os múltiplos relacionamentos entre diversos espécimes microscópicos, inclusive relacionamentos tão estreitos e permanentes, como os endosimbiontes, são a base, tanto dos seres mais sofisticados do planeta - os eucariontes ${ }^{79}$ -, como do próprio sistema planetário (MARGULIS, 1998). Margulis (1998) denominou esta hipótese evolutiva, baseada na simbiose de longa duração, de simbiogênese. Para a autora, a simbiogênese mostra que a simbiose teve um papel crucial na evolução da vida na Terra, de certa forma mais importante do que a competição proposta pela visão Darwinista.

Neste cenário:

o ponto de vista da evolução como uma competição sangrenta recorrente entre indivíduos e espécies, uma distorção popular da noção de Darwin acerca da "sobrevivência dos mais aptos", se dissolve diante de uma nova visão de cooperação contínua, forte interação e dependência mútua entre formas de vida. A vida não assumiu o globo pelo combate, mas em rede. ${ }^{80}$ (MARGULIS; SAGAN, 1987, p. 30-31, tradução nossa)

\footnotetext{
${ }^{79}$ Eucariontes são seres dotados de células nucleadas.

${ }^{80}$ Do inglês: "[...] the view of evolution as chronic bloody competition among individuals and species, a popular distortion of Darwin's notion of "survival of the fittest," dissolves before a new view of continual cooperation, strong interaction, and mutual dependence among life forms. Life did not take over the globe by combat, but by networking."
} 
Neste sentido, Skår (2003) argumenta que a simbiogênese mostra que a competição é apenas uma fração de um processo maior que envolve, também, interações e trocas entre as unidades. Diante destas novas descobertas, o foco da biologia "[...] está se deslocando da evolução para a co-evolução - uma dança em andamento que procede por intermédio de uma sutil interação entre competição e cooperação, entre criação e mútua adaptação." (CAPRA, 2006, p. 182) Desse modo:

a teoria da simbiogênese implica uma mudança radical de percepção no pensamento evolutivo. Enquanto a teoria convencional concebe o desdobramento da vida como um processo no qual espécies apenas divergem uma da outra, Lynn Margulis alega que a formação de novas entidades, compostas por meio de simbiose de organismos antes independentes tem sido a mais poderosa e mais importante das forças evolutivas. (CAPRA, 2006, p. 185)

Apesar de a simbiogênese se consistir em uma poderosa força evolutiva, nem todo organismo consegue realizar este sofisticado processo com a mesma eficácia. De acordo com Margulis e Sagan (2002) as bactérias são melhores endosimbiontes do que seres mais complexos. Isso porque, estes organismos possuem uma individualidade limitada - não possuem sequer anticorpos - e, assim, podem aproveitar novas estruturas sem que estas sejam rejeitadas pela estrutura autopoiética que os constituem.

O repertório químico limitado destes organismos, também leva a uma tendência de complementaridade metabólica que, normalmente, implica em um elevado aumento da redundância, quando estes organismos vivem em conjunto (MARGULIS; SAGAN, 2002). Em síntese, as organizações mais simples tendem a tirar maior proveito e rejeitar menos os aspectos dinâmicos adicionados a sua estrutura básica, do que aquelas organizações mais complexas, onde a redundância embutida tende a combater o simbionte como uma perturbação à sua ordem.

Portanto, a concepção da evolução por meio da simbiogênese ilustra que "[...] a força motriz da evolução, de acordo com a nova teoria emergente, deve ser encontrada não em eventos casuais de mutações aleatórias, mas sim, na tendência inerente da vida para criar novidade, na emergência espontânea de complexidade e de ordem crescentes." (CAPRA, 2006, p. 182) Desse modo:

O reconhecimento da simbiose como força evolutiva importante tem profundas implicações filosóficas. Todos os organismos maiores, inclusive nós mesmos, são testemunhas vivas do fato de que práticas destrutivas não funcionam a longo prazo. No fim, os agressores sempre destroem a si mesmos, abrindo caminho para outros que sabem como cooperar e como progredir. A vida é muito menos uma 
luta competitiva pela sobrevivência do que um triunfo da cooperação e da criatividade. (CAPRA, 2006, p. 193)

\subsubsection{A simbiose entre máquinas autopoiéticas e alopoiéticas em sistemas complexos}

Uma das situações de maior magnitude, na qual a simbiose está envolvida, é aquela que envolve as dinâmicas de regulação do próprio planeta Terra. Tais implicações da simbiose ganharam força no início de 1965 quando James Lovelock e Dian Hitchcock foram convidados a realizar um estudo para a National Aeronautics and Space Administration (NASA), a respeito da viabilidade dos experimentos propostos para detecção de vida que seriam enviados a marte. Lovelock (2001) lembra que estes experimentos haviam sido projetados sob a concepção da vida terrestre o que, para o autor, era muito específico e poderia não condizer com as características da vida em outros planetas. Por meio de suas reflexões acerca do problema, o autor percebeu que os organismos vivos se caracterizam por capturar energia e matéria do ambiente e descartar resíduos (LOVELOCK, 2001).

Com base nesta percepção, Lovelock decidiu analisar as atmosferas dos planetas vizinhos à Terra em busca de inconsistências. Foi então que ele percebeu que a atmosfera destes planetas, diferia de forma dramática da atmosfera terrestre (LOVELOCK, 2000, 2001). Diferentemente de seus vizinhos, a Terra possui uma atmosfera composta por gases redutores e oxidantes, cuja coexistência não é esperada devido à forte tendência que estes gases possuem de reagirem entre si - ver gráfico 5 (LOVELOCK, 2000, 2001; MARGULIS; SAGAN, 2002). 


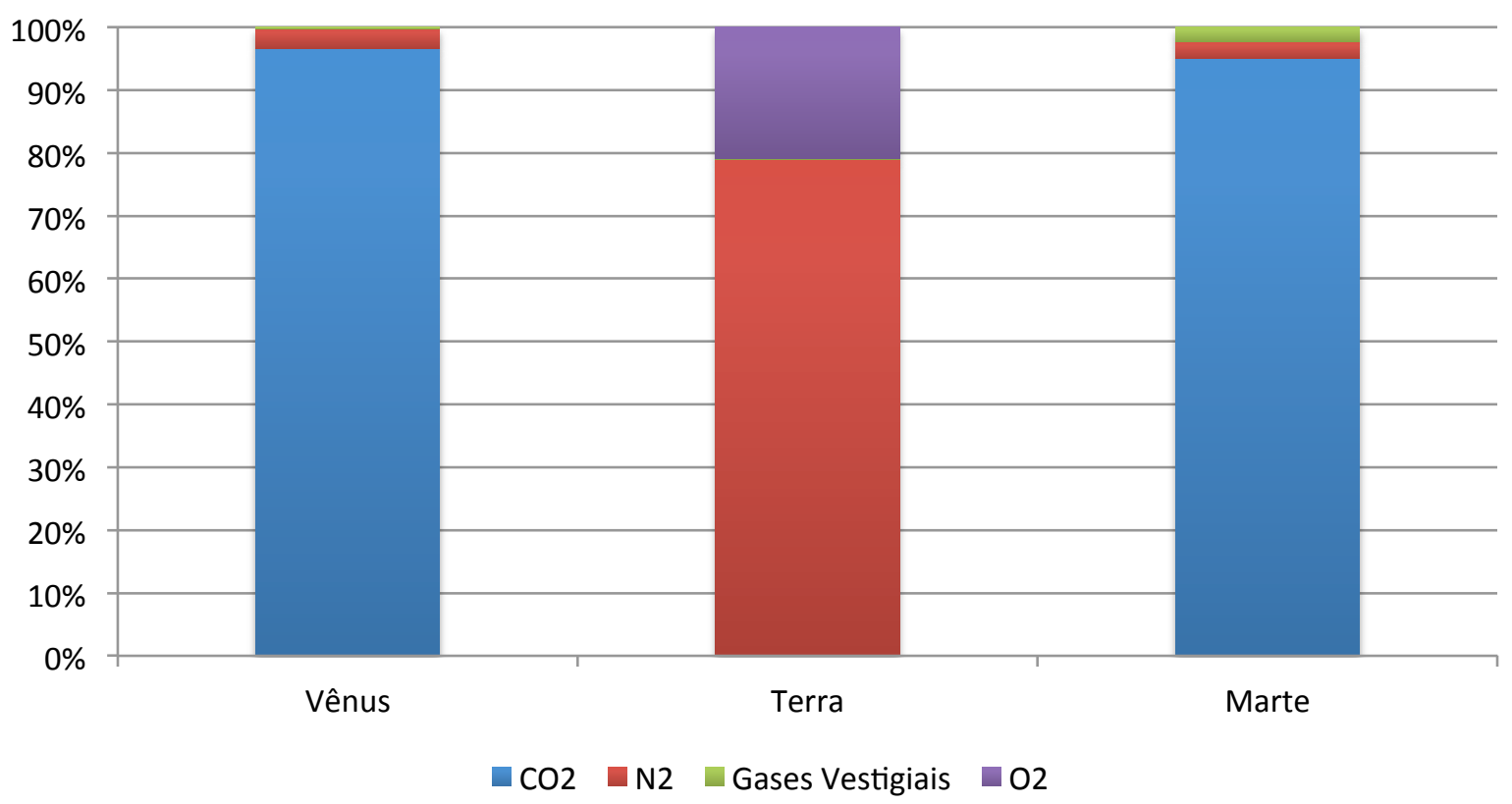

Gráfico 5 - Comparação atmosférica da Terra com seus dois vizinhos planetários.

Adaptado de: Margulis e Sagan (2002, p. 34)

Estarrecido com esta constatação, Lovelock procurou compreender como uma atmosfera composta por gases altamente reativos, como a da Terra, poderia permanecer estável no decorrer do tempo, mesmo diante de condições tão distantes do equilíbrio. Ao refletir sobre esta constatação, o autor propôs uma hipótese onde a Terra seria uma estrutura muito particular que agiria como um grande sistema homeostático, onde a biosfera atuaria aplicando feedback negativo para controlar as condições para a sua própria existência (LOVELOCK, 2000). Nesta concepção, “[...] o ar poderia ser considerado como uma pele de gato ou o revestimento de um ninho de vespas: sem vida, mas feitos por seres vivos para suportar um dado ambiente." (LOVELOCK, 2000; 2001, p. 81) Lovelock denominou esta controversa hipótese de hipótese de Gaia, em homenagem a deusa grega que leva o mesmo nome (LOVELOCK, 2000).

De acordo com a hipótese de Gaia a Terra seria controlada pela vida, o ecossistema regularia o planeta, compensando, inclusive, o aquecimento gradual de nosso sol em uma robusta teia de interações, onde a evolução e os distúrbios externos - ruídos - contribuem para os saltos qualitativos do sistema. Ou seja, para Lovelock a Terra possuiria um comportamento autopoiético, típico de um organismo vivo (LOVELOCK, 2001). Esta ideia revolucionária provocou grandes controvérsias. Margulis e Sagan (2002, p. 63) lembram que Lovelock não só "[...] teve que mostrar que a Terra se mantinha como um corpo vivo, como 
também precisou superar o preconceito de que chamar de viva essa "coisa" não era ciência, mas uma personificação poética."

Lovelock se associou, então, a Lynn Margulis com o objetivo de aprimorar este modelo, por meio do mapeamento dos aspectos deste grande sistema planetário. Juntos, Lovelock e Margulis “[...] foram capazes de, gradualmente, identificar uma complexa rede de laços de realimentação, a qual - conforme propuseram como hipótese - criaria a autoregulação do sistema planetário." (CAPRA, 2006, p. 93)

O aspecto de destaque desses laços de realimentação está no fato de que ligam
conjuntamente sistemas vivos e não-vivos. Não podemos mais pensar nas rochas,
nos animais e nas plantas como estando separados uns dos outros. A teoria de Gaia
mostra que há um estreito entrosamento entre as partes vivas do planeta -
plantas, microrganismos e animais - e suas partes não-vivas - rochas, oceanos e
atmosfera. (CAPRA, 2006, p. 93)

Contudo, a hipótese de Gaia só veio a assumir a condição de teoria, após uma bem sucedida simulação matemática, proposta por Watson e Lovelock (1983), denominada "mundo das margaridas" 81 . Os autores partiram do pressuposto básico de que a autoregulação da temperatura seria uma propriedade emergente de um planta habitado. Então eles criaram um mundo hipotético, úmido e homogêneo, próximo a uma estrela que estaria se aquecendo gradualmente, como o nosso sol. Para testar sua hipótese Watson e Lovelock (1983) inseriram, neste suposto mundo, duas espécies de margaridas - brancas e negras que cresceriam somente em determinadas faixas de temperatura. As margaridas brancas tinham a propriedade de refletir o calor, enquanto as negras apresentavam a propriedade de absorvê-lo.

Os resultados encontrados por Watson e Lovelock (1983) mostraram que a partir do momento em que a temperatura do planeta atingia o ponto propício para o desenvolvimento da vida, as margaridas negras se proliferaram, devido sua habilidade de reter calor. Conforme o sol continuava se aquecendo as margaridas brancas se tornaram dominantes, mantendo um bolsão de temperatura constante durante um determinado período de tempo. Portanto, o planeta hipotético dos autores se comportou como uma estrutura homeostática. capaz de se autorregular, por meio da vida, até que a temperatura atingisse o ponto de ruptura do sistema.

${ }^{81}$ Do inglês: "Daisyworld" 
Posteriormente, Lenton (1998) aprimorou o mundo das margaridas para provar a hipótese de que os processos de Gaia vão além dos biológicos e envolvem complexos sistemas abióticos e evolutivos, em acoplamento. O autor se baseou no modelo original Watson e Lovelock (1983), mas adicionou ao mundo das margaridas a presença de nuvens. Lenton (1998) observou que, conforme as margaridas negras se propagavam, as nuvens se formavam bloqueando a passagem do sol. O autor também notou que ao adicionar os processos abióticos, as margaridas negras deixaram de competir com as brancas, pois as nuvens compensavam seu aquecimento. Deste modo, a introdução dos processos abióticos reduziu a competição no mundo das margaridas.

Mas o trabalho de Lenton (1998) não parou por ai. O autor foi além das proposições iniciais da hipótese de Gaia e investigou sua relação com a evolução e a seleção natural. Ele adicionou ao mundo das margaridas, um componente de mutação aleatória com igual probabilidade de mutação, visando ajudar ou prejudicar o ambiente. Neste segundo modelo o autor pretendia analisar se a evolução das margaridas, a partir de um tom igual ao do ambiente, colaboraria ou não para o equilíbrio deste planeta hipotético. Mais uma vez a simulação mostrou que o mundo das margaridas tendeu ao equilíbrio.

Lenton (1998) também percebeu, por meio desta simulação, duas importantes características deste complexo sistema. A primeira é que o autor constatou que os organismos que tendem a se perpetuar em um grande sistema regido por acoplamentos, como estes, são aqueles que tendem a estabelecer feedback com o meio, de forma a mantêlo de acordo com suas condições de sobrevivência. A segunda característica dinâmica encontrada por Lenton (1998) é que em um sistema de nichos, como o mundo das margaridas, uma fragmentação do ambiente ou um dano provocado a uma região, pode provocar o colapso de todo o sistema. Com estas características, o autor notou que em sistemas divididos em múltiplos níveis, como no ecossistema terrestre, um problema localizado pode não significar o colapso de todo o sistema, já que as espécies dos outros nichos podem suprir as perdas da área atingida. Com isso, Lenton (1998) concluiu que neste tipo de sistema a competição e seleção natural são necessárias para a manutenção do equilíbrio planetário.

Destarte, os trabalhos dos adeptos da teoria de Gaia mostraram uma situação onde o acoplamento entre sistemas alopoiéticos e sistemas autopoiéticos podem constituir uma dinâmica autopoiética, onde a sobrevivência do próprio sistema está ligada a manutenção 
de laços de feedback auto-reguladores e auto-construtivos, por parte de seus componentes. Nestas condições a os componentes do sistema são os responsáveis pela manutenção do próprio ambiente que os sustenta e, portanto, nutrem um forte relacionamento simbiótico com o mesmo.

\subsection{APRESENTAÇÃO DOS RESULTADOS}

No âmbito da Administração, as organizações são "entidades que capacitam a sociedade a buscar realizações que não podem ser atingidas por pessoas atuando individualmente." (GIBSON et al., 2006, p. 5) De acordo com Bauer (1999) este tipo de estrutura foi tratada por muito tempo como uma máquina determinada. Tal percepção do autor é visível nas concepções das escolas de pensamento estratégico prescritivas, descritas por Mintzberg, Ahlstrand e Lampel (1998), onde as estratégicas são deliberadas por um único ente e seguidas como programas pela organização.

Bauer (1999), ressalta que diante das perspectivas de cenários cada vez mais complexos, a organização precisa ser compreendida por meio de visões que contemplem as instabilidades do meio e da própria organização. O autor se concentrou, então, na concepção da cultura - como fenômeno social responsável pela identidade organizacional para descrever o comportamento das organizações sob os princípios da auto-organização e da autopoiese.

Uma vez que a concepção de cultura se trata de uma concepção social, as ideias de Bauer (1999) se mostram válidas, pois, conforme visto nos trabalhos de autores como Capra (1983, 2006), Luhmann (1995), Morin (2007b, c, a) - ver capítulo 5.3, a auto-organização e a autopoiese são descrições análogas a dinâmica deste tipo de sistema, ao passo que estes também sustentam sua identidade por meio de sua auto-organização. Contudo, conforme lembram Caravantes, Panno e Kloeckner (2005, p. 153) é preciso levar em conta que 
organização é um sistema sociotécnico estruturado onde "[...] os subsistemas técnicos e social se inter-relacionam, influenciam-se mutuamente e interdependem. Daí não haver como definir a organização apenas como sistema técnico ou apenas como sistema social [...]". Portanto, em certos aspectos, a excelente abordagem de Bauer (1999) se mostra incompleta já que não contempla as unidades e as relações entre o sistema social e os subsistemas técnicos, presentes em toda organização.

Esta relação que constrói a organização como um sistema sociotécnico, citada por Caravantes, Panno e Kloeckner (2005), também se encontra presente na descrição da essência primeira do problema estratégico, mostrada no capítulo 4.1. Neste sentido, os subsistemas técnicos - formados pela estrutura física e sua interação com os seres humanos - podem ser entendidos como máquinas do tipo alopoiéticas, já que estas partes da organização são criadas e organizadas por meio da determinação dos fatores humanos da mesma.

A programação deste sistema sociotécnico decorre das ações coletivas da organização que, conforme ilustra o processo estratégico descrito por Mintzberg, Ahlstrand e Lampel (1998) e Mintzberg e Lampel (1999), pode ter origem tanto emergente, quanto deliberada, e se origina com base na cultura, na política e no aprendizado. Uma vez que Maturana e Varela $(1988)$ Capra $(1983,2006)$, Luhmann (1995) e Bauer (1999) propõem que estes três fatores apresentam relações que lhes permitem ser explicadas por meio dos princípios autopoiéticos e da teoria de Santiago, então é possível se apropriar das conclusões de Bauer (1999) para descrever os subsistemas sociais da organização, por meio dos princípios autopoiéticos.

Com base nestas concepções é possível construir a transição do quadro geral da essência primeira da organização - ver figura 14 no capítulo 4.1 - para uma perspectiva onde ela é vista como um acoplamento entre um sistema análogo a uma máquina autopoiética e outro análogo a uma máquina alopoiética, cujo programa é fornecido pela máquina autopoiética - ver figura 20. 


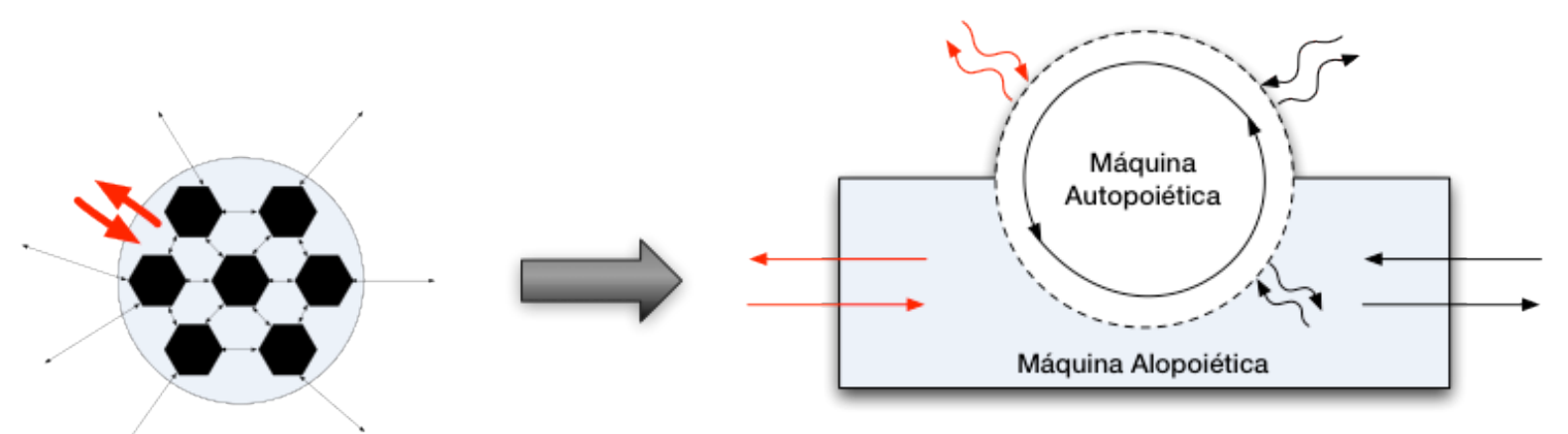

Figura 20 - Conversão da essência primeira de uma organização em um diagrama sintético classificado Fonte: Elaborada pelo autor

Nesta máquina, a rede social da organização é dada pela máquina autopoiética, devido à sua auto-referência. A estrutura técnica - dada pela fronteira do círculo azul e sua integração com os humanos -, é representada pela máquina alopoiética. As perturbações e resíduos trocados entre a máquina autopoiética, o meio ambiente e o meio social são dadas pelas setas onduladas vermelhas e pretas, respectivamente. As entradas e saídas da máquina alopoiética em relação ao meio são dadas pelas setas em linha. Já as relações entre as duas máquinas se dão por meio de perturbações e resíduos trocados entre ambas. Desse modo, é possível se apropriar das palavras de Morin (2007c) e afirmar que nas organizações "a complexidade surge neste enunciado: produz coisas e se autoproduz ao mesmo tempo; o produtor é seu próprio produto." (MORIN, 2007c, p. 86)

Tal síntese da essência primeira da dinâmica organizacional, também estaria contemplada na percepção de Morin (2007c), para quem uma organização empresarial:

[...] produz objetos ou serviços, coisas que se tornam exteriores a ela e entram no
universo do consumo. Limitar-se a uma visão heteroprodutora da empresa seria
insuficiente. Porque ao produzir coisas e serviços, a empresa, ao mesmo tempo, se
autoproduz. Isto quer dizer que ela produz todos os elementos necessários para
sua própria sobrevivência e para sua própria organização. Ao organizar a produção
de objetos e serviços, ela se auto-organiza, se auto-entretém, se necessário se
autoconserta, e se as coisas vão bem, se autodesenvolve ao desenvolver sua
produção. (MORIN, 2007c, p. 86 )

Nesta descrição a ação, ou seja a estratégia, atua como o programa executado pela organização, porém este programa não é um programa deliberado por um ente isolado, ele é dado pelos resíduos da máquina autopoiética que, em última instância, derivam de sua configuração e de sua estrutura interna auto-organizante. Em outras palavras, a estratégia é, em essência, um programa autorreferente no qual a deliberação de um ente, consiste em uma pequena parcela da estratégia que pode, inclusive, ser anulada pela dinâmica de auto- 
organização e a capacidade regenerativa da máquina autopoiética. Esta ideia de programa autorreferente seria, em última instância, capaz de unificar as visões de estratégia emergente e deliberada, uma vez que dela emergem todas as particularidades e dinâmicas destas concepções.

Contudo, há de se ressaltar que os estudos acerca da teoria de Gaia mostram que os acoplamentos entre sistemas autopoiéticos e alopoiéticos podem se configurar como estruturas autopoiéticas. Neste sentido, a teoria de Gaia e a simbiogênese - ver capítulo 5.4 - permitem emprestar, por analogia, o termo simbiose para dar nome à estrutura de acoplamento íntimo entre duas máquinas de natureza distintas. Uma vez que a fronteira da organização é dada por um conjunto de regras básicas, que sustentam suas fronteiras e sua autopoiese, pode-se dizer que na organização isso também ocorre.

Entretanto, a parte alopoiética da organização é finalista, visa atender a determinações da máquina autopoiética, e esta última se trata de um dispositivo autorreferente e, como tal, pode alterar seus próprios comportamentos e programas, além da construção e finalidade do sistema alopoiético ao qual se acopla. Sob esta concepção, as organizações não podem ser tratadas nem como entes meramente autopoiéticos - autoorganizantes e autorreferentes - nem como entes alopoiéticos, como preveem as escolas clássicas da estratégia - ver seção 3. Como um acoplamento entre estes dois tipos de sistemas, a organização apresenta particularidades intrínsecas a cada parte do sistema, das quais emergem as particularidades gerais, fruto do acoplamento entre eles.

O sistema autorreferente que emerge a partir destas duas dinâmicas distintas autopoiese e alopoiese -, é composto por uma ampla gama de componentes e interações que são perturbados por laços complexos de realimentação entre a organização e o meio externo, onde também há auto-referência. Desse modo, inicialmente a estratégia pode até preceder a estrutura à qual vai se acoplar, conforme previsto pelas escolas prescritivas. Contudo, decorrido um determinado período de tempo, se estabelece uma interdependência entre ambas, onde a estrutura estabelece limites de adaptabilidade da cultura que, até certo ponto, dependente da estrutura. Portanto, o problema estratégico precisa ser abordado pela alta gestão, tanto pelas particularidades de cada uma das máquinas que as formam, como pela dinâmica de sua totalidade.

Neste contexto, o processo estratégico proposto por Mintzberg, Ahlstrand e Lampel (1998) e Mintzberg e Lampel (1999), se apresenta como uma contribuição importante, pois 
assimila, simultaneamente, os aspectos do controle e do aprendizado organizacional - ver capítulo 3.2. Estes aspectos representam, respectivamente, a capacidade de programação das atividades da máquina alopoiética e a auto-organização evolutiva da máquina autopoiética da organização. Portanto, os componentes do processo estratégico dos autores, olham para partes distintas de um programa autopoiético, cuja influência estabelece a dinâmica do componente alopoiético a ele conectado.

Devido ao fato de os seres humanos serem os elos de acoplamento entre os tecnosistemas e os aspectos inerentes à mente e a cultura, então a fronteira que distingue a parte técnica e a parte autorreferente da organização se encontra no interior de cada um de seus colaboradores. Deste modo, esta descrição da organização padece do problema clássico do pensamento complexo, acerca das dificuldades em se estabelecer as fronteiras exatas entre uma máquina e outra - ver capítulo 2.5. Contudo, esta concepção permite aos pesquisadores da área tratarem o problema da estratégia mediante a perspectiva da interação entre sistemas distintos, capazes de comportamentos particulares que, em última instância, culminam com a emergência de um comportamento integrado.

Neste ponto se faz pertinente retomar as antigas discussões de Michael Porter e Henry Mintzberg acerca do que é estratégia - ver capítulo 3.1. Olhando sob a perspectiva da organização como a simbiose entre máquinas distintas, Porter (1996) estava, até certo ponto, correto ao afirmar que eficácia operacional não é estratégia. Assim como previra o autor, a concepção da organização como um conjunto de simbiontes, mostra que a eficácia operacional está vinculada aos seus tecnosistemas e sob esta percepção a máquina alopoiética, apesar de ser o meio pelo qual a ação se realiza, só opera por meio da determinação de um programa autopoiético. Em outras palavras, a estratégia como ação, emerge dos sócios-sistemas da organização e não de seus tecnosistemas, cuja eficácia acaba por ser uma determinação dos anteriores, conforme descrevera Porter (1996).

Contudo, esta compreensão só é válida a partir de uma apreensão fragmentadora, pois como uma totalidade a organização age por meio de uma dinâmica autopoiética que integra sua máquina alopoiética e seu sistema autorreferente. Deste modo, vista por meio de um panorama geral, a estratégia emerge a partir desta grande máquina autopoiética, oriunda da simbiose entre estas máquinas. Portanto, ao olhar o sistema como um todo, as estratégias são de fato padrões de comportamento, que emergem de sistemas 
autorreferentes como a cognição, a cultura e o aprendizado organizacional, que são reproduzidos pelas atividades técnicas da empresa, conforme previra Mintzberg (1987b).

Este entendimento da organização é capaz de contemplar, simultaneamente, visões até então vistas como antagônicas. Mintzberg (1987b) enxergou um componente crucial da estratégia sob a concepção da empresa como uma unidade integrada em múltiplos processos. Por outro lado, Porter (1996) percebeu, por meio da fragmentação dos processos e da cadeia de valor - que representa as operações dos tecnosistemas da organização -, que a eficácia operacional decorre da programação das atividades técnicas da organização, por meio de sua máquina autopoiética. Mintzberg (1987b) e Porter (1996) observaram, então, o problema de níveis sistêmicos distintos.

Portanto, esta compreensão da organização leva à uma visão conciliadora da estratégia, que permite reconhecer que os constructos acerca do problema, realizados até então, não são conflitantes, como aparentam em alguns casos. Na verdade, eles são formulações que permitem à organização estruturar suas decisões, sem negligenciar nem as partes e tampouco o todo, ao passo que levam em conta as características dos mais variados níveis sistêmicos que a compõem.

Diante de um sistema autopoiético de controle estratégico, como o mostrado, a aquisição de novas pessoas pode se configurar de maneira análoga à simbiogênese - ver capítulo 5.4 -, já que consiste no processo de incorporação de um ente autopoiético, por uma outra organização de dinâmica semelhante. Neste contexto, tal aquisição de material humano agiria conforme os preceitos da endosimbiose, onde o acoplamento insere novas habilidades na organização, aumentando sua variedade e redundância. Portanto, esta concepção da máquina autopoiética faz jus a conclusão de Pascale $(2002$, p. 119) de que para as organizações "[...] as pessoas são cromossomos, o material genético capaz de criar variedade." Neste caso, é preciso que haja um cuidado especial para que a variedade interna não seja combatida, o que fragilizaria a máquina autopoiética da estratégia.

Neste sentido, Sardar e Abrams (1999, p. 46, tradução nossa) ressaltam que "o equivalente cultural dos atratores seriam os chefes, as tribos, os estados e aquilo que nos dá identidade, como a religião, as classes e as visões de mundo." ${ }^{82}$ Neste contexto, adicionar, remover ou mover indivíduos ou unidades dentro de uma organização ou, até mesmo,

\footnotetext{
${ }^{82}$ Do inglês: "The cultural equivalent of attractors would be chiefs, tribes, states and what gives us identity, like religion, class and worldviews."
} 
proporcionar cursos ou incentivar associações, também pode provocar rupturas irreversíveis na dinâmica dos processos autopoiéticos da organização.

Estas transformações podem ser tanto positivas quanto negativas, mas a dinâmica dos sistemas dissipativos - ver capítulo 5.2 - mostra que ao alterar um atrator, a organização pode promover um ponto de bifurcação, o que impossibilitaria a mesma de restabelecer a dinâmica inicial do sistema. Neste sentido, Goulielmos (2005) destaca a importância de se identificar aquilo que denominou de "atratores humanos" ${ }^{83}$. O autor lembra que a estrutura da organização deve ser pensada a partir destes indivíduos e não em uma hierarquia forçada sobre indivíduos que não tenham esta capacidade de criar bacias de atração. Esta abordagem se mostra sinérgica com a concepção de uma organização simbiótica. Neste contexto, a preocupação do autor também pode ser expandida não só para a hierarquia, como para todos os processos da organização.

Portanto, ao cultivar variedade é necessário que os gestores se atenham a identidade da organização, mesmo frente a processos de mudança radical. Uma vez que esta identidade é mantida por uma máquina autorreferente, é importante que o estrategista perceba que esta manutenção da identidade não diz respeito a programar ações, e sim à manutenção e à comunicação claras da missão e da visão da organização, assim como a manutenção de sua cultura, por meio da conservação das relações chave do sistema.

Esta constatação trás implicações importantes sobre processos que envolvam a aquisição de novas características para a organização. Em uma perspectiva competitiva, como a adotada pelas escolas clássicas, as estratégias de integração, como as fusões e aquisições, se mostram eficientes para adquirir novas fatias de mercado, aumentar a receita e promover ganho de escala, além de auxiliar a eliminar parte da concorrência (WRIGHT; KROLL; PARNELL, 2007). Contudo, os conceitos da simbiose, mostram que os acoplamentos entre duas organizações distintas, também podem criar novas bacias de atração que podem produzir significativas implicações sobre a dinâmica dos sócios-sistemas envolvidos.

Este tipo de acoplamento se desenvolve alterando as estruturas de ambas as organizações, ou seja, consiste em um acoplamento violento equivalente à endosimbiose ver capítulos 5.1 e 5.4. A cultura organizacional, como uma máquina autopoiética, se apresenta como um dispositivo com limites de regeneração definidos. Uma perturbação em

\footnotetext{
${ }^{83}$ Do inglês: "human-attractors".
} 
grande escala da cultura, como a provocada por uma fusão ou uma aquisição, pode desencadear um salto qualitativo para um patamar indesejado, ou até mesmo uma ruptura da autopoiese da mesma. Portanto, este tipo de integração pode culminar com a degradação ou até mesmo com o colapso da organização.

Neste sentido, a individualidade da organização assume um papel importante para determinar os riscos deste tipo de processo. A teoria da simbiogênese mostra que os acoplamentos violentos, como a endosimbiose, são de fato um instrumento poderoso para aquisição de novas características. Contudo, este tipo de acoplamento tende a ter maior sucesso quando as estruturas são simples e a individualidade da organização é limitada entende-se por individualidade limitada uma cultura pouco enraizada -, de tal forma que não haja um comportamento destrutivo entre as unidades incorporadas. Quando as organizações fundidas apresentam individualidades robustas, uma associação deste tipo pode implicar em rupturas pouco funcionais, onde as individualidades de cada organização agem como anticorpos, fazendo com que estas aniquilem ou prejudiquem a autopoiese uma da outra - ver capítulo 5.4 .

Neste último caso os exemplos da simbiose no mundo natural, mostram que as parcerias e as abordagens cooperativas, entre organismos distintos e operando por meio de associações não definitivas, podem apresentar benefícios em relação às abordagens competitivas e de endosimbiose definitiva. Tal processo possibilita uma troca em menor escala das características de cada organização. Entretanto estas associações não-violentas também implicam em uma menor interferência na dinâmica autopoiética da organização, o que minimiza o riscos de colapso em seu sistema estratégico.

Uma outra implicação percebida diante desta dinâmica interna das organizações, tem origem em uma associação das teorias dos sistemas dissipativos e da autopoiese - ver capítulos 5.2 e 5.3. Os estudos destes sistemas mostram que estes precisam de fluxos de energia mínimos para que suas organizações não entrem em colapso. Uma queda abrupta no fluxo de energia, como uma crise, pode significar a morte de uma organização muito complexa. Neste cenário as organizações menores seriam mais aptas a enfrentar momentos de crise, por precisarem de menos recursos para sustentarem sua estrutura. Entretanto, em bolsões de abundância de recursos, as organizações mais complexas tendem a possuir maior redundância e, com isso, estariam mais aptas a enfrentar rupturas que não envolvessem reduções na oferta de recursos. Neste cenário, as organizações com maior chance de 
sobreviver, em ambas as condições, são aquelas que são estruturalmente pequenas e simples, para perdurarem em momentos de crises de recursos, mas apresentem capacidade de se associar em estreita simbiose com outras organizações, sustentando sua independência e compartilhando sua variedade, assim como fazem os liquens - ver capítulo 5.4 .

Destes princípios também deriva uma outra propriedade emerge das organizações empresariais. Uma vez que estas dependem de um fluxo de energia constante para sustentar sua organização, esta dinâmica exige que haja uma troca forçada, onde o sistema se utiliza do excedente de matéria e energia do meio que o cerca - que em última instância envolve também valores econômicos - para sustentar sua organização - ver capítulos 5.2 e 5.3. Tal percepção também é encontrara na essência primeira do problema estratégico, onde as fronteiras da organização são permeáveis às interações entre humanos e ao trânsito de recursos do meio - ver capítulo 4.1. Neste sentido Morin (2007c, p. 87) ressalta que é preciso que a empresa seja "[...] colocada num ambiente externo que por sua vez integra um sistema ecoorganizado ou ecossistema."

Pode-se dizer, então, que as organizações vivem em uma dinâmica na qual se portam como endosimbiontes do sistema social humano - que representa seu ambiente externo ao mesmo tempo que este sistema atua como subsistema de uma máquina maior, representada pelo ecossistema. O ecossistema, por sua vez, reside em um sistema ainda mais amplo, derivado do acoplamento deste último com a matéria não-viva do sistema planetário, que Lovelock $(2000,2001)$ denominou de Gaia - ver capítulo 5.4.1.

Normalmente, esta dinâmica de trocas tem por objetivo processar matéria, energia e informação de "Gaia", para o uso do sócio-sistema humano. Neste contexto, as organizações nutrem uma forte analogia com as mitocôndrias - ver capítulo 5.4. Apesar de serem endosimbiontes de um sistema maior, estas organelas processam recursos do meio externo, com objetivo de sustentar o organismo do qual fazem parte. Neste sentido, é importante ressaltar que este processamento de recursos gera resíduos que são excretados para o ambiente, o que contribui para a desordem do mesmo. Com base nestas constatações e na essência primeira do problema estratégico, percebe-se que a dinâmica dos aspectos internos e externos à organização ocorrem, simultaneamente, de acordo com o que é expressado na figura 21. 


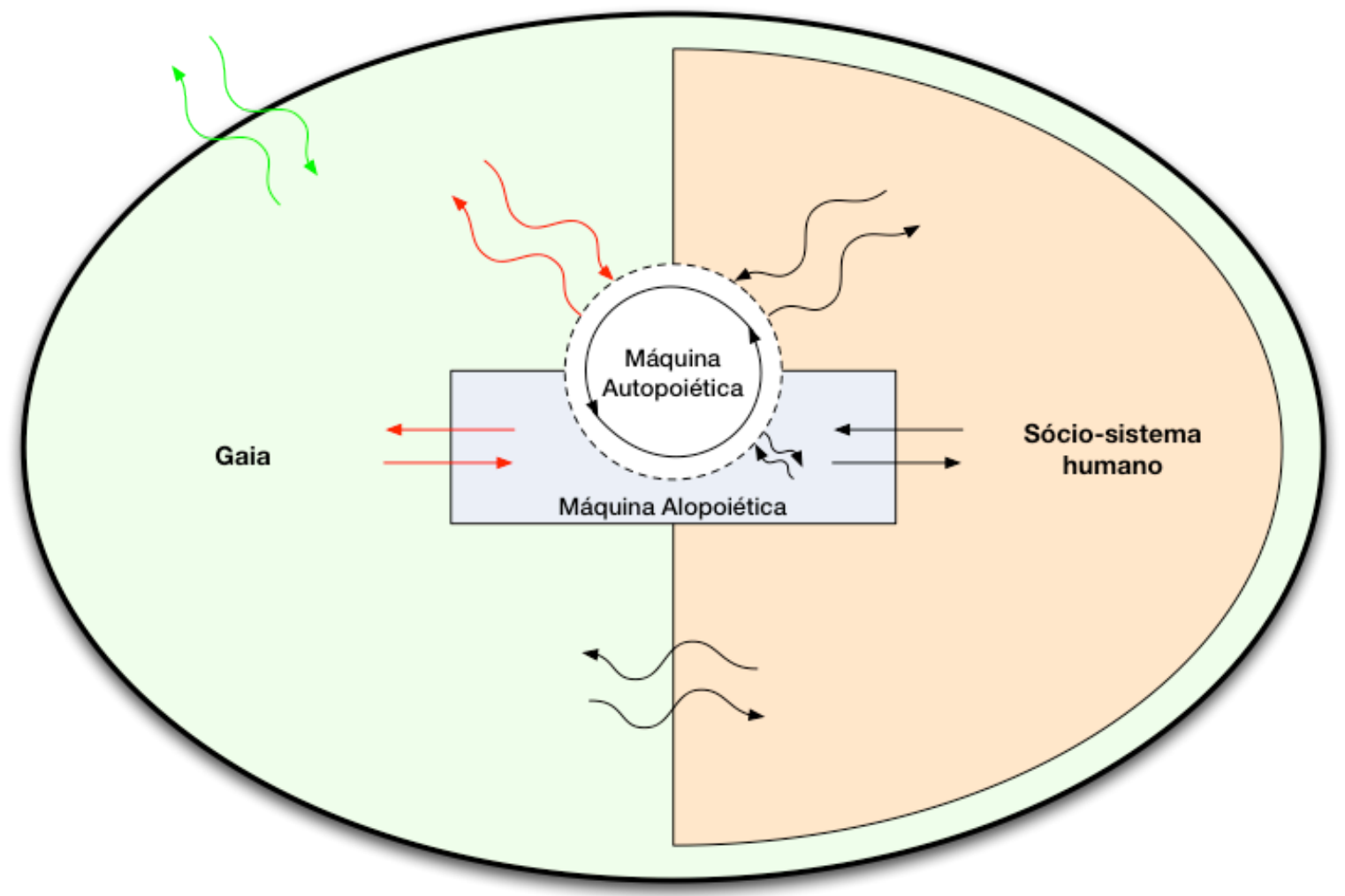

Figura 21 - Diagrama esquemático da dinâmica do problema estratégico.

Fonte: Elaborada pelo autor

Esta dinâmica mostra que a máquina alopoiética da organização se acopla a Gaia e ao sócio-sistema humano, com o objetivo de realizar trocas com ambos para permitir que os excedentes destas interações sejam suficientes garantir o fluxo de recursos necessário para sustentar a máquina autopoiética da organização. No âmbito externo, a máquina autopoiética - responsável pela programação autorreferente da organização - é influenciada pelo fluxo de perturbações provocadas por Gaia e pelo sócio-sistema humano, ao passo que também influencia tais sistemas por meio de seus resíduos sociais e materiais. Neste contexto, outras organizações e seres humanos individuais, também ligam o sóciosistema humano a Gaia fechando um complexo laço de realimentação. Por fim, a complexidade se amplia ao passo que Gaia também é um sistema aberto, distante do equilíbrio, onde o fluxo de energia solar se constitui em um atributo importante para a manutenção de sua ordem interna.

Diante da concepção de que as ações da organização afetam diretamente o meio, a estratégia consiste em uma entidade cuja organização autopoiética possui vigorosos laços de realimentação, tanto Gaia como com o sócio-sistema humano - ver figura 22. Portanto, a estratégia afeta estes sistemas da mesma forma que estes a afetam. Neste contexto, é 
importante ressaltar que, tanto o sócio-sistema humano como Gaia são entidades autopoiéticas, dotadas de sua própria dinâmica e identidade - ver capítulos 5.3 e 5.4. Portanto, a organização atua como um simbionte e a ruptura da autopoiese de qualquer um dos sistemas a ela acoplados, também levaria a organização a um colapso inevitável. Mesmo um salto qualitativo em um destes sistemas - como as mudanças ocorridas nos sistemas produtivos no decorrer da história humana -, pode provocar uma alteração indesejada nos padrões de perturbações e entradas da organização. Tais alterações também podem levar a organização a uma alteração indesejada ou até mesmo à desintegração de sua estrutura autopoiética.

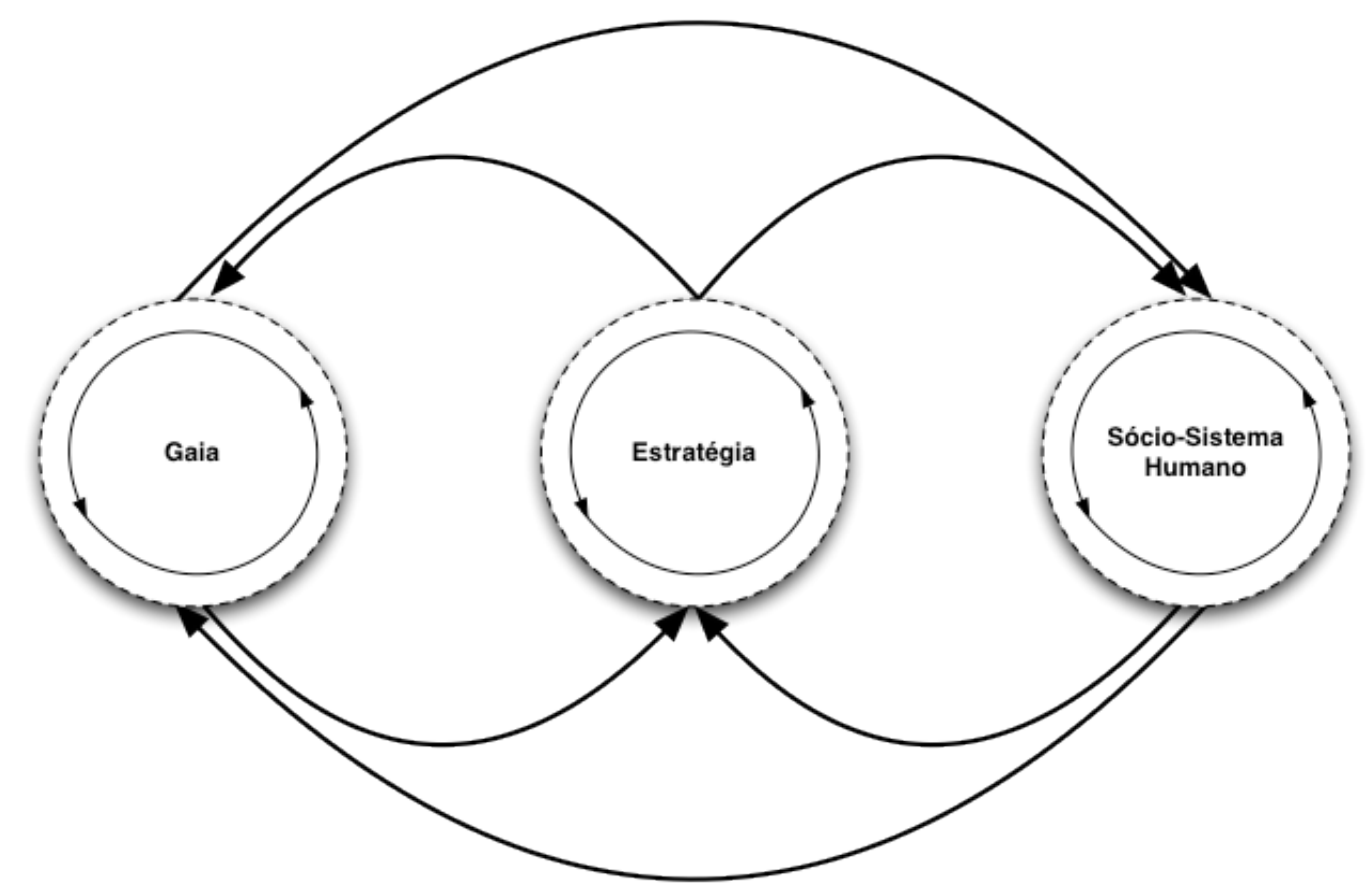

Figura 22 - Laços de realimentação entre os sistemas externos e a estratégia das organizações Fonte: Elaborada pelo autor

Desse modo, a concepção da dinâmica dos aspectos internos e externos do problema estratégico, como um problema relacionado à simbiose entre máquinas com características autopoiéticas, remete a uma concepção onde a estratégia diz respeito a acoplamentos. Realizar estratégias consiste, portanto, em configurar acoplamentos entre os aspectos internos da organização e os aspectos externos a esta. Neste sentido, onze variáveis, que podem ser vistas no quadro 12 , assumem especial importância para o gerenciamento da dinâmica da máquina autopoiética, responsável pela estratégia da organização. 


\section{Variáveis do problema estratégico}

1. Acoplamentos internos da máquina Autopoiética da organização;

2. Acoplamentos internos da máquina Alopoiética da organização;

3. Acoplamentos internos do sócio-sistema humano;

4. Acoplamentos Internos de Gaia;

5. Acoplamento entre máquina Autopoiética e máquina Alopoiética da organização;

6. Acoplamento entre a máquina Autopoiética da organização e o sócio-sistema humano;

7. Acoplamento entre a máquina Alopoiética da organização e o sócio-sistema humano;

8. Acoplamento entre a máquina Autopoiética da organização e Gaia;

9. Acoplamento entre a máquina Alopoiética da organização e Gaia;

10. Acoplamento entre Gaia e o sócio-sistema humano;

11. Acoplamento entre Gaia e o restante do universo.

Quadro 12 - Variáveis do problema estratégico

Fonte: Elaborado pelo autor

Esta concepção de estratégia trás profundas implicações sobre a forma com a qual ela precisa ser abordada. Conforme destacam as simulações de Varela, Maturana e Uribe (1974) a sobrevivência do meio, como ente autopoiético, só será possível se a taxa de desintegração, provocada por seus subsistemas, for menor do que sua capacidade de regeneração - ver capítulo 5.3. Como as organizações importam a ordem de sua máquina autopoiética dos excedentes obtidos por sua interação com o meio, elas tendem a prosperar enquanto o meio for capaz de se regenerar para lhes fornecer ordem.

Quando o meio perde a capacidade de fornecer entropia negativa para a organização, seu sistema social tende a sucumbir frente à desordem - ver capítulo 5.2 e 5.3. Uma vez que a sobrevivência do sócio-sistema humano depende tanto do processamento de recursos das organizações, quanto da sobrevivência de Gaia, então se torna fundamental que as estratégias de acoplamento da organização com o meio, levem em consideração a sobrevivência de todos os sistemas aos quais esta se encontre acoplada. Em última instância, é da sobrevivência destes que deriva sobrevivência de sua própria organização.

Além disso, as simulações do "mundo das margaridas", realizadas por Lenton (1998) - ver capítulo 5.4 - mostram que o meio, por sua redundância, costuma ser mais robusto aos intempéries do que as organizações. Deste modo, ao agir contrariando a necessidade de 
homeostase do meio, as organizações podem assinar sua própria sentença de morte, uma vez que sob esta concepção, os sistemas que não estabelecem uma relação de autoregulação com o meio autopoiético que os cercam, acabam sendo eliminados do sistema de ordem maior. Neste sentido, Lenton (1998) constatou que estes grandes sistemas híbridos, como "Gaia", precisam de um equilíbrio saudável entre cooperação e competição, onde o ideal á que estas atividades contribuam para a manutenção dos ritmos dos sistemas de ordem superior, pois esta conservação do equilíbrio do ambiente externo é que auxilia na manutenção da própria sobrevivência dos subsistemas, nele inseridos. - ver capítulo 5.4.1.

Ao extrapolar tal constatação para o âmbito das organizações é possível considerar que o mesmo tipo de equilíbrio é necessário entre a organização e os dois principais sistemas que a cercam - o sócio-sistema humano e o sistema de "Gaia". Sob esta perspectiva a estratégia não pode mais ser vista apenas sob a ótica da vantagem competitiva, mas também sob a ótica da perpetuação, que depende, não só da competição, como também do tipo de relação simbiótica que a organização nutre com os demais elementos dos sistemas maiores dos quais faz parte.

Portanto, a ideia de cooperação que emerge desta condição, vai além aquela adotada pelas perspectivas contemporâneas das organizações em redes, como os clusters e os arranjos produtivos locais. Neste contexto, a cooperação não deve se desenvolver exclusivamente entre organizações, ou entre colaboradores e organizações. Para garantir a sustentabilidade dos sistemas, é fundamental que haja cooperação das organizações com o próprio ambiente que as rodeiam.

Neste sentido, há de se destacar que Aktouf (1996, p. 112) fez a preocupante constatação de que "crescer e auferir maiores lucros se faz ao preço de maior degradação da natureza e da qualidade de vida." Neste contexto, as decisões estratégicas das organizações não podem mais se basear na ideia de apropriação de valor. Ao buscar sua sobrevivência no longo prazo, elas precisam se fundamentar nos ideais de simbiose com a sociedade e também com o próprio planeta.

Ao se somar os benefícios e danos causados em qualquer processo realizado pelas organizações - tanto à sociedade quanto ao meio ambiente - a preocupação dos tomadores de decisão deve ser direcionada ao saldo do processo, não no sentido financeiro e sim em um sentido de impactos diretos na sobrevivência e na dinâmica dos sistemas de ordem maior. Em outras palavras, os tomadores de decisão devem abordar o problema da 
estratégia, assim como os organismos vivos o fazem na natureza. Devem Sustentar certo nível de competição, mas acima de tudo, devem reconhecer o papel da organização como um simbionte extremamente íntimo e dependente destes sistemas. Neste sentido, Aktouf (1996) defende que a solução para os danos causados pelas organizações, aos sistemas de ordem maior, podem ser evitados por meio de um crescimento equilibrado onde são respeitados "[...] o ritmo da renovação dos recursos e da energia e, sobretudo, as condições de "boa saúde" dos seres humanos e da natureza." (AKTOUF, 1996, p. 112)

Devido à sensibilidade às condições iniciais dos sistemas que compõem o meio ambiente, este cenário também coloca a estratégia em um cenário de intensa complexidade. Esta situação apresenta sérias implicações sobre os ideais de controle estratégico previsto pelas escolas prescritivas, já que seu enfoque normalmente se concentra na previsibilidade das interações externas à organização - ver capítulo 3.2.

Neste sentido, Levy (1994) propõe que a única forma de otimizar as previsões de futuro é por meio da adoção das técnicas de simulações de curto prazo, baseadas em modelos cuidadosamente elaborados, assim como é feito pelos meteorologistas, ao prever os complexos e caóticos sistemas climáticos. Matthews (2008) destaca que neste tipo de simulação, feita em modelos climáticos, a modelagem não só é extremamente cuidadosa, como as simulações são realizadas diversas vezes, com pequenas variações nos dados de entrada, para verificar as probabilidades de sucesso das previsões no prazo indicado. Contudo, a própria essência do caos determina que mesmo estes sofisticados sistemas, contribuem apenas para previsões e planejamentos em ciclos de curto prazo, cuja probabilidade de sucesso preditivo decai com o passar do tempo - ver capítulo 5.2.

Desse modo, este tipo de simulação é limitado por horizontes temporais restritos e sujeitos a probabilidades de sucesso preditivo, que muitas vezes tornam seu uso pouco útil. Neste sentido, os estudos realizados pelas ciências da natureza mostram que, para ter sucesso no longo prazo, os sistemas devem cultivar a diversificação de nichos de organizações e da conjunção de organizações, tendo em vista a manutenção da dinâmica de "Gaia" e do sócio-sistema humano. As simulações realizadas por Watson e Lovelock (1983) e por Lenton (1998; 2001) mostram que se as organizações produzirem laços de realimentação com os sistemas que compõem o meio, capazes de auxiliar na regulação do mesmo, elas podem contribuir para a manutenção de seu sensível componente autopoiético. Quando associadas por analogia com as condições sociais, as simulações dos 
autores mostram que a desestabilização do ecossistema, assim como as rupturas socioeconômicas, podem levar ao colapso da própria máquina autopoiética que compõe o programa da organização inutilizando-a.

Neste ponto é importante ressaltar que por melhor que sejam os cuidados das organizações com o ambiente que as cercam, o envelhecimento dos sistemas, conforme proposto por Prigogine (2002), os leva em direção ao equilíbrio termodinâmico. Portanto é necessário ter claro que o meio ambiente está sendo vítima da entropia, ou seja, está se deteriorando gradualmente - ver capítulo 5.2. Mesmo com esforços corretivos a autoorganização do meio representa um comportamento estável apenas em um conjunto de intervalos, no qual o caos reina sobre a entropia, conforme descritos por Vilar e Rubí (2001) e Reguera, Rubí e Vilar (2005) - ver capítulo 5.2.

Uma vez que as organizações se reinventam às custas da entropia do atual sistema econômico e social e este sistema está envelhecendo, haverá um momento onde a disponibilidade de entropia negativa no ambiente será insuficiente para sustentar determinadas configurações. Dessa forma, será necessário um novo modelo organizacional e social para se adaptar a este novo ambiente, cada vez mais homogêneo e próximo do equilíbrio.

Logo, existe um intervalo de tempo máximo, onde nossa estrutura econômica e social atual conseguirá perdurar, após o qual, apenas as organizações que conseguirem se reinventar, para atingirem uma menor dependência de ordem externa, é que poderão sobreviver. No limite, este cenário desalentador mostra que as organizações precisam encarar a possibilidade de que por melhor que ajam seus tomadores de decisão, um dia estas chegarão ao fim. Portanto, a concepção da estratégia simbiótica reconhece que o que está ao alcance da máquina autopoiética da organização - ou seja, de sua estratégia - não é a sua perpetuação infinita e sim a possibilidade de extensão de sua existência. 



\section{CONSIDERAÇÕES FINAIS}

No decorrer deste esforço de pesquisa foi desenvolvida uma concepção onde os acoplamentos íntimos entre as organizações, os seres humanos e o ambiente se constituem nas variáveis fundamentais para a descrição dinâmica dos aspectos internos e externos da organização. Em um mundo de acoplamentos, como o descrito, as organizações humanas surgem em meio à complementaridade com o meio que as cercam. Esta concepção da dinâmica das organizações, como um processo simbiótico, traz uma perspectiva na qual as organizações humanas, os sistemas sociais e o planeta, atuam como grandes organismos vivos, indispensavelmente interligados, dotados de suas particularidades e individualidades.

Tal ponto de vista possibilita que cada parte da organização seja tratada mediante sua própria dinâmica de funcionamento, conforme proposto pelas abordagens clássicas, ao mesmo tempo em que ressalta a importância dos acoplamentos da organização com os sistemas de ordem maior dos quais esta faz parte. Diante disso, a teoria de "Gaia" ilustra que é importante que o estrategista perturbe internamente a cultura para que o programa da organização entre em um laço de realimentação construtivo, tanto com o sistema planetário, como com o sócio-sistema humano.

Somente por meio de laços cooperativos é que as organizações regidas por tal dinâmica podem garantir a estabilidade de seu "ecossistema" e, por assim dizer, sua própria sobrevivência ao longo do tempo. Conforme lembra Drucker (2000) as organizações contemporâneas precisam garantir sua sobrevivência no longo prazo para que a grande massa de seus investidores chegue à sua aposentadoria. Com base nesta concepção, as abordagens clássicas não se sustentam em uma dinâmica como a encontrada nestes sistemas, ao passo que a sobrevivência do meio no qual a organização se encontra inserida não é incluída como um componente relevante em tais modelos.

Entretanto, na concepção simbiótica da organização a lógica da estratégia deve ser aquela das respostas ordenadas para a manutenção e ajuste do meio, ou seja, deve ser uma lógica proativa, onde as organizações reconhecem seu impacto sobre o meio como um todo e atuam de forma ordenada para reduzir sua degeneração. Portanto, as organizações 
precisam reconhecer que estas afetam as dinâmicas do ambiente externo que, por sua vez, afeta a própria organização. A organização é, portanto, responsável, em parte, pela evolução e o estado do meio externo, assim como este é responsável pela formação do comportamento da organização.

Ao se reconhecer as associações das organizações com os sistemas que às cercam como um processo simbiótico, onde a sobrevivência de ambos se encontram correlacionadas, a estratégia não pode se pautar exclusivamente pela competição, mas também em um ideal de cooperação na auto-regulação de sistemas conjugados que, em última instância, difere de maneira significativa dos modelos estratégicos clássicos, baseados na competição e na maximização de valor individual. Desse modo, a concepção simbiótica dos aspectos internos e externos do problema estratégico, implica na necessidade de uma nova concepção de organização, baseada em uma abordagem cooperativa, onde a visão individual é substituída por uma visão social e ambiental.

Uma vez que a tendência natural das organizações contemporâneas é a da acumulação, as organizações governamentais assumem um papel fundamental como agregadoras das organizações privadas e como anticorpos do sócio-sistema humano. Isso porque, a ruptura de tais princípios requer a regulação de uma entidade capaz de desintegrar ou extinguir aqueles tipos de organização que não forem sinérgicas com o objetivo de garantir a sobrevivência dos sistemas de ordem maior dos quais fazem parte. Da mesma forma, as organizações privadas e os indivíduos também podem assumir um papel de reguladores dos governos, reduzindo as probabilidades destes assumirem dinâmicas governamentais que contrariem esta mesma lógica que deveriam defender.

Diante de uma perspectiva simbiótica a lógica da estratégia também não deve ser uma lógica onde se procura antecipar o futuro em busca de uma posição que coloque a organização à frente da concorrência. Diante desta concepção, além das previsões de longo prazo estarem se tornando cada vez mais infrutíferas, esta busca pode levar a rupturas desenfreadas da própria estrutura do meio. Uma vez que a estratégia emerge como um programa autopoiético na organização, a ontogenia destes sistemas pode não ser suficientemente rápida para acompanhar as rupturas provocadas pela própria organização, levando-a a sucumbir.

A teoria dos sistemas dissipativos mostra que os novos cenários continuarão a surgir e se complementar, em decorrência do aumento da entropia do meio. Mas é importante 
para uma organização que pretende se perpetuar, que a deterioração do meio ocorra em um ritmo tal que permita a ela se adaptar. Neste contexto, a adoção de uma postura de agente participativo da homeostase do meio, por parte das organizações, se mostra fundamental para garantir a estabilidade do meio que as cercam, durante os períodos de adaptação. Caso esta necessidade seja negligenciada pode levar o meio a se deteriorar em uma taxa maior do que a capacidade de adaptação das organizações pode absorver, desintegrando-as.

Com a redução dos recursos disponíveis também podem ocorrer colapsos sistêmicos. Neste sentido, os indivíduos assumem um papel crucial para a sobrevivência das organizações. Eles estão inseridos ao mesmo tempo no conjunto das organizações e da sociedade, realizando continuamente o fluxo de energia, matéria e informação na organização. Em condições de instabilidade e escassez de recursos, a variedade interna e a redundância precisam ser cultivadas. Destarte, adquirir novos "materiais genéticos corporativos" é fundamental para uma estratégia baseada no conceito de empresa simbiótica.

Por fim este trabalho conclui que, apesar de ir de encontro com as abordagens exclusivamente competitivas, este ponto de vista não nega ou substitui nenhuma das cinco visões anteriores acerca da estratégia, já que, em última análise, todas as perspectivas anteriores se constituem em mecanismos ou descrições que direcionam as organizações para acoplamentos. Portanto, a ideia central de Mintzberg, Ahlstrand e Lampel (1998) está de acordo com a percepção simbiótica dos aspectos internos e externos da organização, já que os pontos de vista já explorados pelos estudiosos da área compõem, de fato, partes de um processo maior. Contudo, é importante ressaltar que dinâmica simbiótica exige uma expansão do escopo da estratégia, de forma que seu foco interno e externo também inclua os demais simbiontes dos sofisticados sistemas com os quais estas se acoplam em diversos níveis. Diante de uma abordagem coletiva desta postura simbiótica, se torna possível vislumbrar a construção de um sistema onde as organizações se integrem de forma social e ambientalmente sustentável. 



\section{REFERÊNCIAS}

AKTOUF, O. A administração entre a tradição e a renovação. Tradução de CUNHA, A. J.; MAZZILLI, C.; ANTUNES, E. D. D.; DANTAS, M.; FACHIN, R. C.; FISCHER, T. São Paulo: Atlas, 1996.

ALENCAR, C. Rebeldes com causa. In: ALENCAR, C. (Ed.). Manifesto Comunista. Rio de Janeiro: Garamond, 2001. Cap.1. p. 7-35.

ALMEIDA, M. I. R. D. Manual de planejamento estratégico: desenvolvimento de um plano estratégico com a utilização de planílhas excel. São Paulo: Atlas, 2001.

ANDERY, M. A.; MICHELETTO, N.; SÉRIO, T. M. P.; RUBANO, D. R.; MOROZ, M.; PEREIRA, M. E.; GIOIA, S. C.; GIANFALDONI, M.; SAVIOLI, M. R.; ZANOTTO, M. D. L. Para compreender a ciência: uma perspectiva histórica. 7. ed. São Paulo, Rio de Janeiro: Educ, 1996.

ANDREWS, K. R. The concept of corporate strategy. In: MINTZBERG, H.; LAMPEL, J.; QUINN, J. B.; GHOSHAL, S. (Ed.). The strategy process: concepts, contexts, cases. Upper Saddle River: Pearson, 2003. Cap.3.1. p. 72-79.

ANSOFF, H. I.; DECLERCK, R. P.; HAYES, R. L. Do planejamento estratégico à administração estratégica. In: ANSOFF, H. I.; DECLERCK, R. P.; HAYES, R. L. (Ed.). Do planejamento estratégico à administração estratégica. São Paulo: Atlas, 1981. Cap.Transformação da atitude estratégica. p. 48-90.

ANSOFF, H. I.; HAYES, R. L. Evolução do problema estratégico. In: ANSOFF, H. I.; DECLERCK, R. P.; HAYES, R. L. (Ed.). Do planejamento estratégico à administração estratégica. São Paulo: Atlas, 1981. Cap.Introdução. p. 15-18.

ASHBY, W. R. Introdução à cibernética. Tradução de GUINSBURG, G. K. São Paulo: Perspectiva, 1970. (Estudos).

ATLAN, H. On a formal definition of organization. Journal of Theoretical Biology, v. 45, p. 295-304, 1974.

As finalidades inconscientes. In: THOMPSON, W. I. (Ed.). Gaia: uma teoria do conhecimento. São Paulo: Gaia, 2001. Cap.6. p. 103-119. 
BACHELARD, G. Le nouvel esprit scientifique. 13. ed. Paris: Presses Universitaires de France, 1975.

. Epistemologia: trechos escolhidos. Tradução de CAIXEIRO, N. C. 2. ed. Rio de Janeiro: Zahar, 1983.

BAPTISTA, M. N.; CAMPOS, D. C. D. Metodologia de pesquisa em ciências: análises quantitativa e qualitativa. Rio de Janeiro: LTC, 2007.

BATEMAN, T. S.; SNELL, S. A. Administração: construindo vantagem competitiva. Tradução de RIMOLI, C. A. São Paulo: Atlas, 1998.

Administração: novo cenário competitivo. Tradução de BAZÁN, T. E. L. L. 2. ed. São Paulo: Atlas, 2006.

BATESON, G. Cybernetic explanation. The american behavioral scientist, v. 10, n. 8, p. 29-32, Apr. 1967.

BAUER, R. Gestão da mudança: caos e complexidade nas organizações. São Paulo: Atlas, 1999.

BEINHOCKER, E. D. Estratégias adaptativas consistentes. In: CUSUMANO, M. A.; MARKIDES, C. C. (Ed.). Pensamento Estratégico. Rio de Janeiro: Campus, 2002. Cap.6. p. 133-155.

BEREAU OF LABOR STATISTICS. Economic news release: selected unemployment indicators, seasonally adjusted. United states department of labor, 2009.

BERTALANFFY, L. V. Teoria geral dos sistemas: fundamentos desenvolvimento e aplicações. Tradução de GUIMARÃES, F. M. 4. ed. Petrópolis: Vozes, 2009.

BERTERO, C. O.; CALDAS, M. P.; WOOD JR., T. Produção Científica em Administração de Empresas: Provocações, Insinuações e Contribuições para um Debate Local. Revista de Administração Contemporânea, v. 3, n. 1, p. 147-178, Jan./Abr. 1999. 
BETHLEM, A. Estratégia empresarial: conceitos, processos e administração estratégica. 3. ed. São Paulo: Atlas, 2001.

$\mathrm{BOHR}, \mathrm{N}$. The quantum postulate and the recent development of atomic theory. Nature, $\mathrm{v}$. 121, p. 580-591, Jan-Jun. 1928.

Can quantum-mechanical description of physical reality be considered complete. Physical Review, v. 48, p. 696-702,15. out. 1935.

BRITT, C. L. Reconsidering the unemployment and crime relationship: variation by age group and historical period. Journal of quantitative criminology, v. 13, n. 4, p. 405-428, 1997.

BUNGE, M. Epistemologia: curso de atualização. Tradução de NAVARRA, C. 2. ed. São Paulo: T. A. Queiroz: Editora da Universidade de São Paulo, 1987.

BURGELMAN, R. A.; GROVE, A. S. Let chaos reign, then rein in chaos-repeatedly: Managing strategic dynamics for corporate longevity. Strategic Management Journal, v. 28, n. 10, p. 965-979, Oct 2007.

CAPRA, F. The turning point: science, society, and the rising culture. Toronto; New York: Bantam Books, 1983.

A teia da vida: uma nova compreensão científica dos sistemas vivos. Tradução de EICHEMBERG, N. R. São Paulo: Cultrix, 2006.

CARAVANTES, G. R.; PANNO, C. C.; KLOECKNER, M. C. Administração: teorias e processos. São Paulo: Prentice Hall, 2005.

CASANOVA, P. G. As novas ciências e as humanidades: da academia à política. Tradução de BENEDITO, M. 1. ed. São Paulo: Boitempo, 2006.

CERVO, A. L.; BERVIAN, A. Metodologia científica. 5. ed. São Paulo: Prentice Hall, 2002.

CHIBENI, S. S. Certezas e incertezas sobre as relações de Heisenberg. Revista Brasileira de Ensino de Física, v. 27, n. 2, p. 181-192, 2005. 
CLEGG, S.; CARTER, C.; KORNBERGER, M. Get up, I feel like a strategy machine. European Management Review, v. 1, n. 1, p. 21-28, 2004.

COOPER, D. R.; SCHINDLER, P. S. Métodos de pesquisa em administração. Tradução de ROCHA, L. D. O. D. 7. ed. Porto Alegre: Bookman, 2003.

COPLESTON, F. A history of philosophy. New York, London, Toronto, Sydney, Auckland: Doubleday, 1993.

CREMA, R. Introdução à visão holística: breve relato de viagem do velho ao novo paradigma. 5. ed. São Paulo: Summus, 1989.

CROMBIE, A. C. Theory \& Experiment in the Science of Robert Grosseteste [Abstract]. Bulletin of the British Society for the History of Science, v. 1, n. 4, p. 86, 1950.

DELL'ARICCIA, G.; IGAN, D.; LAEVEN, L. The relationship between the recent boom and the current delinquencies in subprime mortgages. In: FELTON, A.; REINHART, C. (Ed.). The first global financial crisis of the 21st century. London: VoxEU.org, 2008.

DESCARTES, R. Regras para a orientação do espírito. Tradução de GALVÃO, M. E. D. A. P. 2. ed. São Paulo: Martins Fontes, 2007. (Clássicos).

DEVLIN, K. Good-bye Descartes? Mathematics Magazine, v. 69, n. 5, p. 344-349, Dec. 1996.

DRUCKER, P. F. The age of social transformation. The atlantic monthly, v. 274, n. 5, p. 53-80, Nov. 1994.

Administrando para obter resultados. Tradução de MONTINGELLI JR., N. São Paulo: Pioneira, 1998.

1999.

. The discipline of innovation. Fund Raising Management, v. 30, n. 3, p. 34-35, May.

. Strategies for the 21 st century. Tooling \& Production, v. 66, n. 1, p. 92-97, Apr. 2000. 
The new realities. Revised. ed. New Brunswick: Transaction Publishers, 2003.

FACHIN, O. Fundamentos de metodologia. 3. ed. São Paulo: Saraiva, 2001.

FARIA, A. Realismo crítico em pesquisa estratégica. In: VIEIRA, M. M. F.; ZOUAIN, D. M. (Ed.). Pesquisa qualitativa em administração. Rio de Janeiro: Editora FGV, 2005. p. 45-69.

FEYNMAN, R. P.; LEIGHTON, R. B.; SANDS, M. Quantum mechanics. Menlo Park: AddisonWesley, 1966. (Lectures on physics).

FINEMAN, S. Unemployment: personal and social consequences. London; New York: Routledge, 1987.

GAUKROGER, S. Descartes: methodology. In: R.PARKINSON, G. H. (Ed.). The renaissance and seventeenth-century rationalism. London: Routledge, 2005. Cap.5. p. 156-186. (Routledge history of philosophy).

GENTNER, D.; BOWDLE, B.; WOLFF, P.; BORONAT, C. B. Metaphor is like analogy. In: GENTNER, D.; HOLYOAK, K. J.; KOKINOV, B. N. (Ed.). The analogical mind: perspectives from cognitive science: The MIT Press, 2001. Cap.6. p. 199-254. (Bradford Books).

GHEMAWAT, P. A estratégia e o cenário dos negócios: textos e casos. Tradução de MONTINGELLI JR., N. Porto Alegre: Bookman, 2000.

GHOSHAL, S.; BERTLETT, C. A.; MORAN, P. Um novo manifesto pela gerência. In: CUSUMANO, M. A.; MARKIDES, C. C. (Ed.). Pensamento Estratégico. Rio de Janeiro: Campus, 2002. Cap.1. p. 17-39.

GIBSON, J. L.; IVANCEVICH, J. M.; DONNELLY JR., J. H.; KONOPASKE, R. Organizações: comportamento, estrutura e processos. Tradução de SONOE, S.; CUCCIO, M. 12. ed. São Paulo: MacGraw-Hill, 2006.

GILES, T. R. História do existencialismo e da fenomenologia. São Paulo: EPU, 1989. 
GLASS, L.; MACKEY, M. C. Dos relógios ao caos: os ritmos da vida. Tradução de BARANAUSKAS, V.; FRAGOSO, C. São Paulo: Editora da Universidade de São Paulo, 1997.

GLEICK, J. Chaos: making a new science. New York: Penguin Books, 1988.

GLEISER, M. Criação imperfeita: cosmo, vida e o código oculto da natureza. São Paulo: Record, 2010.

GOLDENBERG, M. A arte de pesquisar: como fazer pesquisa qualitativa em ciências sociais. 10. ed. Rio de Janeiro: Record, 2007.

GOULIELMOS, A. M. Complexity theory: a science where historical accidents matter. Disaster Prevention and Management, v. 14, n. 4, p. 533-547, 2005.

HAMEL, G. Strategy as revolution. Harvard Business Review, v. 74, n. 4, p. 69-82, 1996.

. Strategy emergence. Executive Excellence, v. 15, n. 12, p. 3-4, 1998.

. Inovação estratégica e busca do valor. In: CUSUMANO, M. A.; MARKIDES, C. C. (Ed.). Pensamento Estratégico. Rio de Janeiro: Campus, 2002. Cap.8. p. 181-195.

HASELHOFF, F. Novo paradigma para o estudo das metas organizacionais. In: ANSOFF, H. I.; DECLERCK, R. P.; HAYES, R. L. (Ed.). Do planejamento estratégico à administração estratégica. São Paulo: Atlas, 1981. Cap.1. p. 28-40.

HAWKING, S. Uma breve história do tempo: do Big Bang aos buracos negros. Tradução de TORRES, M. H. Rio de Janeiro: Rocco, 1988.

. The universe in a nutshell. London: Bantam Press, 2001.

HEGEL, G. W. F. Fenomenologia do espírito. Tradução de MENESES, P. 4. ed.: Vozes, 1999. (Pensamento humano).

HEYLIGHEN, F. Principles of Systems and Cybernetics: an evolutionary perspective. Cybernetics and Systems '92. 1992. p.3-10. 
HITT, M. A.; IRELAND, R. D.; HOSKISSON, R. E. Administração estratégica: competitividade e globalização. Tradução de SANTOS, J. C. B. D.; RAFAEL, L. A. P. São Paulo: Pioneira Thomson Learning, 2003.

HUNGER, J. D.; WHEELEN, T. L. Gestão estratégica: princípios e prática. Tradução de BAZÁN, T. E. L. L. 2. ed. Rio de Janeiro: Reichmann \& Affonso Editores, 2002.

HURTADO, P. Will the real complexity in strategic management please stand up? Competition Forum, v. 4, n. 1, p. 175-182, 2006.

HUSSERL, E. Meditações cartesianas: introdução à fenomenologia. Tradução de OLIVEIRA, F. D. São Paulo: Madras, 2001.

HUSSEY, E. Pythagoreans and Eleatics. In: TAYLOR, C. C. W. (Ed.). From the beginning to plato. London: Routledge, 2005. Cap.4. p. 117-160. (Routledge history of philosophy).

INTERNATIONAL MONETARY FUND. Global financial stability report: responding to the financial crisis and measuring systemic risk. International Monetary Fund. Washington. 2009. p.222, Abr. 2009.

JAAFARI, A. Project Management in the age of complexity and change. Project management journal, v. 34, n. 4, p. 47-57, Dez. 2003.

JASPERS, K. Introdução ao pensamento filosófico. 3. ed. São Paulo: Cultrix, 1976.

JUNG, C. Psychological types. Princeton: Princeton University Press, 1971. (Collected works).

KAPLAN, R. S.; NORTON, D. P. A estratégia em ação: balanced scorecard. Tradução de FRAZÃO FILHO, L. E. T. 13. ed. Rio de Janeiro: Campus, 1997.

KHANNA, T. Foundations of neural networks. Menlo Park: Addison-Wesley Publishing Company, 1990.

KONDER, L. O que é dialética. 21. ed. São Paulo: Brasiliense, 1990. 
KUHN, T. S. The structure of scientific revolutions. 3. ed. Chicago: The University of Chicago Press, 1996.

LAPLACE, M. D. Essai philosophique sur les probabilités. Bruxelles: Chez H. Remy, 1829.

LENTON, T. M. Gaia and natural selection. Nature, v. 394, n. 30, p. 439-447, Jul. 1998.

LENTON, T. M.; LOVELOCK, J. Daisyworld revisited: quantifying biological effects on planetary self-regulation. Tellus B, v. 53, n. 3, p. 288-305, 2001.

LETHBRIDGE, T. Para que servem os analistas? Revista Exame. n. 23. São Paulo: Editora Abril, 2008. p. 20-29.

LEVY, D. Chaos theory and strategy: theory, application, and managerial implications. Strategic Management Journal, v. 15, p. 167-178, 1994.

LIMA, T. C. S. D.; MIOTO, R. C. T. Procedimentos metodológicos na construção do conhecimento científico: a pesquisa bibliográfica. Revista Katálysis, v. 10, n. esp, p. 37-45, 2007.

LOBATO, D. M.; MOYSÉS FILHO, J.; TORRES, M. C. S.; RODRIGUES, M. R. A. Estratégia de empresas. 8. ed. Rio de Janeiro: FGV, 2007. (Gestão Empresarial).

LOVELOCK, J. Gaia: a new look at life on earth. Oxford: Oxford University Press, 2000.

. Gaia: um modelo para a dinâmica planetária e celular. In: THOMPSON, W. I. (Ed.). Gaia: uma teoria do conhecimento. São Paulo: Gaia, 2001. Cap.4. p. 77-90.

LUHMANN, N. Social Systems. Tradução de BEDNARZ JR., J. Stanford: Stanford University Press, 1995.

MARGULIS, L. Symbiotic planet: a new look at evolution. New York: Basic Books, 1998. 
. Os primórdios da vida: os micróbios têm prioridade. In: THOMPSON, W. I. (Ed.). Gaia: uma teoria do conhecimento. São Paulo: Gaia, 2001. Cap.5. p. 91-101.

MARGULIS, L.; SAGAN, D. Microcosmos: four billion years of evolution from microbial ancestors. London Allen \& Unwin, 1987.

O que é vida? Tradução de RIBEIRO, V. Rio de Janeiro: Jorge Zahar, 2002.

MARKIDES, C. C. Uma visão dinâmica da estratégia. In: CUSUMANO, M. A.; MARKIDES, C. C. (Ed.). Pensamento Estratégico. Rio de Janeiro: Campus, 2002. Cap.10. p. 227-244.

MARRONE, S. Metaphysics and science in the thirteenth century: William of Auvergne, Robert Grosseteste and Roger Bacon. In: MARENBON, J. (Ed.). Medieval philosophy. London: Routledge, 2004. Cap.9. p. 204-224. (Routledge history of philosophy).

MARX, K.; ENGELS, F. Manifesto do Partido Comunista. In: ALENCAR, C. (Ed.). Manifesto Comunista. Rio de Janeiro: Garamond, 2001. Cap.2. p. 37-88.

MATTHEWS, R. 25 grandes idéias: como a ciência está transformando nosso mundo. Tradução de GRADEL, J. Rio de Janeiro: Jorge Zahar, 2008.

MATURANA, H. R.; VARELA, F. J. The tree of knowledge: the biological roots of human understanding. Tradução de PAOLUCCI, R. Boston: New Science Library, 1988.

De máquinas e seres vivos: autopoiese - a organização do vivo. Tradução de LLORENS, J. A. 3. ed. Porto Alegre: Artmed, 1997.

MERLEAU-PONTY, M. Fenomenologia da percepção. Tradução de DE MOURA, C. A. R. 2. ed. São Paulo: Martins Fontes, 1999.

MILLER, R. W. Fact and Method: Explanation, Confirmation and Reality in the Natural and the Social. New Jersey: Princeton University Press, 1987.

MINTZBERG, H. Crafting strategy. Harvard Business Review, v. 65, n. 5, p. 66-75, 1987a. 
. The strategy concept I: five ps for strategy. California Management Review, v. 30, n. 1, p. 11-24, 1987b.

. Crafting strategy. In: MINTZBERG, H.; LAMPEL, J.; QUINN, J. B.; GHOSHAL, S. (Ed.). The strategy process: concepts, contexts, cases. Upper Saddle River: Pearson, 2003a. Cap.5.1. p. 141-149.

. Five Ps for strategy. In: MINTZBERG, H.; LAMPEL, J.; QUINN, J. B.; GHOSHAL, S. (Ed.). The strategy process: concepts, contexts, cases. Upper Saddle River: Pearson, 2003b. Cap.1.1. p. 3-9.

. Generic strategies. In: MINTZBERG, H.; LAMPEL, J.; QUINN, J. B.; GHOSHAL, S. (Ed.). The strategy process: concepts, contexts, cases. Upper Saddle River: Pearson, 2003c. Cap.4.5. p. 115-127.

MINTZBERG, H.; AHLSTRAND, B.; LAMPEL, J. Strategy safari: a guided tour through the wilds of strategic management. New York: The Free Press, 1998.

MINTZBERG, H.; LAMPEL, J. Reflecting on the strategy process. Sloan Management Review, v. 40, n. 3, p. 21-30, 1999.

MOREIRA, D. A. O método fenomenológico na pesquisa. São Paulo: Pioneira Thomson, 2002.

MORIN, E. Ciência com consciência. Tradução de ALEXANDRE, M. D.; DÓRIA, M. A. S. 10. ed. Rio de Janeiro: Bertrand, 2007a.

- Educação e complexidade: os sete saberes e outros ensaios. Tradução de CARVALHO, E. D. A. 4. ed. São Paulo: Cortez, 2007b.

Introdução ao pensamento complexo. Tradução de LISBOA, E. 3. ed. Porto Alegre: Sulina, 2007c.

NAGEL, E. The structure of science: problems in the logic of scientific explanation. 2. ed. Indianapolis: Hackett Publishing, 1979. 
NEWTON, S. I. The mathematical principles of natural philosophy. Tradução de MOTTE, A. 1. ed. New York: Daniel Adee, 1846.

NOWOTNY, $\mathrm{H}$. The increase of complexity and its reduction: emergent interfaces between the natural sciences, humanities and social sciences. Theory culture society, v. 22, n. 5 , p. 15-31, Oct. 2005.

OSBORNE, C. Heraclitus. In: TAYLOR, C. C. W. (Ed.). From the beginning to plato. London: Routledge, 2005. Cap.3. p. 80-116. (Routledge history of philosophy).

OSTERMANN, F.; PRADO, S. D. Interpretações da mecânica quântica em um interferômetro virtual de Mach-Zehnder. Revista Brasileira de Ensino de Física, v. 27, p. 193-203, 2005.

PARRA FILHO, D.; SANTOS, J. A. Metodologia científica. 5. ed. São Paulo: Futura, 2002.

PASCALE, R. T. Surfando à beira do caos. In: CUSUMANO, M. A.; MARKIDES, C. C. (Ed.). Pensamento Estratégico. Rio de Janeiro: Campus, 2002. Cap.5. p. 111-132.

PETERS, T. Prosperando no caos. Tradução de MONTINGELLI, N. São Paulo: Harbra, 1989.

PIERCE, J. R. An introduction to information theory: symbols, signals and noise. 2. ed. New York: Dover Publications, 1980.

PORTER, M. E. Vantagem competitiva: criando e sustentando um desempenho superior. Tradução de PINHO, E. M. D. Rio de Janeiro: Campus, 1990.

. What is strategy? Harvard Business Review, v. 74, n. 6, p. 61-78, 1996.

Estratégia competitiva: técnicas para análise de industrias e da concorrência. Tradução de BRAGA, E. M. D. P. 17. ed. Rio de Janeiro: Campus, 1999.

PRAHALAD, C. K.; HAMEL, G. Strategy as a field of study: why search for a new paradigm? Strategic Management Journal, v. 15, p. 5-16, 1994. 
PRIGOGINE, I. O fim das certezas: tempo, caos e as leis da natureza. Tradução de FERREIRA, R. L. São Paulo: UNESP, 1996. (Biblioteca básica).

. As leis do caos. Tradução de FERREIRA, R. L. São Paulo: UNESP, 2002.

PRINCIPE, J. C.; EULIANO, N. R.; LEFEBVRE, W. C. Neural and adaptive systems: fundamentals through simulations. New York: John Wiley \& Sons, Inc., 1999.

QUINN, J. B. Strategies for change. In: MINTZBERG, H.; LAMPEL, J.; QUINN, J. B.; GHOSHAL, S. (Ed.). The strategy process: concepts, contexts, cases. Upper Saddle River: Pearson, 2003. Cap.1.2. p. 10-16.

REGUERA, D.; RUBÍ, J. M.; VILAR, J. M. G. The mesoscopic dynamics of thermodynamic systems. Journal of Physical Chemistry B, v. 109, n. 46, p. 21502-21515, 2005.

RIBEIRO JR., J. O que é positivismo. 11. ed. São Paulo: Brasiliense, 1982.

SACHS, J. D. Cuidando do futuro. Scientific American Brasil, n. 79, p. 23, 2008.

SAGAN, C. O mundo assombrado pelos demônios: a ciência vista como uma vela no escuro. Tradução de EICHEMBERG, R. São Paulo: Companhia das Letras, 2006.

SARDAR, Z.; ABRAMS, I. Introducing chaos. Duxford: Icon Books, 1999.

SENGE, P. M. A quinta disciplina: arte e prática da organização que aprende. Tradução de ZIDE NETO, G. 25. ed. Rio de Janeiro: BestSeller, 2009.

SENGE, P. M.; SCHARMER, C. O.; JAWORSKI, J.; FLOWERS, B. S. Alternative Future. Leadership Excellence, v. 25, n. 2, p. 3-4, 2008.

SHANNON, C. E. A mathematical theory of communication. The bell system technical journal, v. 27, p. 379-423, 623-656, 1948. 
SKÅR, J. Introduction: self-organization as an actual theme. Philosophical Transactions of the Royal Society a-Mathematical Physical and Engineering Sciences, v. 361, n. 1807, p. 1049-1056, 2003.

SPINELLI, M. Filósofos pré-socráticos: primeiros mestres da filosofia e da ciência grega. 2. ed. Porto Alegre: Edipucrs, 2003. (Filosofia - 81).

STACEY, R. D. THE SCIENCE OF COMPLEXITY - AN ALTERNATIVE PERSPECTIVE FOR STRATEGIC CHANGE PROCESSES. Strategic Management Journal, v. 16, n. 6, p. 477-495, Sep. 1995.

THIOLLENT, M. Problemas de metodologia. In: FlEURY, A. C. C.; VARGAS, N. (Ed.). Organização do trabalho: uma abordagem interdisciplinar: sete estudos sobre a realidade brasileira. São Paulo: Atlas, 1983. Cap.3. p. 54-83.

TZU, S. A arte da guerra. Tradução de SANZ, J. 12. ed. Rio de Janeiro: Record, 1983.

VALLE, A. B. D.; SOARES, C. A. P.; FINOCCHIO JR, J.; SILVA, L. D. S. F. D. Fundamentos do gerenciamento de projetos. Rio de Janeiro: Editora FGV, 2007. (Gerenciamento de projetos).

VARELA, F. J. Principles of Biological Autonomy. New York: Elsevier North Holland, 1979.

VARELA, F. J.; MATURANA, H. R.; URIBE, R. Autopoiesis: the organization of living systems, its characterization and a model. Biosystems, v. 5, n. 4, p. 187-196, May 1974.

VILAR, J. M. G.; RUBÍ, J. M. Thermodynamics "beyond" local equilibrium. Proceedings of the National Academy of Sciences of the United States of America, v. 98, n. 20, p. 11081-11084, 2001.

VITOUSEK, P. M. Beyond global warming: ecology and global change. Ecology, v. 75, n. 7, p. 1861-1876, 1994.

WATSON, A. J.; LOVELOCK, J. Biological homeostasis of the global environment: the parable of daisyworld. Tellus B, v. 35, n. 4, p. 284-289, 1983.

WHITTINGTON, R. Strategy after modernism: recovering practice. European Management Review, v. 1, n. 1, p. 62-68, 2004. 
WRIGHT, P.; KROLL, M. J.; PARNELL, J. Administração estratégica: conceitos. Tradução de RIMOLI, C. A.; ESTEVES, L. R. São Paulo: Atlas, 2007.

ZEY-FERRELL, M. Criticisms of the dominant perspective on organizations. The sociological quarterly, v. 22, n. 2, p. 181-205, 1981.

ZITKOSKI, J. J. $O$ método fenomenológico de Husserl. Porto Alegre: Edipucrs, 1994. (Filosofia - 12). 